\title{
Site U1387
}

\author{
Expedition 339 Scientists $^{2}$
}

\section{Chapter contents}

Background and objectives. . . . . . . 1

Operations...................

Lithostratigraphy.............4

Biostratigraphy ............... 13

Paleomagnetism ................ 18

Physical properties .............. 20

Geochemistry .................23

Downhole measurements............ 24

Stratigraphic correlation. . . . . . . . . 27

References.................. 28

Figures..................... 33

Tables.......................... 102

${ }^{1}$ Expedition 339 Scientists, 2013. Site U1387. In Stow, D.A.V., Hernández-Molina, F.J., Alvarez Zarikian, C.A., and the Expedition 339 Scientists, Proc. IODP, 339: Tokyo (Integrated Ocean Drilling Program Management International, Inc.). doi:10.2204/iodp.proc.339.105.2013

'Expedition 339 Scientists' addresses.

\section{Background and objectives}

Integrated Ocean Drilling Program (IODP) Site U1387, located toward the eastern end of Faro Drift $\left(36^{\circ} 48.3210^{\prime} \mathrm{N}, 7^{\circ} 43.1321^{\prime} \mathrm{W}\right)$, is one of the most important sites of Expedition 339 (Figs. F1, F4 in the "Site U1386" chapter [Expedition 339 Scientists, 2013c]). It represents an opportunity for recovering a key succession spanning the early Pleistocene, Pliocene, and latest Miocene. In particular, we are interested in the Pliocene record, which should allow us to determine the onset of the upper core of Mediterranean Outflow Water (MOW) and assess its influence on the margin during this period (Fig. F6 in the "Expedition 339 summary" chapter [Expedition 339 Scientists, 2013a]). Site U1387 is $\sim 4.1 \mathrm{~km}$ southeast of Site U1386 (Fig. F1 in the "Site U1386" chapter [Expedition 339 Scientists, 2013d] and F12 in the "Expedition 339 summary" chapter [Expedition 339 Scientists, 2013a]).

Opening of the Strait of Gibraltar (or Gibraltar Gateway) had a major impact on both the Alboran Sea and North Atlantic Ocean (Ryan et al., 1973; Duggen et al., 2003; Briand, 2008; García-Castellanos et al., 2009; Estrada et al., 2011; Garcia-Castellanos and Villaseñor, 2011). Opening of the Gibraltar Gateway is documented to have occurred at the end of the Miocene (Berggren and Hollister, 1974; Mulder and Parry, 1977; Maldonado et al., 1999; Estrada et al., 2011). One of its key effects was the initiation of MOW, the timing of which has generally been accepted as coeval with the Strait of Gibraltar opening (Maldonado and Nelson, 1999; Blanc, 2002; Khélifi et al., 2009).

Since the latest Miocene, an oblique compressional regime has regionally developed simultaneously with the extensional collapse of the Betic-Rif orogenic front by westward emplacement of a giant chaotic body known as the Cádiz Allochthonous Unit and by very high rates of basin subsidence coupled with strong diapiric activity (Maldonado et al., 1999; Medialdea et al., 2004, 2009; Zitellini et al., 2009). During the Pliocene and Quaternary, the effect of glacio-eustatic variations partly overprinted structural effects on the margin and resulted in erosion, sedimentary progradation, and incision of major submarine canyons (Mougenot, 1988; Llave et al., 2001, 2007a, 2011; Alves et al., 2003; Terrinha et al., 2003). By the end of the early Pliocene, subsidence decreased and the margin evolved toward its present, more stable conditions (Maldonado et al., 1999; Medialdea et al., 2004; Roque et al., 2012). Some neotectonic reactivation is also evident, as ex- 
pressed by the occurrence of mud volcanoes and diapiric ridges (Somoza et al., 2003; Fernández-Puga et al., 2007) and fault reactivation (Zitellini et al., 2009). Tectonics have represented a long-term key factor in affecting seafloor morphology, which has exerted strong control on the pathways of MOW and, therefore, on the architecture of the contourite depositional system (CDS) (Llave et al., 2007b, 2011; García et al., 2009; Roque et al., 2012).

Co-eval with the aforementioned tectonic framework, a very large CDS was generated during the Pliocene and Quaternary by the action of MOW on the middle slope of the Gulf of Cádiz. General background about this CDS as well as the Faro Drift was included in "Background and objectives" in the "Site U1386" chapter (Expedition 339 Scientists, 2013d).

Several authors have tried to reconstruct the Pliocene and Quaternary sedimentary stacking pattern and evolution of the large drifts within that CDS (Faugères et al., 1985; Nelson et al., 1999; Llave et al., 2001, 2007a, 2011; Hanquiez et al., 2007; Hernández-Molina et al., 2006, 2009; García et al., 2009; Marchès et al., 2007, 2010; Roque et al., 2012). They have proposed a contourite stacking pattern by different units and subunits depending very much on the resolution degree of their data set. Moreover, there is not a consensus between these authors about

- The timing of the onset of contourite deposition in the Faro-Albufeira Drift,

- The detail of evolutionary phases and specifically the nature of evolution during the early and late Pliocene,

- The age of the different seismic units, and

- The timing of neotectonic activity.

However, there is consensus about enhanced contourite deposition and marked drift growth during the Quaternary (i.e., after 2.6 Ma). Moreover, these authors have proposed two more phases of current intensification, possibly associated with the midPleistocene revolution (MPR; $\sim 0.9 \mathrm{Ma}$ ) and marine isotopic Stage $12(\sim 0.4 \mathrm{Ma})$, and inferred that the present drift morphology was developed after the MPR. In addition, most sediments within the drift were deposited by alongslope processes related to MOW, although some turbidite input and downslope processes were suggested by Riaza and Martinez del Olmo (1996), Maldonado et al. (1999), and Roque et al. (2012) for the early Pliocene and by Marchés et al. (2010) for the Quaternary.

\section{Objectives}

The major objective for Site U1387 was to recover a complete sedimentary record for at least the last 5.3 m.y. on the Faro Drift, deposited under the influence of the upper core of MOW.

This record will allow us to investigate

- The onset of MOW and its relation with the opening of the Gibraltar Gateway,

- The influence of the Gibraltar Gateway through the Pliocene,

- MOW paleoceanography and its global climate significance, and

- The effects of long- and short-term climate and sea level changes on the sediment architecture of the contourite drift.

Specific objectives for Site U1387 include:

- Drilling through the drift succession and into late Miocene sediments and hence dating the basal age of contourite drift sedimentation in the Gulf of Cádiz;

- Evaluating the nature of change in the patterns of sedimentation and microfauna from the end of the Miocene through the early to middle Pliocene;

- Documenting the possible effects of the Gibraltar Gateway through the Pliocene and hence determining the input variation of the influx of warm, saline intermediate water into the North Atlantic Ocean and the nature of change in the patterns of sedimentation and microfauna;

- Reconstructing the main MOW paleoceanographic events for the Pliocene and identifying the role of salt injection from MOW in the dynamics of North Atlantic Deep Water;

- Focusing on calibration of facies and the inferred environmental changes in terms of global rapid climatic events;

- Evaluating the correlation and influence of cold/ warm periods with MOW variation, which can test the concept of cold-period intensification of MOW during the Pliocene and early Pleistocene;

- Determining the sedimentary stacking pattern of Faro Drift in relation to changes in sea level and other forcing mechanisms, determining the potential role of variations in cross-sectional area of the Gibraltar Gateway;

- Evaluating periods of drift construction, nondeposition (hiatuses) and erosion;

- Evaluating the contourite deposition in relation to sea level variation and to the further development of a sequence stratigraphic model; and

- Calibrating and hence understanding the sedimentary cyclicity evident on the deposits, which can characterize their sedimentary expression and regional extent. 


\section{Operations}

The vessel was offset in dynamic positioning mode $2.2 \mathrm{nmi}$ from Site U1386, on a bearing of $128^{\circ}$, to Site U1387 (proposed Site GC-09A). During this move, accomplished in $3 \mathrm{~h}$, maintenance was performed on the $480 \mathrm{~V}$ switchboard, which required shutting down the regulated power from 1800 to $1845 \mathrm{~h}$. The vessel was positioning on Site U1387 at 2030 h, 8 December 2011.

Three holes were drilled at Site U1387 (Table T1). Hole U1387A was cored using the advanced piston corer (APC) to 47.7 meters below seafloor (mbsf) and then with the extended core barrel (XCB) to 352.4 mbsf. Hole U1387B was cored with the APC to 46.9 mbsf and then with the XCB to 338.3 mbsf. Hole U1387C was drilled without coring to $290 \mathrm{mbsf}$ and then cored using the rotary core barrel (RCB) to the target depth of 870 mbsf. Downhole logging was carried out in Hole U1387C using the triple combination (triple combo), Formation MicroScanner (FMS)sonic, and Versatile Sonic Imager (VSI) tool strings (see "Downhole logging at Site U1387"). Overall recovery at Site U1387 was $97.03 \mathrm{~m}(102.6 \%$ recovery) with the APC, $578.42 \mathrm{~m}$ (97\% recovery) with the $\mathrm{XCB}$, and $409.5 \mathrm{~m}$ (70.6\% recovery) with the RCB. The total cored interval at Site U1387 was $1270.7 \mathrm{~m}$, and total recovery was $1084.95 \mathrm{~m}(85.4 \%)$.

\section{Hole U1387A}

Prior to spudding Hole U1387A, a $2 \mathrm{~h}$ underwater camera survey of the seafloor was made during which many linear furrows on the seabed were observed. These furrows were presumed to be the result of fishing bottom trawls. The vessel had to be offset $10 \mathrm{~m}$ from the original position to avoid spudding into what appeared to be man-made debris (a spiral of loose wire or cable). Hole U1387A was spudded with the APC at 0325 h, 9 December. Seafloor depth calculated from the recovery of the first core was established at 570.5 meters below rig floor (mbrf) (559.1 meters below sea level [mbsl]). APC coring advanced to $47.7 \mathrm{mbsf}$, where very sticky, firm clay prevented further progress. The APC cored $47.7 \mathrm{~m}$ and recovered $48.83 \mathrm{~m}$ (102.4\% recovery). Cores 339U1387A-4H through $6 \mathrm{H}$ were oriented. The advanced piston corer temperature tool (APCT-3) was deployed on Core 4H (33.9 mbsf). Nonmagnetic core barrels were used to obtain all piston cores. XCB coring was initiated at 0915 h, 9 December, and deepened Hole U1387A from 47.7 mbsf to a final depth of 352.4 mbsf by $0545 \mathrm{~h}, 10$ December. The XCB system cored $304.7 \mathrm{~m}$ with a $98.1 \%$ recovery. The total cored interval in Hole U1387A was $352.4 \mathrm{~m}$, with a recovery of $98.7 \%$.

\section{Hole U1387B}

The bit was pulled clear of the seafloor at $0715 \mathrm{~h}, 10$ December, and the vessel offset $20 \mathrm{~m}$ east of Hole U1387A. The underwater camera was deployed to ensure no man-made debris was present on the seafloor prior to coring. Hole U1387B was spudded with the APC at $1050 \mathrm{~h}$ and established a water depth of $569.6 \mathrm{mbrf}$ ( $558.2 \mathrm{mbsl})$. Piston coring advanced to 46.9 mbsf (102.8\% recovery) before switching to the XCB. Cores 339-U1387B-3H through 5H were oriented. All cores were obtained with nonmagnetic core barrels.

XCB coring deepened Hole U1387B to a final depth of 338.3 mbsf. The average recovery for the $\mathrm{XCB}$ cored interval of $291.4 \mathrm{~m}$ was $95.9 \%$. APC/XCB coring recovered $96.8 \%$ of the cored interval in Hole U1387B $(338.3 \mathrm{~m})$. Coring was terminated prior to the depth objective of 350 mbsf because the quality of the cores was compromised because of biscuiting disturbance, discovered when the deeper cores in Hole U1387A were examined in the ship's core laboratory.

\section{Hole U1387C}

The drill string was recovered with the bit clearing the rotary table at $1305 \mathrm{~h}, 11$ December. After the nonmagnetic drill collar and seal bore drill collar were laid out along with the APC/XCB polycrystalline diamond bit, a four-stand RCB bottom-hole assembly (BHA) with a new CC-3 Rock Bit International bit was made up and deployed along with the underwater camera. Once the video images provided by the underwater camera confirmed that the seafloor was clear of obstructions, the driller tagged the seabed with the RCB bit at $569.8 \mathrm{mbrf}(558.4 \mathrm{mbsl})$ at $1640 \mathrm{~h}, 11$ December. Following retrieval of the camera, Hole U1387C was spudded with the RCB at $1850 \mathrm{~h}$. The hole was drilled with a wash barrel in place to 290.0 mbsf, where continuous RCB coring was initiated.

Rotary coring proceeded without incident to a final depth of 870 mbsf by 0930 h, 16 December. A total of $580 \mathrm{~m}$ was cored in Hole U1387C with an average recovery of $70.6 \%$. The average rate of penetration for the cored interval was $11.6 \mathrm{~m} / \mathrm{h}$. The drilled portion of the hole was $290 \mathrm{~m}$ and the total penetration (cored plus drilled) was $870 \mathrm{~m}$. While penetrating the cored interval, the drillers pumped eleven $20 \mathrm{bbl}$ and two $30 \mathrm{bbl}$ high-viscosity mud flushes to keep the hole clean of cuttings.

\section{Downhole logging at Site U1387}

After a wiper trip and hole conditioning, the bit was dropped at the bottom of Hole U1387C and the hole 
was displaced with $290 \mathrm{bbl}$ of $10.5 \mathrm{ppg}$ mud. The end of the pipe was positioned at $103.8 \mathrm{mbsf}$. During the wiper trip, the driller had to pick up the top drive and wash and ream a tight portion of the hole (ledge or bridge) from 649.0 to $653.0 \mathrm{mbsf}$. There was $28 \mathrm{~m}$ of soft fill at the bottom of the hole that was flushed clean with a $50 \mathrm{bbl} \mathrm{Hi-Vis} \mathrm{sweep.}$

The triple combo tool string was made up and deployed at $0230 \mathrm{~h}, 17$ December. The tool could not advance past $650 \mathrm{mbsf}$, so the hole was logged from that point. The triple combo tool string was recovered at $0835 \mathrm{~h}$. The VSI tool string was run in the pipe at $1105 \mathrm{~h}$ but could not be lowered deeper than 254 mbsf. The marine mammal protocol was observed while conducting the vertical seismic profile (VSP) experiment. The VSI was recovered at $1420 \mathrm{~h}$. The last log was made with the FMS-sonic tool string, which was deployed at $1610 \mathrm{~h}$ and could not go deeper than 334 mbsf. The FMS-sonic tool string was recovered and disassembled by $2300 \mathrm{~h}$. The end of the pipe was pulled clear of the seafloor at $2355 \mathrm{~h}$, and the drill string was recovered. The drilling equipment was secured and the vessel departed for Site U1388 at 0230 h, 18 December. Total time on site was 9.3 days.

\section{Lithostratigraphy}

Drilling at Site U1387 penetrated a $\sim 870 \mathrm{~m}$ thick section of sediment (Figs. F1, F2). The shipboard lithostratigraphic program at Site U1387 involved detailed visual assessment of grain size, sediment color, sedimentary structures, and bioturbation intensity to describe the facies and facies associations. Petrographic analysis of smear slides taken regularly from each hole (88 from Hole U1387A, 22 from Hole U1387B, and 124 from Hole U1387C) was used to provide detailed sediment description, identify major components, and apply a more descriptive sediment classification. Hand-drawn logs showing the recovered sediment sequence, including the distribution and structure of bedding, are included in the DRAWLOG folder in "Supplementary material."

Ninety samples were selected from Holes U1387A, $\mathrm{U} 1387 \mathrm{~B}$, and U1387C for X-ray diffraction (XRD) analysis of powdered bulk sediment in order to gain a general indication of bulk mineralogy. The clay fraction of every fourth sample was analyzed separately. Based on shipboard analyses, total carbonate contents in these cores range from 12.9 to $36.1 \mathrm{wt} \%$ (average $=26.4 \mathrm{wt} \%$ ), excluding a consolidated dolomite interval at $\sim 460$ mbsf in which carbonate content, reported as $\mathrm{CaCO}_{3}$, is $78.6 \mathrm{wt} \%$ (see "Geochemistry"). These results are consistent with abundances of biogenic and detrital carbonate esti- mated from smear slides, so the lithologic names determined from smear slide analyses have been used without modification throughout the text, the accompanying summary diagrams, and the visual core description sheets.

The sediment at Site U1387 has been divided into four lithologic units (I-IV; Figs. F1, F3). Unit I is a $\sim 450 \mathrm{~m}$ thick Holocene- Pleistocene sequence dominated by nannofossil mud, silty mud with biogenic carbonate, and silty sand with biogenic carbonate. These three lithologies show two distinctive stacking patterns, bi-gradational sequences (Fig. F4) and normally graded sequences (Fig. F5).

Unit II is a $\sim 145 \mathrm{~m}$ thick Pliocene sequence dominated by the same three lithologies as Unit I. However, Unit II is characterized by a clear cyclicity of dark- and light-colored sediments. These cycles are characterized by a downhole change from very dark greenish gray nannofossil mud to a dark greenish gray nannofossil mud to a dark greenish gray silty mud with biogenic carbonate to a basal dark greenish gray silty sand with biogenic carbonate (Fig. F6). The contacts between the lithologies within each cycle generally are gradational. However, the contact between the basal silty sand and the underlying light-dark cycle is generally sharp or erosional and, in some cases, bioturbated (Fig. F6). Biosiliceous microfossils (sponge spicules, radiolarian fragments. and rare diatom fragments) are present in some beds of very dark greenish gray nannofossil mud. Two well-consolidated massive beds (59 and $12 \mathrm{~cm}$ thick) of fine-grained dolomite are intercalated at the top of Unit II (Fig. F7).

Unit III is a $\sim 152 \mathrm{~m}$ thick Pliocene-Miocene sequence (see "Biostratigraphy"). This unit is also composed of the same three lithologies as are found in Units I and II. However, Unit III is distinguished from the overlying units by a higher proportion of the coarser-grained lithologies. In some cases, these lithologies form contorted/convoluted intervals, interpreted as slump deposits (Fig. F8). Two intervals of sandy sediments in Unit III are well lithified (Fig. F9).

Unit IV is a $>115 \mathrm{~m}$ thick Pliocene-Miocene sequence (see "Biostratigraphy"), dominated by nannofossil mud and muddy nannofossil ooze, with minor intercalations of silty mud with biogenic carbonate (Fig. F10).

The character of sediment physical properties, including natural gamma radiation (NGR), magnetic susceptibility, color reflectance parameters, and density, records the distribution of these various lithologies and sediment components (see "Physical properties"). Characteristics of the sedimentary sequence 
cored at Site U1387, together with some of these additional properties, are summarized in Figure F2.

\section{Unit descriptions}

\section{Unit I}

Intervals: Cores 339-U1387A-1H-1, $0 \mathrm{~cm}$, through $38 \mathrm{X}-\mathrm{CC}, 47 \mathrm{~cm}$ (bottom of hole $[\mathrm{BOH}]$ ); 339U1387B-1H-1, $0 \mathrm{~cm}$, through 36X-CC, $18 \mathrm{~cm}$ (BOH); 339-U1387C-1W-1, $0 \mathrm{~cm}$, through 19R$1,106 \mathrm{~cm}$

Depths: Hole U1387A $=0-352.75$ mbsf $(\mathrm{BOH})$, Hole U1387B $=0-337.99$ mbsf $(\mathrm{BOH})$, Hole $\mathrm{U} 1387 \mathrm{C}=0-454.06 \mathrm{mbsf}$

Age: Holocene-Pleistocene

\section{Lithologies and bedding}

The sediment of Unit I is composed of varying mixtures of terrigenous and biogenic components, primarily silicate minerals (quartz, feldspars, and clay minerals), nannofossils, foraminifers, and detrital carbonate (Fig. F11). The three most common lithologies in Unit I are nannofossil mud, silty mud with biogenic carbonate, and silty sand with biogenic carbonate. Nannofossil mud is dominant in Unit I, with its abundance per core varying between 30\% and 100\% (Fig. F3). The abundance of beds of silty mud with biogenic carbonate and silty sand with biogenic carbonate also varies throughout Unit I, with notable increases at 0-100, 170-300, and 340-450 mbsf.

The large-scale variations in lithologic abundances in Unit I at Site U1387 are similar to those in Unit I at Site U1386, $4 \mathrm{~km}$ northwest of this site (Fig. F12). The uppermost $100 \mathrm{~m}$ interval of Unit I at Site U1387 is characterized by a relatively higher proportion of silty sand with biogenic carbonate and is lithologically similar to Subunit IA at Site U1386 (0-110 mbsf). The underlying $~ 70 \mathrm{~m}$ interval at Site U1387 is mostly dominated by nannofossil mud and is lithologically similar to Subunit IB at Site U1386 (110220 mbsf). The deepest interval of Unit I at Site U1387 (170-450 mbsf) is lithologically similar to Subunit IC at Site U1386.

\section{Structures and texture}

Unit I was sampled by the APC in the upper six cores, by the XCB in Holes U1387A and U1387B, and by the RCB in Hole U1387C. As a result, structures are well resolved only in the uppermost interval, although elements of the various lithologies are quite recognizable in the XCB and RCB cores. Coarser sediment (i.e., silty sand with biogenic carbonate and silty mud with biogenic carbonate) forms two distinct bedding styles, bi-gradational grading (Fig. F4) and normal grading (Fig. F5). The bi-gradational se- quences are slightly more common in Unit I than in deeper units, with thicknesses varying from a few decimeters to several meters (Table T2). The most complete examples of the bi-gradational sequence coarsen upward from nannofossil mud through silty mud with biogenic carbonate to silty sand with biogenic carbonate and then fine upward through silty mud with biogenic carbonate into nannofossil mud (e.g., Fig. F4). Some of the sequences are less complete, lacking the silty sand part. The contacts between all lithologies, including between successive beds of nannofossil mud, are primarily gradational and/or bioturbated. The normally graded sequences fine upward, generally from silty sand with biogenic carbonate through silty mud with biogenic carbonate to nannofossil mud (Fig. F5). The normally graded sequences generally have sharp, erosional, or irregular bottom contacts with the underlying nannofossil mud, but their bottom contacts in places become unclear because of bioturbation. Some of these sequences are less complete, lacking the silty sand part. As an exception, a thick bed of silty sand with biogenic carbonate that shows inverse grading and a sharp upper contact is present in Section 339U1387C-16R-3.

Bioturbation and burrows are present throughout Unit I. The most common indicators are diffuse centimeter-scale mottling and millimeter-scale pyritic burrow fills. Black iron sulfide mottling is also common. Discrete burrows and recognizable ichnofossils are rare; those present occur in a few beds with discrete burrows of Chondrites. The bioturbation index ranges from sparse to slight, based on observation of beds with slight color changes.

\section{Composition}

Smear slide observations indicate that all lithologies in Unit I are similar in composition; they are dominated by terrigenous material (siliciclastic minerals such as clay minerals, quartz, feldspars, and mica, plus detrital carbonate) (Fig. F13; Table T3). Abundances of terrigenous components, as estimated from smear slides, are 15\%-75\% (average $=47 \%$ ) siliciclastics such as quartz, feldspars, heavy minerals, clay minerals, and volcanic glass, and 13\%-40\% (average $=29 \%$ ) detrital carbonate. No discrete ash layers and no dropstones were observed.

The biogenic fraction is primarily dominated by nannofossils, with rare to common foraminifers and rare pteropods, sponge spicules, and wood fragments. Abundances of biogenic components, as estimated from smear slides, are 10\%-50\% (average = 23\%) biogenic carbonate (primarily nannofossils, with foraminifers for the silty sand lithology) and $0 \%-5 \%$ (average $=0.4 \%$ ) biogenic silica (primarily di- 
atoms and radiolarians). Siliceous microfossils exceed $2 \%$ only in the upper part of Unit I (0-30 mbsf). Macrofossil fragments and occasional nearly whole specimens of gastropods, bivalves, and echinoderms occur throughout Unit I at Site U1387. Examples of gastropod shells are illustrated in Figure F14, a coral branch in Figure F15, an Arenaria in Figure F16, bivalve shells in Figure F17, and a vermetid-like fossil in Figure F18. Total carbonate contents, as calculated by assuming all inorganic carbon to be $\mathrm{CaCO}_{3}$, range from 18.0 to $35.6 \mathrm{wt} \%$, with an average of $26.4 \mathrm{wt} \%$ in Unit I (see "Geochemistry").

Some authigenic products, such as pyrite and dolomite (mostly recognized by its rhombic shape), are also present through the sequence but do not exceed $5 \%$ abundance. Both pyrite and dolomite generally are present in the silty sand beds. Some dolomite grains are subangular, suggesting a detrital origin. Glauconite grains are also present throughout Unit I.

\section{Color}

A downhole color change is prominent in the uppermost $150 \mathrm{~cm}$ of the core, from yellowish brown (interval 339-U1387B-1H-1, 0-30 cm) through dark reddish gray (interval $1 \mathrm{H}-1,30-150 \mathrm{~cm}$ ) to dark gray. Below 15 mbsf, sediment becomes greenish gray to dark greenish gray, as shown in low $a^{*}$ values. In general, sediments with higher sand and/or carbonate contents have lighter colors.

\section{Bulk mineralogy}

The mineral composition of 47 bulk sediment samples from Unit I was analyzed by XRD. Diffraction peaks from silicate minerals, such as quartz, plagioclase, and illite, and carbonate minerals, such as calcite and dolomite, contribute most of the total diffraction peak intensity measured (Fig. F19; Table T4). Intensities of the quartz diffraction peak in nannofossil muds and silty muds with biogenic carbonate generally vary between 18,000 and 40,000 counts in Unit I, whereas two samples of silty sand with biogenic carbonate (Samples 339-U1387A-29X-6, 137$138 \mathrm{~cm}$, and 339-U1387C-14R-4, 70-71 cm) show significantly higher intensities of 50,000-65,000 counts. Peak intensity of calcite varies between 9,000 and 19,000 counts in Unit I, showing no clear trend with lithology. However, the measured inorganic carbon content and calcite + dolomite peak intensities are closely correlated. The intensity of the illite diffraction peak ranges between 3,000 and 16,000 counts, showing higher intensities in some nannofossil muds and silty muds with biogenic carbonate around 0-70 and 200-450 mbsf. Other clay minerals, such as chlorite and kaolinite, show similar trends. Plagioclase tends to be slightly more abundant in coarser sediments (i.e., silty mud with biogenic carbonate and silty sand with biogenic carbonate). Sediment between 240 and 410 mbsf contains slightly more hornblende than the other intervals of Unit I.

XRD patterns of ethylene glycolated samples generally show a well-defined smectite peak for most samples in Unit I (shown in red in Fig. F20). Exceptions are a nannofossil mud (Sample 339-U1387A-37X6W, 98-99 cm; $341.68 \mathrm{mbsf}$ ), a silty sand (Sample 29X-6W, 137-138 cm; $264.62 \mathrm{mbsf}$ ), and a second nannofossil mud (Sample 21X-6W, 92-93 cm; 188.52 mbsf).

\section{Unit II}

Interval: 339-U1387C-19R-1, $106 \mathrm{~cm}$, through 34R-2, $90 \mathrm{~cm}$

Depth: Hole U1387C $=454.06-599.10 \mathrm{mbsf}$

Age: Pliocene-earliest Pleistocene

\section{Lithologies and bedding}

Unit II is composed of the same sediment types as those of Unit I (i.e., nannofossil mud, silty mud with biogenic carbonate, and silty sand with biogenic carbonate). Twelve beds in Unit II have contourite characteristics similar to those of beds in Unit I, such as gradational and bioturbated basal contacts and basal zones with inverse grading (examples are located in Sections 339-U1387C-23R-4, 25R-3, and 27R-4). However, Unit II is clearly distinguished from Unit I based on a distinctive cyclicity of dark and light colors (Fig. F6). Approximately 50 cycles are recognized in Unit II, with thicknesses varying from 1 to $5 \mathrm{~m}$. Typically, one cycle is composed of the following lithologies from top to bottom: very dark greenish gray nannofossil mud, overlying greenish gray to dark greenish gray nannofossil mud, overlying greenish gray to dark greenish gray silty mud with biogenic carbonate, overlying greenish gray to dark greenish gray silty sand with biogenic carbonate (Fig. F6). In general, the dark-light nannofossil mud facies forms $>80 \%$ of each cycle. Lithologic contacts within a cycle are gradational or bioturbated, whereas the basal contact of the silty sand with biogenic carbonate generally is sharp or erosional. In some cases, however, the basal contact is bioturbated (Fig. F6). The very dark greenish gray nannofossil muds also contain trace amounts of siliceous microfossils (e.g., fragmented and rare whole radiolarians, diatoms, and sponge spicules).

The upper boundary of Unit II is defined at 454.06 mbsf (interval 339-U1387C-19R-1, $106 \mathrm{~cm}$ ), which is the top of the shallowest bed of very dark greenish gray nannofossil mud $>1 \mathrm{~m}$ thick and represents the start of the distinctive sediment cycles. This depth is also near the Pliocene/Pleistocene boundary. 
Two dolostone beds are present near the upper boundary of Unit II, at 457.3-458.0 (Sections 339U1387C-19R-3 and 19R-4) and 462.7-462.8 mbsf (Section 20R-1)(Fig. F7). Discussion during initial core description considered whether the lower dolostone material might have fallen into the hole between Cores 339-U1387C-19R and 20R, especially because the drill bit was raised $\sim 10 \mathrm{~m}$ between cores. However, the logging results (see "Downhole measurements") clearly show two high-resistivity beds at this depth, an upper bed $\sim 70 \mathrm{~cm}$ thick separated by $\sim 120 \mathrm{~cm}$ from a $\sim 40 \mathrm{~cm}$ thick lower bed. These results indicate that the uppermost part of Core 339U1387C-20R (i.e., the lower dolostone bed) represents material recovered in place.

These dolostone layers are composed of almost pure dolomite (3-10 $\mu \mathrm{m}$ dolomite grains) (Fig. F7) but contain a few quartz grains, opaques, and ghosts of siliceous microfossils such as radiolarians and diatoms, some of which are replaced by opaque minerals and silica. Based on petrographic observations, we speculate that the dolostones were originally fine-grained sediments (mud or silty mud) that contained siliceous microfossils. Nannofossils are rare in the very dark greenish gray muds immediately above the upper dolostone bed (interval 339-U1387C-19R$3,66-136 \mathrm{~cm}$ ) and are absent below that bed (interval 19R-4, 48-100 cm) (Fig. F7).

The lowermost boundary of Unit II is defined at 599.10 mbsf (interval 339-U1387C-34R-2, $90 \mathrm{~cm}$ ), at the top of the shallowest of the thick, contorted beds that characterize Unit III (see "Unit III").

\section{Structures and texture}

The distinctive cycles in Unit II display normal grading, fining up from silty sand with biogenic carbonate through silty mud with biogenic carbonate to nannofossil mud. The basal contacts of these silty sand beds generally are sharp or erosional, although some are bioturbated (Fig. F6). Burrows filled with silty sand with biogenic carbonate are common, extending downward from the silty sand with biogenic carbonate at the base of one cycle into the underlying very dark greenish gray nannofossil muds at the top of the previous cycle. In some cases, these sandfilled burrows extend several decimeters below the base of the overlying silty sand layer. Bioturbation is also visible around the contacts between very dark greenish gray nannofossil mud and dark greenish gray nannofossil mud (Fig. F6). Some nannofossil mud beds near the base of Unit II show parallel laminations (Sections 339-U1387C-33R-6 to 34R-2), apparently defined by color variations.

Bioturbation is present throughout Unit II but is more visible below lithologic boundaries (e.g., below greenish gray silty sand with biogenic carbonate; Fig. F6). Characteristics of the bioturbation are similar to those of the bioturbation in Unit I. The bioturbation index in Unit II ranges from sparse to slight.

\section{Composition}

Similar to Unit I, all lithologies in Unit II are dominated by terrigenous materials, including siliciclastic components (clay minerals, quartz, feldspars, mica, and volcanic glass), which form $20 \%$ to $68 \%$ (average $=45 \%$ ) of the grains observed in smear slides, and detrital carbonate, with abundances of $15 \%$ 35\% (average $=28 \%$ ) (Fig. F13; Table T3).

The biogenic fraction is dominated by nannofossils, with rare to common foraminifers and rare pteropods and sponge spicules in the silty muds and silty sands. Abundances of biogenic components are $15 \%-50 \%$ (average $=26 \%$ ) biogenic carbonate and $0 \%-5 \%$ (average $=0.7 \%$ ) biogenic silica (primarily diatoms and radiolarians). Two samples immediately above and below the dolostone (Samples 339U1387C-19R-3, $134 \mathrm{~cm}$, and 19R-4, $50 \mathrm{~cm}$ ) have rare biogenic carbonate $(1 \%-2 \%)$ but slightly more biogenic silica (5\%-7\%) (Table T3). The very dark greenish gray nannofossil muds generally contain more siliciclastic minerals, opaques (pyrite), and rare siliceous microfossils, whereas the dark greenish gray nannofossil muds contain more nannofossils but no siliceous microfossils. Excluding the dolostones, total carbonate contents in Unit II, as calculated by assuming all inorganic carbon to be $\mathrm{CaCO}_{3}$, range from 12.9 to $34.1 \mathrm{wt} \%$ (average $=25.0 \mathrm{wt} \%$ ). The carbonate content of the dolostone is $78.6 \mathrm{wt} \%$ when reported as $\mathrm{CaCO}_{3}$ (see "Geochemistry").

Other minerals, such as pyrite, dolomite, and glauconite, are also present throughout Unit II. Abundances of these minerals, as estimated from smear slides, are $<5 \%$ for pyrite (usually classified as opaque grains, and associated with burrows), $<5 \%$ for dolomite (found as rhombic crystals), and $<5 \%$ for glauconite. Glauconite and dolomite are abundant locally in the silty sand beds. No discrete ash layers or dropstones were observed.

Sediment compositions generally are similar for Unit I and Unit II, with the exception of the dolostones at the upper boundary of Unit II. Thin sections of these dolostones indicate that the sediment is composed almost entirely of dolomite grains, which presumably were formed during diagenesis, with trace silicate minerals (3\%-5\%) and a few ghosts of siliceous microfossils, such as radiolarians and diatoms (Fig. F7B).

Macrofossil fragments distributed through most of Unit II include fragments of bivalves, echinoderms, 
corals, and Arenaria. The few specimens found include recognizable coral fragments (Sample 339U1387C-28R-4, 31 cm; Fig. F21).

\section{Color}

The principal colors of the lithologies in Unit II range from greenish gray to very dark greenish gray. In general, sediments with higher quartz and/or carbonate contents are lighter colors, whereas sediments containing more clay minerals and opaque grains are darker colors.

\section{Bulk mineralogy}

The mineral composition of 17 bulk sediment samples in Unit II was analyzed by XRD. Diffraction peaks from quartz, calcite, illite, and dolomite account for most of the total diffraction peak intensities measured (Fig. F19; Table T4). Quartz peak intensity ranges between 18,000 and 30,000 counts, which is slightly lower than its intensity in samples from Unit I. Calcite peak intensity is approximately 17,000-20,000 counts, slightly higher than in Unit I. Clay minerals such as illite, kaolinite, and chlorite have lower peak intensities in Unit II than in Unit I, whereas smectite has a slightly higher peak intensity in Unit II. XRD patterns of ethylene glycolated samples show a well-defined smectite peak for each sample from Unit II (Fig. F20). A dark greenish gray nannofossil mud near the lower boundary of Unit II shows the highest peak intensities for smectite, chlorite, kaolinite, and illite (Sample 339-U1387C-32R-6, 90-91 cm). Hornblende and plagioclase are less abundant in Unit II than in Unit I. The dolostone sample (339-U1387C-19R-4, 39-41 cm) shows clear peaks of dolomite and quartz, but no other minerals were identified.

\section{Unit III}

Interval: 339-U1387C-34R-2, $90 \mathrm{~cm}$, through 50R$1,52 \mathrm{~cm}$.

Depth: Hole U1387C $=599.10-750.92$ mbsf

Age: late Miocene-Pliocene

\section{Lithologies and bedding}

Unit III is composed mainly of the same sediment types as are present in Unit II: greenish gray to very dark greenish gray nannofossil mud, dark greenish gray silty mud with biogenic carbonate, and dark greenish gray silty sand with biogenic carbonate. In contrast to Unit II, in which a clear cyclicity of these lithologies is expressed as color changes, these lithologies are not stacked as regularly in Unit III. For example, nannofossil mud is missing in some intervals (e.g., from Section 339-U1387C-40R-6 to 42R-6). Also, in contrast to the undeformed strata in Unit II, a $\sim 4.7 \mathrm{~m}$ thick bed of nannofossil mud at 599.10603.82 mbsf (interval 339-U1387C-34R-2, $90 \mathrm{~cm}$, to $34 \mathrm{R}-\mathrm{CC}, 23 \mathrm{~cm}$ ) is highly contorted, including recumbent fold limbs as thick as $50 \mathrm{~cm}$ (Fig. F8). This bed is interpreted as a slump deposit, and the top of this deformed bed defines the top of Unit III. Similar deformed beds, which are recognizable by recumbent folds and/or inclined laminations, are observed throughout Unit III.

Beds of very dark greenish gray silty sand with biogenic carbonate, $\sim 30-120 \mathrm{~cm}$ thick, also characterize Unit III (Fig. F22). These beds contain abundant shell fragments, as well as a few granules that generally are rounded and mainly composed of quartzite, with trace abundances of metamorphic rock fragments. One of the very dark greenish gray silty sand beds with biogenic carbonate (interval 339-U1387C39R-3, 76-110 cm) shows a clear coarsening-upward trend (inverse grading) and a sharp inclined contact with the overlying bed.

Sediment in intervals 339-U1387C-44R-1, $0 \mathrm{~cm}$, through 47R-1, $47 \mathrm{~cm}$ (692.90-722.09 mbsf) and 49R-CC, $0 \mathrm{~cm}$, through 50R-1, $52 \mathrm{~cm}$ (748.10-750.92 mbsf) is dominated by well-cemented gray medium sandstone with biogenic carbonate (Fig. F9), which contains rare very coarse sand- to granule-size grains. As recovered, these gray medium sandstones are interbedded locally with dark greenish gray silty/ muddy fine sandstone with biogenic carbonate. Because recovery is poor in this interval, however, with only $21.0 \mathrm{~m}$ of material recovered in $69.3 \mathrm{~m}$ of coring from Cores 339-U1387C-43R through 50R, the true stratigraphic relationships between the well-cemented gray medium sandstone and the dark greenish gray silty/muddy fine sandstone are unknown. The gray medium sandstone with biogenic carbonate is moderately sorted and shows no evidence for bioturbation. The dark greenish gray silty/muddy fine sandstone with biogenic carbonate is moderately to poorly sorted and also shows no evidence of bioturbation.

The petrographic observation of a thin section from the dark greenish gray silty sandstone (interval 339U1387C-44R-1, 9-14 cm) indicates that fine sand grains are supported by a matrix of silt-sized carbonate, which is partly replaced by calcite cement (Fig. F9). The silty matrix accounts for $\sim 30 \%$ of each field of view, with $\sim 40 \%$ siliciclastic grains (mostly quartz with trace feldspars, heavy minerals, and mica) and $\sim 30 \%$ biogenic carbonate grains (foraminifers and shell fragments). Most of the quartz grains are angular, although some grains of rounded quartz, polycrystalline quartz, or quartzite are also present. This variety of grain shapes and compositions indicates multiple sources for these quartzose grains. Well- 
rounded grains of green glauconite are present, indicating reworking of sediments from the shelf margin. Some benthic foraminifers are also present.

Petrographic analysis of a thin section of gray medium sandstone (interval 339-U1387C-45R-1, 74-77 $\mathrm{cm}$ ) reveals a grain-supported medium sand with calcite cement filling the pore spaces (Fig. F9). The calcite cement accounts for $\sim 20 \%$ of each field of view, with $\sim 75 \%$ siliciclastic grains (mostly plagioclase, quartz, and K-feldspar, with trace mica and rock fragments) and $\sim 5 \%$ foraminifers. This sample has a high percentage of feldspars, almost reaching the 25\% level necessary for its description as an arkose.

A thin $(\sim 4 \mathrm{~cm})$ bed of black carbonaceous sediment present in interval 339-U1387C-42R-5, 63-67 cm (680.13-680.17 mbsf), contains interlaminated silty sand and terrestrial organic debris (Figs. F23, F24). This bed is overlain by a normally graded medium bed of silty sand with biogenic carbonate.

The lower boundary of Unit III is at 750.92 mbsf (interval 339-U1387C-50R-1, $52 \mathrm{~cm}$ ), which is the deepest occurrence of a bed of sandy sediment (silty sand, sand, and sandstone) thicker than $2 \mathrm{~cm}$. Five very thin interbeds of silty sand with biogenic carbonate are present between 750.92 mbsf and Section 339U1387C-54R-3, but all five are $2 \mathrm{~cm}$ thick or less. Excluding these very thin sandy beds, the underlying sediment is a continuous succession of the nannofossil mud and muddy nannofossil ooze that characterizes Unit IV.

In summary, Unit III is distinguished from Units I and II by:

- More complex composition, reflecting more geologically diverse sources;

- The presence of contorted mud beds, most likely associated with slumping;

- The increased abundance of coarser lithologies; and

- The presence of sandstone beds (Fig. F3).

\section{Structures and texture}

Similar to the lowermost part of Unit II, parallel laminations are visible throughout Unit III, particularly in fine-grained sediments such as nannofossil mud and silty mud with biogenic carbonate. Some coarser sediment (i.e., silty mud with biogenic carbonate) also shows subtle parallel laminations. In some cases, these laminations form recumbent folds and/or inclined laminations, indicating slump deposits.

Most of the beds of dark greenish gray silty sand with biogenic carbonate display normal grading, fining upward from a sharp, irregular, or erosional basal contact. However, in some cases the nature of the basal contact is unclear because of bioturbation. In contrast, the very dark greenish gray silty sands with biogenic carbonate in Cores 339-U1387C-39R and 40R contain abundant shell fragments but show no clear evidence of normal grading; in fact, three of these silty sand layers are inversely graded (Sections 339-U1387C-39R-3, 40R-2, and 41R-2).

Unit III contains a higher proportion of coarser sediment, such as silty sand with biogenic carbonate, than Units I and II, and has an average grain size of silt to fine sand and a maximum grain size of medium sand to granule. This contrasts with Units I and II, which contain a higher proportion of finegrained sediment and have an average grain size of clay to silt.

Bioturbation is the most obvious secondary sedimentary structure in Unit III and is present throughout the observed section. Characteristics of the bioturbation are similar to those of Units I and II, with a bioturbation index ranging from sparse to slight. In some parts of Unit III, burrows are filled with fine pyrite grains or have been pyritized. Some vertical veins of pyrite, 5-11 cm long, and a microfault in Section 339-U1387C-40R-4 are additional secondary structures.

\section{Composition}

As is true for Units I and II, all lithologies in Unit III are dominated by terrigenous material. The abundance of siliciclastic components, such as clay minerals, quartz, feldspars, and mica, ranges from $30 \%$ to $62 \%$ (average $=46 \%$ ), and the abundance of detrital carbonate ranges from $15 \%$ to $35 \%$ (average = 27\%) (Fig. F13; Table T3). Abundances of biogenic components range from $20 \%$ to $50 \%$ (average = $28 \%$ ), and the biogenic fraction is composed entirely of biogenic carbonate (primarily nannofossils, with rare to common foraminifers in the silty sand and silty mud lithologies). Biosiliceous microfossils are not observed in Unit III. Total carbonate contents range from 18.2 to $38.2 \mathrm{wt} \%$ (average $=29.7 \mathrm{wt} \%$ ) in Unit III, excluding two sandstone samples (339U1387C-44R-1, 37-38 cm, and 45R-1, 76-77 cm) that contain 71.7 and $37.2 \mathrm{wt} \%$ carbonate, respectively, as $\mathrm{CaCO}_{3}$ (see "Geochemistry"). Macrofossil debris is distributed through most of Unit III as recognizable fragments, including bivalves, echinoderms, and corals. Shell fragments are particularly abundant in some beds of the very dark greenish gray silty sand with biogenic carbonate.

Authigenic components are dominated by pyrite $(<5 \%)$, usually classified as opaque grains and associated with burrows, dolomite $(<5 \%)$, found as rhombic crystals, and glauconite $(<5 \%)$. Glauconite and dolomite are common in some of the silty sand beds. 
These results are similar to the corresponding component abundances in Units I and II, except for the absence of biosiliceous microfossils.

\section{Color}

The principal colors of the lithologies in Unit III range from greenish gray to very dark greenish gray. The sandstones in intervals 339-U1387C-44R-1, 0 $\mathrm{cm}$, to 47R-1, $47 \mathrm{~cm}$ (692.90-722.09 mbsf), and 49RCC, $0 \mathrm{~cm}$, to $50 \mathrm{R}-1,52 \mathrm{~cm}(748.10-750.92 \mathrm{mbsf})$, are gray to dark greenish gray. The thin $(\sim 4 \mathrm{~cm})$ bed of carbonaceous sediment in interval 339-U1387C-42R5 , 63-67 cm (680.13-680.17 mbsf) is black (Fig. F23). In general, sediments with higher sand and/or carbonate contents are lighter colors.

\section{Bulk mineralogy}

Fifteen bulk sediment samples from Unit III were analyzed by XRD. Diffraction peak intensities for quartz, calcite, and illite are the major contributors to the total peak intensities identified for each sample (Fig. F19; Table T4). Quartz peak intensity ranges between 17,000 and 46,000 counts, with an exceptionally high intensity of $\sim 84,000$ counts in a sample of the medium sandstone (Sample 339-U1387C-45R1, 76-77 cm). A muddy fine sandstone sample (339U1387C-44R-1, 37-38 cm) shows a much lower peak intensity for quartz, indicating a range of mineral compositions in the sandstones. Calcite peak intensity ranges between 16,000 and 22,000 counts, excluding the two sandstone samples. These results are similar to those of Unit II.

In the two sandstone samples (339-U1387C-44R-1, $37-38 \mathrm{~cm}$, and 45R-1, 76-77 cm), calcite XRD peak intensities are $\sim 39,000$ and $\sim 91,000$ counts, respectively, which are much higher than the calcite intensities for other samples. The relative sizes of these calcite peak intensities are apparently inconsistent with the geochemical analysis of carbonate contents in these two samples, which gave values of 71.7 and $37.2 \mathrm{wt} \%$, respectively (see "Geochemistry"). We attribute the exceptionally high intensity of the calcite peak in the gray medium sandstone (Sample 339U1387C-45R-1, 76-77 cm) to the very highly crystalline nature of its calcite cement, compared with the cement of the silty fine sandstone sample (44R-1, $37-38 \mathrm{~cm})$. Support for this interpretation comes from petrographic observations of thin sections from the two sandstones, which indicate that the calcite cement in the gray medium sandstone is very highly crystalline compared with the cements of the dark greenish gray silty fine sandstone (Fig. F9). The gray medium sandstone also shows the highest peak intensity for plagioclase and K-feldspar, which is consistent with the observation that some of the rocks analyzed by thin section had high percentages of feldspar, almost reaching the $25 \%$ level necessary to describe the sample as an arkose.

A nannofossil mud sample at 619.7 mbsf (Sample 339-U1387C-36R-3, 78-79 cm) shows the highest peak intensities in Unit III for clay minerals such as illite, kaolinite, and chlorite. The remaining intervals in Unit III are characterized by low abundances of clay minerals. Smectite is an exception to this statement, in that it appears to have a higher average intensity count in Unit III than in the other lithologic units. However, the XRD patterns of three ethylene glycolated samples from Unit III (Samples 339U1387C-36R-3W, 78-79 cm; 40R-5W, 87-89 cm; and $44 \mathrm{R}-1 \mathrm{~W}, 37-38 \mathrm{~cm}$ ) do not show a clear smectite peak (Fig. F20), suggesting difficulties in using the automated mineral identification software to identify smectite on diffractograms of unglycolated samples. Further analysis after glycolation is necessary to confirm the presence of smectite in each sample.

\section{Unit IV}

Interval: 339-U1387C-50R-1, $52 \mathrm{~cm}$, through 61RCC, $16 \mathrm{~cm}$

Depth: Hole U1387C $=$ 750.92-865.85 mbsf (bottom of hole)

Age: late Miocene-earliest Pliocene

\section{Lithologies and bedding}

The dominant lithologies in Unit IV are nannofossil mud and muddy/clayey nannofossil ooze (Fig. F3). In the upper $\sim 50 \mathrm{~m}$ of this unit (interval 339U1387C-50R-1, $52 \mathrm{~cm}$, to $55 \mathrm{R}-4,26 \mathrm{~cm})$, very thin (2 $\mathrm{cm})$ beds of dark greenish gray silty sand with biogenic carbonate and thick beds of dark greenish gray silty mud with biogenic carbonate $(<1.2 \mathrm{~m}$ thick) are interbedded with thick $(>1 \mathrm{~m})$ beds of dark to very dark greenish gray nannofossil mud. Some darklight cycles, similar to those in Unit II, are present in the upper $\sim 20 \mathrm{~m}$ of Unit IV (Sections 339-U1387C50R-1 to 52R-3). The deepest occurrence of a thick $(\sim 80 \mathrm{~cm})$ bed of silty mud is in Sections 339U1387C-55R-3 and 55R-4. The middle part of Unit IV (interval 339-U1387C-55R-4, $26 \mathrm{~cm}$, through 58RCC, $28 \mathrm{~cm}$; $803.16-834.38 \mathrm{mbsf}$ ) is dominated by dark greenish gray nannofossil mud, and the lower part of Unit IV (interval 339-U1387C-59R-1, $0 \mathrm{~cm}$, through 61R-CC, $16 \mathrm{~cm}$; 836.80-865.85 mbsf) is dominated by dark greenish gray clayey/muddy nannofossil ooze (Fig. F10).

\section{Structures and texture}

Sediment in Unit IV locally shows subtle parallel laminae, which are the only primary sedimentary structure visible. Bioturbation is common through- 
out this unit and is particularly apparent near color contacts between beds. Bioturbation intensity generally is slight. Some ichnofauna such as Chondrites appear throughout Unit IV. In addition, diffuse centimeter-scale mottling and millimeter-scale pyritic burrow fills are also present throughout the unit. In some cores disturbed during drilling, sedimentary structures are poorly preserved (e.g., Core 339U1387C-57R).

The sediment grain size in Unit IV is uniformly fine, with an average grain size of clay. The maximum grain size is medium sand because of the presence of foraminifers.

\section{Composition}

The major lithologies in Unit IV are nannofossil mud and clayey/silty nannofossil ooze. The relative proportion of terrigenous components decreases compared to their abundances in Unit III, whereas the relative proportion of biogenic carbonate (especially present as nannofossils) increases. Siliciclastic abundances in Unit IV are 20\%-70\% (average $=42 \%$ for clay minerals, quartz, feldspars, and mica) and detrital carbonate abundances are 15\%-30\% (average $=19 \%$ ) (Fig. F13). The increase in biogenic carbonate is most prominent in the lower part of Unit IV. Total carbonate contents, calculated as $\mathrm{CaCO}_{3}$, range from 27.6 to $35.9 \mathrm{wt} \%$ (average $=30.3 \mathrm{wt} \%$ ) in Unit IV (see "Geochemistry"), which is slightly higher than the total carbonate contents of other lithologic units. Fragments of shallow-water shells are rare in Unit IV.

\section{Color}

The principal color of the lithologies in Unit IV is very dark greenish gray to greenish gray, with subtle changes in color caused by bioturbation. Several color bands have sharp contacts (e.g., interval 339U1387C-59R-3, $24 \mathrm{~cm}$ ).

\section{Bulk mineralogy}

Eleven bulk samples from Unit IV were analyzed by $X R D$. The peak intensities for quartz decrease downcore, whereas the peak intensities for calcite are variable but increase slightly downcore (Fig. F19; Table T4). XRD patterns for three ethylene glycolated samples from Unit IV show well-defined smectite peaks and indicate variable smectite/illite ratios among these samples (Fig. F20).

\section{General observations \\ Contourites and turbidites in Unit I}

\section{Discussion}

Given the setting of Site U1387, several lines of evidence support the interpretation of Unit I as a sequence mainly composed of contourite deposits, providing evidence for current transport and changing flow speeds. Among these lines of evidence are

- The major lithologies present in Unit I,

- The relative abundances of these lithologies, and

- The organization of these lithologies into bi-gradational sequences with a predominance of gradational contacts and extensive burrow mottling.

Three intervals in Unit I (0-100, 170-300, and 340$450 \mathrm{mbsf}$ ) are relatively typical examples of a mixed sandy/muddy contourite succession as defined by Gonthier et al. (1984) (Fig. F3), whereas the other parts of Unit I (122-170 and 300-340 mbsf) are relatively typical examples of a muddy/silty contourite bed succession. Unit I also contains beds that show normal grading and sharp or erosional basal contacts. Some of these may be true turbidites, whereas others we interpret as base-cut-out contourites. We identified at least 65 bi-gradational sequences with sandy contourites and 31 normally graded beds in Unit I (Figs. F2, F23). As described above, Unit I at Site U1387 can be correlated to Unit I at nearby Site U1386 (located $\sim 4 \mathrm{~km}$ northwest of Site U1387). Compared with the sedimentary succession in Unit I at Site U1386, which is dominated by sandy contourites and muddy contourites and has only a few turbidites, Unit I at Site U1387 contains more beds that have been interpreted as turbidite deposits (Fig. F24). This difference in depositional processes between Sites U1386 and U1387 could be related to the fact that Site U1387 is located closer to a bathymetric channel, previously described by Llave et al. (2001, 2007a) and Hernández-Molina et al. (2006).

\section{Cycles in Unit II}

Unit II is dominated by cyclic variations in color and lithology, 1-5 $\mathrm{m}$ thick. The base of each cycle generally is composed of light-colored silty sand with biogenic carbonate that grades upward into

- An overlying light-colored silty mud,

- An overlying light-colored nannofossil mud, and

- An upper dark-colored nannofossil mud.

The basal light-colored silty sand shows normal grading with sharp/erosional basal contacts (Fig. F6). The characteristics of the basal silty sand (i.e., normal grading and a sharp bottom contact) suggest 
that the basal silty sand bed represents a turbidite; however, no diagnostic stratification styles or sedimentary structures can be recognized within these silty sands. An alternative interpretation is that the basal silty sand layer was formed by bottom current flow.

The upper dark-colored nannofossil mud in each cycle is characterized by an increase in bioturbation and burrows. This muddy portion of the cycle is interpreted as a muddy contourite. The burrows are generally filled with silty sand, whose grain size and composition are almost identical to those of the overlying basal silty sand. This indicates that the burrows formed during or soon after deposition of the silty sand layer at the base of the overlying unit. If the basal silty sand was deposited by a turbidity current, then we suggest that the upper part of the light-colored nannofossil mud was deposited as finegrained sediment originally supplied by the turbidity current was reworked and deposited by bottom water currents. In this scenario, the gradual color change from the lighter to the darker nannofossil mud within a cycle records a gradual change in depositional processes from a downslope turbidity current to alongslope bottom water currents. In other words, these sediments can be regarded as a combination of turbidite and contourite. Interpretation of the normally graded silty sand beds in Unit I (Fig. F5), which are not associated with similar changes in their overlying muds, requires further work. In contrast, the cycles of Unit II likely formed by the interplay of turbidity currents and bottom currents (Figs. F2, F24).

Based on the shipboard age-depth model (see "Biostratigraphy"), the ages for Sections 339-U1387C19R-CC (458.6 mbsf) and 29R-CC (558.6 mbsf) are 3.19 and $3.8 \mathrm{Ma}$, respectively. Within that interval of $\sim 0.6$ m.y., $~ 30$ cycles were deposited in Unit II, for an average duration of $\sim 20 \mathrm{k} . \mathrm{y}$. per cycle.

\section{Coarse shelly sand layers in Unit III}

At least three thick to very thick beds of dark to very dark greenish gray silty sand, which contain abundant shell fragments and sparse well-rounded quartzite granules, are present in Unit III (e.g., Section 339U1387C-39R-2). These beds are very poorly sorted, massive, and exhibit sharp contacts with the overlying and underlying beds. Based on these characteristics, these beds are interpreted as deposits associated with higher concentration sediment mass gravity flows and therefore are considered to be debrites. These debrites occur in association with some softsediment deformation and contorted bedding, interpreted to indicate slump deposits. The presence of debrites and slump deposits may suggest that downslope processes were much more influential during the deposition of Unit III, and these deposits could be correlated laterally with similar debrites and bioclastic turbidites at Site U1386 (see "Lithostratigraphy" in the "Site U1386" chapter [Expedition 339 Scientists, 2013d]).

\section{Formation of dolostone}

Based on petrographic observations, we speculate that the dolostone was originally fine-grained sediment (mud or silty mud) that contained siliceous microfossils. The very dark greenish gray mud immediately above the dolostone contains very few nannofossils (interval 339-U1387C-19R-3, 66-136 $\mathrm{cm})$. The very dark greenish gray mud below the dolostone (interval 19R-4, 48-100 cm) contains no nannofossils but does contain biosiliceous microfossils (radiolarians, diatoms, and sponge spicules). These observations suggest that sediments in the depth intervals now occupied by the dolostone (457.3-458.0 and 462.7-462.8 mbsf) were originally enriched in biosiliceous microfossils, which were most likely replaced by the fine-grained dolomite during diagenesis. Shipboard micropaleontological investigation identified a $\sim 1.3$ m.y. hiatus (i.e., from 3.19 to $1.9 \mathrm{Ma}$ ) between Sections 339-U1387C-19R-1 and 19R-CC (see "Biostratigraphy"). We speculate that formation of the dolostone is closely linked to the hiatus; extensive precipitation of dolomite might have occurred at a shallow depth below the sediment/water interface (probably $<10 \mathrm{~m}$ below the paleoseafloor), where the sulfate reduction-methanogenesis zone was located for at least $1 \mathrm{~m} . \mathrm{y}$.

\section{Depositional history}

The overall depositional history of Site U1387 can be summarized as follows:

1. Deposition of nannofossil ooze and nannofossil mud (hemipelagic processes?) during the late Miocene and the late Miocene-early Pliocene transition (Unit IV);

2. More active downslope transport processes until the early Pliocene (Unit III);

3. Deposition of interbedded turbidites and contourites, and possible current reworking of turbidites, to form dark-light color cycles from the early Pliocene to the late Pliocene (Unit II), and finally;

4. Deposition of sandy and muddy contourites and some turbidites during the Pleistocene to Holocene. During this time, long-term variations in the relative importance of sand input and/or current strength produced mixed sandy/ muddy contourite successions $40-130 \mathrm{~m}$ thick (Unit I). 
During the late Miocene, fine-grained sediment such as nannofossil ooze and nannofossil mud were deposited in a low-energy, likely hemipelagic, depositional environment. A lithologic change from nannofossil ooze to nannofossil mud in the lower to middle part of Unit IV (Fig. F1) indicates that the input of terrigenous siliciclastic components gradually increased through time. An increasing influence of turbidity currents during the late Miocene/early Pliocene (upper part of Unit IV) is indicated by the first occurrence of a thick bed $(\sim 80 \mathrm{~cm})$ of silty mud at 803 mbsf (Sections 339-U1387C-55R-3 and 55R-4) and an increase in the number of thin silty sand beds (Fig. F24).

The depositional environment changed during the late Miocene/early Pliocene from the hemipelagic mud-dominated environment (Unit IV) to one with an increasing input of sandy sediment (Unit III)., However, the details of the transition from the muddominated Unit IV to the sand-dominated Unit III are unclear because of poor recovery. The increase in sandy sediments in Unit III is associated with an increase in downslope transport processes, indicated by the presence of slump deposits and debris flow deposits within a sequence dominated by sandy turbidites (Figs. F2, F22, F24). Some silty sand beds in Unit III are interpreted as sandy contourites, indicating that bottom currents were active during the early Pliocene.

The processes that deposited Unit II, which is characterized by interbedded turbidites and contourites and the distinctive dark-light cycles, dominated deposition until the late Pliocene, probably 2.19 Ma. In support of this interpretation, Roque et al. (2012) also concluded that turbidite processes were important in this area during the early Pliocene. The hiatus between $\sim 3.19$ and $1.9 \mathrm{Ma}$ is marked by two beds of dolostone, which are interpreted to have formed by shallow diagenetic processes during this extended time of seafloor stability.

The depositional environment after the hiatus (Unit I) was dominated by alongslope processes and bottom currents, depositing muddy/silty contourites and sandy contourites with minor influence of downslope turbidity currents (Fig. F24). We recognize at least three intervals within Unit I that suggest stronger alongslope flow and/or a more proximal source of sand, as recorded by more frequent occurrences of sandy contourite beds (0-100, 170-300, and 340-450 mbsf) (Fig. F24). In these intervals the number of turbidite beds is also higher, indicating that downslope processes were also slightly more active during these times. The intervening intervals in Unit I are dominated by muddy contourites, indicating weakening of alongslope transport and/or a re- duced sand supply at Site U1387. These trends are similar to those seen at Site U1386, $\sim 4 \mathrm{~km}$ northwest of this site. As discussed in the Site U1386 chapter, three scenarios can explain the variation between mud-rich and sand-rich contourite intervals:

1. Overall change in strength of the bottom current system;

2. Migration of the core of the bottom current; and

3. Deactivation of turbiditic channels, reducing the supply of silt and sand to the areas of Sites U1386 and U1387. This scenario was described previously by Llave et al. (2001, 2007a) and Hernández-Molina et al. (2006).

Based on the shipboard biostratigraphic information, the mud-rich interval at 100-170 mbsf at Site U1387 records deposition from $\sim 800$ to $\sim 400 \mathrm{ka}$, slightly younger than the age of the lithologically similar Subunit IB at Site U1386. Further research will be needed to improve correlations of Pleistocene sediments between Sites U1386 and U1387.

\section{Biostratigraphy}

The microfossil content of sediment recovered at Site U1387 was usually high, with the exception of a dolomite layer in Section 339-U1387C-19R-4 and a few lithified sandstone units (see "Lithostratigraphy") that could not be disaggregated. The Pleistocene, upper Pliocene, and uppermost Miocene samples (Fig. F25; Table T5) are very rich in planktonic and benthic foraminifers as well as nannofossils. In the Pleistocene sediments, nannofossils, foraminifers, and ostracods are, in general, moderately to well preserved (Tables T6, T7). In the lower Pliocene, however, most of the calcareous microfossils and nannofossils are corroded and fragmented. Furthermore, a mixture of shallow- and deepwater forms characterizes the benthic foraminifer and ostracod assemblages during this period, supporting deposition characteristic of bathyal settings dominated by gravitational, mainly turbiditic episodes (see "Lithostratigraphy").

Pollen and spores are abundant in the 13 samples analyzed in Holes U1387A and U1387C, ranging from $\sim 4,500$ to 32,500 grains $/ \mathrm{cm}^{3}$. These values are similar to those found at Site U1386. The preservation of the grains is good to moderate in Hole U1387A (upper $350 \mathrm{mbsf}$ ) and very poor in Hole U1387C (350-860 mbsf). In the upper part of Hole $\mathrm{U} 1387 \mathrm{C}$, pollen assemblages are dominated by herbs, mainly Taraxacum-type pollen (Asteraceae and Liguliflorae), whereas corroded conifer pollen dominates the sample at the bottom of the section (Fig. F26). 
Common to rare abundances of pteropods were observed in Samples 339-U1387A-1H-CC through 3HCC (Table T7). All other samples were barren of pteropods. Siliceous microfossils, diatoms, and radiolarians are also present at some levels, such as Samples 339-U1387A-24X-CC, 339-U1387B-24X-CC, and 339-U1387C-29R-CC and 30R-1, 59-60 cm (Tables T7, T8), although diatoms are mainly dissolved and only internal, pyritized molds are preserved.

The sedimentary record recovered at this site was continuous during most of the Pleistocene, but a large hiatus was observed in Core 339-U1387C-19R (Fig. F25; Table T5). Based on the presence of Sphaeroidinellopsis seminulina in Sample 339-U1387C-19R$\mathrm{CC}$, the hiatus may span from 1.8 to at least 3.19 Ma.

Below the hiatus, early Pliocene and latest Miocene sediments were recovered with ages younger than 6.35 Ma for the bottom of Hole U1387C.

Sedimentation rates are $25 \mathrm{~cm} / \mathrm{k} . \mathrm{y}$. in the recovered Pleistocene section and $15 \mathrm{~cm} / \mathrm{k} . \mathrm{y}$. in the Pliocene to latest Miocene sequence.

\section{Calcareous nannofossils}

All core catcher samples from Holes U1387AU1387C were analyzed for calcareous nannofossil biostratigraphy. Additionally, selected samples from Holes U1387A and U1387C were analyzed to constrain biohorizons, paying attention only to marker species. Calcareous nannofossil assemblages are abundant and diverse, and the preservation is good to moderate, with weak dissolution and overgrowth in some samples. Small placolith species $(<3 \mu \mathrm{m})$ dominate most of the assemblages. Inorganic input and reworking of lower Neogene and Paleogene species vary from few to common throughout all sections (Table T6).

In total, 17 Quaternary and Neogene nannofossil datums defined and/or calibrated by Raffi et al. (2006 and references therein) and Flores et al. (2010) were identified in all holes (Table T5).

The change in abundance of the large Emiliania huxleyi $(>4 \mu \mathrm{m})$ that characterizes Termination 1 in midto low-latitude water masses in the Atlantic Ocean has been proven as a useful event by Flores et al. (2010). This change in abundance was recorded between Samples 339-U1387A-1H-2, $105 \mathrm{~cm}$, and 1H$3,75 \mathrm{~cm}$ (2.55-3.75 mbsf), making it possible to distinguish the onset of the Holocene.

The first occurrence (FO) of E. huxleyi (0.26 Ma), which marks the base of Zone NN21, was placed between Samples 339-U1387A-9X-3, $75 \mathrm{~cm}$, and 9X-4, $75 \mathrm{~cm}$ (68.85-70.35 mbsf), and between 339U1387B-6H-CC and 7X-CC (56.10-64.18 mbsf). However, this event should be taken with caution because of dissolution effects and the low proportion of this species. The last occurrence (LO) of Pseudoemiliania lacunosa (0.46 Ma), considered to be a globally synchronous event that defines the top of Zone NN19, occurred between Samples 339-U1387A-13X$6,75 \mathrm{~cm}$, and 13X-7, $33 \mathrm{~cm}(111.75-112.44 \mathrm{mbsf})$, and between 339-U1387B-11X-CC and 12X-CC (104.11-113.54 mbsf).

A biohorizon considered useful in dating Pleistocene sediments is the LO of Reticulofenestra asanoi (0.90 Ma), which was placed between Samples 339U1387A-22X-7, $64 \mathrm{~cm}$, and 22X-CC (198.15-199.20 mbsf) and between 339-U1387B-22X-CC and 23XCC (204.40-214.09 mbsf). The FO of $R$. asanoi (1.07 $\mathrm{Ma})$, another significant event for the Pleistocene, was recorded between Samples 339-U1387A-29X-2, $65 \mathrm{~cm}$, and 29X-3, $65 \mathrm{~cm} \mathrm{(257.9-259.4} \mathrm{mbsf),} \mathrm{and}$ between 339-U1387B-26X-CC and 27X-CC (242.74$243.54 \mathrm{mbsf})$. To define these biohorizons, we considered specimens of $R$. asanoi $\geq 6 \mu \mathrm{m}$ in size.

The LO of large Gephyrocapsa spp. (>5.5 $\mu \mathrm{m})(1.24$ Ma) was recorded between Samples 339-U1387A$31 \mathrm{X}-\mathrm{CC}$ and $32 \mathrm{X}-1,75 \mathrm{~cm}$ (284.81-286.34 mbsf), and between 339-U1387B-30X-CC and 31X-CC (281.30-290.87 mbsf).

The LO of Helicosphaera sellii (1.25 Ma) was identified between Samples 339-U1387A-32X-1, $75 \mathrm{~cm}$, and $32 \mathrm{X}-1,75 \mathrm{~cm}$ (286.34-287.82 mbsf), and between 339-U1387B-31X-CC and 32X-CC (290.87$300.76 \mathrm{mbsf})$. This event is considered diachronous (Raffi et al., 1993; Wei, 1993); however, its occurrence at this site is consistent with the ages provided by Raffi et al. (2006) for the Mediterranean Sea when compared with other calibrated events.

The FO of large Gephyrocapsa spp. (>5.5 $\mu \mathrm{m})(1.61$ Ma) was identified between Samples 339-U1387C7R-CC and 8R-CC (346.05-357.52 mbsf). The LO of Calcidiscus macintyrei (1.66 Ma) is defined in the same interval.

Between Samples 339-U1387C-18R-CC and 61R-CC, the succession of events is complex to establish because of potential reworking linked to the presence of several turbidites and slump deposits within all of Hole U1387C.

Between Cores 339-U1387C-18R and 19R, a variation in the composition of calcareous nannofossil assemblages was recorded, characterized by the presence of Discoaster brouweri, Discoaster pentaradiatus, Discoaster surculus, and Discoaster tamalis. The LOs of these species and/or morphotypes occur between 1.90 and $2.8 \mathrm{Ma}$, allowing us to infer a possible hiatus within Zones NN19 and NN17. However, based on planktonic foraminifer data, the hiatus could be extended at least until 3.19 Ma because of the pres- 
ence of S. seminulina (Table T5). Core 339-U1387C$19 \mathrm{R}$ is characterized by the presence of a dolomiterich layer and, for most of its length, by the absence of calcareous nannofossil assemblages.

The lower portion of Hole U1387C was analyzed by selecting intervals with predominantly fine-grained sediment and trying to avoid possible turbidites and slumps (see "Lithostratigraphy"). The LO of Sphenolithus spp. (3.7 Ma) and Reticulofenestra pseudoumbilicus $>7 \mu \mathrm{m}$ (3.83 ma), marker species of Zone NN14NN15, was recorded between Samples 339-U1387C31R-CC and 33R-CC (573.59-597.01 mbsf). The LO of Amaurolithus primus (4.5 Ma) was recorded between Samples 339-U1387C-39R-CC and 40R-5, 91 $\mathrm{cm}$ (650.36-661.21 mbsf). This last event should, however, be taken with caution because of the low proportion of this species.

The deepest portion of Hole U1387C is characterized mainly by undisturbed hemipelagic deposits (nannofossil mud to nannofossil ooze; see "Lithostratigraphy") allowing the approximation of the LO of Discoaster quinqueramus (Zone NN11-NN12; $5.54 \mathrm{Ma}$ ) between Samples 339-U1387C-55R-CC and 56R-7 (805.68-817.18). This bioevent is placed in the uppermost Miocene, close to the Miocene/Pliocene boundary. Below this interval, the presence of assemblages composed mainly of Discoaster berggrenii, D. quinqueramus, and Discoaster variabilis was recorded. For the deepest portion of the hole, the sparse presence of both Amaurolithus primus and Amaurolithus delicatus, as well as common specimens of Reticulofenestra rotaria and dominance of small placoliths of Reticulofenestra minuta against Reticulofenestra haqii/minutula morphotypes (Young, 1998; Flores and Sierro, 1987), suggest a Messinian age.

\section{Planktonic foraminifers}

Planktonic foraminifers are dominant in the Pleistocene samples from all three holes (Tables T7, T8), with the exception of Sample 339-U1387B-34X-CC. In the Pliocene to latest Miocene samples, abundance varies between rare and dominant. Preservation is generally moderate to very good, but in several samples, especially in the Pliocene, poor preservation was observed.

The Pleistocene assemblages are typical of temperate waters from the North Atlantic with a mixture of surface- and deep-dwelling foraminifers. Globigerina bulloides, Neogloboquadrina pachyderma (dextral), and Globorotalia inflata are the dominant species, with Globorotalia truncatulinoides, Globorotalia scitula, Globorotalia crassaformis, and occasionally Globorotalia hirsuta also contributing to the deep-dwelling fauna.
In the Pliocene to late Miocene samples, subtropical to tropical species such as Globigerinoides trilobus, Globigerina apertura, Globigerina decoraperta, and Globigerinoides extremus are common. In addition, Sphaeroidinellopsis subdehiscens and S. seminulina were observed in several samples from Hole U1387C (Table T8). Specimens of Sphaeroidinellopsis kochi were detected in Samples 339-U1387C-59R-CC and 60RCC. Globorotalia menardii seldom occurs. Rare specimens of Globorotalia conomiozea and Globorotalia miotumida were observed between Samples 339U1387C-57R-CC and 61R-1, 0-3 cm. A reworked specimen of Globorotalia plesiotumida was found in Sample 49R-CC.

N. pachyderma (sinistral) was regularly observed but in low numbers during the middle to late Pliocene. Neogloboquadrina atlantica (dextral) was found in samples from the mid-Pleistocene (see below for details) and Neogloboquadrina atlantica (sinistral) in samples from Cores 339-U1387C-57R through 59R (Table T8). Neogloboquadrina humerosa specimens, on the other hand, were observed between Samples 339U1387C-58R-CC and 61R-CC.

The planktonic foraminifer biostratigraphy at Site U1387 is based on nine events (Table T5). The top of the paracme of $N$. pachyderma (sinistral), (1.21 Ma; Lourens et al., 2004), was placed between Samples 339-U1387A-31X-CC and 32X-CC (284.81-295.29 mbsf) and between 339-U1387B-30X-CC and 31XCC (281.35-290.87 mbsf). The bottom of the paracme of $N$. pachyderma (sinistral) $(1.37 \mathrm{Ma}$; Lourens et al., 2004) was observed between Samples 339U1387B-34X-CC and 36X-CC (319.42-337.99 mbsf) and probably also reached with the lowermost sample in Hole U1387A (i.e., Sample 339-U1387A-38X$\mathrm{CC}$ ).

As at the previous sites, $N$. atlantica (dextral) was observed in samples from the mid-Pleistocene in all three holes: Samples 339-U1387A-33X-CC through 38X-CC (305.05-352.75 mbsf), 339-U1387B-33X-CC through 36X-CC (310.17-337.99 mbsf), continuously between 339-U1387C-2R-CC and 19R-2, 46-48 $\mathrm{cm}$ (299.59-454.98 mbsf), and with a single specimen in 339-U1387C-19R-3, $99 \mathrm{~cm}$, and 19R-CC (458.54-458.59 mbsf).

The FO of Globorotalia inflata (2.09 Ma; Lourens et al., 2004) was placed between Samples 339-U1387C19R-3, 20-22 cm, and 19R-CC (456.22-458.59 mbsf), coinciding with a dolomite-rich layer and the abovementioned hiatus. At the same level, the LO of Globorotalia puncticulata (2.41 Ma; Hilgen, 1991; Lourens et al., 2004) was identified.

Observation of Pliocene events is restricted to Hole U1387C, where discrete samples within specific 
cores were studied in addition to core catcher samples (Table T8). The LO of S. seminulina (3.19 Ma) was also observed between Samples 339-U1387C19R-3, 20-22 cm, and 19R-CC (456.22-458.59 mbsf), coinciding with the FO of $G$. inflata and the LO of G. puncticulata. The co-occurrence of the three aforementioned events with ages from 2.09 to 3.19 Ma together with the recognized nannofossil bioevents indicates a range of $1.9 \mathrm{Ma}$ to at least $3.19 \mathrm{Ma}$ for the hiatus recognized in Core 339-U1387C-19R.

The temporal disappearance of G. puncticulata (3.57 Ma; Lourens et al., 2004) was identified between Samples 339-U1387C-26R-1, 57-59 cm, and 25R-CC (520.24-520.49 mbsf). The reappearance of this species (3.31 Ma) was placed between Samples 22R-CC and 23R-1, 59-61 cm (489.75-492.01 mbsf).

The LO of Globorotalia margaritae (3.8 Ma; Lourens et al. 2004), was recorded between Samples 339U1387C-30R-3, 58-59 cm, and 30R-1, 59-60 cm (558.90-561.89 mbsf). Because the last abundant occurrence of G. margaritae (3.98 Ma) coincides with slumped sediments in Core 339-U1387C-34R (see "Lithostratigraphy"), we did not define this event at this site.

The FO of G. puncticulata (4.52 Ma; Lourens et al., 2004), was observed between Samples 339-U1387C37R-3, 60-62 cm, and 37R-5, 100-102 cm (629.12$632.52 \mathrm{mbsf})$.

The absence of G. miotumida and the presence of $G$. margaritae at the bottom of this site indicate an age younger than 6.35 Ma for the base of Hole U1387C.

\section{Benthic foraminifers}

In Hole U1387A, every second sample between Samples 339-U1387A-1H-CC and 36X-CC was studied for the abundance of benthic foraminifers (Table T9). The assemblages were expected to resemble those of Site U1386. For Hole U1387C, every second core catcher sample was analyzed between Samples 339-U1387C-2R-CC and 28R-CC. Beginning with Sample 29R-CC, all available core catcher samples were included in the analysis. Additionally, selected core catcher samples from Hole U1386B were examined for the "Stilostomella extinction" event. The combined information from all studied samples documents the entire succession recovered at Site U1387.

Abundance and preservation of benthic foraminifers are related to grain size and depositional environment. In the contouritic portions of Hole U1387A (Samples 1H-CC through 36X-CC) and Hole U1387C (Samples 2R-CC through 13R-CC), benthic foraminifers are abundant and preservation is generally good. Within the dolomite horizon and with the occur- rence of turbidite deposition in Core 339-U1387C19R (see "Lithostratigraphy"), the abundant benthic foraminiferal tests are moderately to poorly preserved. Between Samples 339-U1387C-55R-CC and 61R-CC, preservation improves and well-preserved assemblages are found.

Similar to preservation, the composition of the benthic foraminiferal assemblages shows a relation to lithofacies (see "Lithostratigraphy"). Most of the assemblages in the nannofossil ooze and silty mud (Samples 339-U1387A-1H-CC through 36X-CC and 339-U1387C-2R-CC through 18R-CC) consist of species of Brizalina, Bulimina, Cassidulina, Globobulimina, Melonis, Sphaeroidina, and Uvigerina in varying proportions. These taxa characterize upper bathyal environments with increased organic matter flux and reduced ventilation (van Morkhoven et al., 1986; Leckie and Olson, 2003; Murray, 2006). Peak abundances of Brizalina spp. indicate peaks in oxygen depletion of bottom water related to enhanced input of organic matter and/or a well-stratified water column. Transport from the shelf was low, as related taxa occur rarely in the assemblages.

In contrast, Samples 339-U1387A-13X-CC through 19X-CC reveal assemblages primarily composed of Cibicidoides pachyderma and Uvigerina spp., whereas low-oxygen indicators like Brizalina spp. occur sporadically. These assemblages indicate an episode of increased ventilation, which is potentially related to an increase in the intensity of the upper core of MOW. The "epibenthos group," suggested as an indicator for MOW intensity in the area (Schönfeld, 1997, 2002; Schönfeld and Zahn, 2000), shows abundances of $>5 \%$ in this interval, whereas it is less common in the rest of Hole U1387A.

Hyalinea balthica, an indicator for cold-water masses (Bayliss, 1969; van Morkhoven et al., 1986), is only abundant in Samples 339-U1387A-3H-CC and 24XCC and 339-U1387C-3R-CC. As observed at Site U1386, this taxon occurs only sporadically below the MPR marker horizon in the seismic profiles (Llave et al., 2001, 2011; Roque et al., 2012) and disappears below Sample 339-U1387C-7R-CC.

Similar to Site U1386, Cassidulina laevigata/teretis, commonly occurring in boreal waters of the North Atlantic during the middle-late Pliocene and the Pleistocene, virtually disappears below Sample 339U1387C-19R-CC.

The cored portion from Sample 339-U1387C-19R-CC to 43R-CC shows a pattern of alternating assemblages primarily consisting of (1) upper bathyal assemblages characterized by varying amounts of Brizalina, Bulimina, Melonis, Siphonodosaria, and Uvigerina similar to the nannofossil ooze and (2) shelf 
species of Ammonia, Asterigerinata, and Elphidium. The often abraded and broken foraminiferal shells of the later assemblages indicate downslope transport, which is consistent with the sedimentological observations (see "Lithostratigraphy"). Within the assemblages dominated by shelf taxa, a further distinction can be drawn that corresponds well to lithofacies and potentially indicates different sources for the transported sediments. Whereas the core catcher samples from the turbiditic sediment (Samples 339-U1387C-19R-CC through 33R-CC) reveal middle-outer shelf species of Elphidium and Asterigerinata as main components, the inner shelf taxon Ammonia occurs frequently only in the interval of convolute bedding (Samples 38R-CC through 43R-CC).

Benthic foraminiferal assemblages between Samples 339-U1387C-44R-CC and 52R-CC are mainly composed of the shelf taxa Ammonia, Elphidium, and Asterigerinata, as well as cibicids. In particular, Samples 47R-CC through 51R-CC reveal the highest abundances of Cibicides lobatulus in the succession. Together with scarce deepwater taxa, the assemblages imply downslope transport as well as increased ventilation and/or current strength (Schönfeld, 1997).

A shallowing trend and/or a first phase of tectonically driven sediment transport are implied for the lowest part of Hole U1387C. Beginning with Samples 339-U1387C-60R-CC and 61R-CC, the occurrences of Cibicidoides wuellerstorfi and Laticarinina pauperata indicate middle bathyal to abyssal environments (van Morkhoven et al., 1986). These associations are followed by upper bathyal assemblages consisting of Brizalina, Uvigerina, and stilostomellids that finally pass into assemblages increasingly affected by downslope transport with Uvigerina, Cibicidoides, Elphidium, and Ammonia (Samples 339-U1387C-54RCC through 52R-CC).

The Stilostomella extinction (0.58-0.7 Ma) (Hayward, 2002; Kawagata et al., 2005) was recognized between Samples 339-U1387A-14X-CC and 15X-CC (122.99$132.43 \mathrm{mbsf})$ as well as in Samples 339-U1387B-13XCC and 14X-CC (122.45-132.51 mbsf). The datum agrees well with the age estimates from nannoplankton assemblages (Fig. F25). Similar to Site U1386, nodosariids, pleurostomellids, and stilostomellids are rare at this depth interval, and only a few tests have been identified. Frequent occurrences of these foraminiferal groups are recorded from below Sample 339-U1387A-33X-CC.

\section{Ostracods}

Ostracods were examined in most core catcher samples from Hole U1387A and selected core catcher samples from Hole U1387C to provide a low-resolution record of the entire stratigraphic section recov- ered at Site U1387 (0-865 mbsf), which extends from the Holocene to the latest Miocene (Fig. F25). In general, ostracod abundance decreases with increasing depth, but it varies significantly throughout the record, with lowest abundances recorded from $\sim 865$ to $350 \mathrm{mbsf}$. Highest concentrations are observed in the upper 350 mbsf, a section that is distinguished by contourite deposition and good preservation of both benthic foraminifers and ostracods. A marked abundance peak is observed at $\sim 170$ mbsf, which corresponds to $\sim 0.72 \mathrm{Ma}$ according to calcareous nannofossils and planktonic foraminifer biostratigraphy.

The ostracod assemblage found at Site U1387 is similar to that observed at Site U1386 and includes $>70$ species typical of the inner shelf to upper slope facies (Table T10). Species diversity, however, is underestimated because species of selected genera (i.e., Krithe, Cytheropteron, etc.) were grouped to facilitate the shipboard preliminary study. The most common genera are Krithe, Henryhowella, Cytheropteron, Argilloecia, and Cytherella, with lesser contributions by Buntonia, Parakrithe, Aurila, and Urocythereis.

Four main ostracod assemblages were distinguished based on the stratigraphic distribution of the different taxa. Assemblage $\mathrm{A}$ is characterized by Krithe spp., Argilloecia acuminata, Cytheropteron spp., Paracytherois productum, Paramacrocypris arcuata, and Pseudocythere caudata. This assemblage is present during three intervals in the record: in the upper $220 \mathrm{mbsf}$, between 315 and 420 mbsf, and between 820 and 850 mbsf. These taxa characterize upper bathyal environments with increased organic matter flux and reduced ventilation (Cronin, 1983; Ruiz et al., 2008; Alvarez Zarikian et al., 2009).

Assemblage B, characterized by ostracods typical of bathyal environments and enhanced ventilation (Didié and Bauch, 2000; Ruiz et al., 2008; Alvarez Zarikian et al., 2009), dominates at the base of Hole U1387C ( 840-865 mbsf), from $\sim 670$ to $480 \mathrm{mbsf}$ (except a short interval between $\sim 570$ and $600 \mathrm{mbsf}$, see below), and from 345 to 215 mbsf. This assemblage includes Henryhowella sarsii, Cytherella spp., Monoceratina mediterranea, Neonesidea mediterranea, Paijenborchella malajensis cymbula, Parakrithe dimorpha, and Bradleya dictyon.

Assemblage $\mathrm{C}$ is present in the upper $350 \mathrm{mbsf}$ at Site U1387, and its proportion increases to $>50 \%$ in Samples 339-U1387B-1H-CC and 2H-CC (8-15 mbsf). Assemblage C includes Buntonia dertonensis, Buntonia sublatissima, Rectobuntonia inflata, Buntonia textilis, Loxoconcha multifora, and Pterigocythereis jonesii. Today, the majority of these species lives between 75 and 250 mbsl in the Mediterranean Sea (Bonaduce et al., 1975; Yassini, 1979; Ruiz and Gonzalez-Regalado, 
1996) and may indicate a change in bottom water environmental conditions possibly related to bathymetric reduction in the Gulf of Cádiz at this time.

Assemblage D consists of typical shallow-water, inner-shelf taxa Aurila spp., Callistocythere spp., Loxoconcha rhomboidea, Urocythereis spp., and Ruggieria longecarenata (Ruiz et al., 2008). This assemblage was observed only in Samples 339-U1387C-31R-CC through 33R-CC and from 41R-CC to 54R-CC, but their preservation is poor and most specimens are fragmented. These samples correspond to debrite and turbidite layers (see "Lithostratigraphy") of early Pliocene age, and the presence of shallow-water ostracods in these sediments imply reworking by gravity and/or lateral flow. The paleonvironmental interpretation derived from the ostracod fauna is in agreement with that derived from benthic foraminifers at this site.

\section{Palynology}

Five samples from Hole U1387A (1H-CC, 10X-CC, 20X-CC, 29X-CC, and 37X-CC) and eight samples from Hole U1387C (7R-CC, 10R-CC, 19R-CC, 21RCC, 24R-CC, 35R-CC, 48R-CC, and 61R-CC) were analyzed. The lithology of the four uppermost samples in Hole U1387A is dominated by mud (silty mud and nannofossil mud). In contrast, the sample at the base of Hole U1387A is different, formed by silty sand (see "Lithostratigraphy"). Pinus is well represented in the upper $350 \mathrm{~m}$ of the sequence, with the maximum abundance at the top (Fig. F26; Table T11). It is almost absent in all the samples from Hole U1387C, although some of the corroded pollen of conifers likely belong to the Pinus genus.

In Hole U1387A, the pollen assemblages in Samples 339-U1387A-1H-CC, 10X-CC, 20X-CC, and 29X-CC, covering the last $1 \mathrm{~m} . \mathrm{y}$. , are characterized by assemblages from the Mediterranean forest, mainly deciduous and evergreen Quercus and Olea, semidesert environments (Artemisia, Ephedra, and Chenopodiaceae/Amaranthaceae), and grasslands, mainly Taraxacum-type and Poaceae, similar to the composition found in the contemporaneous levels of the previous sites (see "Biostratigraphy" in the "Site U1385" chapter [Expedition 339 Scientists, 2013c] and "Biostratigraphy" in the "Site U1386" chapter [Expedition 339 Scientists, 2013d]). In contrast, the silty sand sample at the bottom of Hole U1387A-37X-CC, dated close to $1.6 \mathrm{Ma}$, contains two distinct assemblages, one composed of well-preserved tree pollen grains (deciduous and evergreen Quercus, Olea, Carpinus orientalis/Ostrya, Ulmus/Zelkova, and Taxodiaceae/Cupressaceae) and the other characterized by corroded pollen grains, mainly $\mathrm{Ta}$ raxacum-type and conifers, suggesting two different sources of pollen grains. Well-preserved tree pollen might be transported by a river plume from the adjacent landmass of southern Iberia, whereas the corroded pollen and the associated coarse-grain size sediments might be the result of reworked material caused by downslope or alongslope flow (see "Lithostratigraphy").

In Hole U1387C, all analyzed samples are composed of light (greenish gray nannofossil mud) and dark (very dark greenish gray mud with biogenic carbonates) mud (see "Lithostratigraphy") dated older than 1.61 Ma (Table T5). Pollen grains are poorly preserved, and the unidentifiable/total pollen and spores ratios are the highest of the sequence. Samples 339-U1387C-7R-CC, 10R-CC, 19R-CC, 21R-CC, 24R-CC, and 35R-CC are dominated by Taraxacumtype, a pollen that is very resistant to corrosion and, additionally, easily to identify when damaged. This pollen morphotype is commonly overrepresented in poorly preserved pollen assemblages (e.g., Sánchez Goñi, 1994). In contrast, Samples 339-U1387C-48RCC and 61R-CC are dominated by corroded pollen grains of conifers. High proportions of unidentifiable conifer pollen are a common feature in Pliocene and Miocene sequences of southern Iberia (JiménezMoreno et al., 2010). The fact that no well-preserved pollen assemblages are recorded in sediments older than 1.6 Ma could indicate a different regional geomorphological configuration at that time that precluded any direct arrival of pollen from the local vegetation of the close continent.

\section{Paleomagnetism}

Paleomagnetic investigation of the 130 APC, XCB, and RCB cores (excluding one empty core in Hole U1387B and one wash core, two empty cores, and two short $(<45 \mathrm{~cm})$ cores in Hole U1387C) collected at Site U1387 included the measurement of magnetic susceptibility of whole-core and archive-half splitcore sections and the natural remanent magnetization (NRM) of archive-half split-core sections. NRM was measured before and after alternating field (AF) demagnetization with $20 \mathrm{mT}$ peak field for all studied cores of the site. In addition, Cores 339-U1387C$54 \mathrm{R}$ through $61 \mathrm{R}$ were measured after AF demagnetized with peak fields $10,20,25$, and $30 \mathrm{mT}$. The FlexIt tool was successfully used to orient five cores in the APC section of Holes U1387A and U1387B starting with Core $4 \mathrm{H}$ (Table T12). Stepwise AF demagnetization of 32 selected discrete samples was performed at successive peak fields of $0,5,10,15,20$, $25,30,35,40,45,50,55,60,70$, and $80 \mathrm{mT}$ to verify the reliability of the split-core measurements and to determine the magnetostratigraphy in the strongly 
overprinted and disturbed XCB- and RCB-cored sections. The depth levels from which the measured discrete samples were taken are indicated by blue triangles in the first panel of Figure F25. We processed data extracted from the Laboratory Information Management System database by removing all measurements collected from disturbed and void intervals, which are listed in Table T13 (see "Stratigraphic correlation"), and all measurements that were made within $10 \mathrm{~cm}$ of the section ends, which are slightly biased by measurement edge effects. The processed NRM inclination, declination, and intensity data after $20 \mathrm{mT}$ peak field AF demagnetization are listed in Table T14, T15, and T16.

\section{Natural remanent magnetization and magnetic susceptibility}

The intensity of NRM after $20 \mathrm{mT}$ demagnetization is similar in magnitude in the overlapping parts of Holes U1387A, U1387B, and U1387C, ranging from $\sim 10^{-5}$ to $\sim 10^{-2} \mathrm{~A} / \mathrm{m}$ (Fig. F27, third panel). The uppermost $~ 92$ mbsf exhibits the highest NRM intensities, on the order of $10^{-2} \mathrm{~A} / \mathrm{m}$. Below this level, NRM intensity drops one to three orders of magnitude, in the range of $\sim 10^{-5}$ to $\sim 10^{-3} \mathrm{~A} / \mathrm{m}$.

Despite the significant coring disturbance and drill string overprint in the $\mathrm{XCB}$ - and $\mathrm{RCB}$-cored sections, a relatively stable magnetic component was preserved in sediments from all three holes that allows for the determination of magnetic polarity for some parts of the recovered sediment sequences. A magnetic overprint with steep positive inclinations, which was probably acquired during drilling, was usually removed by up to $20 \mathrm{mT}$ peak field AF demagnetization (Fig. F28). The uppermost few ( 6) XCB cores in both Holes U1387A and U1387B appear to be less disturbed, and the NRM directions are less affected (Fig. F27). XCB sections from deeper parts of the holes are often heavily biscuited and usually contain as much of the disturbed matrix as the intact material, strongly compromising the quality of the resulting paleomagnetic data. Only discrete samples taken from the biscuits will enable the extraction of a better-quality paleomagnetic signal. The RCB cores from Hole U1387C exhibit a relatively well preserved magnetic polarity record downhole to $\sim 450$ mbsf. Below this depth, weak NRM intensity combined with a significant overprint severely compromises the quality of the magnetic signal.

The AF demagnetization behavior of eight discrete samples from normal and reversed polarity intervals is illustrated in Figure F28. All samples exhibit a steep, normal overprint that was generally removed after AF demagnetization at peak field of $\sim 15-20 \mathrm{mT}$, demonstrating that the $20 \mathrm{mT}$ magnetic cleaning level is, in general, sufficient to eliminate the overprint. The samples also appear to acquire a significant amount of anhysteretic remanent magnetization at high peak field ( $>55 \mathrm{mT}$ ) AF demagnetization steps, possibly because of bias caused by ambient magnetic field during demagnetization. We calculated component NRM directions of the discrete samples from data from the 25-50 mT demagnetization steps using principal component analysis (Kirschvink, 1980) and the UPmag software (Xuan and Channell, 2009). Component inclinations of discrete samples with maximum angular deviation less than $\sim 15^{\circ}$ are shown as yellow circles in Figure F27 (first panel).

Magnetic susceptibility measurements were made on whole cores from all three holes as part of the Whole-Round Multisensor Logger (WRMSL) analysis and on archive-half split-core sections using the Section Half Multisensor Logger (SHMSL) (see "Physical properties"). Magnetic susceptibility is consistent between the two instruments and, in general, parallels the intensity of magnetic remanence. The WRMSL-acquired susceptibility was stored in the database in raw meter units. These were multiplied by a factor of $0.68 \times 10^{-5}$ to convert to the dimensionless volume SI unit (Blum, 1997). A factor of $(67 / 80) \times$ $10^{-5}$ was multiplied by the SHMSL-acquired susceptibility stored in the database. Magnetic susceptibility varies between $5 \times 10^{-5}$ and $40 \times 10^{-5}$ SI (Fig. F27, fourth panel). Note that in Figure F27, a constant of $25 \times 10^{-5}$ SI was added to the SHMSL measurements (gray lines) to facilitate the comparison with the WRMSL measurements (black lines).

\section{Magnetostratigraphy}

The lack of core orientation and the significant coring disturbance and drill string overprint in the XCB and RCB cores limit our magnetostratigraphic interpretation to rely entirely on changes in NRM inclination and on measurements of discrete samples taken from the relatively undisturbed drilling biscuits. The geomagnetic field at the latitude of Site U1387 $\left(36.81^{\circ} \mathrm{N}\right)$ has an expected inclination of $56.25^{\circ}$, assuming a geocentric axial dipole field model, which is sufficiently steep to determine magnetic polarity in cores that lack horizontal orientation.

The Brunhes-Matuyama polarity transition is constrained by discrete samples and occurs in Hole U1387A between 182 mbsf (Sample 339-U1387A21X-2W, 72-74 cm) and 207 mbsf (Sample 23X-6W, 61-63 cm) (Fig. F28). A discrete sample from 192.17 mbsf in Hole U1387A (Sample 22X-3W, 64-66 cm) appears to carry an intermediate NRM inclination 
(Figs. F27, F28). We therefore place the Brunhes/Matuyama boundary at 190 mbsf in Hole U1387A. Our best estimate for the position of the Brunhes-Matuyama transition in Hole U1387B at 192 mbsf is based on comparison with the general inclination pattern in Hole U1387A and the occurrence of negative inclinations at this depth. The relatively large scatter of the remanent directions in the XCB cores made it difficult to determine the exact position of the boundary; however, more detailed paleomagnetic work on discrete samples from drilling biscuits should resolve the transition relatively well. The top and bottom of the Jaramillo Subchron (C1r.1n) cannot be determined in any of the three holes based on the core-section measurements or the limited number of discrete sample measurements. The top of the RCB-cored section of Hole U1387C records the lower part of the Matuyama Chron (C1r.2r) and, surprisingly well, the top of the Olduvai Chron (C2n) at $\sim 412.5$ mbsf. This interpretation is supported by at least two discrete sample measurements that yielded relatively stable characteristic remanent magnetizations. Discrete samples from $370.51 \mathrm{mbsf}$ (Sample 339-U1387C-10R-3W, 70-72 cm) and $447.12 \mathrm{mbsf}$ (Sample 18R-3W, 71-73 cm) clearly carry reversed and normal magnetization, respectively (Figs. F27, F28). The core-section inclination (after $20 \mathrm{mT}$ peak AF demagnetization) exhibits a clear normal polarity pattern between $\sim 412.5$ and $\sim 450$ mbsf, but the onset of the Olduvai Chron (C2n) is obliterated by low magnetic intensities combined with coring disturbances and a strong coring-induced overprint. Below $\sim 450$ mbsf, magnetostratigraphic interpretation is not possible, and even discrete samples can rarely resolve reliable paleomagnetic information.

\section{Physical properties}

Physical properties at Site U1387 were determined in Holes U1387A, U1387B, and U1387C. High-resolution scanning at $2.5 \mathrm{~cm}$ intervals on whole-round segments was performed on the WRMSL. The Special Task Multisensor Logger (STMSL) was only used for Hole U1387B for stratigraphic correlation purposes. NGR scanning was performed on all cores of Site U1387 at low resolution ( $20 \mathrm{~cm}$ intervals) with one position of the detector array. Thermal conductivity probes were applied on Section 2 or 3 in Cores 339U1387A-1H through $6 \mathrm{H}$ because of the switch to XCB coring at 47.7 mbsf. Reasonable $P$-wave velocities were obtained on the WRMSL only in Hole U1387A until Core $6 \mathrm{H}$ and on split-core segments (working half) in Hole U1387A for every section in the upper 50 mbsf and in some lithified parts in Hole U1387C (Cores 339-U1387C-19R and 43R through
50R). Moisture and density were determined for every second section of each core on Hole U1387A and downhole below Core 339-U1387C-8R. Color reflectance and split-core point-magnetic measurements were made for every segment at $5 \mathrm{~cm}$ intervals.

Based on these physical properties, four main intervals were identified. The first change occurs at Site $\mathrm{U} 1387$ at $50 \mathrm{mbsf}$, above which high values of magnetic susceptibility, gamma ray attenuation (GRA) density, NGR, and the spectral reflectance component $\mathrm{a}^{*}$ are recorded (physical properties Unit I; Figs. F29, F30). Below this depth downhole to 220 mbsf, a second interval is characterized by a persistent positive correlation between GRA density, NGR, magnetic susceptibility, and spectral reflectance components $\mathrm{a}^{*}$ and $\mathrm{L}^{*}$. In particular between $\sim 50$ and 100 mbsf, trends as well as superimposed fluctuations agree very well between these parameters. Below 100 mbsf, the positive correlation between all studied physical properties remains, except that $\mathrm{L}^{*}$ trends start to correlate negatively with the rest of the studied parameters (physical properties Unit II; Figs. F29, F30). A third interval is defined between 220 and $\sim 460$ mbsf, characterized by variable correlations between the studied parameters. Particularly notable is the occurrence of more distinct decimeter- to meterscale cycles, high fluctuations in $\mathrm{L}^{*}$, and mostly low magnetic susceptibility values (physical properties Unit III; Figs. F29A, F30A). The discontinuity previously defined by Llave et al. (2001, 2007a, 2011) and Hernández-Molina et al. (2006) as the mid-Pleistocene revolution discontinuity (MPR) and as Heinrich Event H4 by Roque et al. (2012) at this site appears to be approximately between 198 and 230 mbsf. Therefore, there seems to be a good correlation between major unconformities and cyclical changes in the lithology reflected by physical properties, but further detailed work is required for confirmation. The fourth interval was differentiated downhole from $\sim 460$ mbsf to the base of Hole U1387C, where in spite of poor recovery the most remarkable feature is that NGR is more positively correlated to GRA density and negatively correlated to $\mathrm{L}^{*}$ and, albeit less pronounced, a* (Figs. F29, F30). The identified hiatus at $\sim 460$ mbsf (see "Lithostratigraphy"), coincident with this third change in physical properties and lithology, indicates a transition from a mixed turbidite-contourite system with the presence of slumps below 460 mbsf to a more contouritic system above. Elevated GRA density, NGR, and magnetic susceptibility values are observed below $800 \mathrm{mbsf}$, where they are often correlated, although not consistently, to the presence of sandstones in the sediment (Figs. F29B, F30B). 


\section{Whole-Round Multisensor Logger and Special Task Multisensor Logger measurements}

The STMSL was not used for Hole U1387A because no immediate acquisition of data for stratigraphic correlation was necessary, but the STMSL was used for Hole U1387B. Temperature equilibration before starting with the WRMSL was at least $3 \mathrm{~h}$.

\section{Gamma ray attenuation density}

WRMSL GRA density data at Site U1387 is highly variable between 1.6 and $2.2 \mathrm{~g} / \mathrm{cm}^{3}$ (Fig. F29). Some of the observed scatter is due to incomplete filling of liners, especially in sandy sections and cores to which the more destructive $\mathrm{XCB}$ and $\mathrm{RCB}$ drilling techniques were applied. Cores taken using the RCB (Hole U1387C), furthermore, show low GRA densities compared to those taken with the APC and XCB (Holes U1387A and U1387B), caused by lesser volume of the actual sediment recovered. Thus, GRA density in Hole U1387 is particularly biased by core recovery. This is also evident from the continuously underestimated GRA density with respect to bulk density determined on discrete samples, especially in parts of Hole U1387C with poor recovery (Fig. F29).

In general, the GRA density record reflects variations in sand content of the sediment and its texture. An uppermost interval from 0 to 50 mbsf can be distinguished by two distinct GRA density peaks ranging from 2.1 to $1.6 \mathrm{~g} / \mathrm{cm}^{3}$. The high densities in the upper interval of Site U1387 mainly correspond to intervals rich in sandy beds and silty mud. Below a minimum in GRA density of $1.6 \mathrm{~g} / \mathrm{cm}^{3}$ at $\sim 50 \mathrm{mbsf}$, density increases until $\sim 250$ mbsf with no general increase below this depth. GRA densities oscillate between 1.7 and $\sim 2.1 \mathrm{~g} / \mathrm{cm}^{3}$ throughout the entire record. The highest GRA densities in this interval correspond to a dolostone (Core 339-U1387C-19R), debrites, slumps, and well-cemented sandstones. Otherwise, a complex relation to grain size is observed. Sandy silty layers show high values in GRA density, NGR, and magnetic susceptibility (Section 339-U1387C-2R-5); however, sandy layers often have low values of magnetic susceptibility and NGR but high GRA density. In other cases, low values of magnetic susceptibility, NGR, and GRA density are identified (Section 339-U1387C-5R-5). This indicates that the compositions are a variable mixture of contourites and turbidites, particularly with regard to the abundance of calcareous material, with no clear distinction possible between the two sedimentary facies.

\section{Magnetic susceptibility}

Based on WRMSL data, magnetic susceptibility increases in the upper 20 mbsf at Site U1387, with maximum values at $20 \times 10^{-5}$ SI (Fig. F29A). At 30-50 mbsf, a divergence between magnetic susceptibility and GRA density becomes apparent in that GRA density has a second maximum, whereas magnetic susceptibility remains at an intermediate level. Magnetic susceptibility is rather low $\left(10 \times 10^{-5}\right.$ to $\left.20 \times 10^{-5} \mathrm{SI}\right)$ below $\sim 100$ mbsf with some peaks that become less abundant below $\sim 320$ mbsf, except between 800 and 820 mbsf where there are slightly higher values. The cyclic fluctuations in magnetic susceptibility presumably record alternating beds that are richer in either biogenic or siliciclastic components. The downhole decrease in signal strength is possibly due to diagenetic degradation of magnetic properties. The lowermost part of Hole U1387C is dominated by turbidites, slumps, and $20 \mathrm{~m}$ of lithified sandstone, correlating with the observed high values in magnetic susceptibility in this interval.

WRMSL and split-core magnetic susceptibility data agree relatively well for APC cores. For sediments retrieved using the XCB or RCB, WRMSL values are consistently lower and the split-core magnetic susceptibility values have considerable scatter. We assume that this can be attributed to the incomplete filling of the liner for those cores, providing less volume for sensor loop integration, as well as the fracturing and biscuiting of the material that particularly affects the split-core measurements.

\section{P-wave velocity}

Sonic velocities were measured with the WRMSL for Hole U1387A, and an attempt was made to determine $P$-wave velocities on split cores in each section of Holes U1387A and U1387C (Fig. F29). Because of poor sediment-to-liner coupling, reasonable results from the WRMSL could only be obtained for the upper $\sim 45$ mbsf. Although the sediment surface appeared to be smooth and should have provided adequate coupling to the transducers on split cores, no clear acoustic signal could be obtained for $P$-wave velocity determinations at greater depth. An explanation for this might be the relatively stiff and brittle nature of the sediment, which promotes the formation of small cracks that negatively affect signal propagation.

$P$-wave velocity measured with the WRMSL follows the trend of increasing GRA density in the upper 30 mbsf, with values of $1450-1500 \mathrm{~m} / \mathrm{s}$ in the uppermost intervals, almost $1700 \mathrm{~m} / \mathrm{s}$ between 10 and 20 mbsf, and a decrease to $1400-1570 \mathrm{~m} / \mathrm{s}$ at $20-30$ mbsf (Fig. F29A). The increase in GRA density be- 
tween 30 and $\sim 50$ mbsf is not well covered by the WRMSL record but can be traced with the split-core data (only accounting for automatically processed data). Both types of measurement agree well, especially when only considering split-core data with high signal quality.

In Hole U1387C, some discrete specimens of lithified rock were analyzed. In the dolomite-cemented interval in Core 339-U1387C-19R, a $P$-wave velocity of $2590 \mathrm{~m} / \mathrm{s}$ was determined, whereas the indurated sandstones found in Cores 44R through 50R have values between 3500 and $5600 \mathrm{~m} / \mathrm{s}$ (Fig. F29). Sonic velocities $>5000 \mathrm{~m} / \mathrm{s}$ correspond to a sandstone layer, mainly composed of carbonate cement with bioclasts.

\section{Natural gamma radiation}

The upper part of Hole U1387A reveals high NGR values (35-50 cps) followed by minimum values of $\sim 30$ cps at $\sim 50$ mbsf. Below this depth, NGR gradually increases to peak values of $60 \mathrm{cps}$ with superimposed fluctuations. A notable positive correlation of NGR with GRA density, magnetic susceptibility, and $\mathrm{a}^{*}$ exists above 220 mbsf (Fig. F30A). From 220 to 650 mbsf, NGR values correlate inversely to GRA density and $\mathrm{a}^{*}$ but positively to magnetic susceptibility. Below 650 mbsf, the cyclicity of NGR values shows a positive correlation to magnetic susceptibility, GRA density, and $a^{*}$. The varying nature of the correlation between the different physical properties indicate that changes in the depositional style and sediment source are affecting the mineralogical composition of the sediments.

\section{Moisture and density}

Determination of moisture and density on discrete sediment samples was performed on every second section of each core in Hole U1387A (Fig. F31). Sampling was preferably carried out on the dominant lithology of a section, avoiding small interlayers of differing grain size (e.g., centimeter-scale sand layers). Porosity and moisture content generally run in parallel, both decreasing downhole until the sandstone-bearing interval (Cores 339-U1387C-43R through 47R) is reached. This decrease is more obvious in Hole U1387A, with values of 23\%-32\% (moisture content) and $44 \%-56 \%$ (porosity) at the top and $18 \%-24 \%$ and $37 \%-47 \%$,respectively, at the base of the hole. In Hole U1387C, moisture content and porosity only slightly decrease to $16 \%-25 \%$ and $35 \%-$ 47\% (Fig. F31). Interestingly, the dolomite-cemented interval in Core 339-U1387C-19R, itself characterized by low moisture content and porosity, is not related to any change in the general trends. The sandstone beds in Cores 339-U1387C-43R through 47R are low in porosity and moisture content, as expected for well-cemented sandstone. They also seem to represent a boundary below which no decreasing trends in porosity or moisture content are discernible. Slightly above the sandstones, in Cores 339U1387C-38R through 40R, lower porosities are found in sandy intervals, indicating that some degree of cementation occurred in these intervals as well. The somewhat cyclic pattern of moisture and porosity fluctuations continues farther downhole without clear evidence of a relation to grain size variation described in the lithostratigraphy.

Grain density varies mostly between 2.7 and 2.85 $\mathrm{g} / \mathrm{cm}^{3}$ at Site U1387. The upper $\sim 140 \mathrm{mbsf}$ is somewhat exceptional because grain densities are commonly $<2.81 \mathrm{~g} / \mathrm{cm}^{3}$ (Fig. F31A). Also, occasional samples from 340-390 and 740-790 mbsf had high grain densities. The admixture of calcareous material might explain the high density in these cases.

\section{Thermal conductivity}

Thermal conductivity was measured once per core using the full-space probe, usually close to the middle of Section 3, in Cores 339-U1387A-1H through $6 \mathrm{H}$ (see "Downhole measurements"). Cores retrieved using the XCB and RCB were affected by cracks and voids, producing unreliable thermal conductivity measurements; therefore, no measurements are reported from these cores. The results show a decrease from values close to $1.7 \mathrm{~W} /(\mathrm{m} \cdot \mathrm{K})$ at the top of Hole U1387A to $1.3 \mathrm{~W} /(\mathrm{m} \cdot \mathrm{K})$ at $\sim 45 \mathrm{mbsf}$. Thermal conductivity often follows reduced porosity and water content of the sediment, as observed for Site U1386. However, in the case of Site U1387 the direct comparison of conductivity to both moisture content and porosity does not convincingly confirm this pattern. The coarse spatial resolution of the measurements and the variable lithology might explain this lack of correlation to a certain extent; however, other as yet unknown factors might influence thermal conductivity as well.

\section{Summary of main results}

Based on physical property data, four main units were identified, commonly related to boundaries between the defined lithologic units and subunits. The upper part of Site U1387 to $50 \mathrm{mbsf}$ (physical properties Unit I) is characterized by high magnetic susceptibility, GRA density, NGR, and a* values.

Between 50 and 220 mbsf (physical properties Unit II), physical properties show pronounced cyclicity and a positive correlation between physical properties, except $L^{*}$, which is negatively correlated with the rest of the studied parameters. A third unit 
(physical properties Unit III) is defined between 220 and $\sim 460$ mbsf, characterized by variable correlations between the studied parameters. Physical properties Unit IV is differentiated downhole from $~ 460$ mbsf to the base of the Hole U1387C. Although affected by poor recovery, the most notable feature of the latter interval is that NGR is positively correlated to GRA density and negatively to $L^{*}$ and, albeit less pronounced, $a^{*}$. The upper two intervals reflect a good correlation between physical properties, lithology, and cyclical climatic changes.

\section{Geochemistry Volatile hydrocarbons}

Headspace gas analysis was performed as a part of the standard protocol required for shipboard safety and pollution prevention monitoring. In total, 37 headspace samples from Hole U1387A and 49 headspace samples from Hole U1387C (sampling resolution of one per core) were analyzed (Fig. F32; Table T17), spanning the entire depth range of the site. In Hole U1387A, methane $\left(C_{1}\right)$, ethane $\left(C_{2}\right)$, and ethene $\left(\mathrm{C}_{2=}\right)$ were detected. Methane ranges from $6.3 \mathrm{ppmv}$ near the surface to a maximum of $41,831 \mathrm{ppmv}$ at 50.7 mbsf (Section 339-U1387A-7X-3). At the base of Hole U1387A, methane is 6,432 ppmv. Both ethane and ethene were detected from the uppermost core of this hole, but concentrations remain low. Ethane remains $<2.5 \mathrm{ppmv}$ and ethene reaches a maximum of $1.3 \mathrm{ppmv}$ for the entire $351.8 \mathrm{~m}$ of Hole U1387A.

In Hole U1387C, methane is 5,206.3 ppmv at 353.6 mbsf and 10,042.8 ppmv at the base of the hole at 865 mbsf, with a maximum of $17,762.2 \mathrm{ppmv}$ at 814 mbsf (Section 339-U1387C-56R-5). In Hole U1387C, ethene does not exceed $4.5 \mathrm{ppmv}$ and generally stays at concentrations less than $\sim 1 \mathrm{ppmv}$, whereas ethane does not exceed 20 ppmv. Propane was detected in Cores 339-U1387C-33R, 45R, and 55R at concentrations of $8.73,6.52$, and 18.4 ppmv, respectively.

\section{Sedimentary geochemistry}

Sediment samples were collected for analysis of solid-phase geochemistry (inorganic and organic carbon) at a resolution of approximately one sample per core in Holes U1387A and U1387C (Table T18), thereby spanning the full depth of the site. $\mathrm{CaCO}_{3}$ varies from 12 to $38 \mathrm{wt} \%$, with two samples in Hole U1387C with much higher values (Fig. F33). At 457.8 mbsf, $\mathrm{CaCO}_{3}$ reaches $78.6 \mathrm{wt} \%$, which corresponds to a dolomite layer in the core (see "Lithostratigraphy"). The other sample with high $\mathrm{CaCO}_{3}$ (71.7 wt\%) occurs at 693.2 mbsf (Section 339U1387C-44R-1) and corresponds to an interval de- scribed as sandstone (see "Lithostratigraphy"). Organic carbon varies between 0.5 and $1.15 \mathrm{wt} \%$ (Fig. F34A) downhole to $351 \mathrm{mbsf}$ in Hole U1387A and between 0.35 and $2.38 \mathrm{wt} \%$ in Hole U1387C between 356.4 and 863.3 mbsf, with one peak of 3.75 wt $\%$ at 703.3 mbsf.

Nitrogen (Fig. F34B) was measured downhole to 351 mbsf in Hole U1387A and between 356.4 and 863.3 mbsf in Hole U1387C. Measured nitrogen ranges from 0.04 to $0.19 \mathrm{wt} \%$, with one sample in Section 339-U1387C-45R-1 having very low values ( $0 \mathrm{wt} \%)$. This low nitrogen sample also corresponds to a sharp peak in total organic carbon, causing a peak in the $\mathrm{C} / \mathrm{N}$ ratio. The $\mathrm{C} / \mathrm{N}$ ratio, used to distinguish the origin of organic matter (marine versus terrestrial) in the sediments (Emerson and Hedges, 1988; Meyers, 1997), indicates that the organic carbon is mainly of marine origin with a terrestrial component for the uppermost $\sim 350 \mathrm{mbsf}$ and of increasingly terrestrial origin below (i.e., older than 1.6 Ma; see "Biostratigraphy"). Total organic carbon and $\mathrm{C} / \mathrm{N}$ ratios track each other well. Between 322 and 356 mbsf, a change occurs in the nature of organic input. The terrestrial component gains importance and dominates the signal, and additionally there is an increase in the $\mathrm{C} / \mathrm{N}$ variability (Fig. F34C; Table T18). A similar trend is also observed in the pollen data from this site (see "Biostratigraphy"). Furthermore, abrupt changes are apparent in the calculated $\mathrm{C} / \mathrm{N}$ signal at depths coinciding with the position of several hiatuses ( 460, $\sim 630$, and $\sim 730 \mathrm{mbsf})$ and lithostratigraphic changes (see "Lithostratigraphy"). The inferred terrestrial input could have potentially been even larger, but degradation of organic matter with time would have decreased the $\mathrm{C} / \mathrm{N}$ ratio because nitrogen compounds are typically more labile (Ruttenberg and Goñi, 1997).

\section{Interstitial water chemistry}

\section{Major cations and anions}

Whole-round samples were taken for interstitial water analysis at a resolution of one per core from Hole U1387A downhole to 350 mbsf. We did not take interstitial water samples below 350 mbsf because of severe biscuiting of the XCB cores and drill water contamination of the interstitial whole rounds during RCB drilling.

Sulfate concentrations drop markedly in the uppermost part of Hole U1387A from $19.3 \mathrm{mM}$ at $4 \mathrm{mbsf}$ to $0 \mathrm{mM}$ at $12.5 \mathrm{mbsf}$ (Fig. F35A; Table T19), indicating very high rates of sulfate reduction at this site with high sediment accumulation rates. Alkalinity is elevated in the upper $12.5 \mathrm{mbsf}$, averaging 8-10 $\mathrm{meq} / \mathrm{L}$, and decreases to $\sim 4.1 \mathrm{meq} / \mathrm{L}$ at $72 \mathrm{mbsf}$ (Fig. F35B). Alkalinity then increases slightly again to 5.9 
meq/L at 140 mbsf, after which it decreases and averages $\sim 4 \mathrm{meq} / \mathrm{L}$ downhole to the base of the hole. Ammonium concentrations increase three-fold in the upper $32 \mathrm{mbsf}$ and continue to rise to the base of Hole U1387A (Fig. F35C).

The sulfate-methane transition (SMT) is marked by sulfate depletion at $12.5 \mathrm{mbsf}$ and a sharp increase in methane between 14 and 24 mbsf (Fig. F35D). Methane reaches peak concentrations of 41,800 ppmv at $51 \mathrm{mbsf}$, decreases to $5,400 \mathrm{ppmv}$ at $130 \mathrm{mbsf}$, and fluctuates but remains below $10,000 \mathrm{ppmv}$ to the base of the hole.

Calcium concentrations are $8 \mathrm{mM}$ at the surface and decrease rapidly to a minimum of $4 \mathrm{mM}$ at $12.5 \mathrm{mbsf}$ (Fig. F36A; Table T19). From 12.5 mbsf to the base of the hole, calcium concentration increases. Magnesium concentration decreases from a surface value of 52 to $\sim 30 \mathrm{mM}$ at $32 \mathrm{mbsf}$ and remains relatively unchanged to the base of Hole U1387A (Fig. F36B). Potassium decreases gradually downhole from $11 \mathrm{mM}$ near the surface to $\sim 6 \mathrm{mM}$ toward the base of the hole (Fig. F36C). Sodium concentrations vary between 430 and $515 \mathrm{mM}$, with a single peak at 168 mbsf (Fig. F36D). The peak in sodium shows up as an aberration of smaller magnitude in the potassium, magnesium, and calcium profiles (Fig. F36A-F36C) and may be simply due to dilution error during sample preparation for measurement.

Chloride concentrations decrease downhole from $582 \mathrm{mM}$ near the surface to $570 \mathrm{mM}$ at $23 \mathrm{mbsf}$. Below 23 mbsf, chloride concentrations are scattered around $570 \mathrm{mM}$ (Fig. F37; Table T19). Sodium to chloride ratios are all near the seawater value of 0.86 .

The interpretation of the major element interstitial water profiles at Site U1387 is similar to that of Site U1386. High rates of organic matter accumulation have resulted in a very shallow sulfate reduction zone and SMT. The decline in calcium and magnesium in the upper $\sim 20 \mathrm{mbsf}$ is explained by precipitation of dolomite, which occurs near the SMT as a result of increased alkalinity related to sulfate reduction and anaerobic methane oxidation. Elimination of sulfate also reduces ion pairing between sulfate and magnesium, thereby removing a kinetic barrier to dolomite formation.

\section{Minor elements}

Strontium and barium have similar patterns of increasing concentrations downhole (Fig. F38A, F38B; Table T19), whereas boron shows an inverse pattern and generally decreases downhole (Fig. F38C). Silicon concentrations range between 100 and $300 \mu \mathrm{M}$ in the upper part of Hole U1387A (Fig. F38D). Iron and manganese are below detection limits in the ma- jority of the core. Calcium, strontium, and barium are positively correlated, suggesting they are controlled by similar processes, namely carbonate diagenesis (Fig. F39).

\section{Speculation on the origin of the dolomite layers}

The dolostone layers found at $\sim 460 \mathrm{mbsf}$ are a geochemical curiosity. Although we did not take interstitial water samples from below 350 mbsf because of severe XCB biscuiting, the upper interstitial water profile permits us to speculate upon its origin. A key feature is the association of the dolostone with a hiatus from 1.8 to at least $3.19 \mathrm{Ma}$ (see "Biostratigraphy"). We suggest the unconformity represents, at least in part, a period of halted deposition, which resulted in the interface between sulfate reduction and methanogenesis remaining relatively stationary in the sediment column for an extended period of time. Dolomite forms at the SMT and complete layers can develop if the sulfate-methane interface stays at a fixed depth for a prolonged amount of time (Moore et al., 2004; Meister et al., 2008).

\section{Summary}

The observed interstitial water profiles at Site U1387 are very similar to those at Site U1386, which is only $\sim 100 \mathrm{~km}$ away. This suggests that bottom water conditions and sedimentation histories have been similar for the time period represented by the uppermost several hundred meters of both sites.

\section{Downhole measurements}

\section{Logging operations}

Downhole logging measurements in Hole U1387C were made after completion of RCB coring to a total depth of $870 \mathrm{~m}$ drillers depth below seafloor (DSF). In preparation for logging, a wiper trip was run (28 $\mathrm{m}$ of soft fill was found at the bottom of the hole), the hole was flushed with a $50 \mathrm{bbl}$ sweep of high-viscosity mud, and the RCB bit was released. The hole was then displaced with $290 \mathrm{bbl}$ of barite-weighted mud (10.5 ppg), and the pipe was pulled up to 103.8 $\mathrm{m}$ DSF. Three tool strings were deployed in Hole U1387C: the triple combo, VSI, and FMS-sonic tool strings (Fig. F40; see also "Downhole measurements" and Table T6 in the "Methods" chapter [Expedition 339 Scientists, 2013b] for tool definitions).

At $0230 \mathrm{~h}$ UTC on 17 December 2011, the triple combo tool string (resistivity, density, porosity, and natural gamma radiation tools) descended from the rig floor into the pipe (Fig. F41). A downlog was taken at $\sim 900 \mathrm{~m} / \mathrm{h}$ to $\sim 649 \mathrm{mbsf}$, where it was blocked from further downhole progress by a bridge 
in the hole. During the wiper trip, a tight spot from 649 to 653 mbsf had already been noted and worked during hole preparation. The hole was logged up to seafloor at $275 \mathrm{~m} / \mathrm{h}$.

The VSI tool string was run next, because running it after the FMS-sonic tool string would not have left enough daylight hours to complete the VSP. Marine mammal watch started at $0930 \mathrm{~h}$. The soft-start of the Sercel G. Gun parallel cluster (two 250 in $^{3}$ air guns separated by $1 \mathrm{~m}$ ) begun at $1100 \mathrm{~h}$. The air gun cluster was positioned on the port side of the $\mathrm{R} / \mathrm{V}$ JOIDES Resolution at a water depth of $\sim 7 \mathrm{mbsl}$ with a borehole offset of $\sim 45 \mathrm{~m}$. Before reaching the bottom of the hole, a short uplog was taken to ensure depth accuracy by comparing the shape of the VSI gamma ray curve to those of the other logging runs. The VSI tool string reached a blocked zone at 255 mbsf. The shallow penetration for this tool run indicated that the hole was closing quickly with time. Obtaining a good clamp was often difficult with the VSI caliper arm because of the large borehole diameter and soft formation. Consequently, the received sonic waveforms were noisy. Station depths were chosen where the borehole was smooth and in gauge based on the examination of the triple combo resistivity and caliper curves. Five of the seven stations yielded satisfactory first arrival times.

The FMS-sonic tool string was rigged up at $\sim 1540 \mathrm{~h}$ on 17 December. A downlog was taken at $1100 \mathrm{~m} / \mathrm{h}$. Standard (high)-frequency Dipole Sonic Imager transmitter settings were used, with $P$-wave window settings of 130-190 $\mu \mathrm{s} / \mathrm{ft}$. The tool string was blocked from further downhole progress by a bridge at 334 mbsf. The first uphole pass of the FMS-sonic tool string (Pass 1) was run to the seafloor at $550 \mathrm{~m} / \mathrm{h}$. A second uphole pass was run from 278 mbsf to the base of the pipe. Rig down was completed at $2300 \mathrm{~h}$.

The seafloor depth was given by the step in the gamma ray logs. The triple combo downlog found seafloor at $568.5 \mathrm{mbrf}$, and the uplog (main) pass found the seafloor at 568 mbsf. The FMS-sonic Pass 1 found seafloor at 569 mbrf, compared to the drillers mudline tagged at 569.8 mbrf (Hole U1387C). Tides account for only part of this difference; sea level was at $+0.9 \mathrm{~m}$ for the triple combo main pass, $+0.6 \mathrm{~m}$ for FMS Pass 1 , and $+0.3 \mathrm{~m}$ for the drillers mudline in Hole U1386A (see Fig. F48 in the "Site U1386" chapter [Expedition 339 Scientists, 2013d]). Seas were calm, with a maximum peak-to-peak heave of $\sim 0.6$ $\mathrm{m}$, giving little contribution to the offset. Further difference comes from the wireline heave compensator being centered slightly differently for each seafloor depth determination.

\section{Log data quality}

Log data quality was reduced by the range in diameter of the borehole, which often exceeded the 18 inch limit of the Hostile Environment Litho-Density Sonde caliper arm (Fig. F42). Numerous thin, narrow sections with diameters less than the bit size $(9.875$ inches) were also found below 320 mbsf. The VSI and FMS-sonic tool strings were blocked by two of the narrow sections found during the triple combo run at 256 and 335 mbsf. The NGR log strongly anticorrelates with the caliper log. In large part, this is because less gamma radiation reaches the detector in a wider borehole and more reaches the detector when the borehole is closed in. Additionally, the anticorrelation is partly lithologically controlled; sediments lacking clays are more easily washed out. We also analyzed the NGR logs after correction for borehole diameter (by the Schlumberger engineer). This results in smaller amplitude for the peaks associated with narrow parts of the hole and higher values for the wider parts of the hole. However, even small discrepancies in depth between the caliper and NGR logs introduces new errors into the corrected NGR logs, so here we choose to present the original (uncorrected) NGR logs, noting that features associated with very wide or very narrow borehole diameters should be treated with caution because they are likely to have a lesser amplitude on correction.

Of all the logs, resistivity and sonic velocity are the most robust to variable hole diameter. Density and porosity are highly affected, in washouts giving density values close to water (Fig. F42) and porosity close to $100 \%$. The photoelectric effect log shows anomalously high values, especially below $\sim 580$ mbsf, because barium in the logging mud swamped the signal. However, barite-weighted mud was a necessity to keep the borehole open. The FMS resistivity images are also dominated by poor contact with the borehole wall in the wide areas, although some intervals of good images are present.

\section{Logging units}

The Hole U1387C logs change gradually downhole, with no major steps in the base levels. The entire logged interval was thus assigned to one logging unit (Fig. F42). At the scale of this unit, the NGR signal generally ranges from 30 to 60 gAPI, with peak values reaching 85 gAPI. The signal shows moderately high amplitude variability on a several-meter to submeter scale, and given the sedimentological context (see "Lithostratigraphy"), is primarily tracking clay content (quartz and calcite contain no radioactive elements). The signal is dominated by the radioactivity of potassium and thorium, and both curves are generally closely correlated (Fig. F43). Uranium gen- 
erally contributes a moderate component, except in intervals with concentrations $>2.5 \mathrm{ppm}$, in which it can account for as much as $35 \%$ of the total NGR signal. Uranium generally behaves as an independent constituent compared to potassium and thorium because it is not chemically combined in the main rock-forming minerals. The sonic velocity log increases downhole (Fig. F42), reflecting sediment compaction with depth. It generally co-varies with the NGR log.

Logging Unit 1 is divided into four subunits on the basis of changes in mineralogy inferred from the NGR logs and changes in character of the resistivity and sonic logs.

\section{Logging Subunit 1A: base of drill pipe to 211 mbsf}

The upper logging subunit is characterized by medium-amplitude cyclic swings in NGR (including uranium, thorium, and potassium components) and sonic velocity values (Fig. F42). This cyclic pattern resembles the one observed in logging Subunit 1A at Site U1386 (see Fig. F49 in the "Site U1386" chapter [Expedition 339 Scientists, 2013d]). Several orders of cycles are observed, varying from few meters to several tens of meters in thickness (Fig. F44). The potassium and thorium concentrations co-vary closely, suggesting that clay content controls these logs. Although in this subunit there is a separation between the potassium and thorium curves similar to the character of logging Subunit 1B in Hole U1386C, the two intervals are of different ages (see "Biostratigraphy") and therefore do not correlate. The relatively higher potassium levels indicate an increased level of potassium-bearing minerals (e.g., K-feldspar and mica) in addition to clay minerals (Fig. F43). The uranium concentrations are locally relatively well correlated to potassium (e.g., 110-140 and 165-210 mbsf) but vary independently elsewhere in the subunit.

As expected from downhole compaction, the sonic velocity log displays an increasing downhole trend, with slightly lower values from $\sim 140$ to 170 mbsf. The general trend of the resistivity curve correlates well with the sonic velocity, except from $\sim 130$ to 160 mbsf, where resistivity is artificially noisy. The base of logging Subunit $1 \mathrm{~A}$ is close to the base of the physical properties Unit II fixed at 220 mbsf based on the good positive correlation between GRA density, NGR, magnetic susceptibility, and spectral reflectance components $\mathrm{a}^{*}$ and $\mathrm{L}^{*}$ (see "Physical properties"). The transition between logging Subunits 1A and $1 \mathrm{~B}$ does not correlate with any major changes in the sediment record (see "Lithostratigraphy").

\section{Logging Subunit 1B: 211-453 mbsf}

The upper limit of logging Subunit $1 \mathrm{~B}$ is characterized by a step decrease in the sonic, resistivity, and NGR logs (Fig. F42). This subunit is also distinguished from the subunit above by its lower potassium and thorium contents (Fig. F43). Subunit $1 \mathrm{~B}$ is also characterized by less-regular alternations in the NGR logs compared to the subunit above, with some intervals of low-amplitude variability (e.g., 211-234 and 338-362 mbsf) alternating with some intervals containing high amounts of potassium ( $>2 \%)$ forming thin pronounced peaks in the logs (e.g., 255, $322,395$, and $424 \mathrm{mbsf})$. These intervals generally correlate with high resistivity values. The base of Subunit 1B corresponds to the lower limit of lithostratigraphic Unit I at $\sim 454 \mathrm{mbsf}$ in Hole U1387C (see "Lithostratigraphy").

\section{Logging Subunit 1C: 453-510 mbsf}

Logging Subunit 1C is distinguished from the subunit above by the absence of high peaks of potassium and thorium (Fig. F43). Close to the upper limit of this subunit, a probable hiatus spanning from 1.8 to at least 3.19 Ma was detected between Cores 339U1387C-18R and 19R (452.62-458.55 mbsf; see "Biostratigraphy"). On the logs, a double peak of high resistivity values is observed just below, at 461.1 and $462.6 \mathrm{~m}$ wireline depth below seafloor, and the highest uranium content of the entire hole (close to $3 \mathrm{ppm}$ ) is observed between the peaks (Figs. F42, F43). These high-resistivity horizons are caused by two well-consolidated dolostone beds (59 and $12 \mathrm{~cm}$ thick) of fine-grained dolomite that were identified near the top of lithologic Unit II at 457.3-458.0 and 462.7-462.8 mbsf (Cores 339-U1387C-19R and 20R; see "Lithostratigraphy"). The transition between logging Subunits 1C and 1D does not correlate with any major changes in lithology and is located close to the base of physical properties Unit IV, the lower boundary of which was placed at $\sim 500$ mbsf on the basis of the notable increase from decimeter- to meter-scale cycles, high fluctuations in $\mathrm{L}^{*}$, and very low and stable magnetic susceptibility values (see "Physical properties").

\section{Logging Subunit 1D: 510-650 mbsf}

Logging Subunit 1D is distinguished from the subunit above by the presence of $\sim 10$ regularly spaced peaks in potassium and thorium alternating with intervals of lower content at $\sim 12 \mathrm{~m}$ intervals (Fig. F44). The amplitude of the potassium and thorium log variability decreases below 590 mbsf, where good correlation with the uranium log is observed (Fig. F43). The large peaks appear at bridged sections of the hole, so their amplitude will be reduced (but not 
erased) when hole-size correction is taken into account (see "Log data quality"). At first view, the cyclic pattern observed on NGR logs in Subunit 1D seems to reflect lithologic cycles observed in this interval. Although some depth adjustments may be locally required, high NGR values appear to correlate relatively well with thick intervals of very dark greenish gray nannofossil mud (see "Lithostratigraphy"), probably because of high clay content in this lithology. For example, in Figure F44 the dark greenish layers observed at $536.5,539$, and 542 mbsf possibly tie with logged gamma peaks centered at 535 , 539 , and 542 mbsf, whereas the dark layer at 526 mbsf could correlate with the peak at 525 mbsf. These distinctive peaks can also be correlated to the NGR data measured on cores.

\section{Formation MicroScanner resistivity images}

Despite the rugosity of the borehole wall associated with the presence of washout intervals, FMS resistivity images reveal locally some gradual and sharp transitions between alternations of resistive and conductive beds thicker than $\sim 5 \mathrm{~cm}$. Some of these alternations correlate well with the resistivity curves from the triple combination tool string (Fig. F45). Where silty sand and silty mud layers correlate with lower values in the NGR log (i.e, approximately 216-218, 221-223, and 232-234 mbsf in Fig. F45), the FMS resistivity images illustrate locally small-scale changes in the sediment electrical properties that may be related to subtle changes in clay content or sediment hardness. The FMS resistivity images, however, remain dominated by poor contact with the borehole wall in the wide areas. FMS caliper logs also show that new tight points developed since the triple combination tool string was run, indicating that the hole was closing quickly with time.

\section{Vertical seismic profile and sonic velocity}

One objective of the expedition is to establish the age and lithologic origin of the seismic reflections previously identified in seismic sections. Three ways of correlating between stratigraphy and seismic sections are by

1. VSP check shot traveltime,

2. Traveltime derived from the sonic velocity $\log$, and

3. Synthetic seismogram.

In the VSP, five of the seven stations yielded check shots ranging from $0.8934 \mathrm{~s}$ two-way traveltime (TWT) at 131.0 mbsf to $1.0274 \mathrm{~s}$ TWT at the deepest station at 252.1 mbsf (Fig. F46; Table T20). Many of the seismic waveforms were noisy, and it was difficult to clamp the tool's caliper arm firmly in the of- ten wide borehole, but the waveform stacks from the five successful stations appear to be good. Sonic velocities increase downhole with a linear trend of $\sim 0.1$ $\mathrm{km} / \mathrm{s}$ per $100 \mathrm{~m}$ between 104 and $318 \mathrm{mbsf}$. The similarity of the resistivity logs to the sonic velocity log (Fig. F42) offers the potential for a "pseudosonic" log to be constructed from the resistivity data to 650 mbsf and used as input for a synthetic seismogram.

\section{Heat flow}

One APCT-3 downhole temperature measurement was made at this site, on Core 339-U1387B-4H. The temperature was $14.65^{\circ} \mathrm{C}$. The shallow change to $\mathrm{XCB}$ drilling at $\sim 47$ mbsf prevented more measurements from being obtained. Geothermal gradient and heat flow could not be determined from this one measurement, but it is similar to (slightly higher than) the temperature and an equivalent depth at Site U1386 (see "Downhole measurements" in the "Site U1386" chapter [Expedition 339 Scientists, 2013d]).

\section{Stratigraphic correlation}

The meters composite depth (mcd) scale at Site U1387 was based primarily on correlation of magnetic susceptibility between holes in the upper 153 mcd and on a combination of NGR and magnetic susceptibility data below 153 mcd. GRA density data provided confirmation of the correlation in some intervals and was used as a constraint in other intervals where susceptibility and NGR were low or lacked correlative features.

The correlation between Holes U1387A and U1387B is relatively straightforward downhole to $153 \mathrm{mcd}$, with a few exceptions (Figs. F47, F48). Two of these exceptions are the short Cores 339-U1387A-6H and 339-U1387B-9X, neither of which have susceptibility, NGR, or density anomalies that correlate particularly well with the other hole. Also, the continuity of correlation from one core to the next is problematic because the gaps between Cores 339-U1387A-7X and $16 \mathrm{X}$ are aligned with those between Cores 339U1387B-6X and 15X, respectively. This unfortunate coincidence resulted even though Hole U1387B was initially spudded $4 \mathrm{~m}$ deeper than Hole U1387A, which was sufficient enough offset gaps in Hole U1387A that were filled by cores from Hole U1387B and vice versa. This situation changed below $\sim 55$ mcd. Drilling difficulties in Hole U1387A led to coring several short intervals rather than the typical 9.6 $\mathrm{m}$ core. These changes in the drilling offset between holes in combination with tidal variations resulted in the cored intervals in Holes U1387A and U1387B virtually aligning from $\sim 55$ to $140 \mathrm{mcd}$. Once physi- 
cal property data had been acquired from the STMSL, short Core 339-U1387B-16X was drilled to rectify this situation. Given the calm sea conditions and relatively shallow water depth, the amount of material lost between cores is relatively small (roughly a few tens of centimeters), as can be noted in the correlation and splice (Figs. F47, F48).

Gaps are very short or nonexistent in the composite stratigraphic record from $\sim 155$ to $395 \mathrm{mcd}$, which spans from the top of Core 339-U1387B-16X downhole to the base of Core 339-U1387C-8R. Below this, the section is only single-cored, so some material is lost between each core.

Although the exact amount of material missing cannot be precisely determined for those cores where the gaps align between holes or for the gaps between cores in single-cored intervals, estimates can be made in two ways. First, prior construction of mcd scales have shown repeatedly that expansion between mcd and mbsf scales is $7 \%-15 \%$. Hence, a similar expansion should be expected. In fact, we observed that a moderately accurate mcd scale could be constructed by merely expanding the mbsf depth scale by $\sim 10 \%$. Ultimately, detailed correlation is necessary, but, where correlative features do not exist, using a $\sim 10 \%$ expansion factor serves as a useful guide and provides rough estimates for the amount of material that might have been missed in the coring gaps. Also, the Site U1387 susceptibility, density, and NGR records correlate well with the Site U1386 splice, particularly in the upper 150 mbsf. Furthermore, logging NGR data (standard [total] gamma ray [HSGR]) in Hole U1387C correlates well with NGR data from the cores. Correlation with both Site U1386 and with the Site U1387 HSGR data allows us to examine the relative amount of material missing within the coring gaps and to adjust the mcd scale by an appropriate amount. Below 150 mbsf, the Site U1386 splice is less certain (see "Stratigraphic correlation" in the "Site U1386" chapter [Expedition 339 Scientists, 2013d]), and we do not use it as a guide, although the Site U1387 HSGR data retain good correlation over the entire interval that was multicored.

Correlation between some cores is obvious, but expansion of one core relative to another requires that aligning one anomaly can misalign other anomalies. This is particularly evident for the correlation of Core 339-U1387A-13X with 339-U1387B-12X. The interval recovered in these two cores overlaps nearly completely, but Core 339-U1387B-12X is expanded by $\sim 12 \%$ relative to Core $339-\mathrm{U} 1387 \mathrm{~A}-13 \mathrm{X}$. Below Core 339-U1387B-16X, gaps between cores in one hole are mostly filled by cores from other holes. Even so, several of the links between cores are uncer- tain because the susceptibility signal is relatively weak and coring disturbance (biscuiting) is pervasive. This weak susceptibility signal appears to be anomalous in several cores, possibly from minor drilling-related contamination. This appears to be the case for the base of several cores, from Core 339U1387A-20X to the base of 25X. Hence, we rely heavily on NGR data to link the top of Core 339U1387A-21X to the base of 339-U1387B-20X and a turbidite (occurring in intervals 339-U1387A-24X-7, 43-70 cm, and 339-U1387B-24X-4, 48-75 cm; see "Lithostratigraphy") to link Core 339-U1387A-24X to 339-U1387B-24X. Links that rely heavily on NGR data are generally not as well constrained as when susceptibility anomalies are used because NGR data are collected at lower resolution and NGR anomalies have a relatively long wavelength (3-15 m). NGR data do, however, have roughly cyclic alternations that can be correlated between holes as well as to HSGR data. HSGR data were thus used to aid in correlating some of the more complicated intervals, such as that between 300 and 340 mcd.

The offsets and composite depths are listed in Table T21. A growth factor of 1.105 is calculated by linear regression for the multicored interval at Site U1387, indicating a $10.5 \%$ increase in mcd values relative to mbsf values (Fig. F49). Because of the very linear nature of the expansion, the mcd scale can readily be compressed by dividing by 1.105 to produce a modified mcd that corresponds more closely to true coring depths while retaining the between-hole correlations.

The three holes cored at Site U1387 provide enough material to produce a splice with relatively few gaps within the upper 395 mcd of the section, except in those intervals where coring gaps in Holes U1387A and U1387B aligned, as noted above (Figs. F47, F48; Table T22). Below this, most of the section is singlecored, and the spliced section is created by merely appending the remaining cores using a $10.4 \%$ expansion, which corresponds to adding a $1 \mathrm{~m}$ gap between each $9.6 \mathrm{~m}$ core. Spliced records are provided for susceptibility (Table T23) and NGR (Table T24), which were first cleaned by removing data affected by section- and core-edge artifacts or that occurred in disturbed intervals or gaps, as listed in Table T13.

\section{References}

Alvarez Zarikian, C.A., Stepanova, A.Y., and Grützner, J., 2009. Glacial-interglacial variability in deep sea ostracod assemblage composition at IODP Site U1314 in the subpolar North Atlantic. Mar. Geol., 258(1-4):69-87. doi:10.1016/j.margeo.2008.11.009 
Alves, T.M., Gawthorpe, R.L., Hunt, D.W., and Monteiro, J.H., 2003. Cenozoic tectono-sedimentary evolution of the western Iberian margin. Mar. Geol., 195(1-4):75108. doi:10.1016/S0025-3227(02)00683-7

Bayliss, D.D., 1969. The distribution of Hyalinea balthica and Globorotalia truncatulinoides in the type Calabrian. Lethaia, 2(2):133-143. doi:10.1111/j.15023931.1969.tb01632.x

Berggren, W.A., and Hollister, C.D., 1974. Paleogeography, paleobiogeography and the history of circulation of the Atlantic Ocean. In Hay, W.W. (Ed.), Studies in Paleooceanography. Spec. Publ.-Soc. Econ. Paleontol. Mineral., 20:126-186. doi:10.2110/pec.74.20.0126

Blanc, P.-L., 2002. The opening of the Plio-Quaternary Gibraltar Strait: assessing the size of a cataclysm. Geodin. Acta, 15(5-6):303-317. doi:10.1016/S09853111(02)01095-1

Blum, P., 1997. Physical properties handbook: a guide to the shipboard measurement of physical properties of deep-sea cores. ODP Tech. Note, 26. doi:10.2973/ odp.tn.26.1997

Bonaduce, G., Ciampo, G., and Masoli, M., 1975. Distribution of Ostracoda in the Adriatic Sea. Pubbl. Stn. Zool. Napoli, 40:1-304.

Briand, F. (Ed.), 2008. The Messinian Salinity Crisis from megadeposits to microbiology - a consensus report. CIESM Workshop Monogr., 33:45-48. http:// www.ciesm.org/online/monographs/Almeria07.pdf

Cronin, T.M., 1983. Bathyal ostracodes from the FloridaHatteras slope, the straits of Florida, and the Blake Plateau. Mar. Micropaleontol., 8(2):89-119. doi:10.1016/ 0377-8398(83)90007-5

Didié, C., and Bauch, H.A., 2000. Species composition and glacial-interglacial variations in the ostracode fauna of the northeast Atlantic during the past 200,000 years. Mar. Micropaleontol., 40(1-2):105-129. doi:10.1016/ S0377-8398(00)00034-7

Duggen, S., Hoernle, K., van den Bogaard, P., Rüpke, L., and Morgan, J.P., 2003. Deep roots of the Messinian salinity crisis. Nature (London, U. K.), 422(6932):602606. doi:10.1038/nature01553

Egbert, G.D., and Erofeeva, S.Y., 2002. Efficient inverse modeling of barotropic ocean tides. J. Atmos. Oceanic Technol., 19(2):183-204. doi:10.1175/15200426(2002)019<0183:ЕIMOBO>2.0.CO;2

Emerson, S., and Hedges, J.I., 1988. Processes controlling the organic carbon content of open ocean sediments. Paleoceanography, 3(5):621-634. doi:10.1029/ PA003i005p00621

Estrada, F., Ercilla, G., Gorini, C., Alonso, B., Vázquez, J.T., García-Castellanos, D., Juan, C., Maldonado, A., Ammar, A., and Elabbassi, M., 2011. Impact of pulsed Atlantic water inflow into the Alboran Basin at the time of the Zanclean flooding. Geo-Mar. Lett., 31(5-6):361376. doi:10.1007/s00367-011-0249-8

Expedition 339 Scientists, 2013a. Expedition 339 summary. In Stow, D.A.V., Hernández-Molina, F.J., Alvarez Zarikian, C.A., and the Expedition 339 Scientists, Proc. IODP, 339: Tokyo (Integrated Ocean Drilling Program
Management International, Inc.). doi:10.2204/

iodp.proc.339.101.2013

Expedition 339 Scientists, 2013b. Methods. In Stow, D.A.V., Hernández-Molina, F.J., Alvarez Zarikian, C.A., and the Expedition 339 Scientists, Proc. IODP, 339: Tokyo (Integrated Ocean Drilling Program Management International, Inc.). doi:10.2204/iodp.proc.339.102.2013

Expedition 339 Scientists, 2013c. Site U1385. In Stow, D.A.V., Hernández-Molina, F.J., Alvarez Zarikian, C.A., and the Expedition 339 Scientists, Proc. IODP, 339: Tokyo (Integrated Ocean Drilling Program Management International, Inc.). doi:10.2204/ iodp.proc.339.103.2013

Expedition 339 Scientists, 2013d. Site U1386. In Stow, D.A.V., Hernández-Molina, F.J., Alvarez Zarikian, C.A., and the Expedition 339 Scientists, Proc. IODP, 339: Tokyo (Integrated Ocean Drilling Program Management International, Inc.). doi:10.2204/

iodp.proc.339.104.2013

Faugères, J.-C., Frappa, M., Gonthier, E., and Grousset, F., 1985. Impact de la veine deau méditerranéenne sur la sedimentation de la marge sud et ouest Iberique au Quaterbaire recent. Bull. Inst. Geol. Bassin Aquitaine, 37:259287.

Fernández-Puga, M.C., Vázquez, J.T., Somoza, L., Díaz del Rio, V., Medialdea, T., Mata, M.P., and León, R., 2007. Gas-related morphologies and diapirism in the Gulf of Cádiz. Geo-Mar. Lett., 27(2-4):213-221. doi:10.1007/ s00367-007-0076-0

Flores, J.-A., Colmenero-Hidalgo, E., Mejía-Molina, A.E., Baumann, K.-H., Hendericks, J., Larsson, K., Prabhu, C.N., Sierro, F.J., and Rodrigues, T., 2010. Distribution of large Emiliania huxleyi in the central and northeast Atlantic as a tracer of surface ocean dynamics during the last 25,000 years. Mar. Micropaleontol., 76(3-4):5366. doi:10.1016/j.marmicro.2010.05.001

Flores, J.A., and Sierro, F.J., 1989. Calcareous nannoflora and planktonic foraminifera in the Tortonian-Messinian boundary interval of East Atlantic DSDP sites and their relation to Spanish and Moroccan sections. In Crux, J.A., and van Heck, S.E. (Eds.), Nannofossils and Their Applications: Chichester (Ellis Horwood), 249-266.

García, M., Hernández-Molina, F.J., Llave, E., Stow, D.A.V., León, R., Fernández-Puga, M.C., Díaz del Río, V., and Somoza, L., 2009. Contourite erosive features caused by the Mediterranean Outflow Water in the Gulf of Cádiz: Quaternary tectonic and oceanographic implications. Mar. Geol., 257(1-4):24-40 doi:10.1016/j.margeo.2008.10.009

Garcia-Castellanos, D., Estrada, F., Jiménez-Munt, I., Gorini, C., Fernàndez, M., Vergés, J., and De Vicente, R., 2009. Catastrophic flood of the Mediterranean after the Messinian salinity crisis. Nature (London, U. K.), 462(7274):778-781. doi:10.1038/nature08555

Garcia-Castellanos, D., and Villaseñor, A., 2011. Messinian salinity crisis regulated by competing tectonics and erosion at the Gibraltar arc. Nature (London, U. K.), 480(7377):359-363. doi:10.1038/nature10651

Gonthier, E.G., Faugeres, J.C., and Stow, D.A.V., 1984. Contourite facies of the Faro Drift, Gulf of Cádiz. In Stow, 
D.A.V., and Piper, D.J.W. (Eds.), Fine-Grained Sediments: Deep Water Processes and Facies. Geol. Soc. Spec. Publ., 15:275-292. doi:10.1144/GSL.SP.1984.015.01.18

Hanquiez, V., Mulder, T., Lecroart, P., Gonthier, E., Marchès, E., and Voisset, M., 2007. High resolution seafloor images in the Gulf of Cádiz, Iberian margin. Mar. Geol., 246(1):42-59. doi:10.1016/j.margeo.2007.08.002

Hayward, B.W., 2002. Late Pliocene to middle Pleistocene extinctions of deep-sea benthic foraminifera ("Stilostomella extinction") in the southwest Pacific. J. Foraminiferal Res., 32(3):274-307. doi:10.2113/32.3.274

Hernández-Molina, F.J., Llave, E., Stow, D.A.V., García, M., Somoza, L., Vázquez, J.T., Lobo, F.J., Maestro, A., Díaz del Río, V., León, R., Medialdea, T., and Gardner, J., 2006. The contourite depositional system of the Gulf of Cádiz: a sedimentary model related to the bottom current activity of the Mediterranean Outflow Water and its interaction with the continental margin. Deep-Sea Res., Part II, 53(11-13):1420-1463. doi:10.1016/ j.dsr2.2006.04.016

Hernández-Molina, F.J., Matias, H., Llave, E., and Stow, D.A.V., 2009. Onset of contourite deposition in the Gulf of Cádiz: preliminary results [6th Symposium on the Iberian Atlantic Margin (MIA 09), 1-5 December 2009, Oviedo, Spain].

Hilgen, F.J., 1991. Extension of the astronomically calibrated (polarity) time scale to the Miocene/Pliocene boundary. Earth Planet. Sci. Lett., 107(2):349-368. doi:10.1016/0012-821X(91)90082-S

Jiménez-Moreno, G., Fauquette, S., and Suc, J.-P., 2010. Miocene to Pliocene vegetation reconstruction and climate estimates in the Iberian Peninsula from pollen data. Rev. Palaeobot. Palynol., 162(3):403-415. doi:10.1016/j.revpalbo.2009.08.001

Kawagata, S., Hayward, B.W., Grenfell, H.R., and Sabaa, A., 2005. Mid-Pleistocene extinction of deep-sea foraminifera in the North Atlantic Gateway (ODP Sites 980 and 982). Palaeogeogr., Palaeoclimatol., Palaeoecol., 221(34):267-291. doi:10.1016/j.palaeo.2005.03.001

Khélifi, N., Sarnthein, M., Andersen, N., Blanz, T., Frank, M., Garbe-Schönberg, D., Haley, B.A., Stumpf, R., and Weinelt, M., 2009. A major and long-term Pliocene intensification of the Mediterranean outflow, 3.5-3.3 Ma ago. Geology, 37(9):811-814. doi:10.1130/ G30058A.1

Kirschvink, J.L., 1980. The least-squares line and plane and the analysis of palaeomagnetic data. Geophys. J. $R$. Astron. Soc., 62(3):699-718. doi:10.1111/j.1365246X.1980.tb02601.x

Leckie, R.M., and Olson, H.C., 2003. Foraminifera as proxies of sea-level change on siliciclastic margins. In Olson, H.C., and Leckie, R.M. (Eds.), Micropaleontologic Proxies of Sea-Level Change and Stratigraphic Discontinuities. Spec. Publ.-SEPM (Soc. Sediment. Geol.), 75:5-19.

Llave, E., Hernández-Molina, F.J., Somoza, L., Díaz del Río, V., Stow, D.A.V., Maestro, A., and Alveirinho Dias, J.M., 2001. Seismic stacking pattern of the Faro-Albufeira contourite system (Gulf of Cádiz): a Quaternary record of paleoceanographic and tectonic influences. Mar. Geo- phys. Res., 22(5-6):487-508. doi:10.1023/

A:1016355801344

Llave, E., Hernández-Molina, F.J., Somoza, L., Stow, D.A.V., and Díaz Del Río, V., 2007a. Quaternary evolution of the contourite depositional system in the Gulf of Cádiz. Geol. Soc. Spec. Publ., 276:49-79. doi:10.1144/

GSL.SP.2007.276.01.03

Llave, E., Hernández-Molina, F.J., Stow, D.A.V., FernándezPuga, M.C., García, M., Vázquez, J.T., Maestro, A., Somoza, L., and Díaz del Río, V., 2007b. Reconstructions of the Mediterranean Outflow Water during the Quaternary based on the study of changes in buried mounded drift stacking pattern in the Gulf of Cádiz. Mar. Geophys. Res., 28(4):379-394. doi:10.1007/s11001-007-9040-7

Llave, E., Matias, H., Hernández-Molina, F.J., Ercilla, G., Stow, D.A.V., and Medialdea, T., 2011. Pliocene-Quaternary contourites along the northern Gulf of Cadiz margin: sedimentary stacking pattern and regional distribution. Geo-Mar. Lett., 31(5-6):377-390. doi:10.1007/s00367-011-0241-3

Lourens, L., Hilgen, F., Shackleton, N.J., Laskar, J., and Wilson, D., 2004. The Neogene period. In Gradstein, F.M., Ogg, J.G., and Smith, A. (Eds.), A Geologic Time Scale 2004: Cambridge (Cambridge Univ. Press), 409-440.

Maldonado, A., Somoza, L., and Pallarés, L., 1999. The Betic orogen and the Iberian-African boundary in the Gulf of Cádiz: geological evolution (central North Atlantic). Mar. Geol., 155(1-2):9-43. doi:10.1016/ S0025-3227(98)00139-X

Marchès, E., Mulder, T., Cremer, M., Bonnel, C., Hanquiez, V., Gonthier, E., and Lecroart, P., 2007. Contourite drift construction influenced by capture of Mediterranean Outflow Water deep-sea current by the Portimão submarine canyon (Gulf of Cádiz, south Portugal). Mar. Geol., 242(4):247-260. doi:10.1016/j.margeo.2007.03.013

Marchès, E., Mulder, T., Gonthier, E., Cremer, M., Hanquiez, V., Garlan, T., and Lecroart, P., 2010. Perched lobe formation in the Gulf of Cádiz: interactions between gravity processes and contour currents (Algarve margin, southern Portugal). Sediment. Geol., 229(3):81-94. doi:10.1016/j.sedgeo.2009.03.008

Medialdea, T., Somoza, L., Pinheiro, L.M., Fernández-Puga, M.C., Vázquez, J.T., León, R., Ivanov, M.K., Magalhaes, V., Díaz del Río, V., and Vegas, R., 2009. Tectonics and mud volcano development in the Gulf of Cádiz. Mar. Geol., 261(1-4):48-63. doi:10.1016/j.margeo.2008.10.007

Medialdea, T., Vegas, R., Somoza, L., Vázquez, J.T., Maldonado, A., Díaz-del-Río, V., Maestro, A., Córdoba, D., and Fernández-Puga, M.C., 2004. Structure and evolution of the "Olistostrome" complex of the Gibraltar arc in the Gulf of Cádiz (eastern Central Atlantic): evidence from two long seismic cross-sections. Mar. Geol., 209(14):173-198. doi:10.1016/j.margeo.2004.05.029

Meister, P., Bernasconi, S.M., Vasconcelos, C., and McKenzie, J.A., 2008. Sea level changes control diagenetic dolomite formation in hemipelagic sediments of the Peru margin. Mar. Geol., 252(3-4):166-173. doi:10.1016/j.margeo.2008.04.001 
Meyers, P.A., 1997. Organic geochemical proxies of paleoceanographic, paleolimnologic, and paleoclimatic processes. Org. Geochem., 27(5-6):213-250. doi:10.1016/ S0146-6380(97)00049-1

Moore, T.S., Murray, R.W., Kurtz, A.C., and Schrag, D.P., 2004. Anaerobic methane oxidation and the formation of dolomite. Earth Planet. Sci. Lett., 229(1-2):141-154. doi:10.1016/j.epsl.2004.10.015

Mougenot, D., 1988. Géologie de la Marge Portugaise [thése de Doctorat d'Etat des Sciences Naturelles]. Univ. Pierre et Marie Curie, Paris.

Mulder, C.J., and Parry, G.R., 1977. Late Tertiary evolution of the Alboran Sea at the eastern entrance of the Strait of Gibraltar. In Biju-Duval, B., and Montadert, L. (Eds.), Structural History of the Mediterranean Basins: Paris (Ed. Technip), 401-410.

Murray, J.W., 2006. Ecology and Applications of Benthic Foraminifera: Cambridge (Cambridge Univ. Press).

Nelson, C.H., Baraza, J., Maldonado, A., Rodero, J., Escutia, C., and Barber, J.H., Jr., 1999. Influence of the Atlantic inflow and Mediterranean outflow currents on late Quaternary sedimentary facies of Gulf of Cádiz continental margin. Mar. Geol., 155(1-2):99-129. doi:10.1016/S0025-3227(98)00143-1

Maldonado, A., and Nelson, C.H., 1999. Interaction of tectonic and depositional processes that control the evolution of the Iberian Gulf of Cádiz margin. Mar. Geol., 155(1-2):217-242. doi:10.1016/S0025-3227(98)00148-0

Raffi, I., Backman, J., Fornaciari, E., Pälike, H., Rio, D., Lourens, L., and Hilgen, F., 2006. A review of calcareous nannofossil astrobiochronology encompassing the past 25 million years. Quat. Sci. Rev., 25(23-24):3113-3137. doi:10.1016/j.quascirev.2006.07.007

Raffi, I., Backman, J., Rio, D., and Shackleton, N.J., 1993. Plio-Pleistocene nannofossil biostratigraphy and calibration to oxygen isotope stratigraphies from Deep Sea Drilling Project Site 607 and Ocean Drilling Program Site 677. Paleoceanography, 8(3):387-408. doi:10.1029/ 93PA00755

Riaza, C., and Martinez del Olmo, W., 1996. Depositional model of the Guadalquivir-Gulf of Cádiz Tertiary basin. In Friend, P.F., and Dabrio, C.J. (Eds.), Tertiary Basins of Spain: The Stratigraphic Record of Crustal Kinematics: Cambridge (Cambridge Univ. Press), 330-338. doi:10.1017/CBO9780511524851.047

Roque, C., Duarte, H., Terrinha, P., Valadares, V., Noiva, J., Cachão, M., Ferreira, J., Legoinha, P., and Zitellini, N., 2012. Pliocene and Quaternary depositional model of the Algarve margin contourite drifts (Gulf of Cádiz, SW Iberia): seismic architecture, tectonic control, and paleoceanographic insights. Mar. Geol., 303-306:42-62. doi:10.1016/j.margeo.2011.11.001

Ruiz, F., and Gonzalez-Regalado, M.L., 1996. Les ostracodes du golfe Mio-Pliocene du sud-ouest de L'Espagne. Rev. Micropaléontol., 39(2):137-151. doi:10.1016/S00351598(96)90038-0

Ruiz, F., González-Regalado, M.L., Abad, M., Civis, J., González Delgado, J.A., Mara García, E.X., Prudêncio, M.I., and Dias, M.I., 2008. Pliocene ostracods of southwest- ern Europe. Geobios, 41(6):845-859. doi:10.1016/j.geobios.2007.07.004

Ruttenberg, K.C., and Goñi, M.A., 1997. Phosphorus distribution, $\mathrm{C}: \mathrm{N}: \mathrm{P}$ ratios, and $\delta^{13} \mathrm{C}_{\mathrm{oc}}$ in arctic, temperate, and tropical coastal sediments: tools for characterizing bulk sedimentary organic matter. Mar. Geol., 139(1-4):123145. doi:10.1016/S0025-3227(96)00107-7

Ryan, W.B.F., Hsü, K.J., Cita, M.B., Dumitrica, P., Lort, J., Maync, W., Nesteroff, W.D., Pautot, G., Stradner, H., and Wezel, F.C., 1973. Western Alboran Basin-Site 121. In Ryan, W.B.F., Hsü, K.J., et al., Init. Repts. DSDP, 13: Washington, DC (U.S. Govt. Printing Office), 43-89. doi:10.2973/dsdp.proc.13.103.1973

Sánchez Goñi, M.F., 1994. The identification of European upper palaeolithic interstadials from cave sequences. In Davis, O.K. (Ed.), Aspects of Archaeological Palynology: Methodology and Applications. AASP Contrib. Ser., 29:161-182.

Schönfeld, J., 1997. The impact of the Mediterranean Outflow Water (MOW) on benthic foraminiferal assemblages and surface sediments at the southern Portuguese continental margin. Mar. Micropaleontol., 29(3-4):211236. doi:10.1016/S0377-8398(96)00050-3

Schönfeld, J., 2002. Recent benthic foraminiferal assemblages in deep high-energy environments from the Gulf of Cádiz (Spain). Mar. Micropaleontol., 44(3-4):141-162. doi:10.1016/S0377-8398(01)00039-1

Schönfeld, J., and Zahn, R., 2000. Late glacial to Holocene history of the Mediterranean Outflow. Evidence from benthic foraminiferal assemblages and stable isotopes at the Portuguese margin. Palaeogeogr., Palaeoclimatol., Palaeoecol., 159(1-2):85-111. doi:10.1016/S00310182(00)00035-3

Somoza, L., Díaz-del-Rio, V., León, R., Ivanov, M., Fernández-Puga, M.C., Gardner, J.M., Hernández-Molina, F.J., Pinheiro, L.M., Rodero, J., Lobato, A., Maestro, A., Vázquez, J.T., Medialdea, T., and Fernández-Salas, L.M., 2003. Seabed morphology and hydrocarbon seepage in the Gulf of Cádiz mud volcano area: acoustic imagery, multibeam and ultra-high resolution seismic data. Mar. Geol., 195(1-4):153-176. doi:10.1016/S00253227(02)00686-2

Stow, D., Hernández-Molina, F.J., Hodell, D., and Alvarez Zarikian, C.A., 2011. Mediterranean outflow: environmental significance of the Mediterranean Outflow Water and its global implications. IODP Sci. Prosp., 339. doi:10.2204/iodp.sp.339.2011

Terrinha, P., Pinheiro, L.M., Henriet, J.-P., Matias, L., Ivanov, M.K., Monteiro, J.H., Akhmetzhanov, A., Volkonskaya, A., Cunha, T., Shaskin, P., and Rovere, M., 2003. Tsunamigenic-seismogenic structures, neotectonics, sedimentary processes, and slope stability on the southwest Portuguese margin. Mar. Geol., 195(1-4):55-73. doi:10.1016/S0025-3227(02)00682-5

van Morkhoven, F.P.C.M., Berggren, W.A., and Edwards, A.S., 1986. Cenozoic Cosmopolitan Deep-Water Benthic Foraminifera. Bull. Cent. Rech. Explor.-Prod. Elf-Aquitaine, 11.

Wei, W., 1993. Calibration of upper Pliocene-lower Pleistocene nannofossil events with oxygen isotope stratigra- 
phy. Paleoceanography, 8(1):85-99. doi:10.1029/ 92PA02504

Xuan, C., and Channell, J.E.T., 2009. UPmag: MATLAB software for viewing and processing $U$ channel or other pass-through paleomagnetic data. Geochem., Geophys., Geosyst., 10(10):Q10Y07. doi:10.1029/2009GC002584

Yassini, I., 1979. The littoral system ostracodes from the Bay of Bou-Ismail, Algiers, Algeria. Rev. Esp. Micropaleontol., 11(3):353-416.

Young, J.R., 1998. Neogene. In Bown, P.R. (Ed.), Calcareous Nannofossil Biostratigraphy: Dordrecht, The Netherlands (Kluwer Academic Publ.), 225-265.
Zitellini, N., Gràcia, E., Matias, L., Terrinha, P., Abreu, M.A., DeAlteriis, G., Henriet, J.P., Dañobeitia, J.J., Masson, D.G., Mulder, T., Ramella, R., Somoza, L., and Diez, S., 2009. The quest for the Africa-Eurasia plate boundary west of the Strait of Gibraltar. Earth Planet. Sci. Lett., 280(1-4):13-50. doi:10.1016/j.epsl.2008.12.005

Publication: 17 June 2013

MS 339-105 
Figure F1. Graphic lithology summary log, Site U1387. "IA", "IB", and "IC" are informal subdivisions within lithologic Unit I, used to simplify correlations to Sites U1386 and U1389. MOW = Mediterranean Outflow Water.

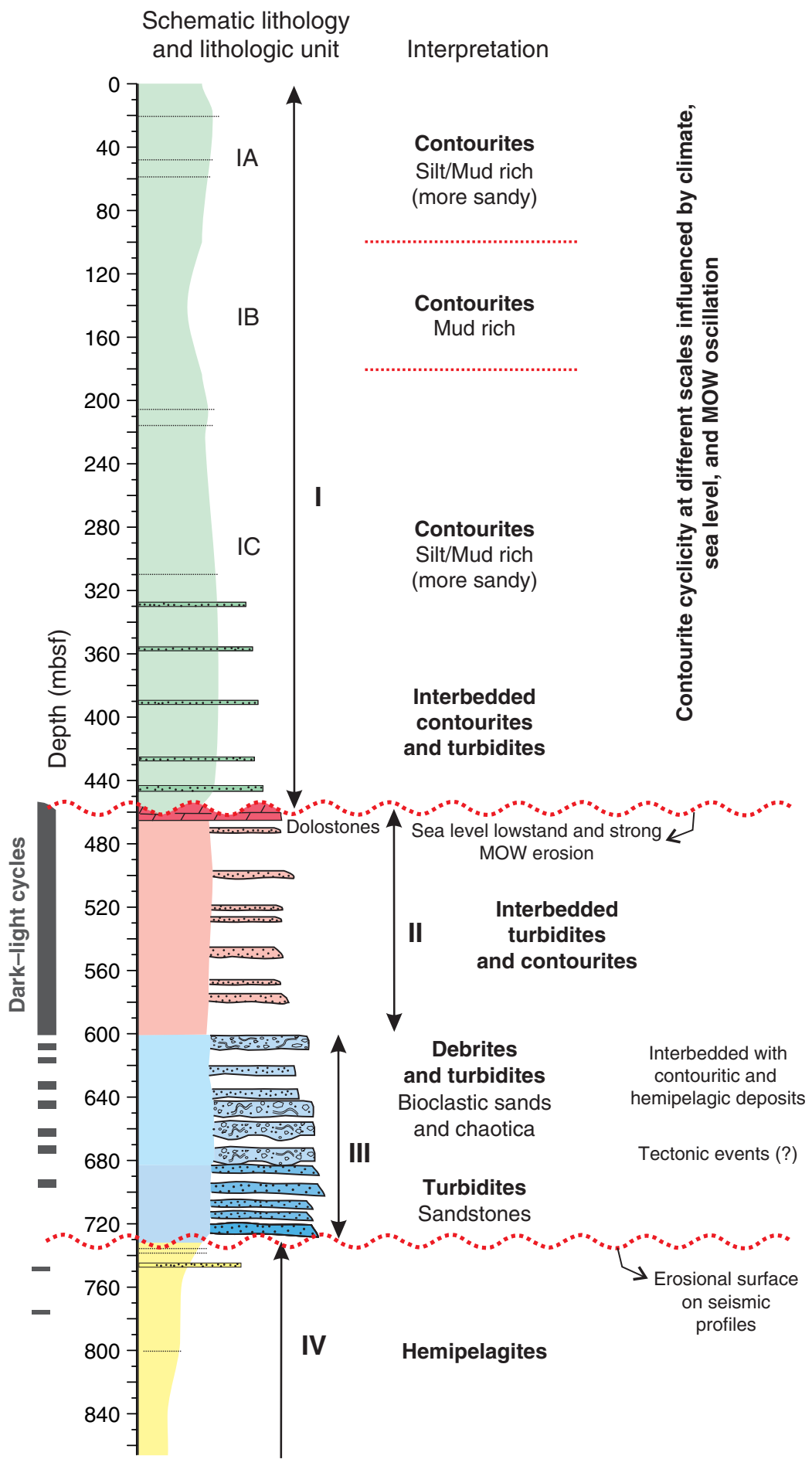


Figure F2. Graphic lithology summaries, Site U1387. A. Hole U1387A. (Continued on next two pages.)

A

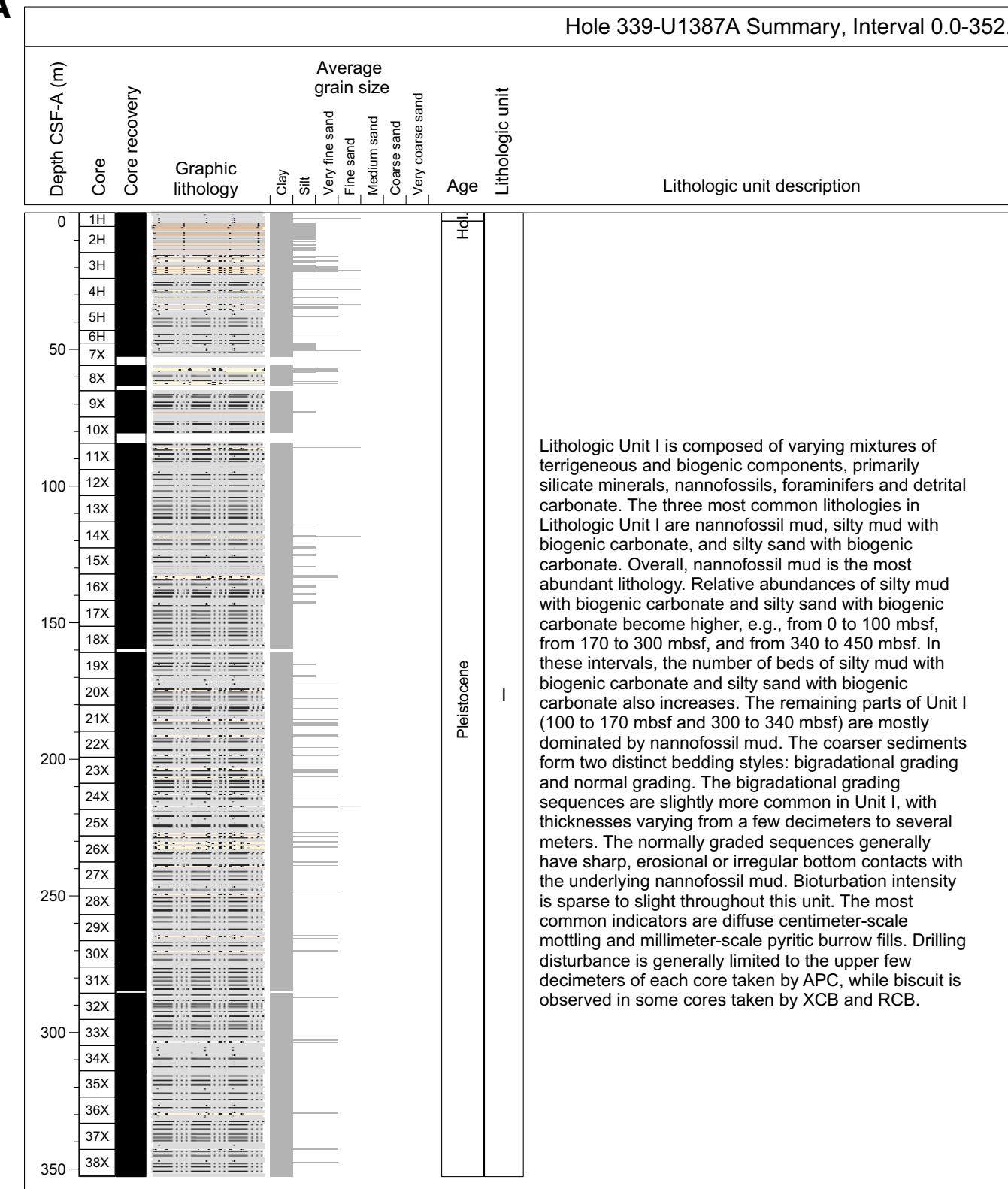

$.75 \mathrm{~m}(\mathrm{CSF}-\mathrm{A})$

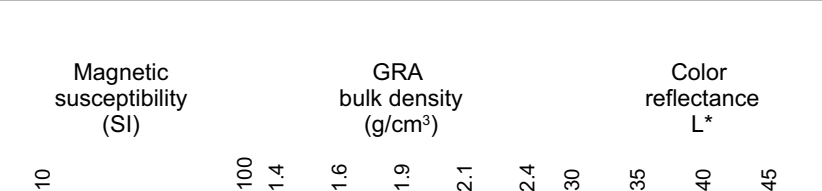
$\stackrel{1}{1}$

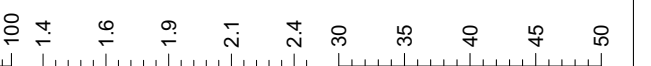

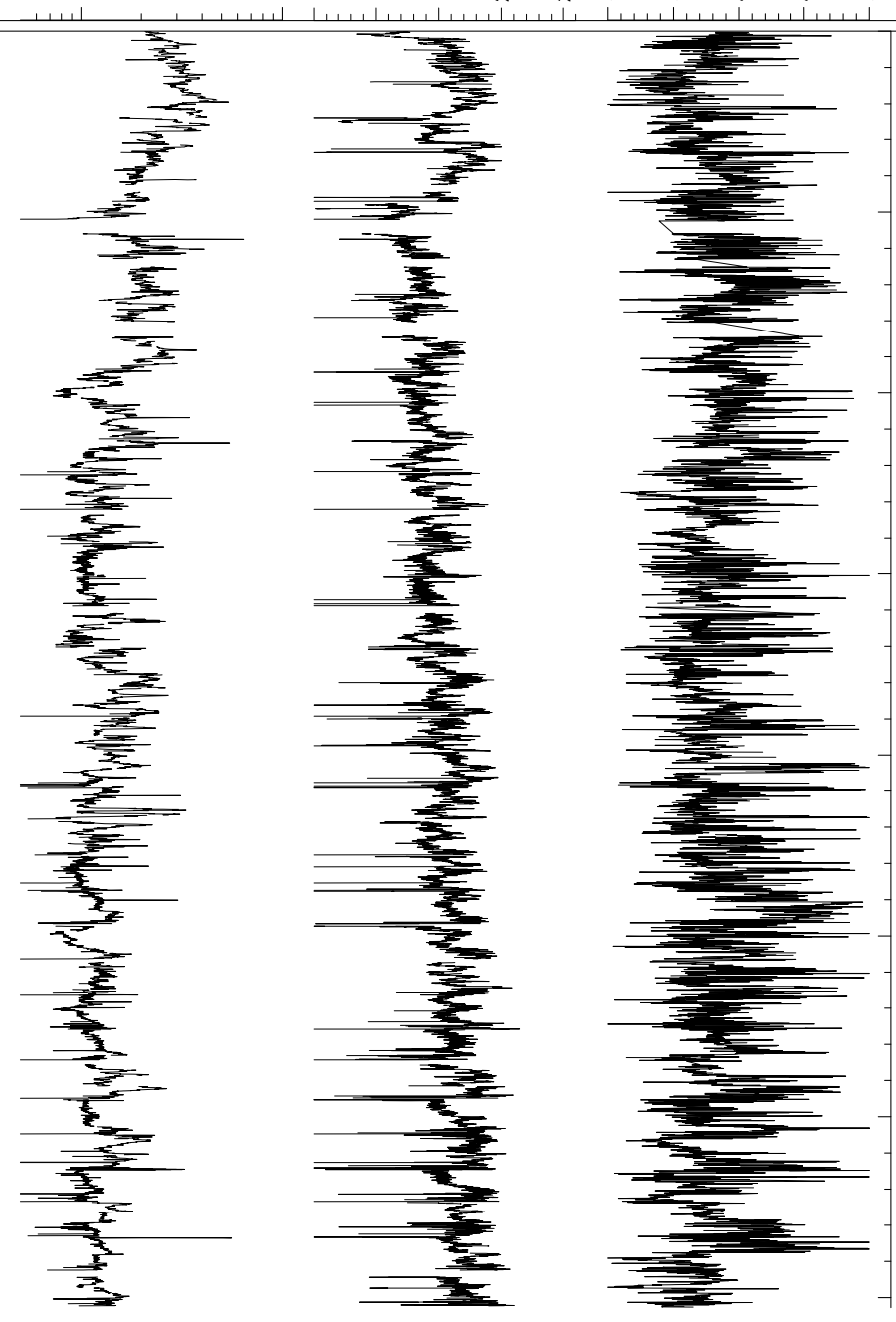


Figure F2 (continued). B. Hole U1387B. (Continued on next page.)

B

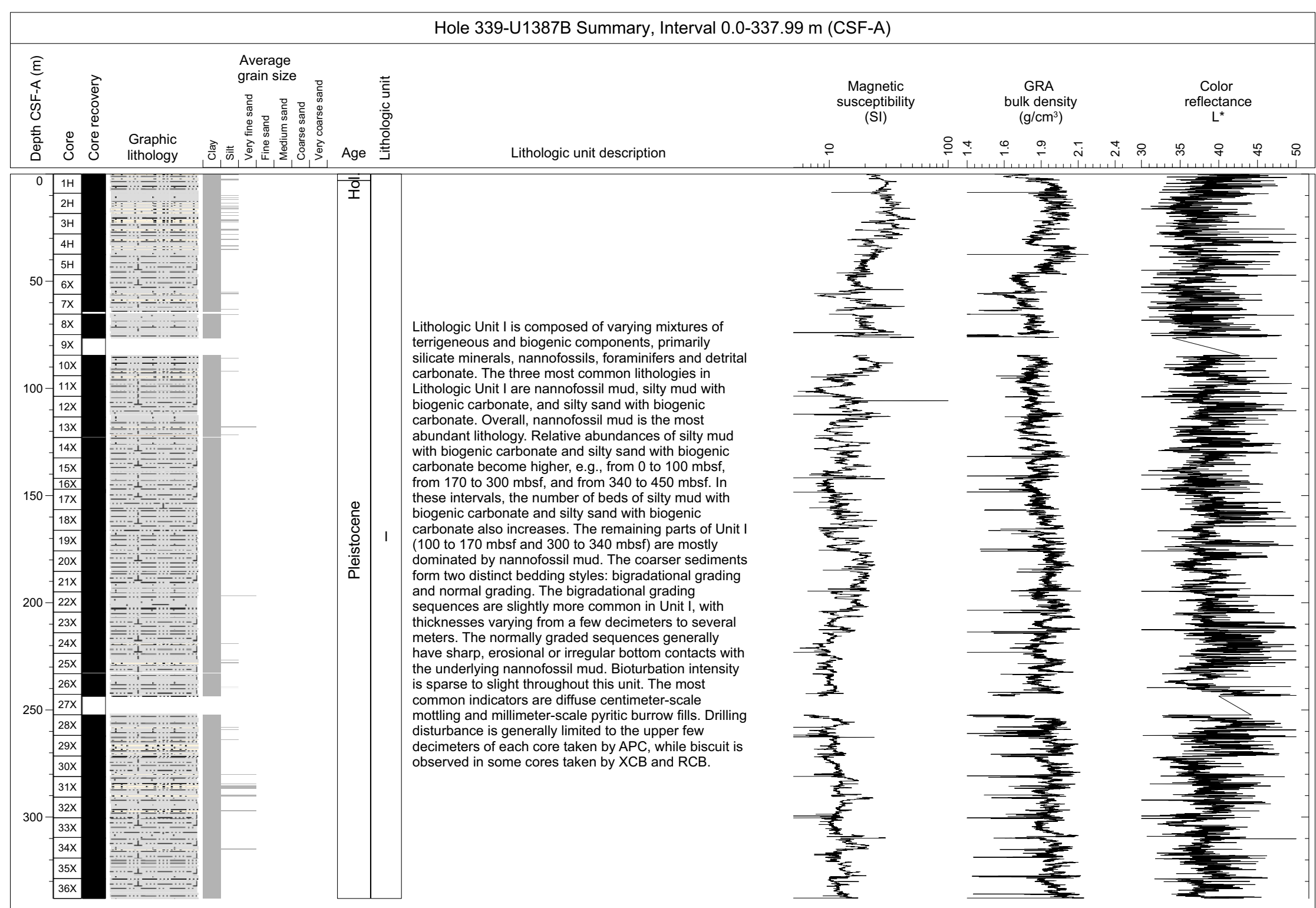


Figure F2 (continued). C. Hole U1387C.

C

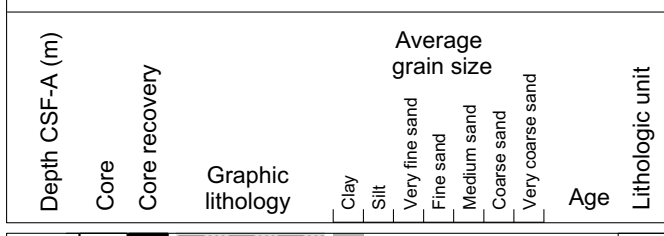
\begin{tabular}{l|l|l|}
\hline & Lithologic Unit Ii s composed of varying mixtures of
\end{tabular}

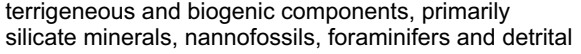
carbonate. The three mostc commonn lithologies in
Litholocoic Unit lare nannofossil mud, silty mud with biogenic carbonate, and silty sand with biogen carbonate. Vyerall, nannoforssil mudis is the most
abundant tithology. Relative abundances of silty mud with biogenenic arbonate and silty sand with biogenic carbonate become higher, e.g., from 0 to 100 mbst,
from 170 to 0300 mbst, and from 340 to 450 mbs. In these intervals, the number of beds of sity mud with carbonate also increases. The remaining parts of Uniit (100 to $170 \mathrm{mbs}$ and 300 to $340 \mathrm{mbsf}$ ) are mostly dominated by nannofossil mudd. The coarser sediments
form two disisinct bedding styles: bigradadtional grading and normal readinin. The bigracadational grading sequences are sightly more common in Unit t, with thicknessese varying from a few decimeters to severa

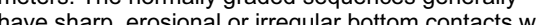
have
the underlying nannofossil mud Bioturnation nintensity is sparse to sight throughout this unit. The most

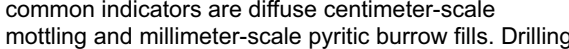
disturbance is generally linited to the upper few decimeters of each core taken by APC, while biscult
observed in some cores taken by XCB and RCB.

Lithologic Unitt lis composed of the same sediment

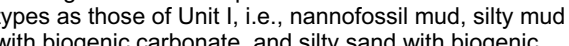
carbonate, but is discriminated from Unit I based on a clear cyclicity of dark and light colors in Unit II. Presence of dark color mud (very dark greenish gray
nannofossil mud) characterizes Unit I. Typically one cycle is composed of the following lithologies from top to bottom: very dark greenish gray nannofossil mud, overlying greenish gray to dark greenish gray nannofossli mud, overlying greenish gray to dark

overlying greenish gray to dark greenish gray silty sand with biogenic carbonate. The basal contact of the silty sand with biogenic carbonate generally is sharp or trace amount of siliceous microfossils, such as diatom and sponge spicules. Approximately 50 cycles are recognized in Unit 11. Cycle thicknesses vary from 1 to

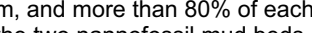

The top of Unit II is defined at $454.06 \mathrm{mbsf}$
$(339-\mathrm{U} 1387 \mathrm{C}-19 \mathrm{R}-1,106 \mathrm{~cm})$, at the top of the

shallowest bed of very dark greenish gray nannofossil mud more than $1 \mathrm{~m}$ thick. This depth is also near the
significant time gap between 3.19 and $>1$ dolostone beds are present near the top of Unit II, at 457.3-458.0 and 462.7-462.8 mbsf. Very dark greenish gray muds immediately above $(339-\mathrm{U} 1387 \mathrm{C}-19 \mathrm{R}-3$, dolostone contain very rare and no nannofossils,

Lithologic Unit III is composed mainly of nannofossil wad, sily mud wish biogenic carbonale, and silty sand distinguished from the other units by 1 ) the presence of contorted mud beds, 2) the increased abundance of coarser lithologies, and 3) the presence of sandstone

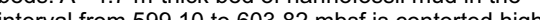
including recumbent fold limbs up to $50 \mathrm{~cm}$ thick. This bed is interpreted as a slump deposit, and the top of this contorted bed deffines the top of Unit til. Simlar contorted beds, which are recognizable as intra-bed
recumbent folds and/or inclined laminae, are observed throughout Unit III. Beds of very dark greenish gray silty sand with biogenic carbonate, about $30-120 \mathrm{~cm}$-thick,
also characterize Unit III. These layers contain also characterize Unit III. These layers contain
abundant shell fragments and a few granules, which abundant shell fragments and a few granules, which
are generally rounded, and composed mainly of quartzite with trace metamorphic rock fragments. Muddy/sity sandstone and medium sandstones are
present in $692.90-722.09$ mbsf and 748.10 to 750.92 mbs. Al interlaminated silty sand and te The bottom of Unit III is at $750.92 \mathrm{mbsf}$, Section
$339-\mathrm{U} 1387 \mathrm{C}-50 \mathrm{R}-1,52 \mathrm{~cm}$, which is the deepest $339-U 1387 \mathrm{C}-50 \mathrm{R}-1,52 \mathrm{~cm}$, which is the deepest
occurrence of sandy sediment. Bioturbation is absent in occurrence of sandy sediment. Bioturbation is absent in intensity is generally sparse to slight in the other sediments. Biscuitting is formed in some cores.
Sandstones are fragmented into small pieces.

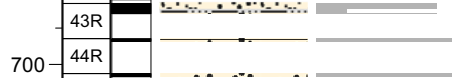

\begin{tabular}{ll}
$45 R$ \\
$46 R$ \\
\hline
\end{tabular}

$48 \mathrm{~B} \quad \equiv::: \cdots::=: \cdots$ 750

恓

R $=$

韭!:

800

Q

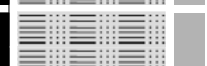

国:

$850-60$

\begin{tabular}{|l|l|}
\hline 60R \\
\hline 618
\end{tabular}

$+1 \mid+$

The dominant lithology within Unit IV is nannofossil mud and muddy/clayey nannofossil ooze. In the upper part of this unit, from Section $339-\mathrm{U} 1387 \mathrm{C}-50 \mathrm{R}-1,52 \mathrm{~cm}$ to $-55 R-4,26 \mathrm{~cm}$, very thin beds (2 cm thick) of dark
greenish gray silty sand with biogenic carbonate and

greenish gray sity sand with biogenic carbonate and
$<1.2 \mathrm{~m}$ thick beds of dark greenish gray sitty mud with biogenic carbonate are interbedded with thick beds $(>1$ $m$ thick) of dark to very dark greenish gray nannofossil
mud. Some dark-light cycles which were seen in Unit II, are also present from Section 339-U1387C-50R-1 to

$\mathbb{E}$
$\mathbb{8}$ IV $\begin{aligned} & 52 R-3.3 \text { The deepest occurrence of thick bed of silty mud } \\ & (\sim 80 \mathrm{~cm} \text { thick }) \text { is at Section 339-U1387C-55R-3 and }-4 \text {. }\end{aligned}$ The middle part of this unit (Section 339-U1387C$55 \mathrm{R}-4,26 \mathrm{~cm}$ to $-58 \mathrm{R}-\mathrm{CC}, 28 \mathrm{~cm}, 803.16$ to 834.38
mbsf) is dominated by dark greenish

mbst) is dominated by dark greenish gray nannofossil
mud, and the lower part of this unit (Sections $339-\mathrm{U} 1387 \mathrm{C}-59 \mathrm{R}-1,0 \mathrm{~cm}$ to $-61 \mathrm{R}-\mathrm{CC}, 16 \mathrm{~cm}$ (836.80 to $865.85 \mathrm{mbsf})$ ) is dominated by dark greenish gray
clayey/muddy nannofossil ooze. Bioturbation intensity is clayey/muddy nannofosst
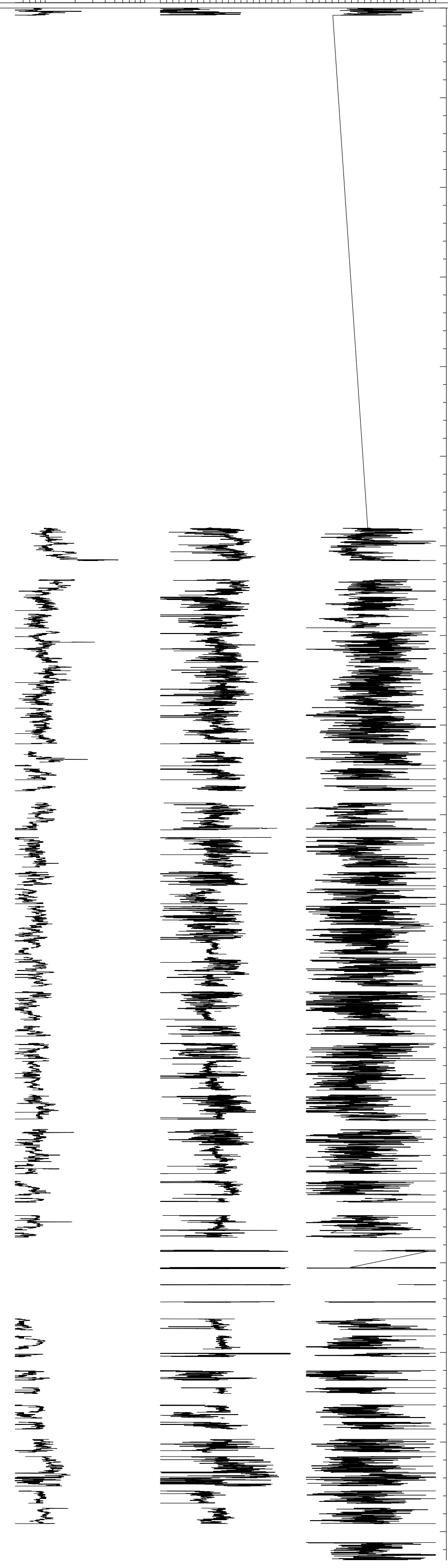

$\begin{array}{ccc}\begin{array}{c}\text { Magnetic } \\ \text { susceptibility }\end{array} & \text { GRA } & \text { Color } \\ \text { (SI) } & \text { bulk density } & \text { reflectance } \\ \mathrm{L}^{*}\end{array}$

$\circ \quad 8+$

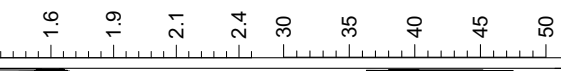


Figure F3. Plots of downhole variations in lithology, Site U1387.

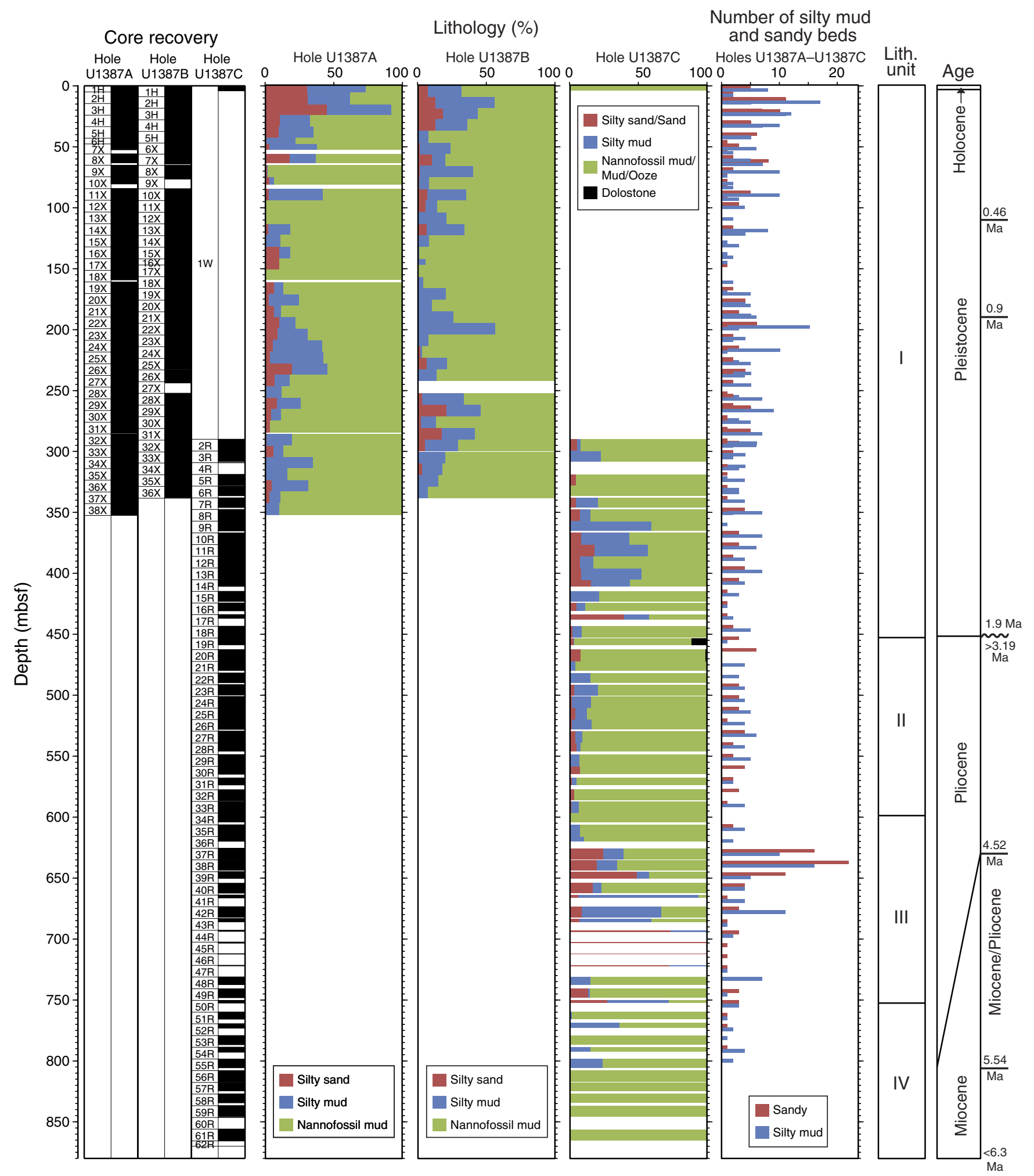


Figure F4. Core images of typical bi-gradational silty sand bed in Unit I (Sections 339-U1387B-33X-6A and 7A).

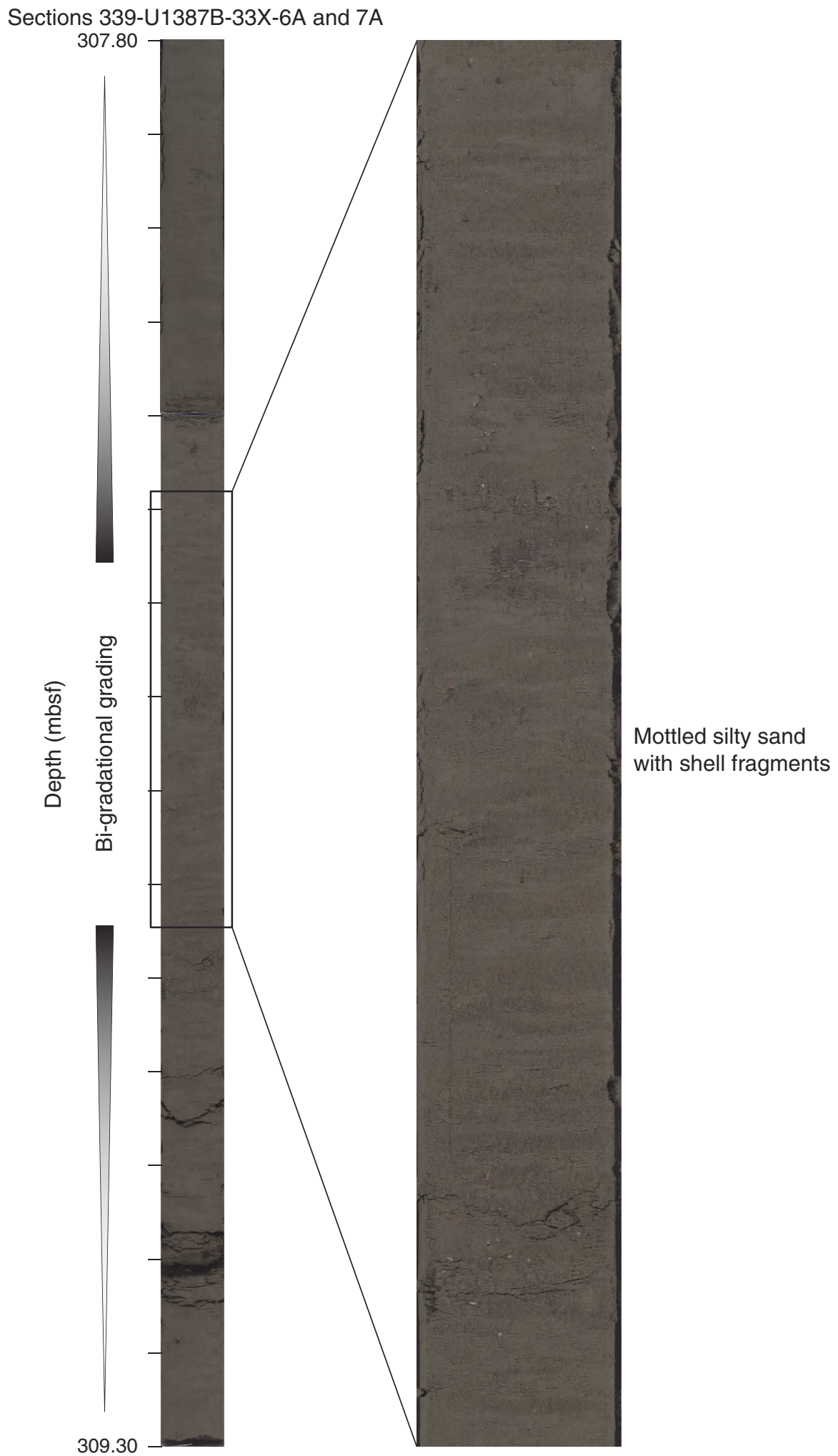


Figure F5. Core images of typical normally graded silty sand beds in Unit I (Sections 339-U1387A-24X-7A and 339-U1387B-24X-4A).

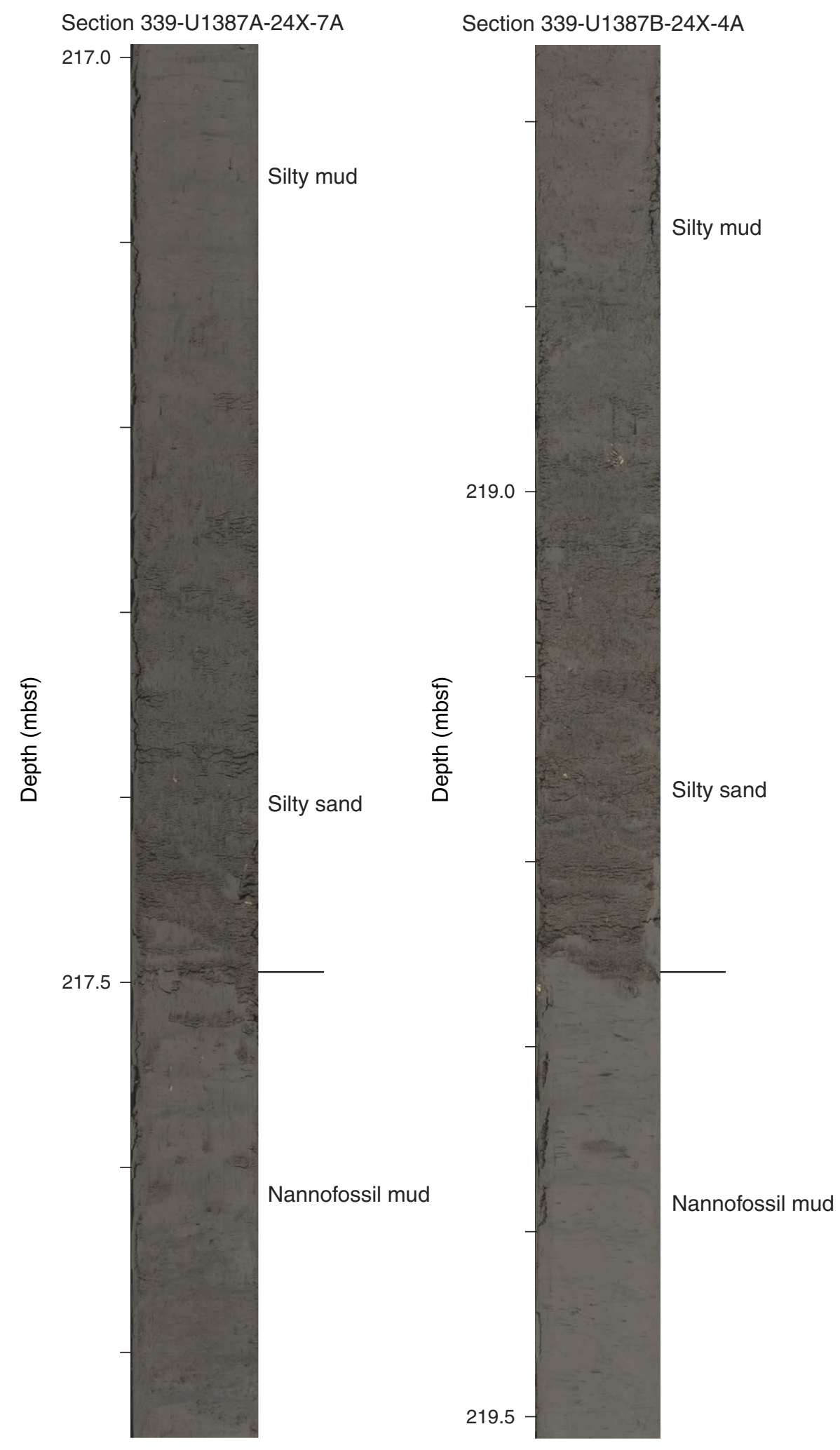


Figure F6. Core images of dark-light cycles and lithologic boundaries in Unit II (Sections 339-U1387C-29R-5A and 29R-6A). A. Boundary between very dark greenish gray nannofossil mud and underlying greenish gray nannofossil mud. B. Boundary between greenish gray silty sand with biogenic carbonate and underlying very dark gray nannofossil mud.

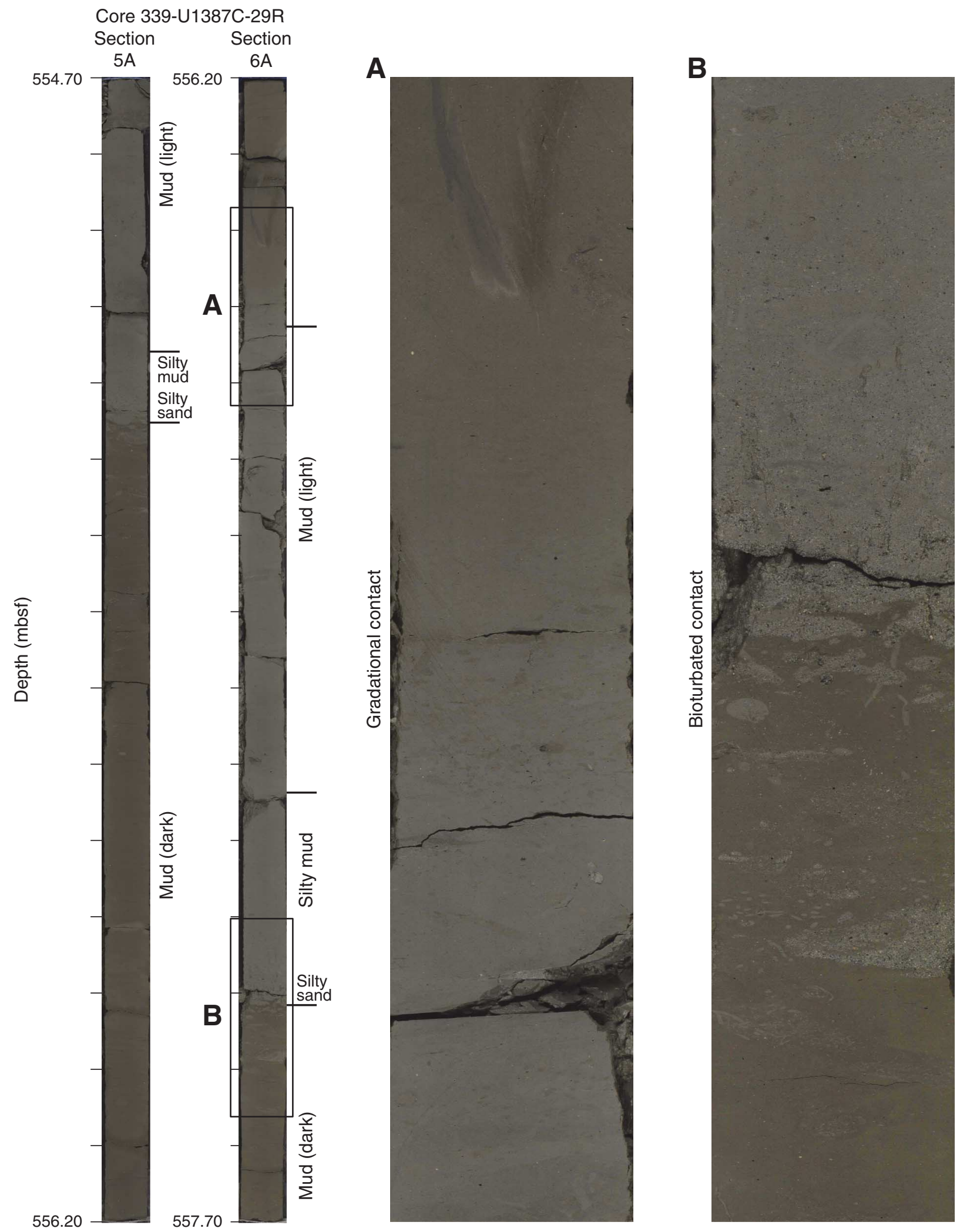


Figure F7. Core images and photomicrographs of the upper dolostone bed and overlying and underlying mud beds (Sections 339-U1387C-19R-3A and 19R-4A). A. Mud above the dolostone. B. Dolostone. C. Mud below the dolostone. Left panels taken under plane-polarized light; right panels taken under cross-polarized light. Scale bars $=200 \mu \mathrm{m}$.

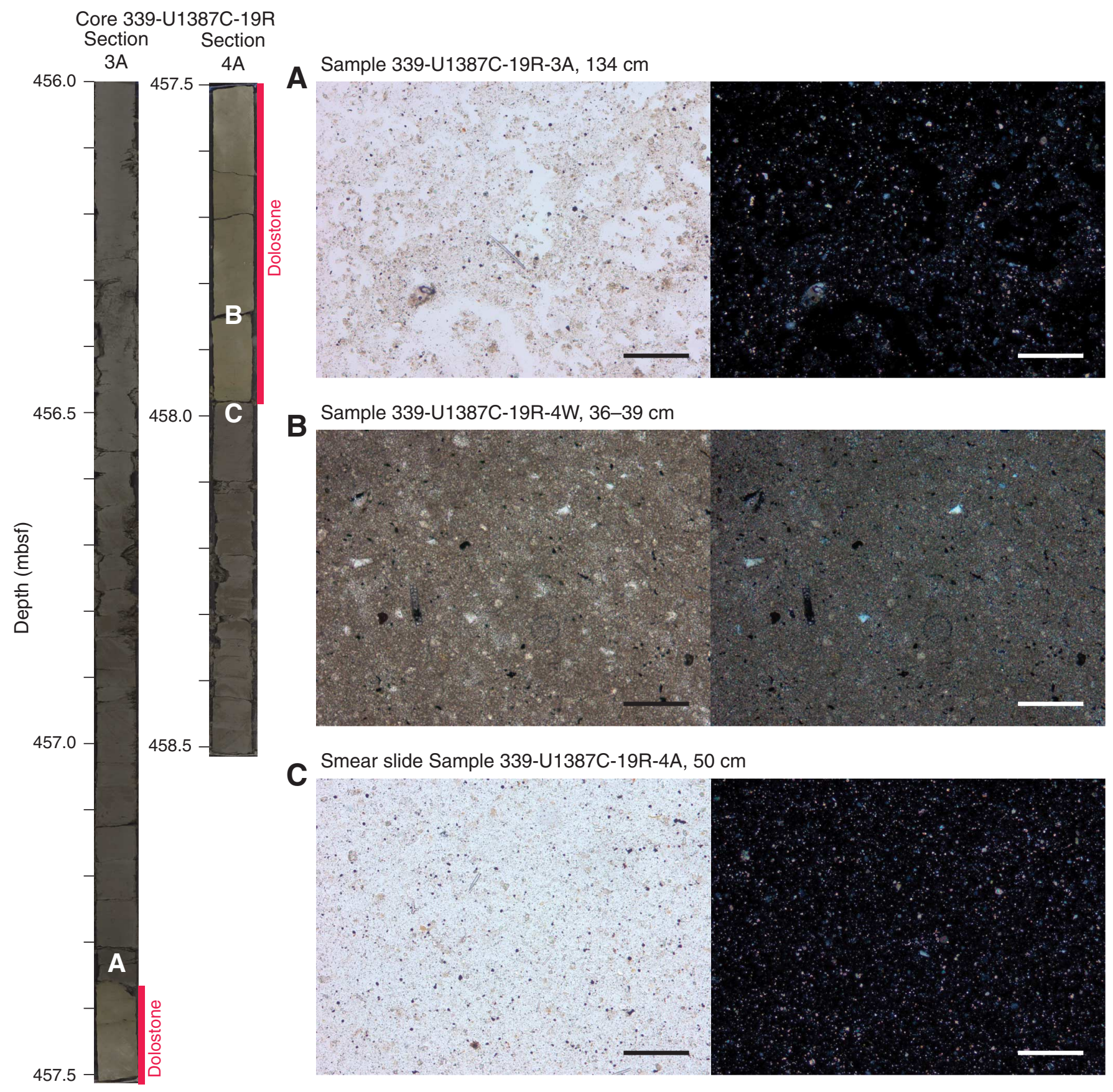


Figure F8. Core images of soft-sediment deformation in the nannofossil mud in Unit III (Sections 339-U1387C34R-2A through 34R-5A).

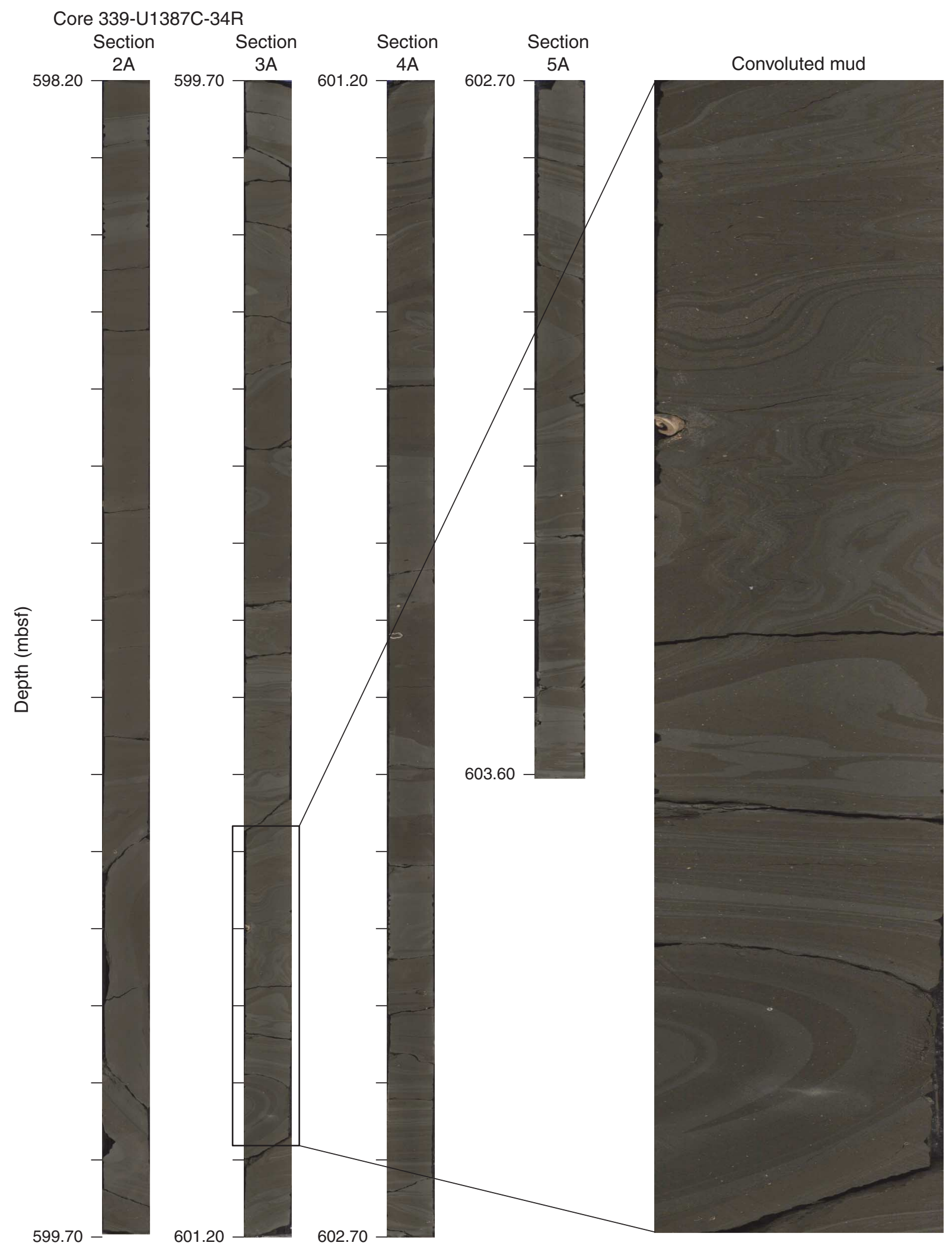


Figure F9. Core images and photomicrographs of sandstone in Unit III (Sections 339-U1387C-44R-1A and 45R1A). A. Dark greenish gray silty sandstone. B. Gray medium sandstone. Upper panels taken under plane-polarized light; lower panels taken under cross-polarized light. Scale bars $=100 \mu \mathrm{m}$.

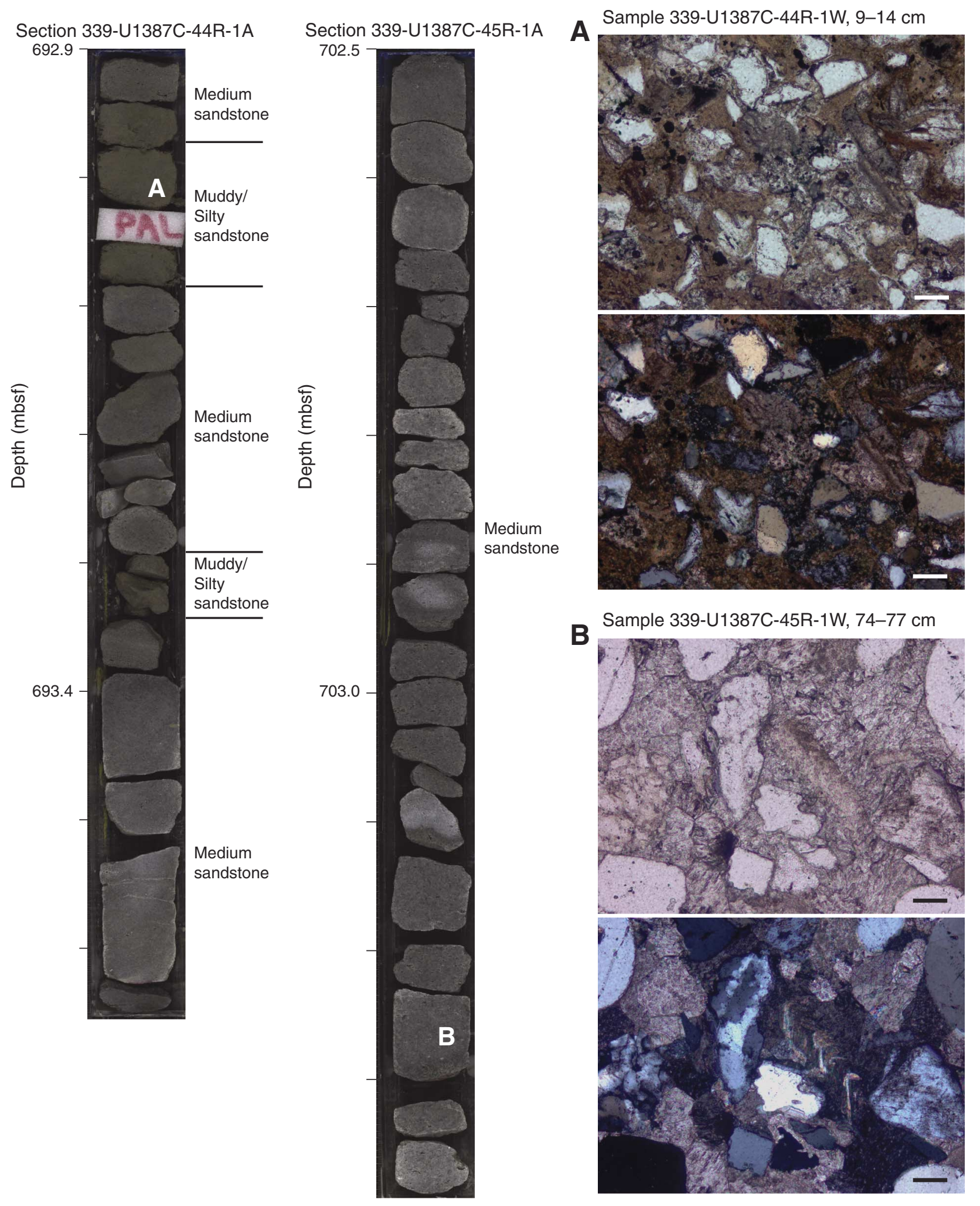


Figure F10. Core images of typical nannofossil ooze in Unit IV (Sections 339-U1387C-61R-2A through 61R-4A).

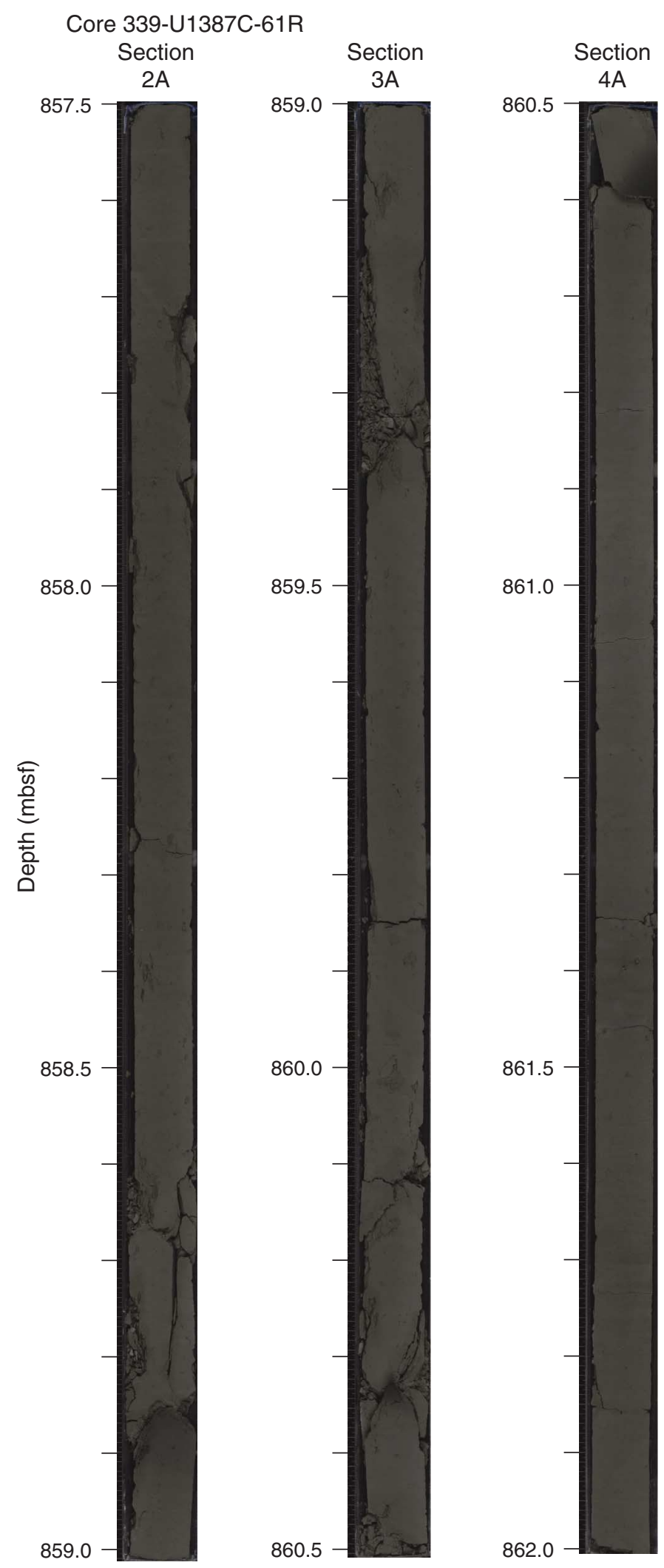


Figure F11. Photomicrographs of smear slides of (A) typical nannofossil mud (Sample 339-U1387A-33X-5A, 73 $\mathrm{cm}$ ) and (B) silty sand with biogenic carbonate (Sample 339-U1387A-33X-6A, $80 \mathrm{~cm}$ ). Left panels taken under plane-polarized light; right panels taken under cross-polarized light. Scale bars $=200 \mu \mathrm{m}$.
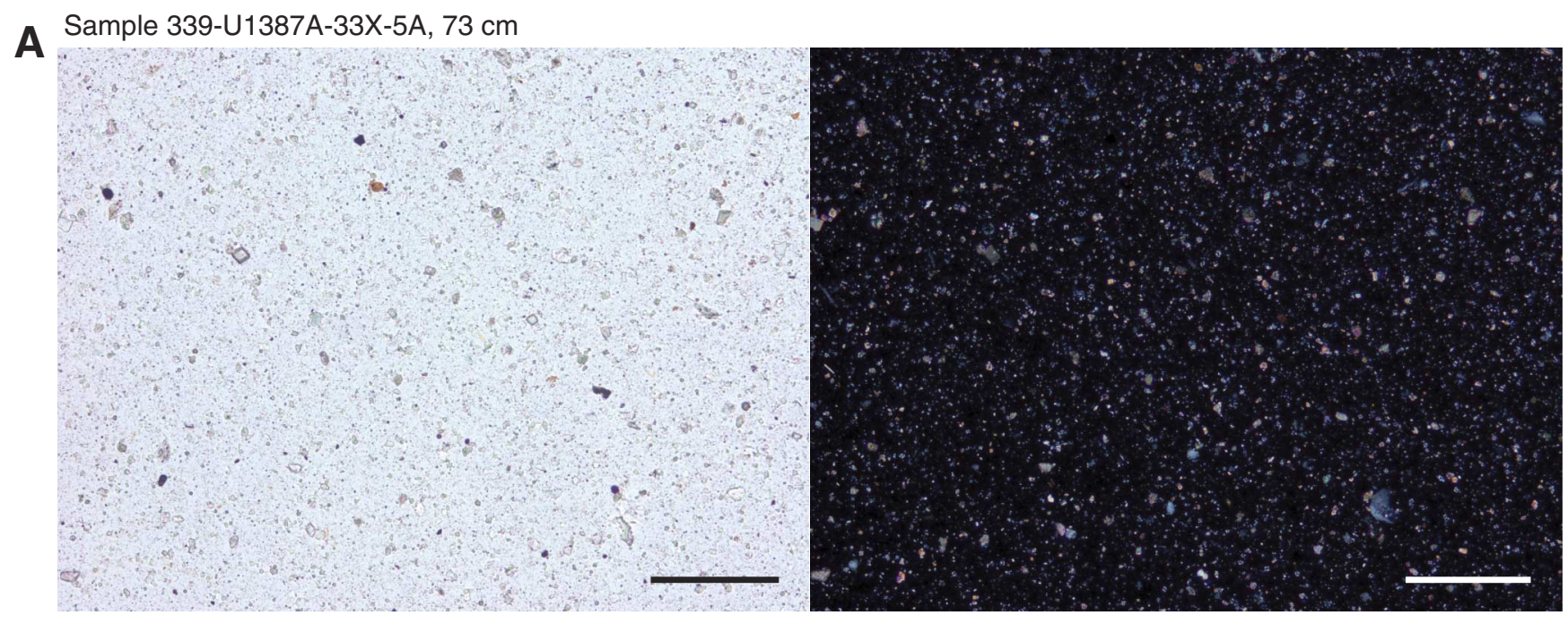

B Sample 339-U1387A-33X-6A, $80 \mathrm{~cm}$

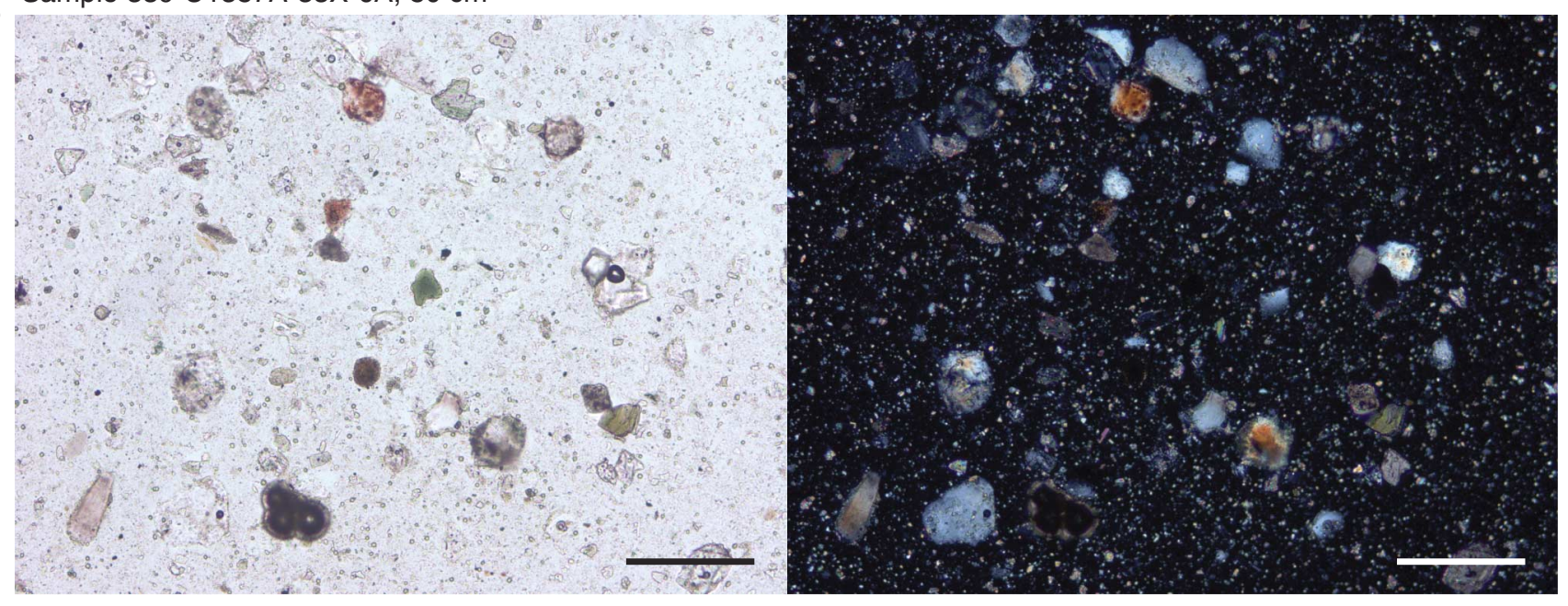


Figure F12. Plots of downhole lithology percentages comparing Sites U1386 and U1387.

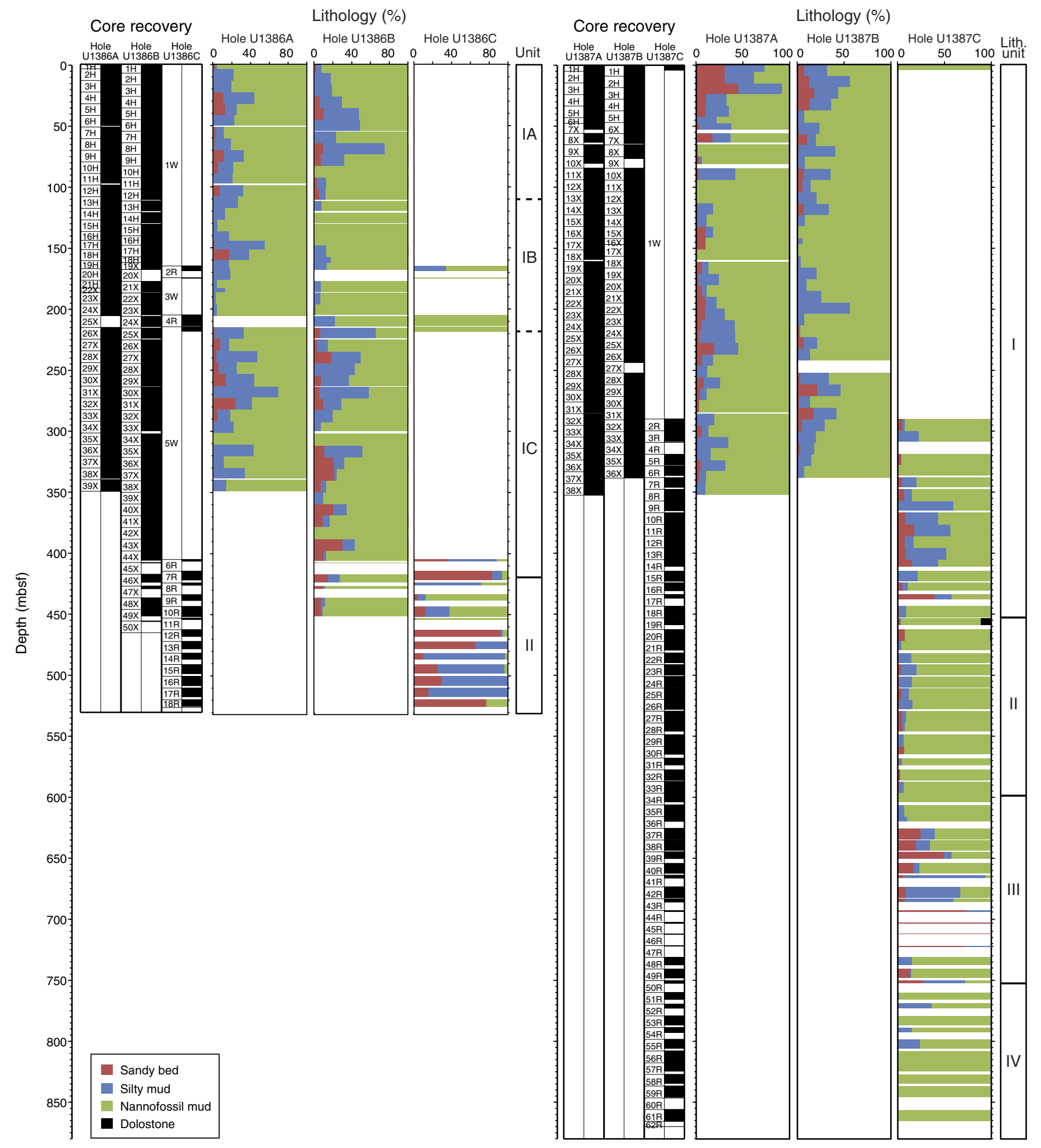


Figure F13. Plots of smear slide relative abundances in fine- and coarse-grained sediment, Site U1387A.

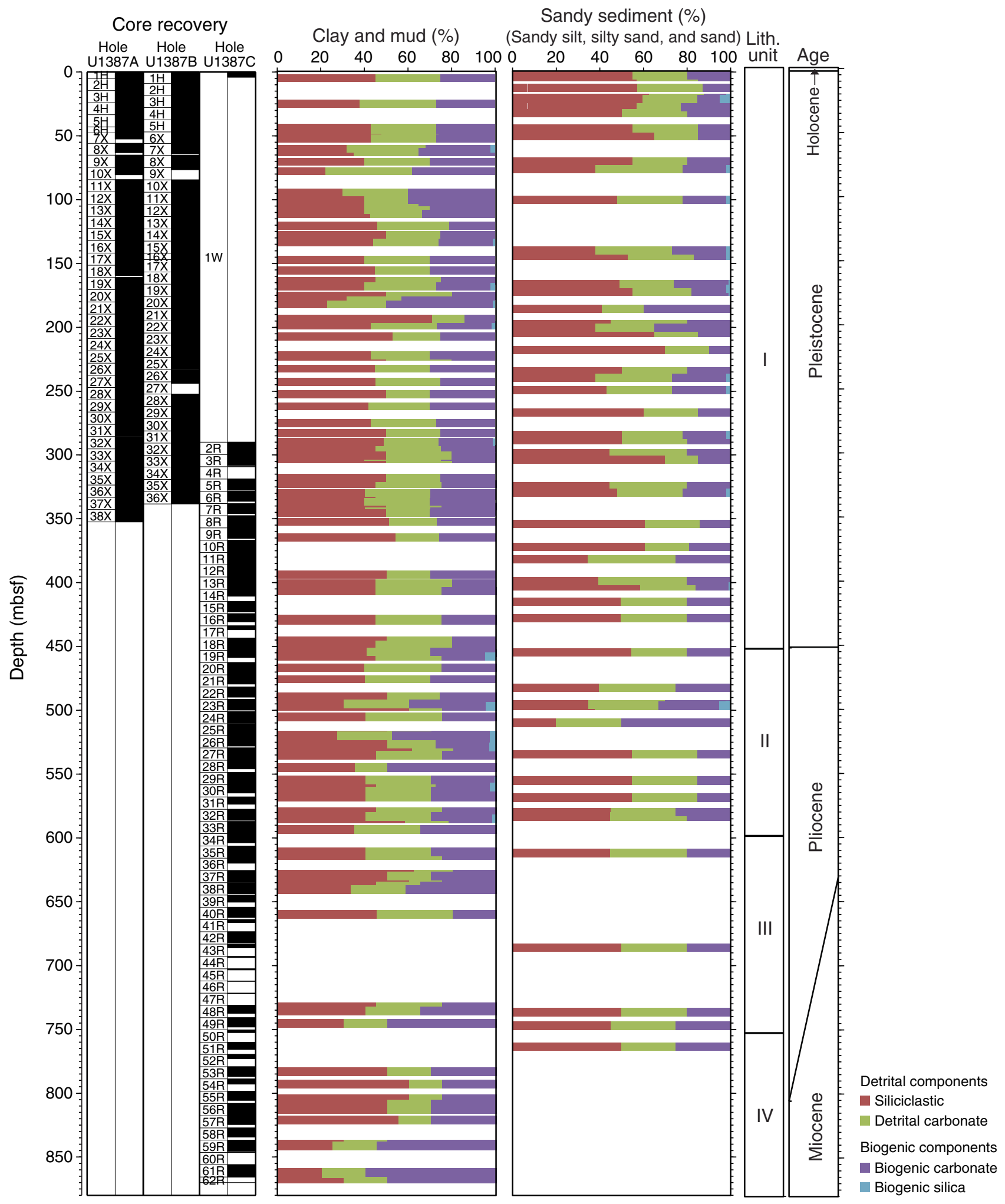


Figure F14. Photographs of gastropod shells from Unit I (Samples 339-U1387B-2H-6, 129-131 cm, and 339U1387A-30X-CC, 32-33 cm, and 9X-2, 111-112 cm).
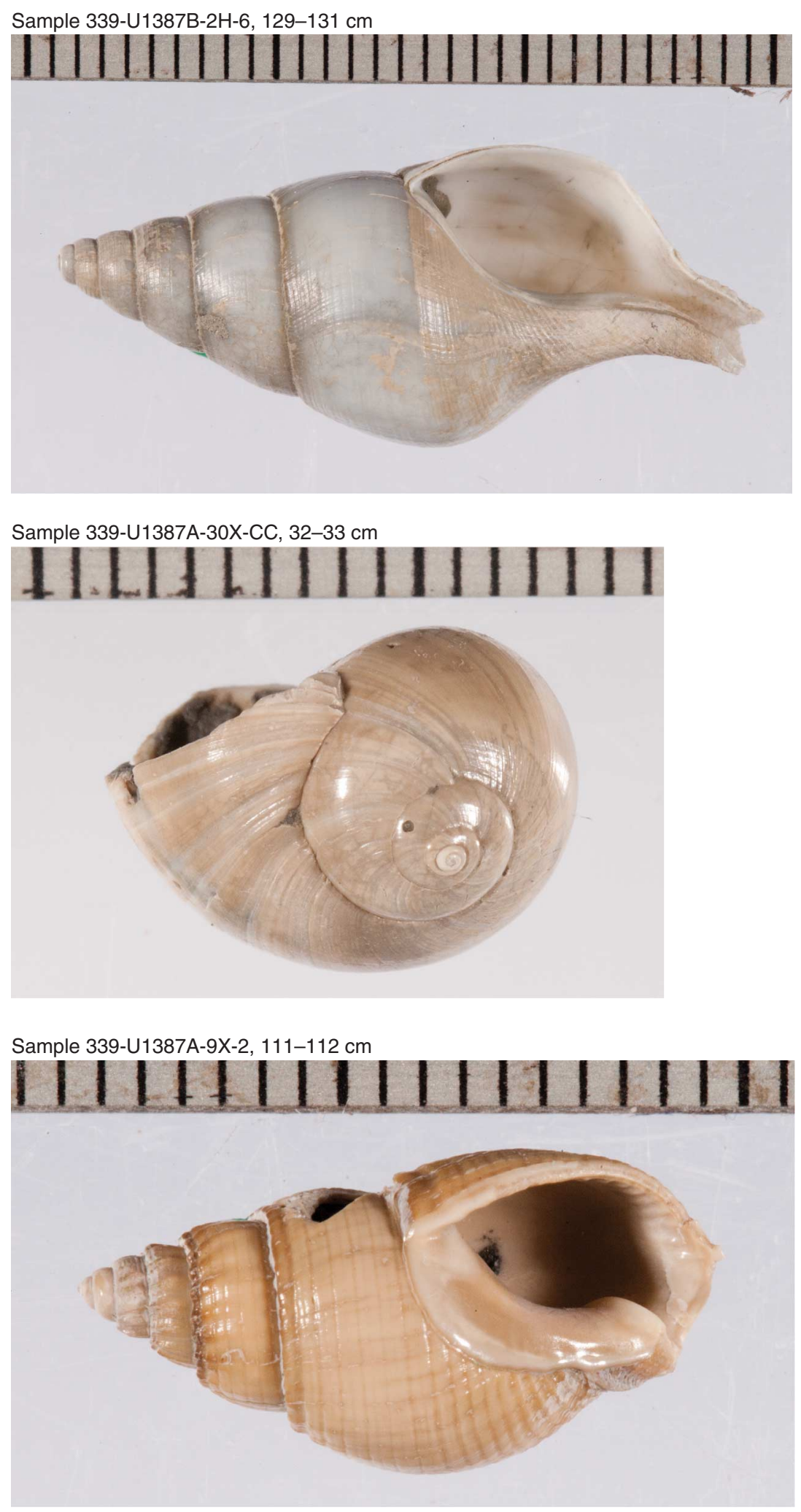
Figure F15. Photographs of coral fragments from Unit I (Samples 339-U1387A-1H-4, 25-27 cm; 5H-1, 73-74 $\mathrm{cm} ; 6 \mathrm{H}-1,31-32 \mathrm{~cm}$; and 9X-5, 92-93 cm).
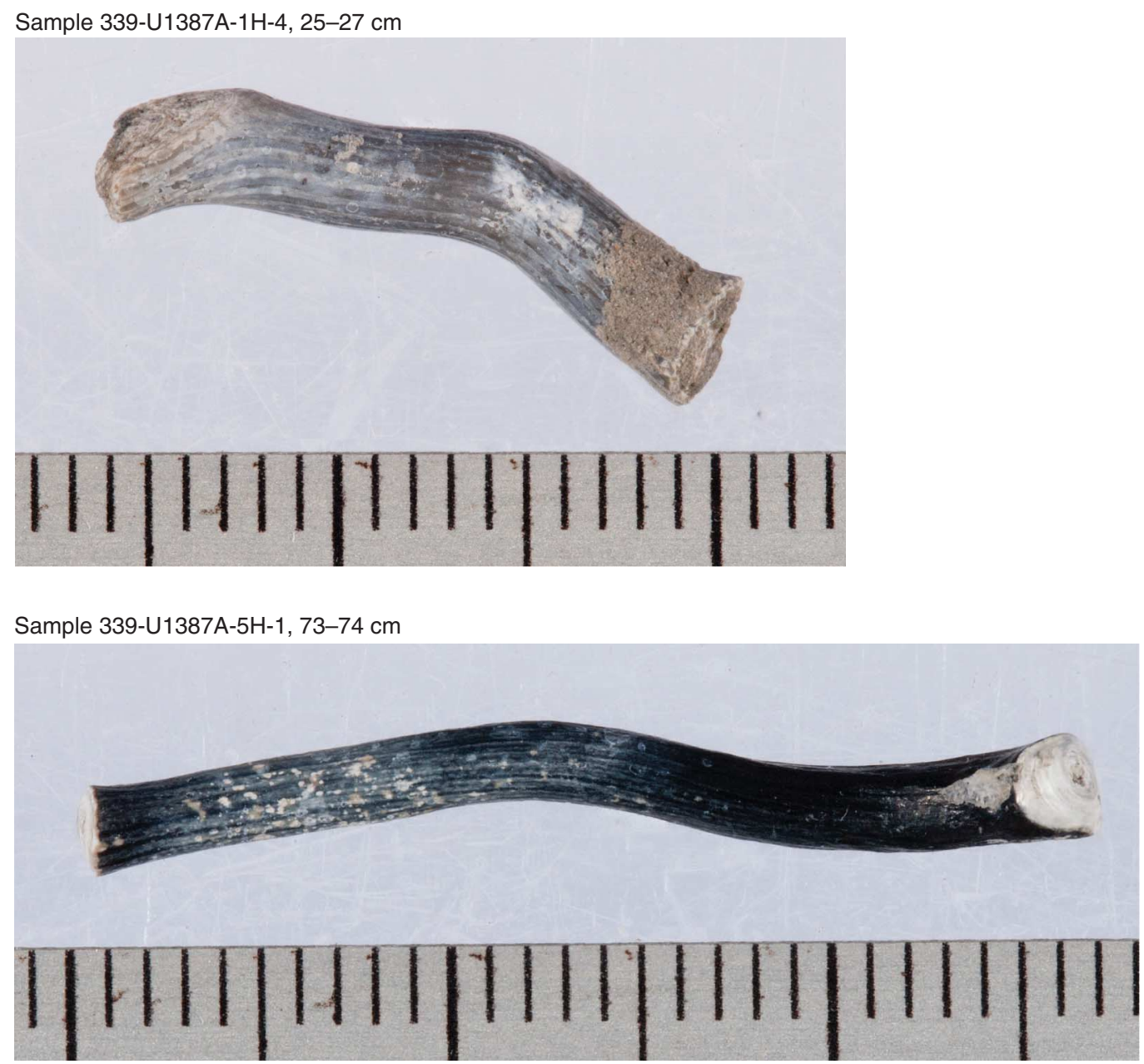

Sample 339-U1387A-6H-1, 31-32 cm

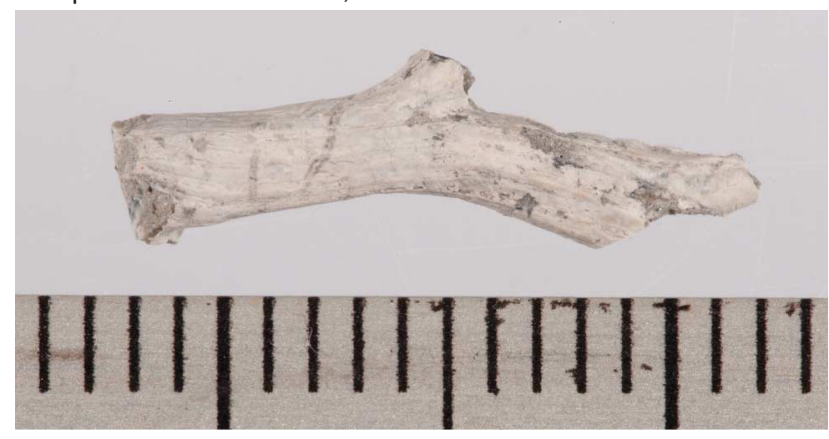

Sample 339-U1387A-9X-5, 92-93 cm

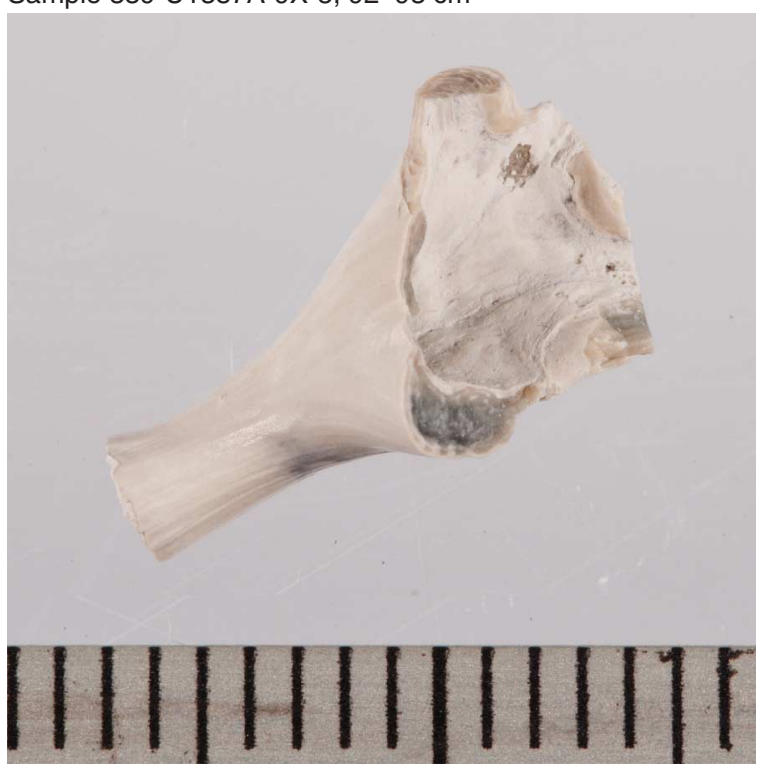


Figure F16. Photograph of Arenaria from Unit I (Sample 339-U1387B-1H-3, 42-43 cm).

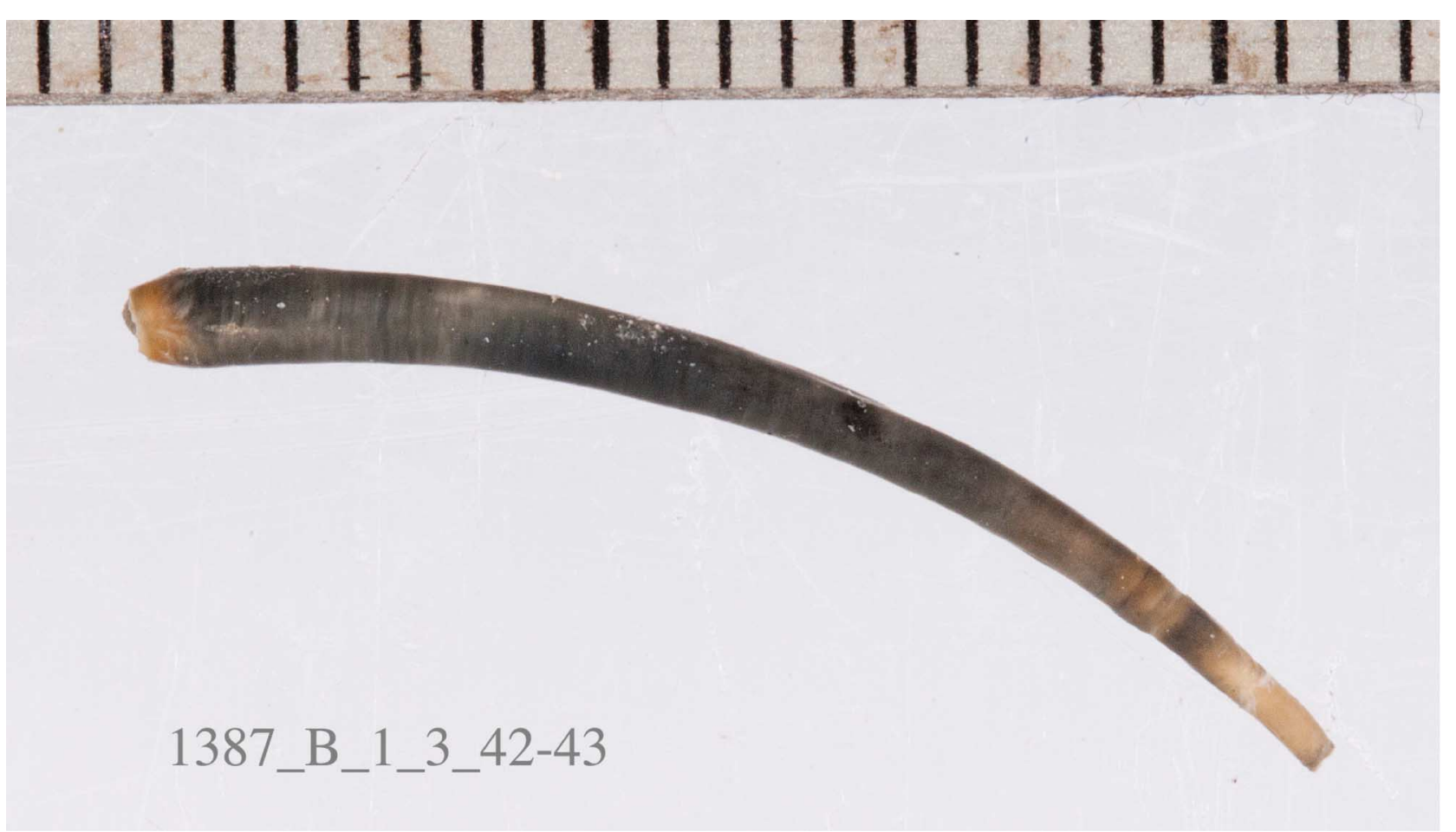


Figure F17. Photographs of bivalve shells from Unit I (Samples 339-U1387A-2H-4, 108-110 cm; 7X-1, 88-89 $\mathrm{cm}$; and 19X-2, 88-89 cm).

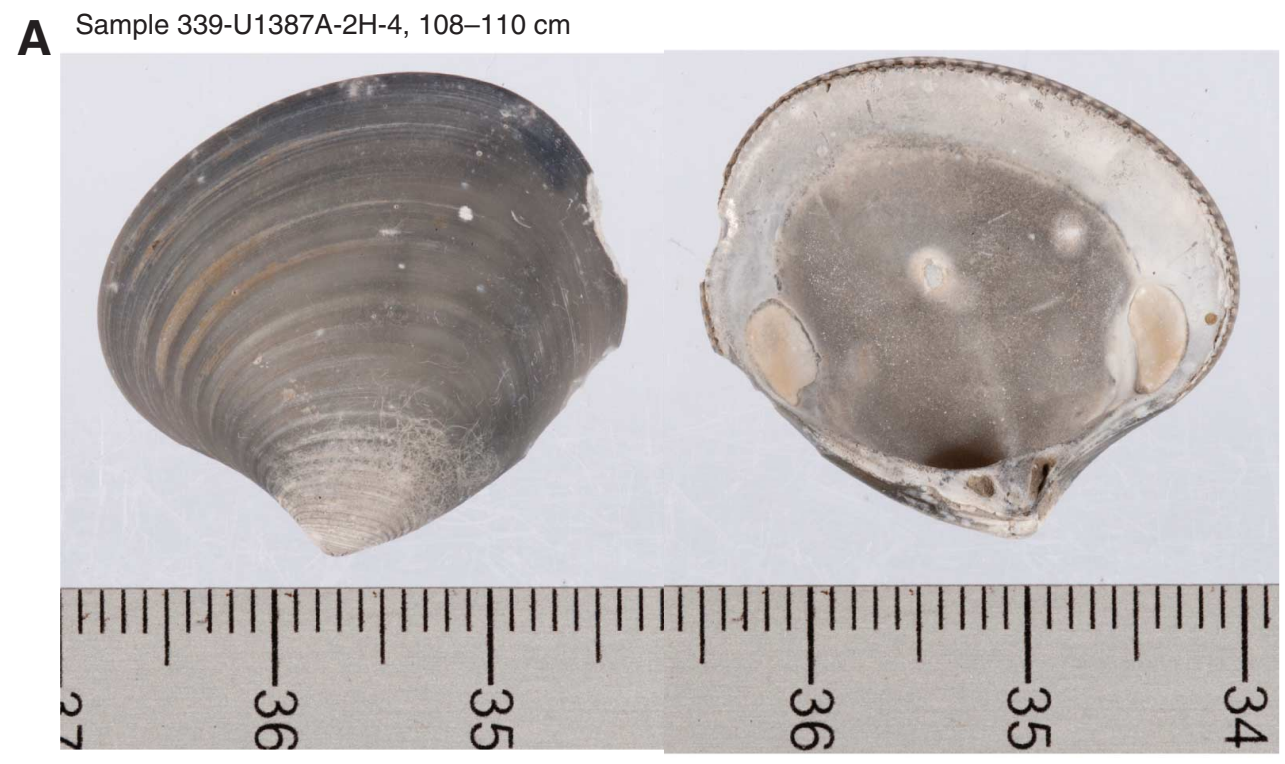

B Sample 339-U1387A-7X-1, 88-89 cm

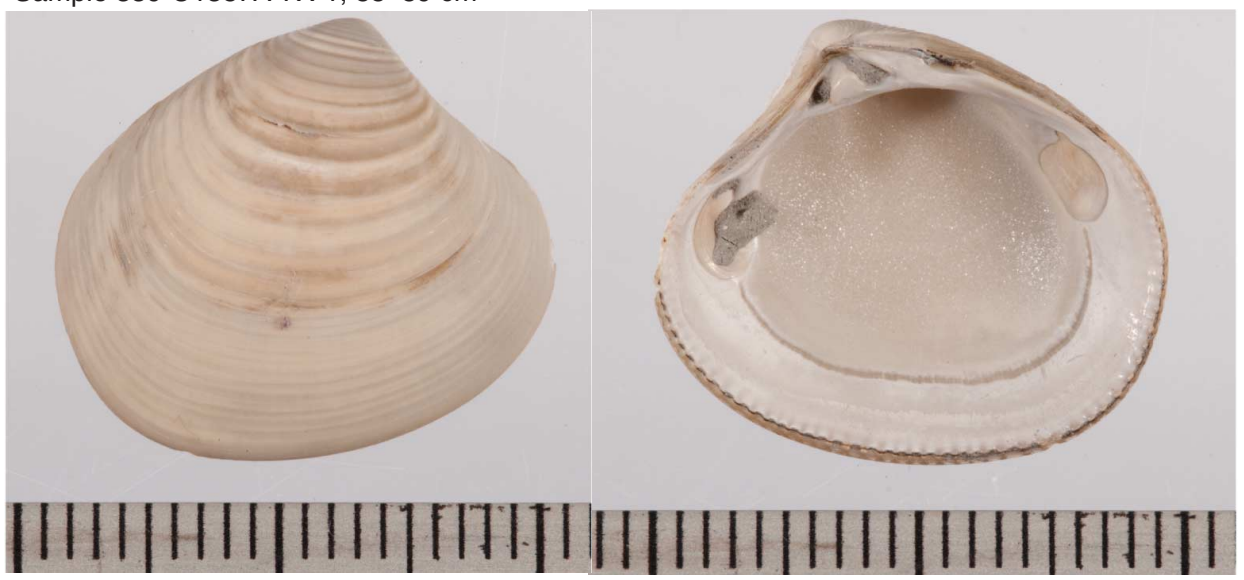

C Sample 339-U1387A-19X-2, 88-89 cm

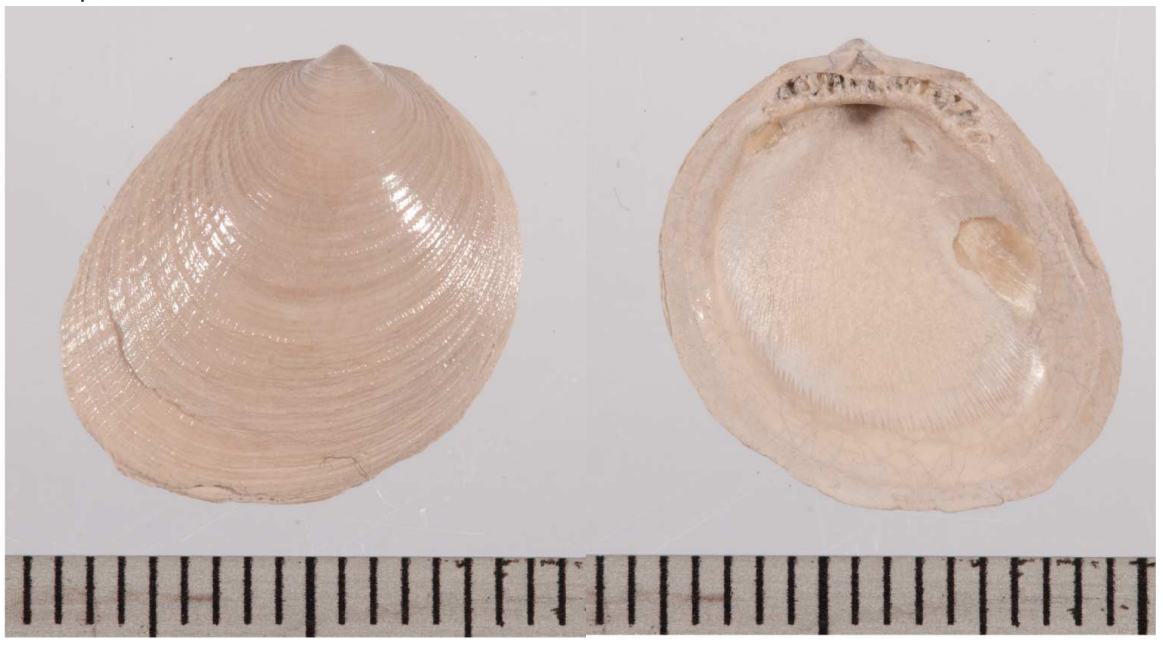


Figure F18. Photographs of vermetid-like fossils from Unit I (Sample 339-U1387A-1H-2, 55-57 cm).
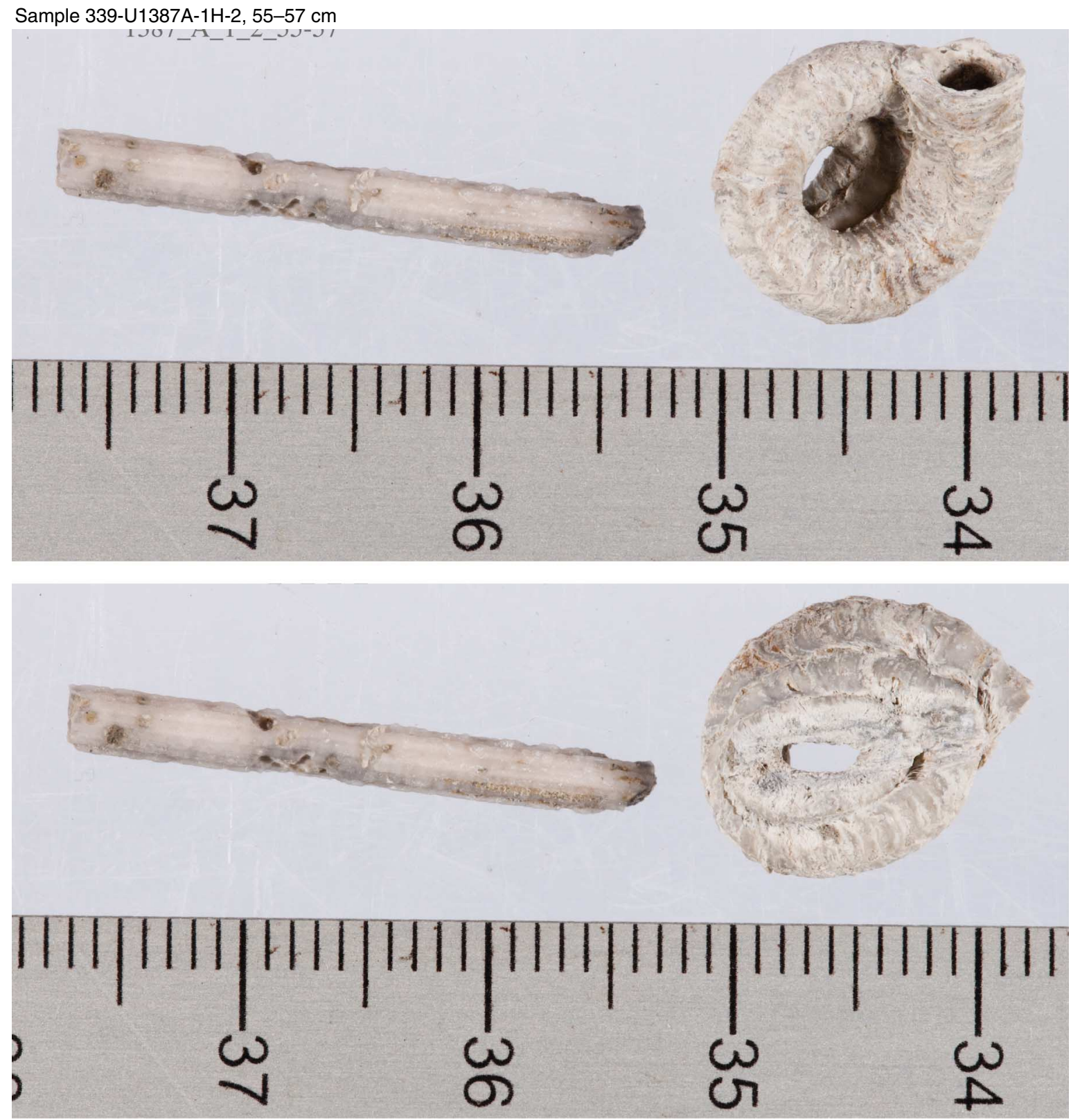


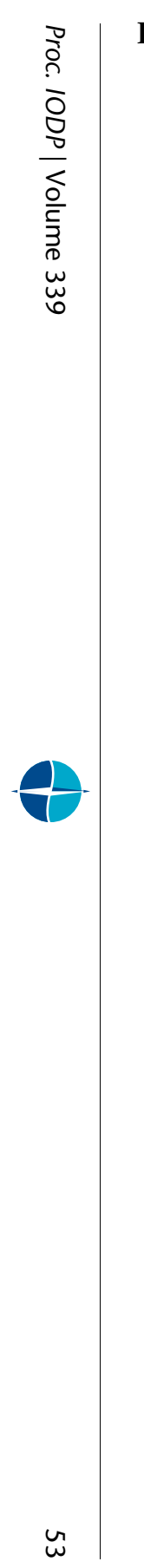

Figure F19. XRD peak intensity profiles, Site U1387.

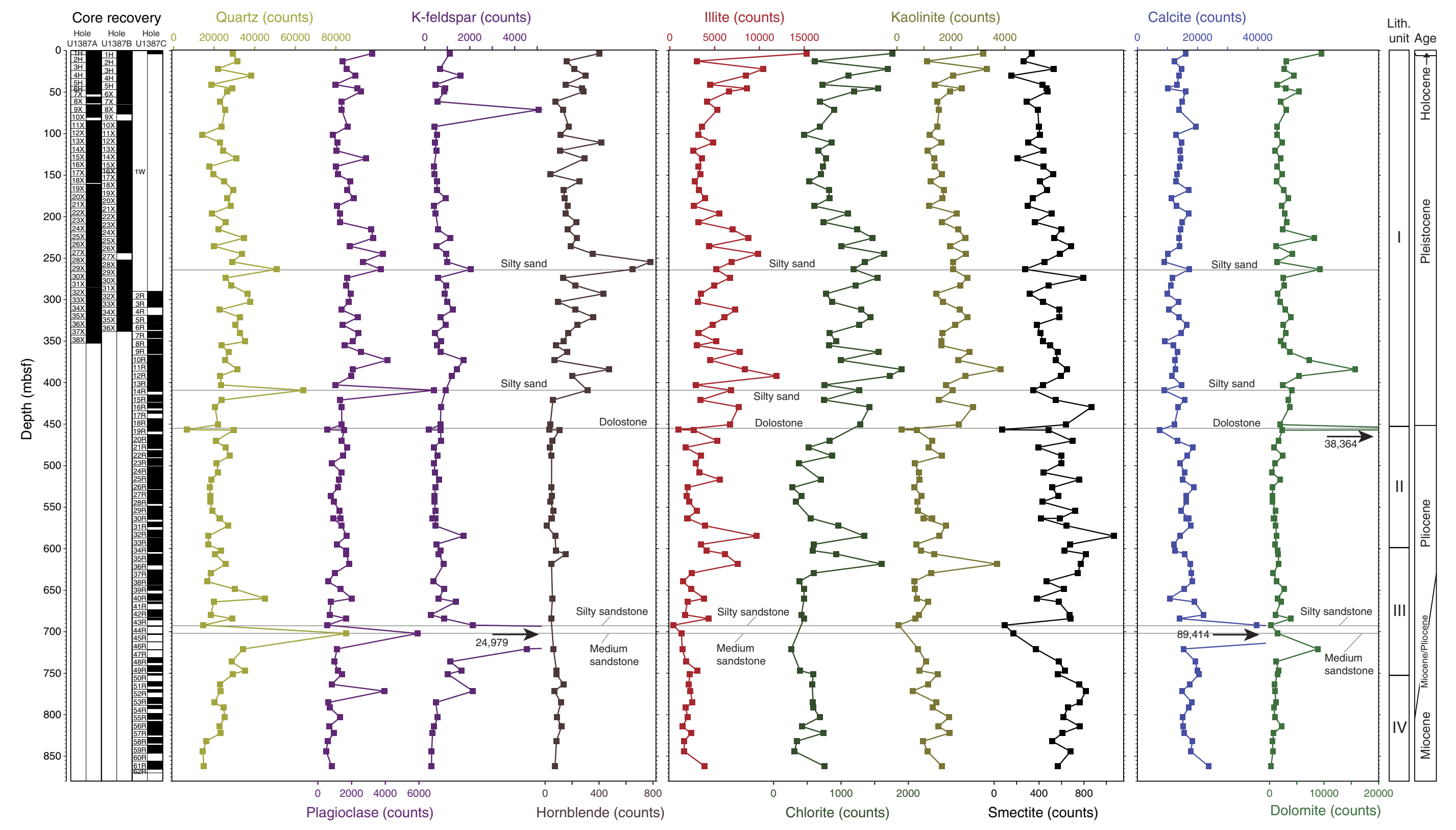



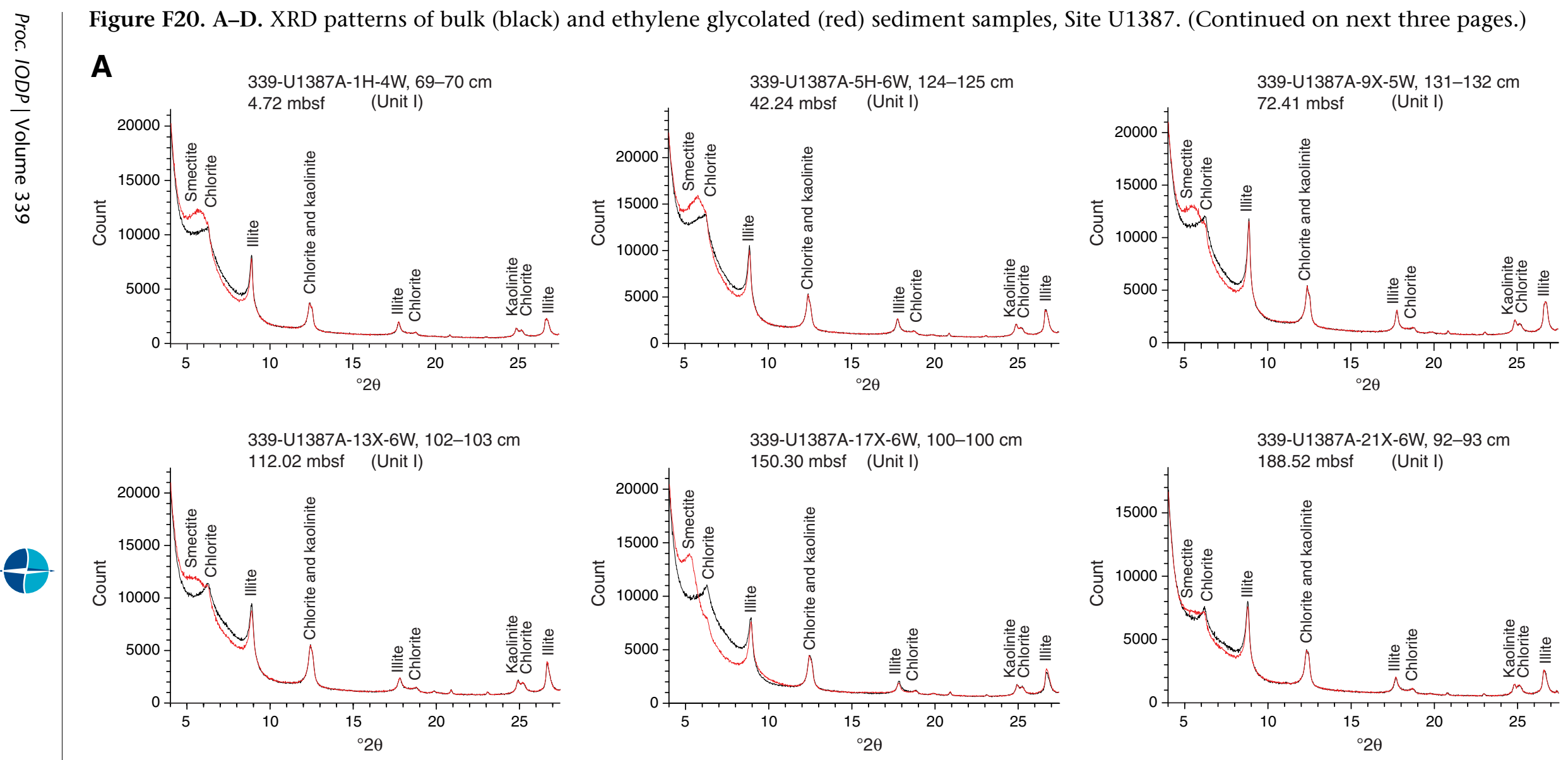

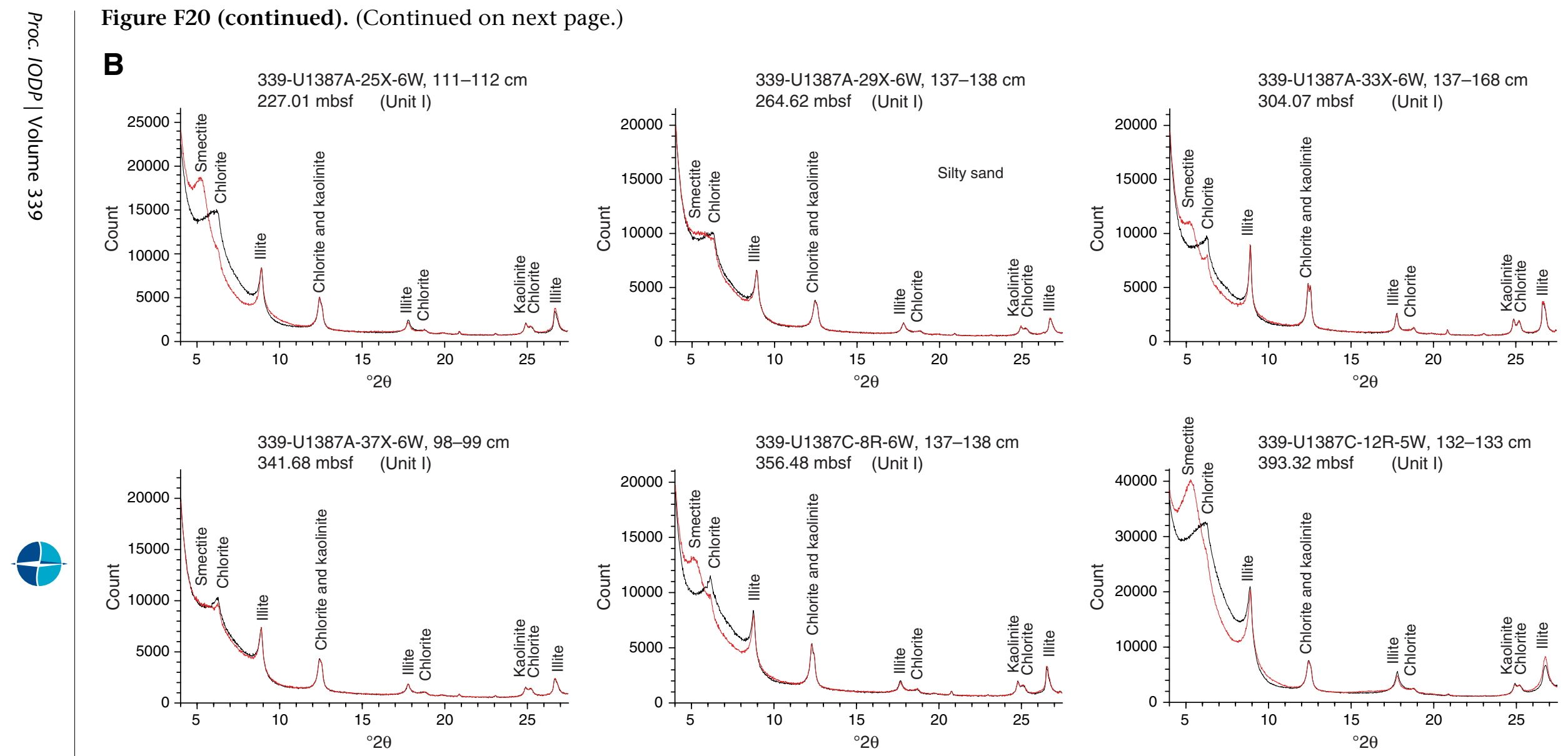

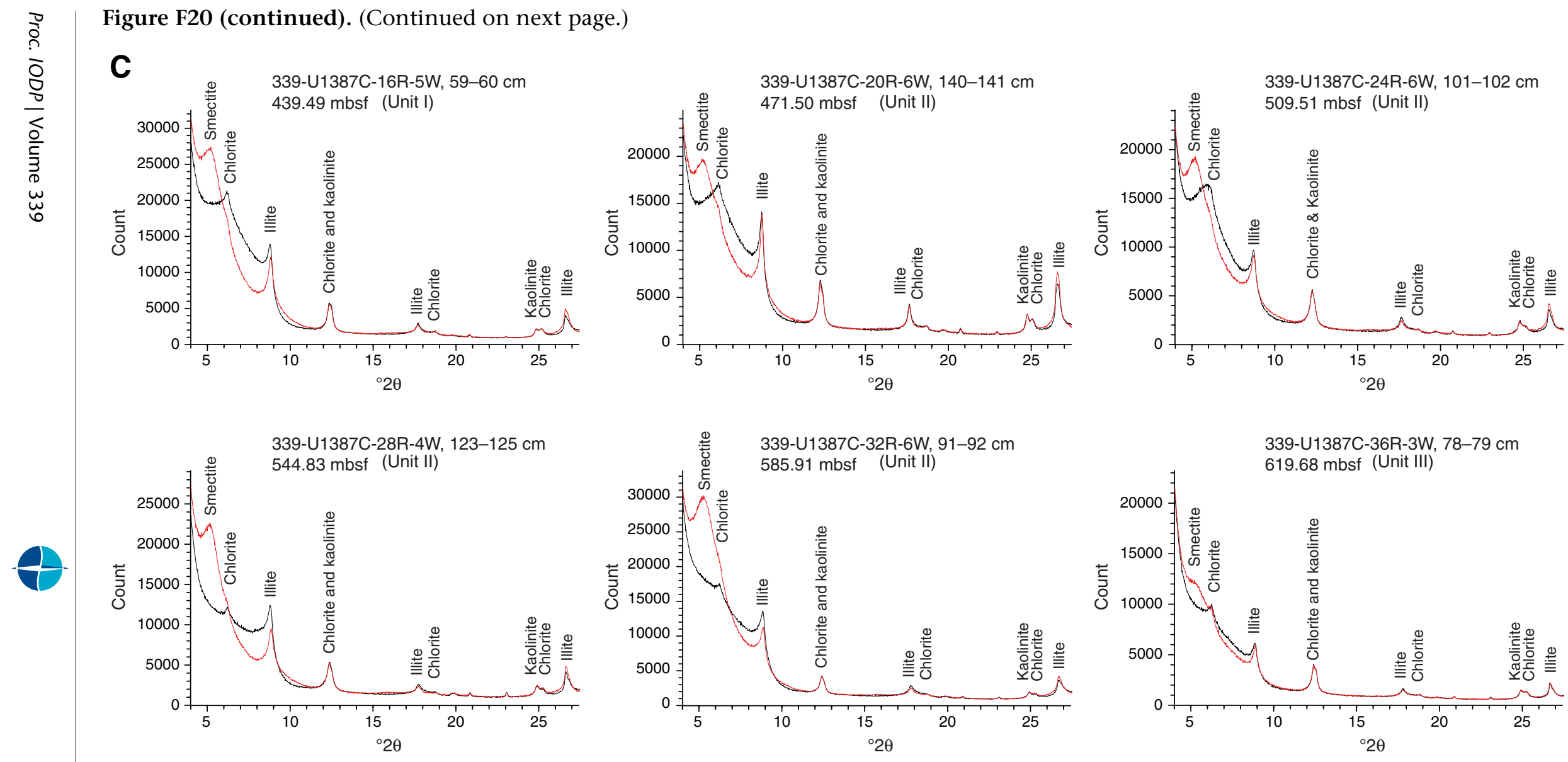
Figure F20 (continued).

D
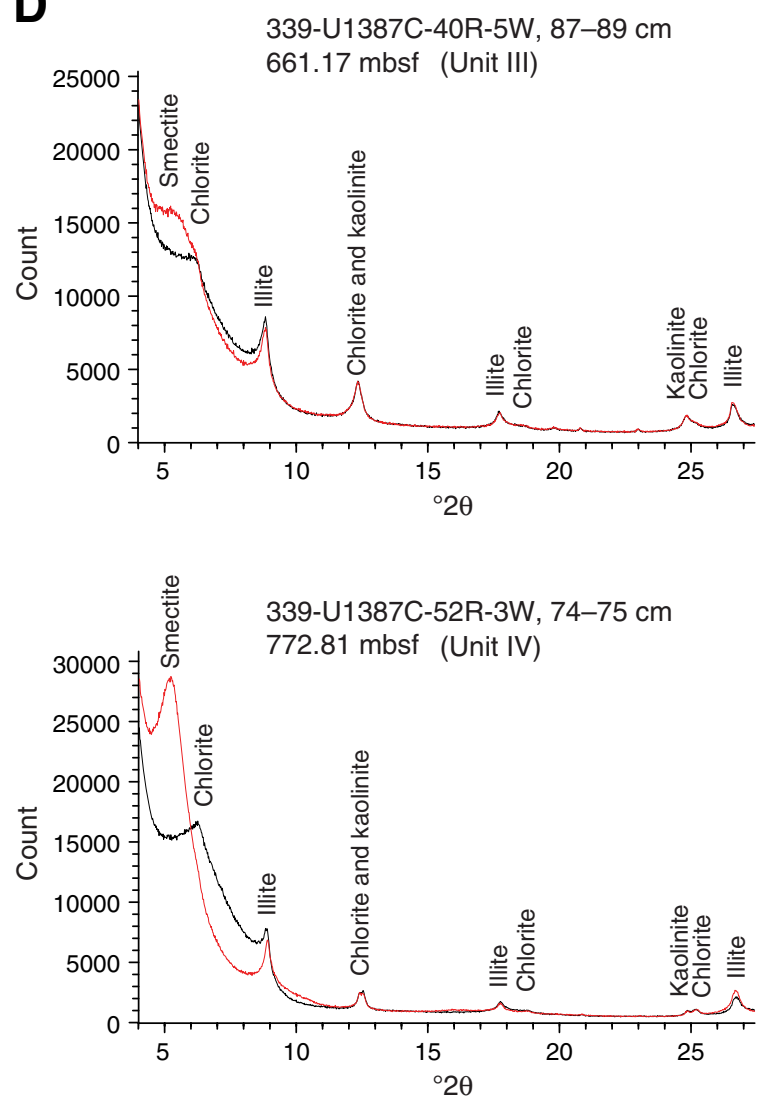

339-U1387C-44R-1W, 37-38 cm 693.27 mbsf (Unit III)
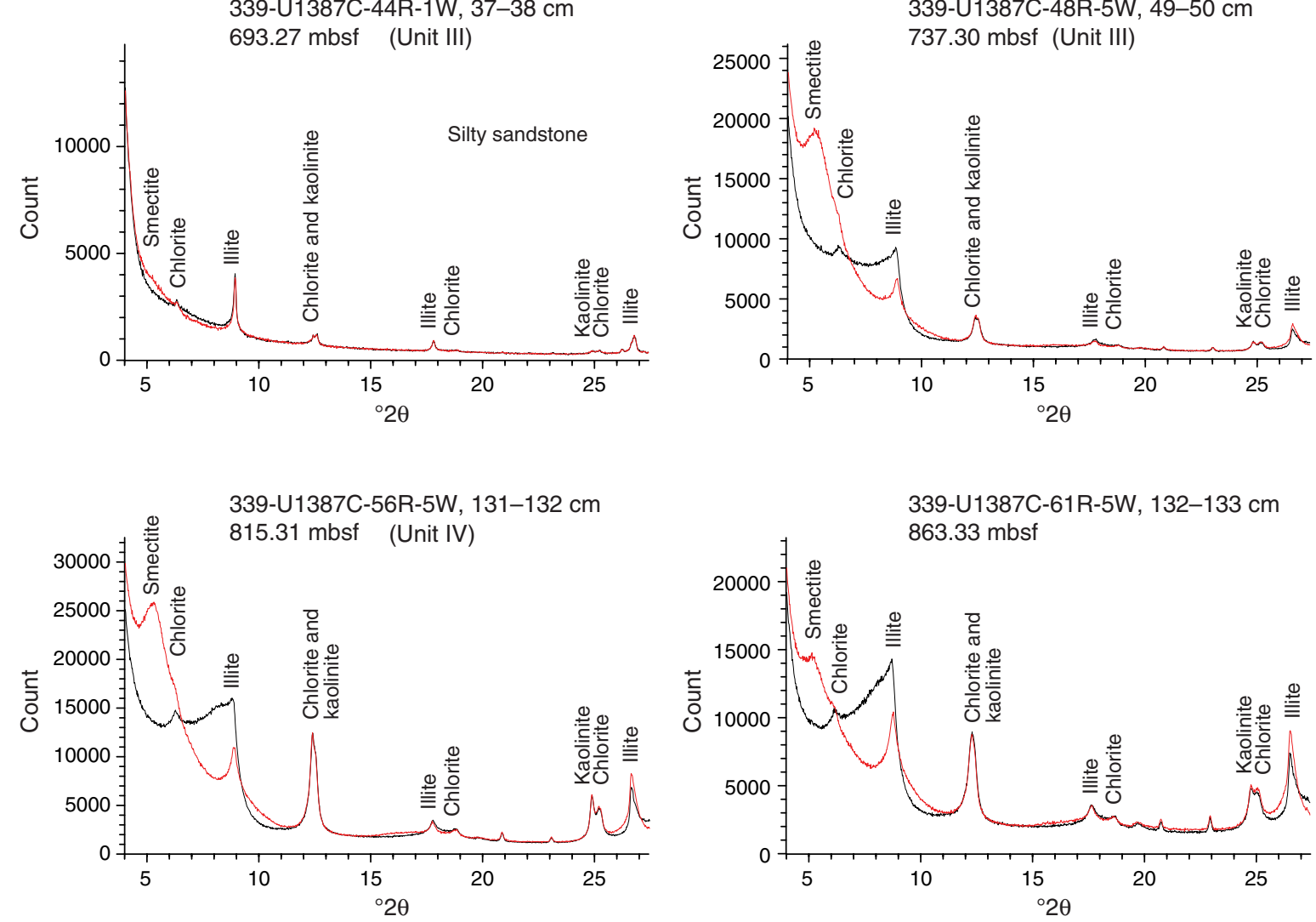
Figure F21. Photograph of coral fragments from Unit II (Sample 339-U1387C-28R-4, $31 \mathrm{~cm}$ ).
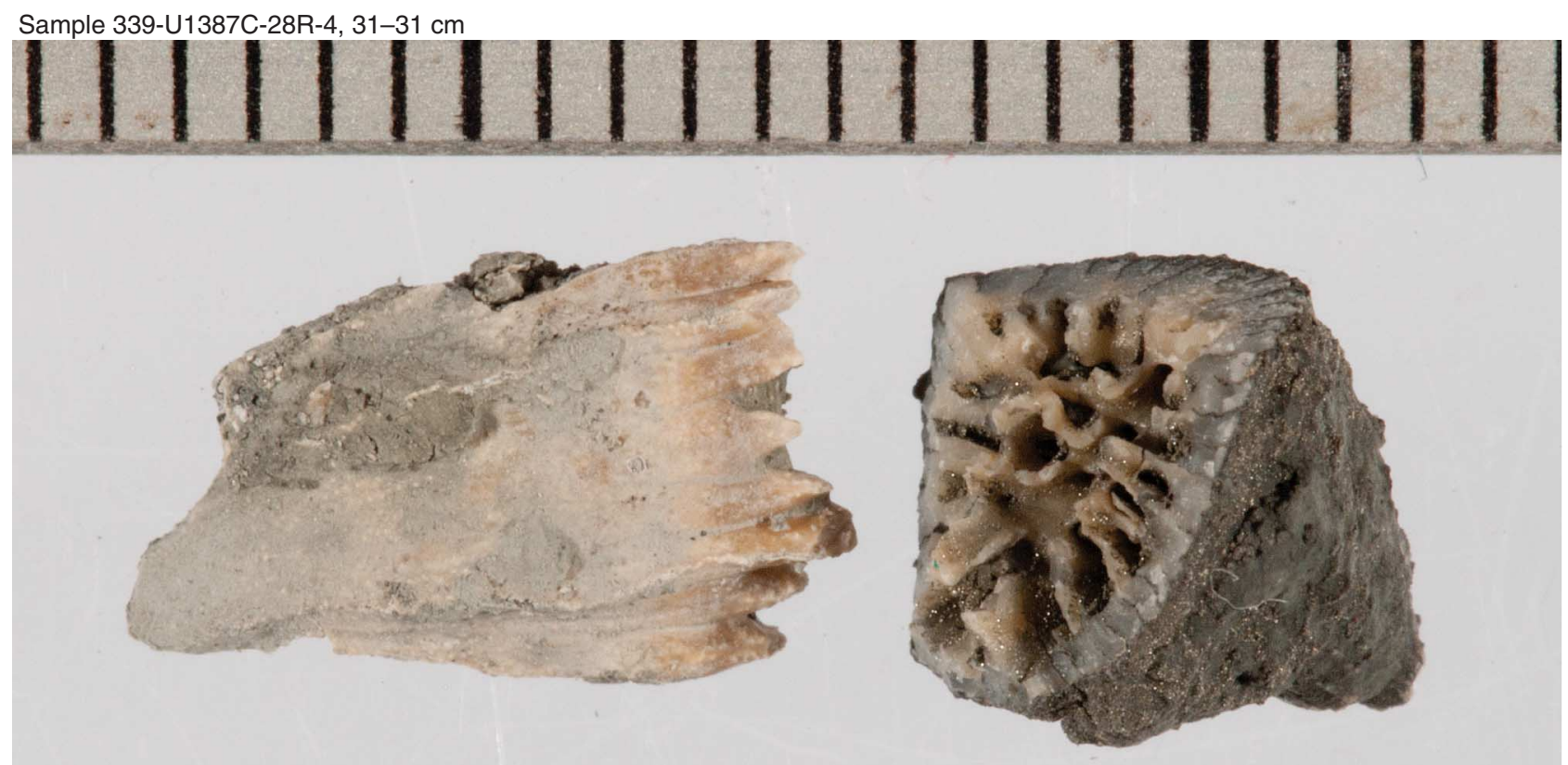
Figure F22. Core images of a very dark greenish gray shell-rich sand bed, interpreted as a debrite in Unit III (Sections 339-U1387C-39R-1A through 39R-2A). A, B. Coarse shell-rich sand, containing mud intra-clasts. Orientations of shell fragments show flow directions.

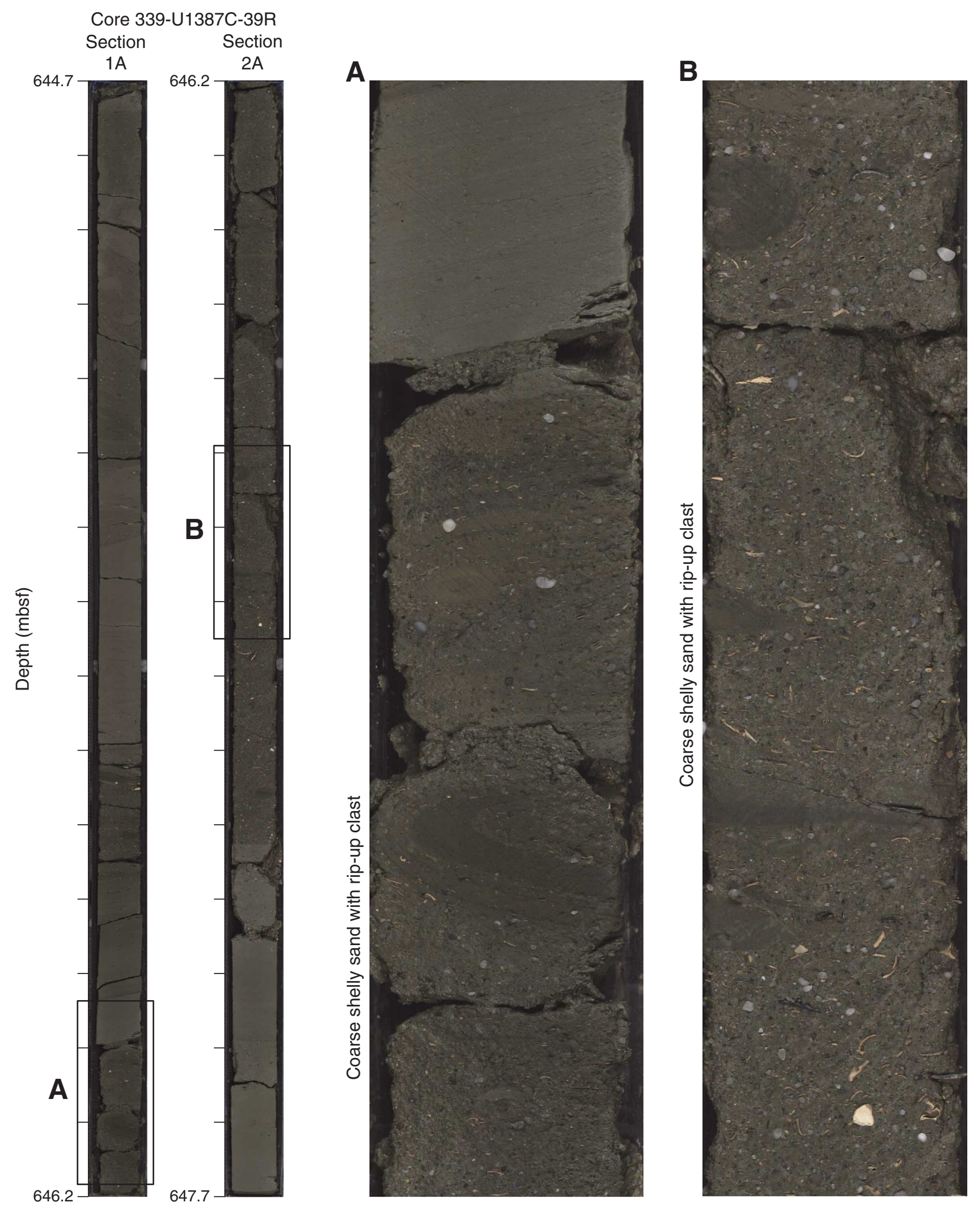


Figure F23. Core images of a thin bed of black carbonaceous sediment (Section 339-U1387C-42R-5A).

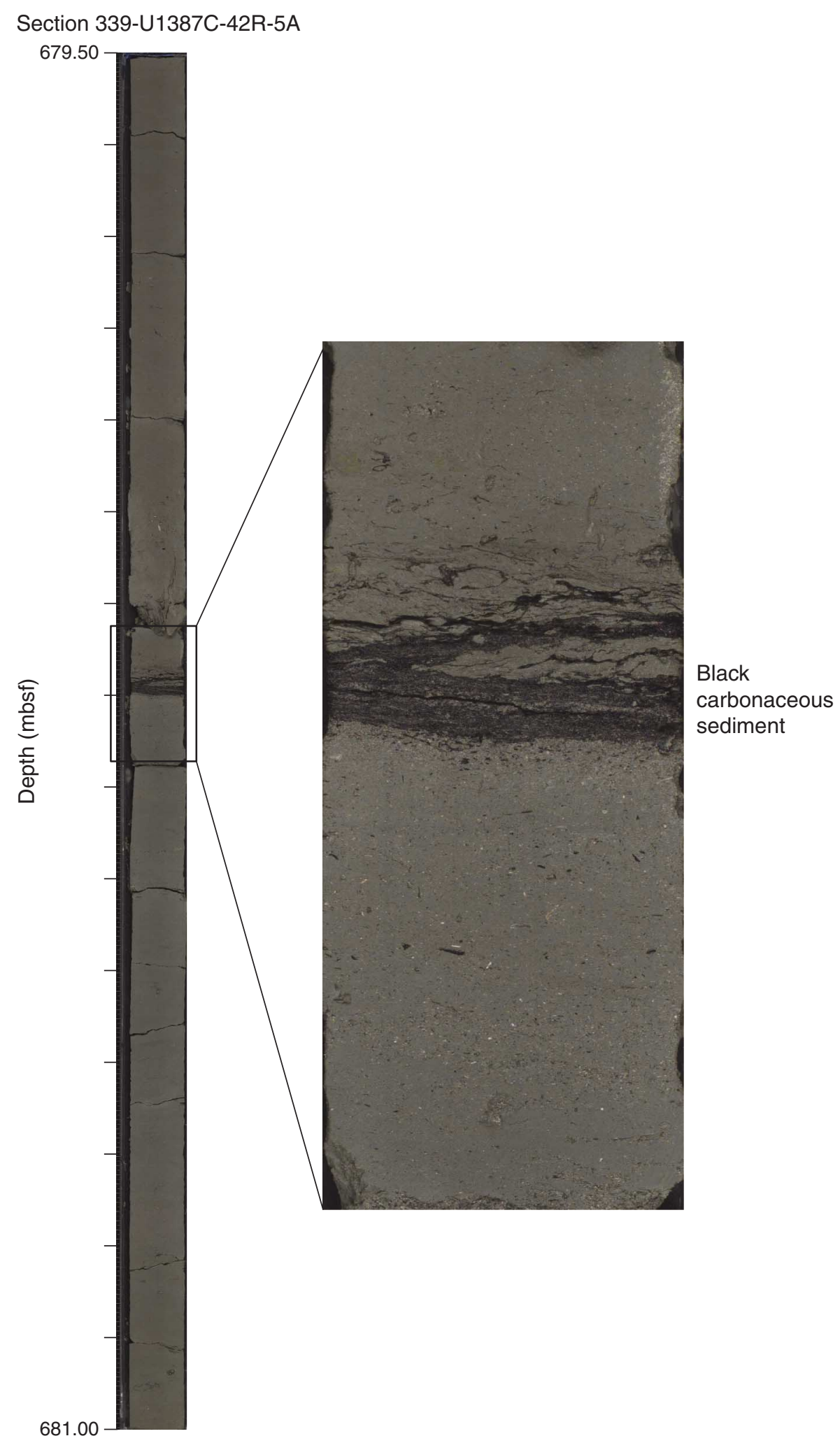


Figure F24. Plots comparing the number of silty mud and sandy beds and number of beds interpreted as sandy contourites, sandy turbidites, contourite-turbidite mixtures, contorted beds (slumps), sandstone, and dolostone.

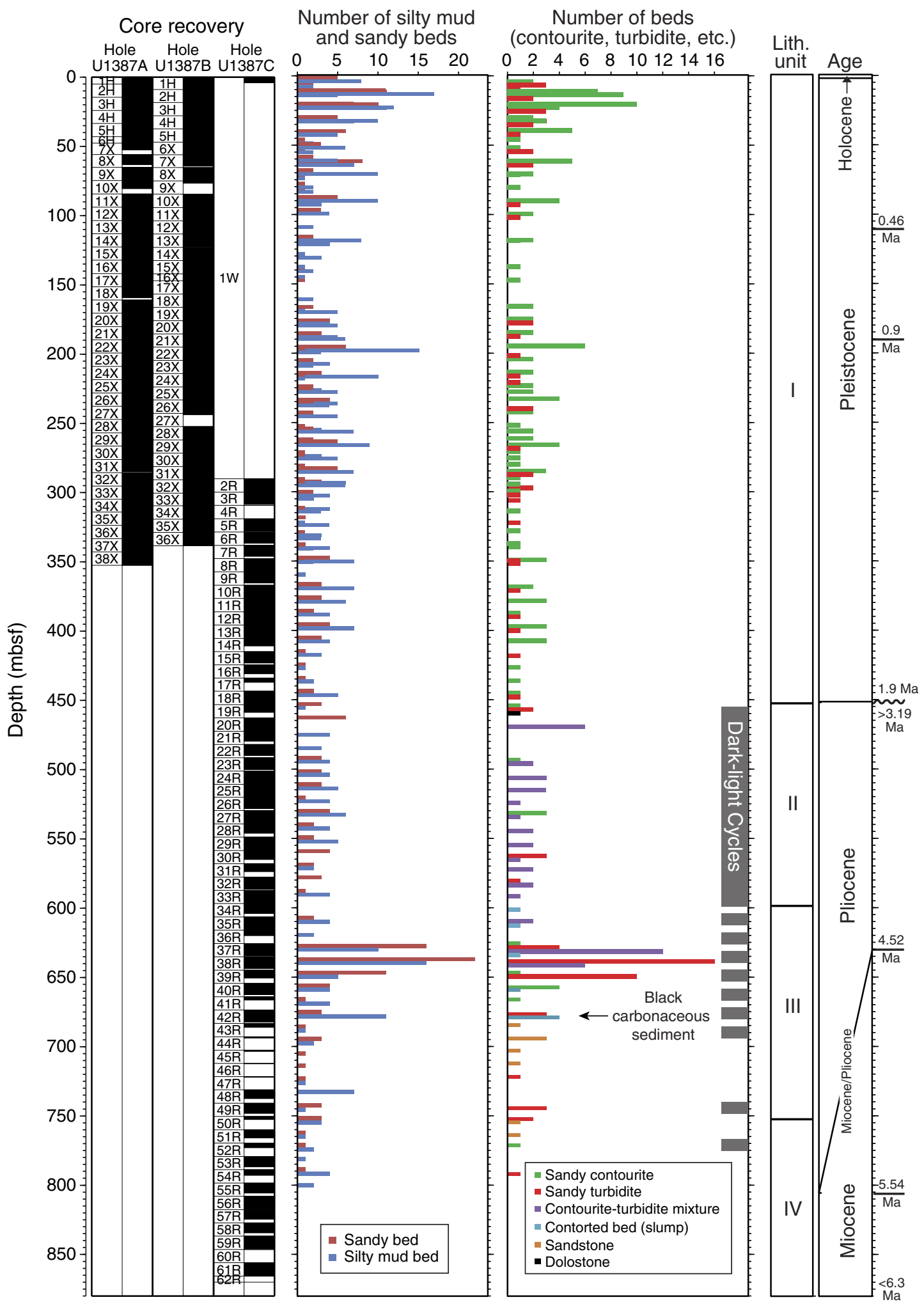


Figure F25. Biostratigraphic events vs. depth, Site U1387. Events are plotted at their mean depth (Table T5).

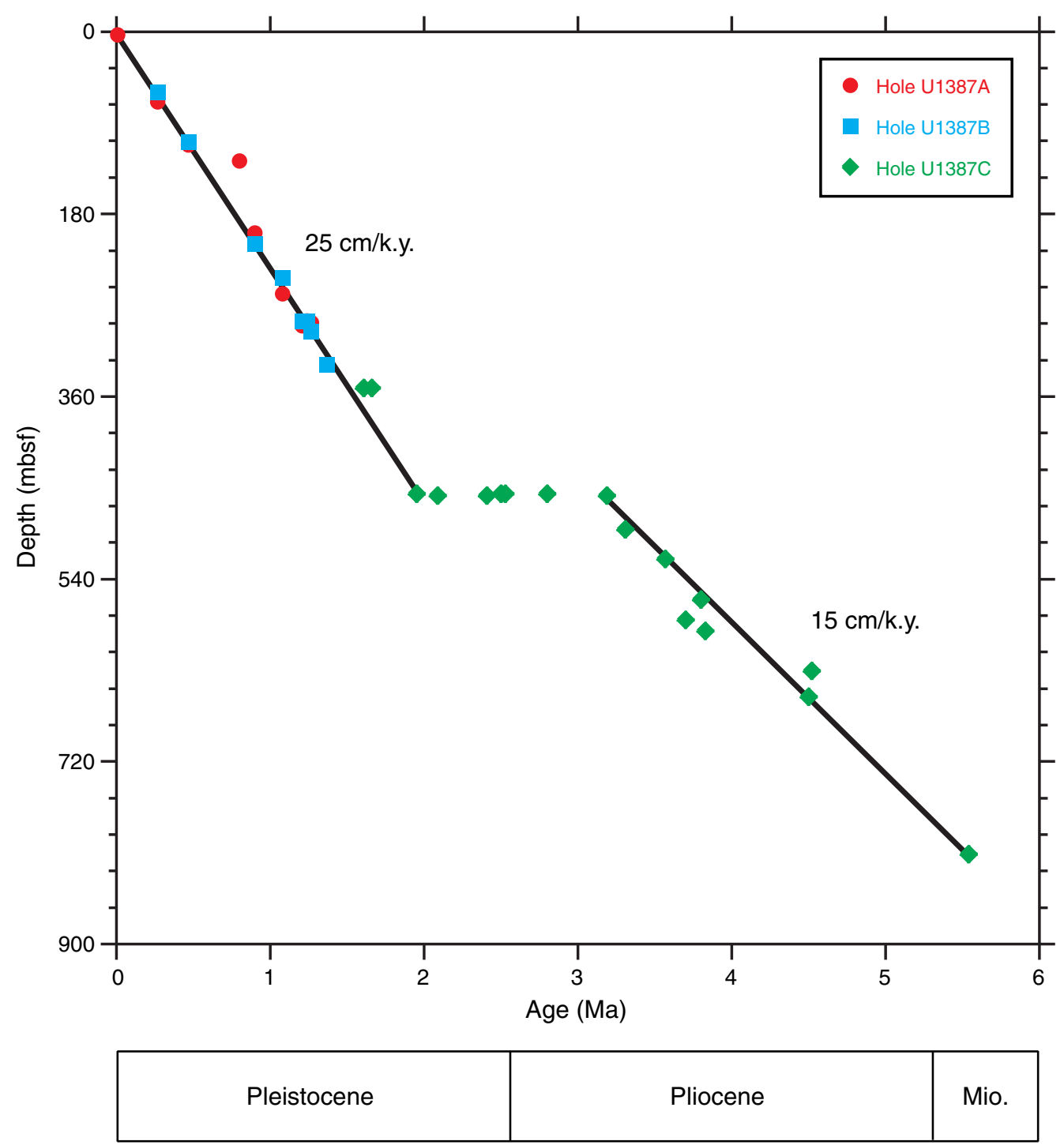


Figure F26. Preliminary pollen results from the analysis of 13 samples from Site U1387. Mediterranean forest is mainly deciduous and evergreen Quercus and Olea. TPS = total pollen and spores. Preservation: $\mathrm{G}=$ good, $\mathrm{M}=$ moderate, $\mathrm{P}=$ poor.

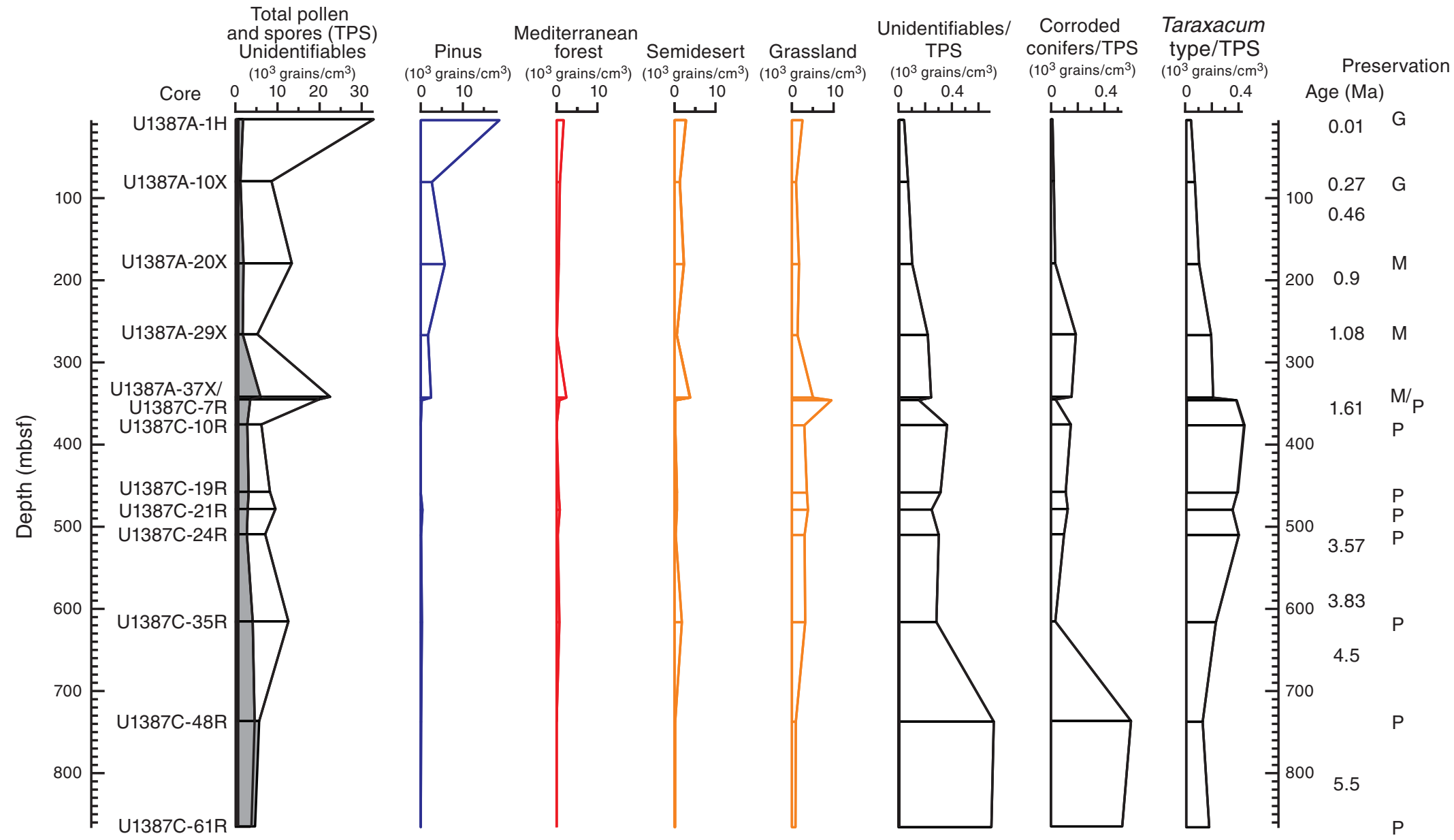


Figure F27. Paleomagnetism after $20 \mathrm{mT}$ AF demagnetization, Site U1387. Blue triangles = discrete sample locations. Yellow circles $=$ component inclinations of discrete samples with maximum angular deviation less than $\sim 15^{\circ}$. In the Chron columns, black $=$ normal polarity, white $=$ reversed polarity, and gray $=$ zones without a clear magnetostratigraphic interpretation. In Inclination columns, blue dashed lines = expected geocentric axial dipole inclinations at the site latitude during reversed (left) and normal (right) polarities. In Declination columns, light blue circles $=$ original declinations and dark blue squares $=$ FlexIt tool-corrected declinations. In Susceptibility columns, gray lines represent SHMSL susceptibility plus $25 \times 10^{-5}$ volume SI to better show the comparison with WRMSL susceptibility (black lines). (Figure shown on next four pages.) 
Figure F27 (continued). A. Hole U1387A. (Caption shown on previous page.) (Continued on next page.)

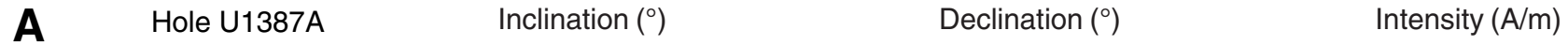

Susceptibility $\left(10^{-5} \mathrm{SI}\right)$

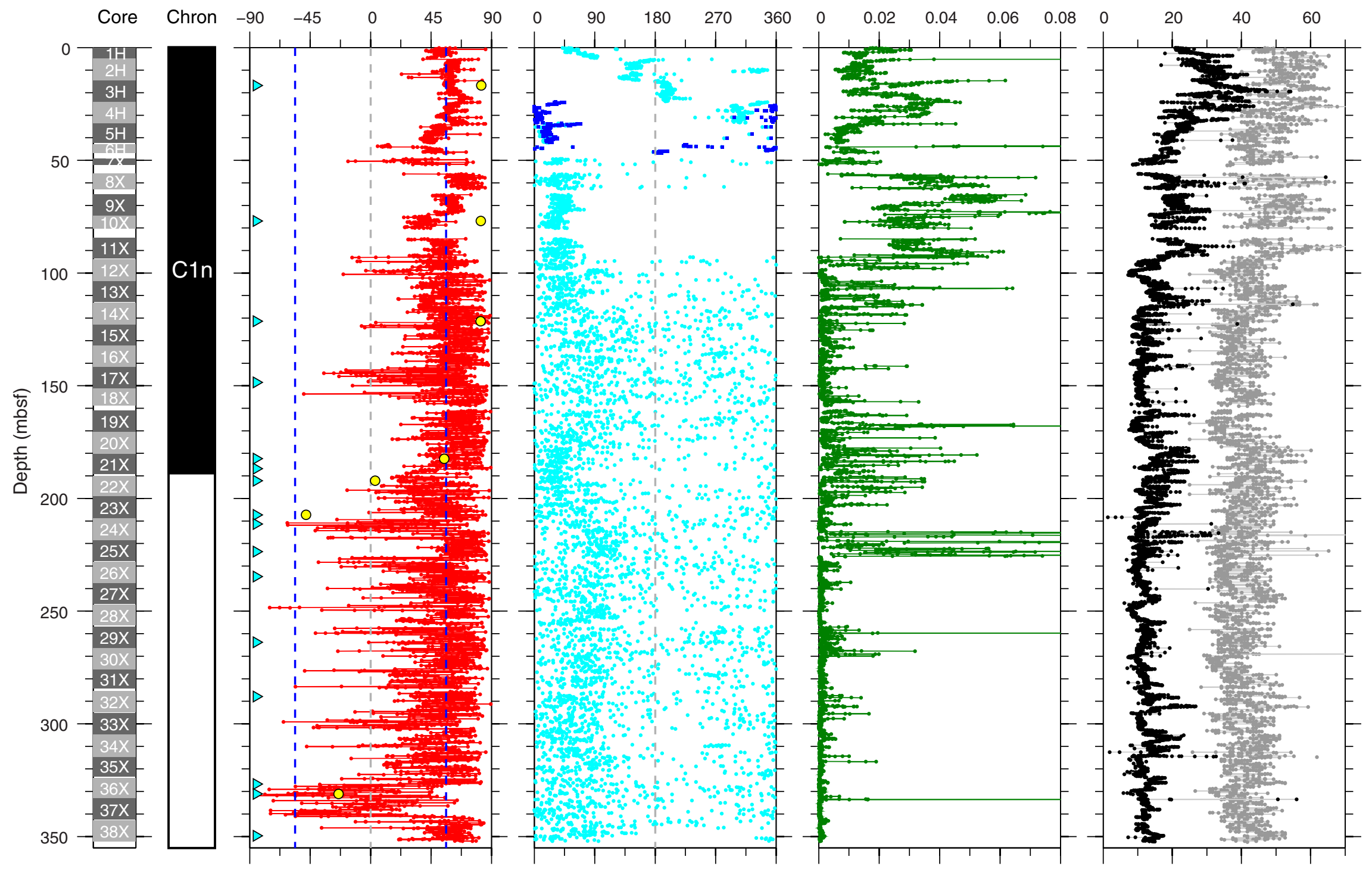


Figure F27 (continued). B. Hole U1387B. (Continued on next page.)

$$
\text { B Hole U1387B Inclination }\left(^{\circ}\right) \quad \text { Declination }\left({ }^{\circ}\right)
$$

Intensity $(\mathrm{A} / \mathrm{m})$

Susceptibility $\left(10^{-5} \mathrm{SI}\right)$

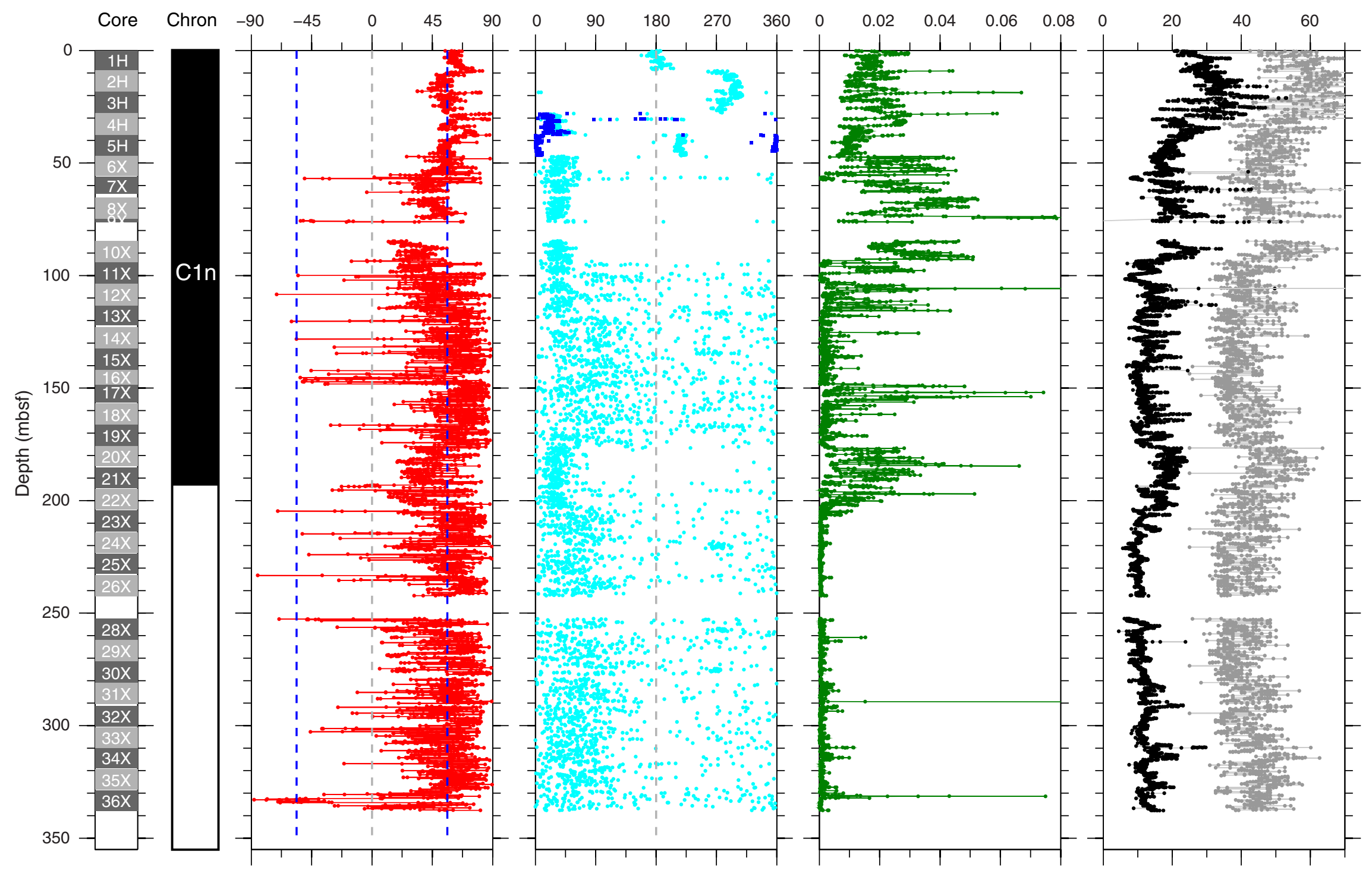


Figure F27 (continued). C. Hole U1387C, Cores 2R through 30R. (Continued on next page.)

C Hole U1387C

Inclination $\left({ }^{\circ}\right)$

Declination $\left(^{\circ}\right)$

Intensity $(\mathrm{A} / \mathrm{m})$

Susceptibility $\left(10^{-5} \mathrm{SI}\right)$
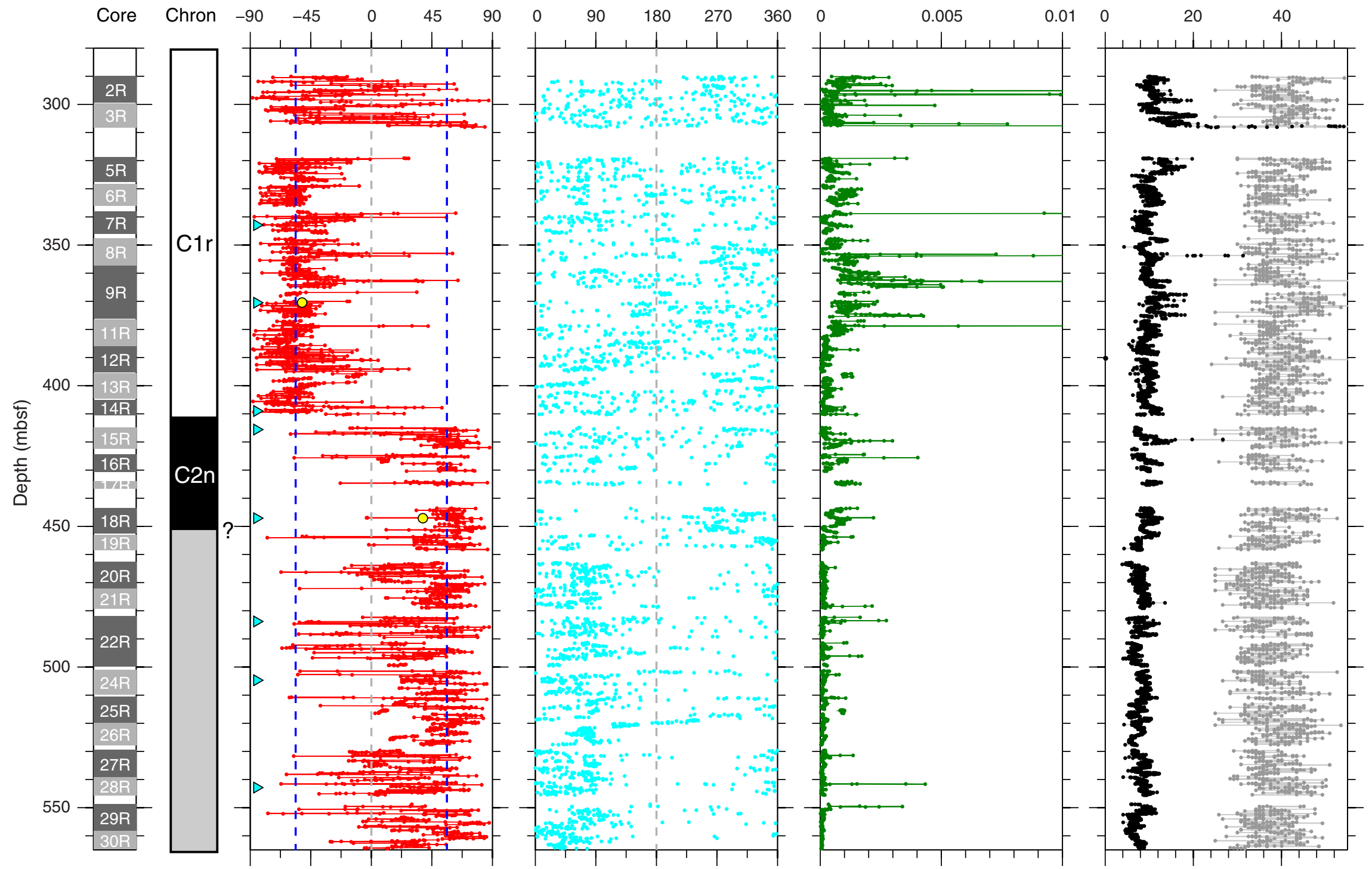
Figure F27 (continued). D. Hole U1387C, Cores 31R through 61R.

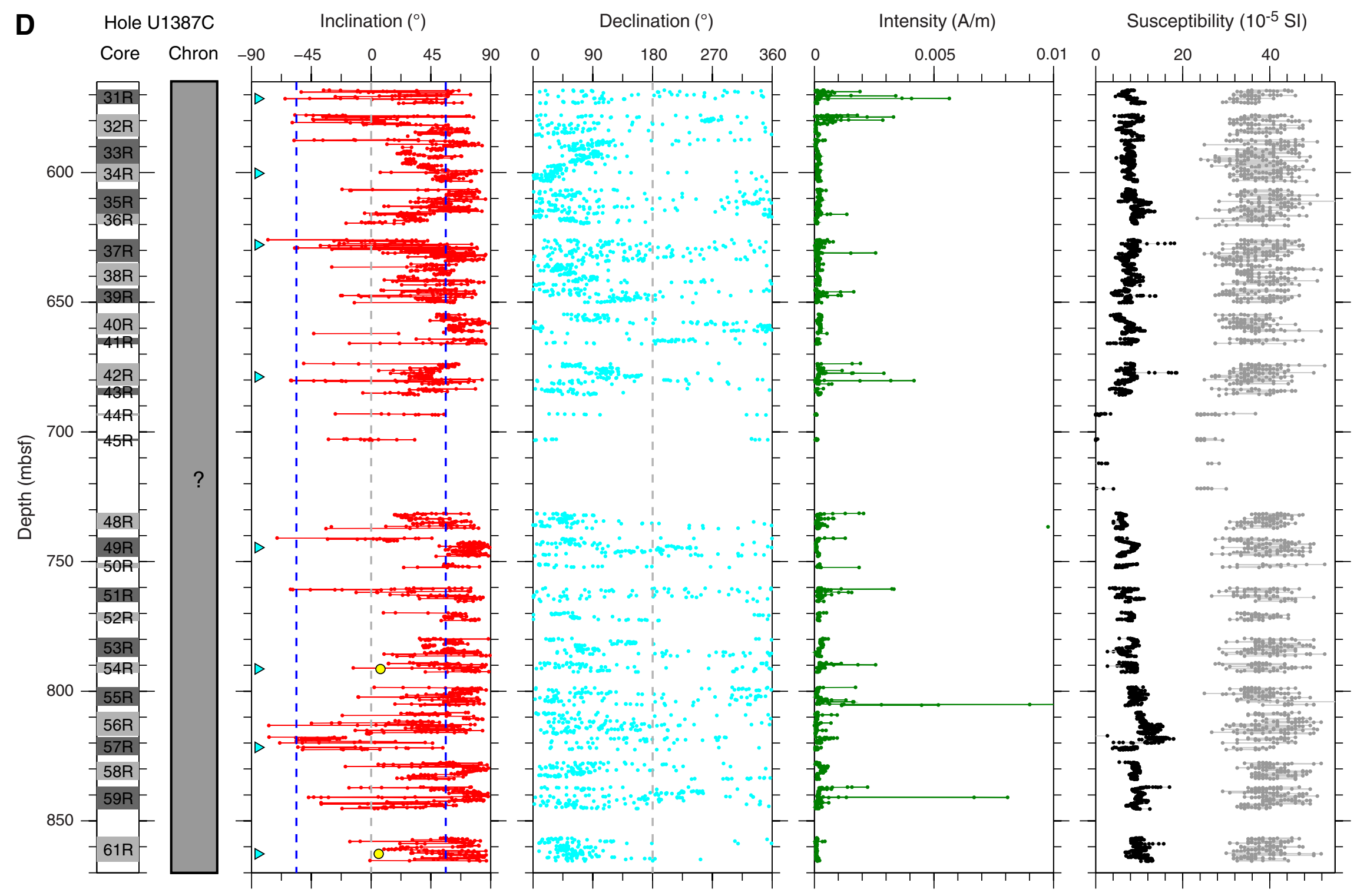


Figure F28. AF demagnetization results for eight discrete samples, Site U1387. Right plots show the vector endpoints of paleomagnetic directions measured after each demagnetization treatment on an orthogonal projection (Zijderveld) plot. Squares $=$ horizontal projections, circles $=$ vertical projections. Left plots show intensity variation with progressive demagnetization. Orthogonal projection plots illustrate the removal of a steep drilling overprint by 15-20 mT peak field AF demagnetization and a significant amount of ARM acquisition during high-peak field ( $>55 \mathrm{mT}$ ) AF demagnetization, with the remaining magnetization providing a well-resolved characteristic remanent magnetization.
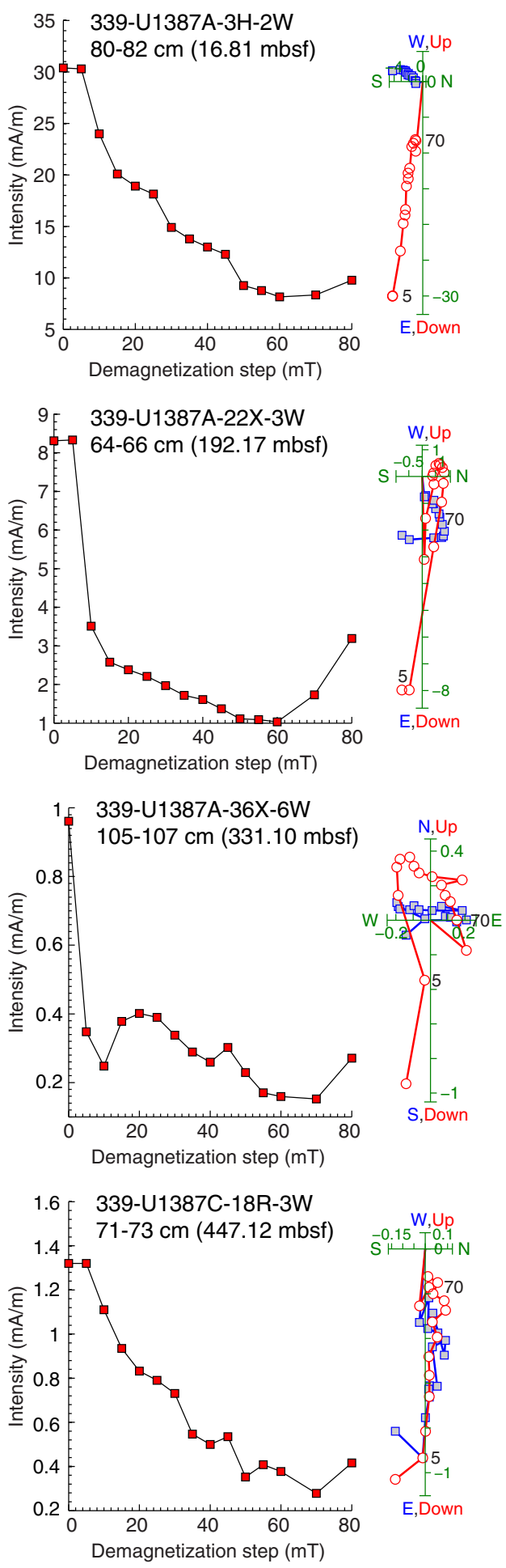
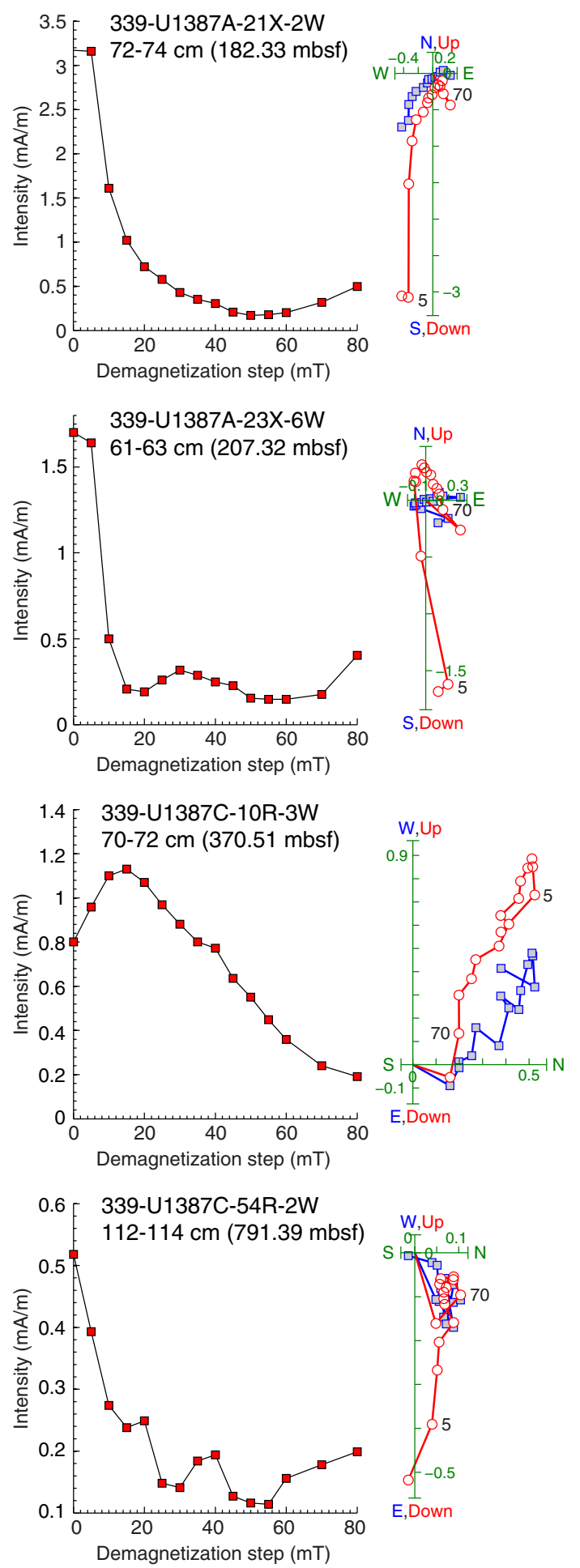
Figure F29. Plots of $P$-wave velocity (PWV) measured on the Whole-Round Multisensor Logger (WRMSL; green lines) and Section-Half Measurement Gantry (discrete samples) set to automatic (solid circles) and manual (open circles) mode, wet bulk density measurements on discrete samples (red diamonds), gamma ray attenuation density measured on the WRMSL (black line), and magnetic susceptibility (MS) measured on the WRMSL (black line) and on split cores (light green circles). Note that records were cleaned for outliers and bad data at sections ends. $\mathrm{PP}=$ physical properties. A. Hole U1387A. (Continued on next page.)

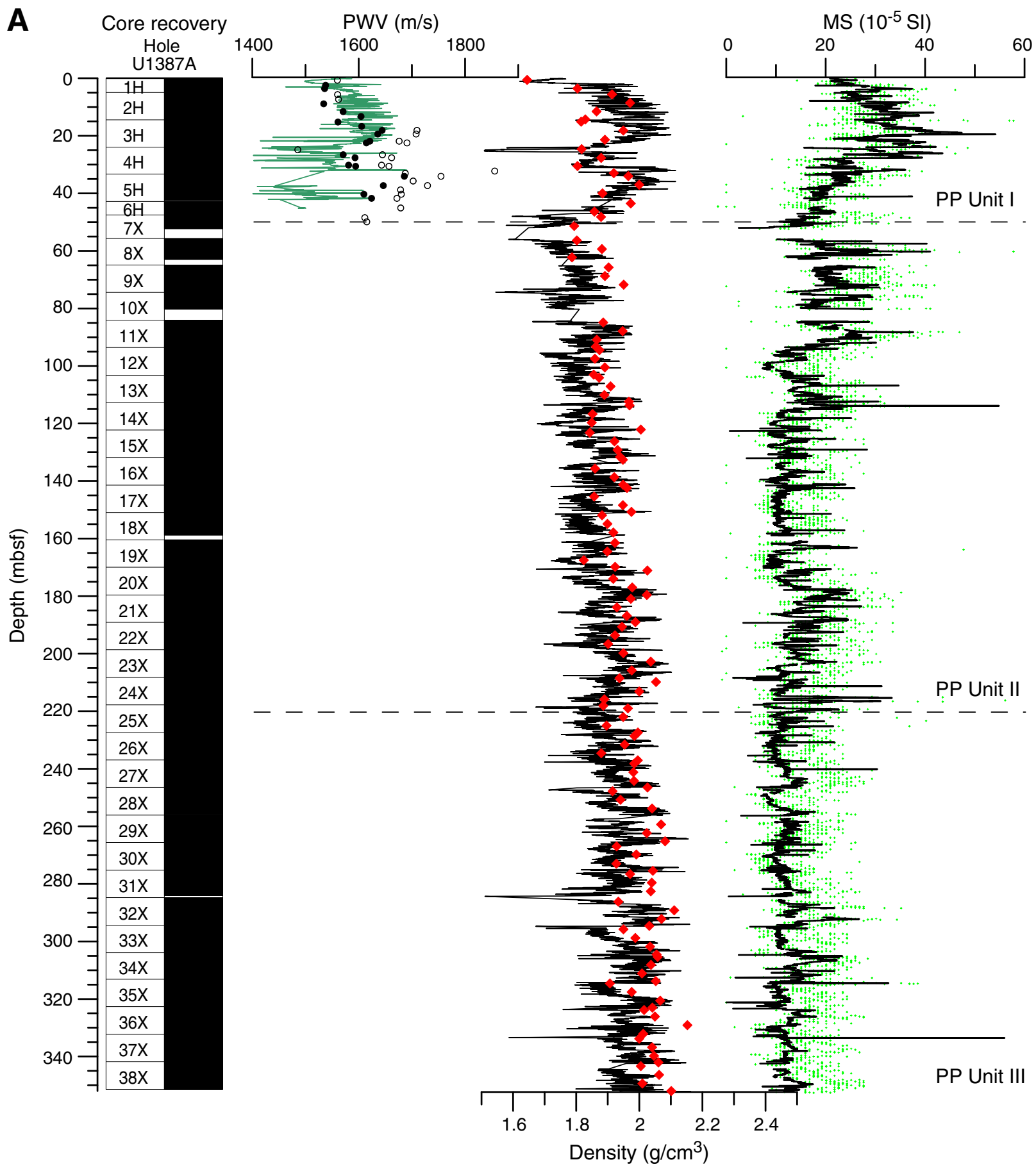


Figure F29 (continued). B. Hole U1387C.

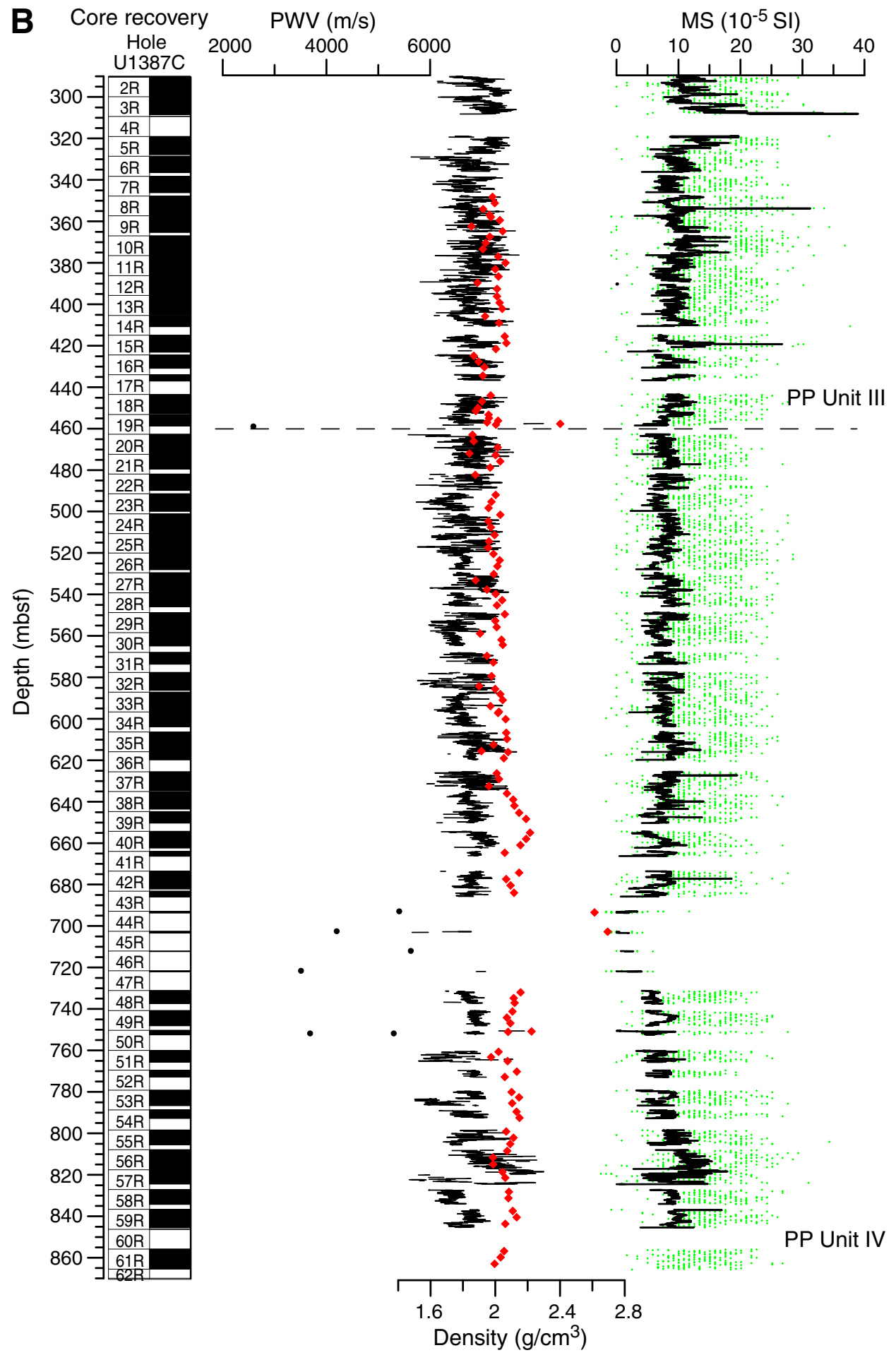


Figure F30. Plots of color reflectance $\left(\mathrm{L}^{*}\right.$ and $\left.\mathrm{a}^{*}\right)$ and natural gamma ray (NGR) measurements. Note that data were cleared for outliers and bad data at section ends. Reflectance data were smoothed with a 10-point running mean. $\mathrm{PP}=$ physical properties. A. Hole U1387A. (Continued on next page.)

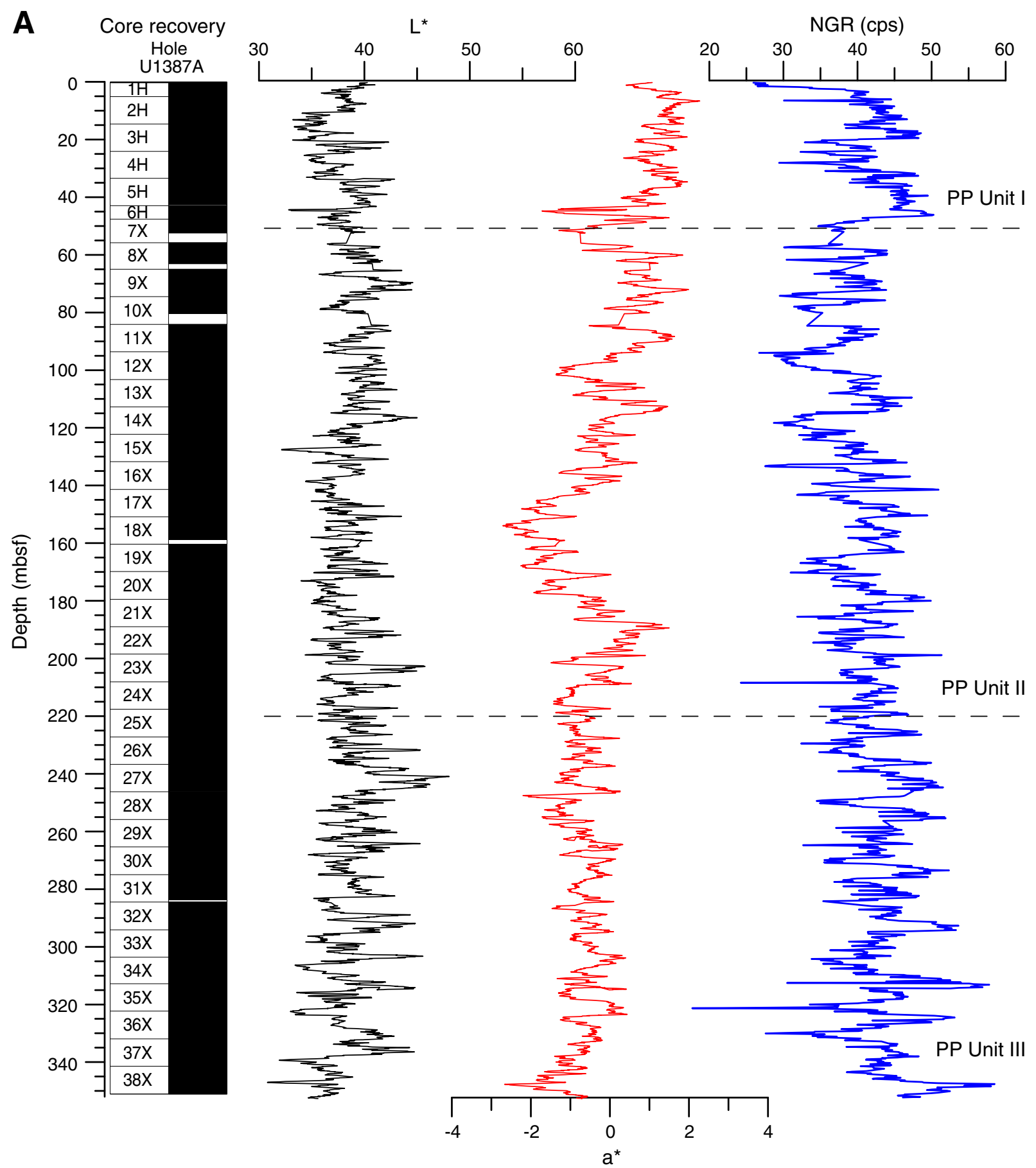


Figure F30 (continued). B. Hole U1387C.

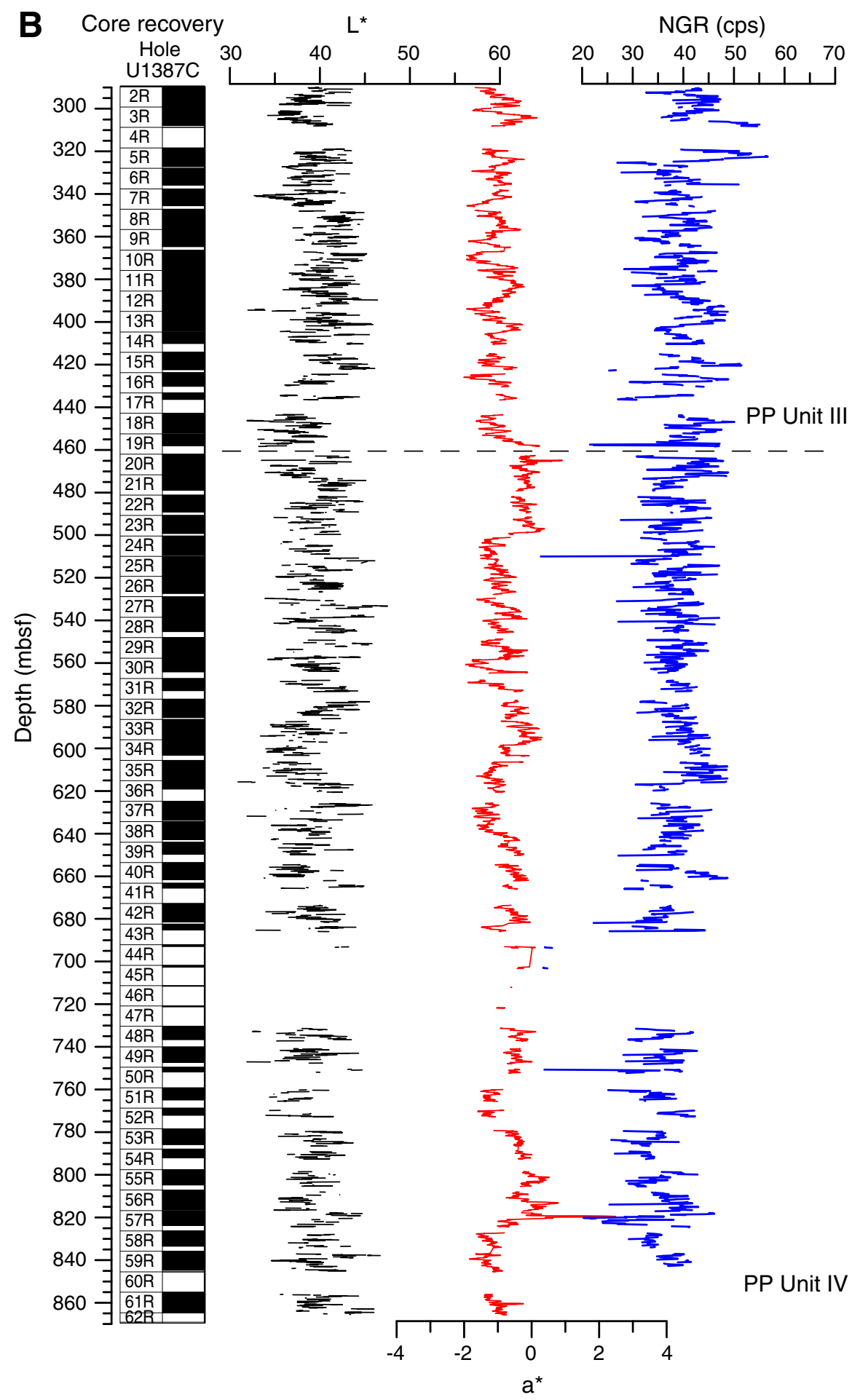


Figure F31. Plots of downhole distribution of discrete measurements of grain density, moisture content, and porosity. PP = physical properties. A. Hole U1387A. (Continued on next page.)

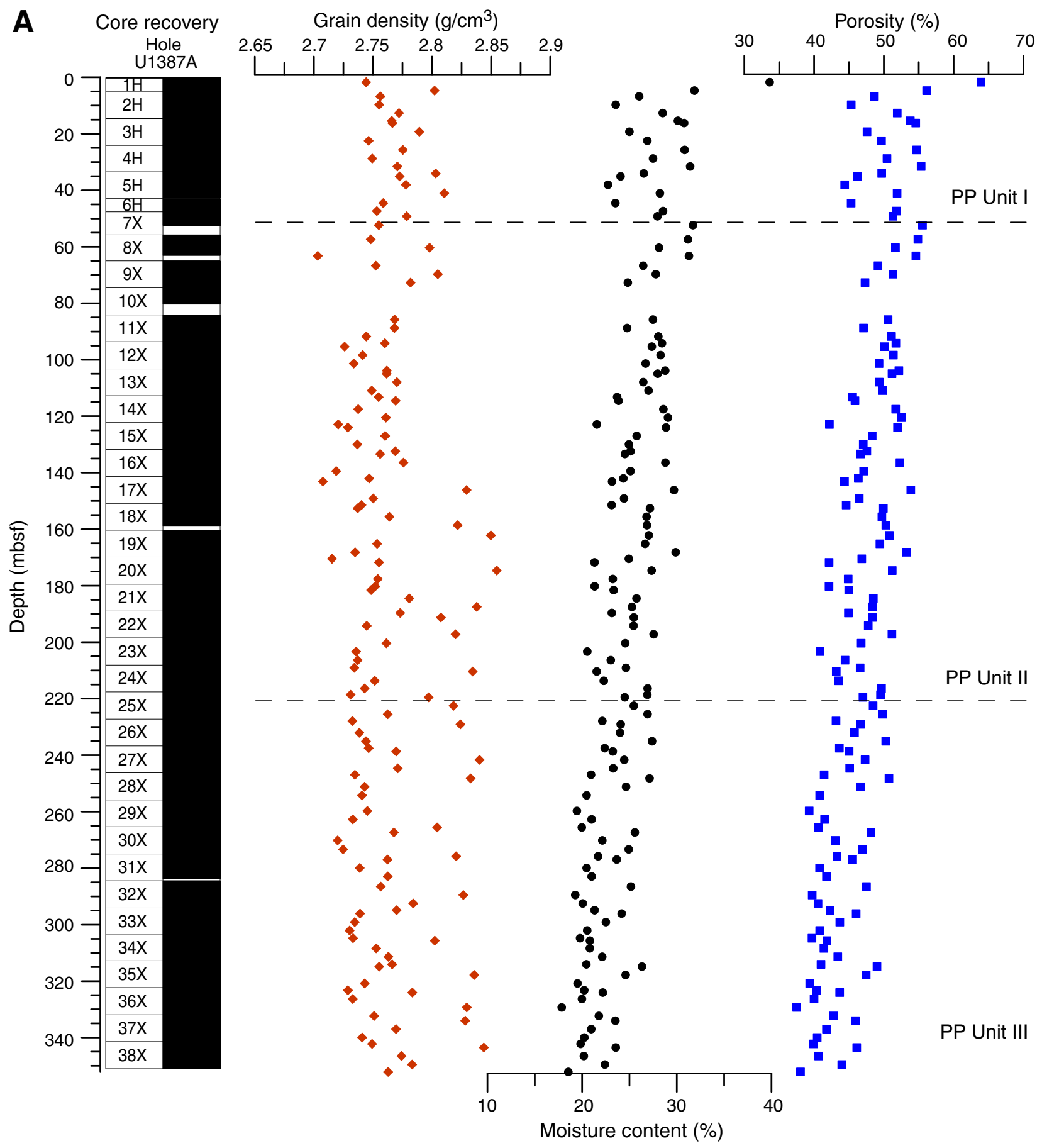


Figure F31 (continued). B. Hole U1387C.

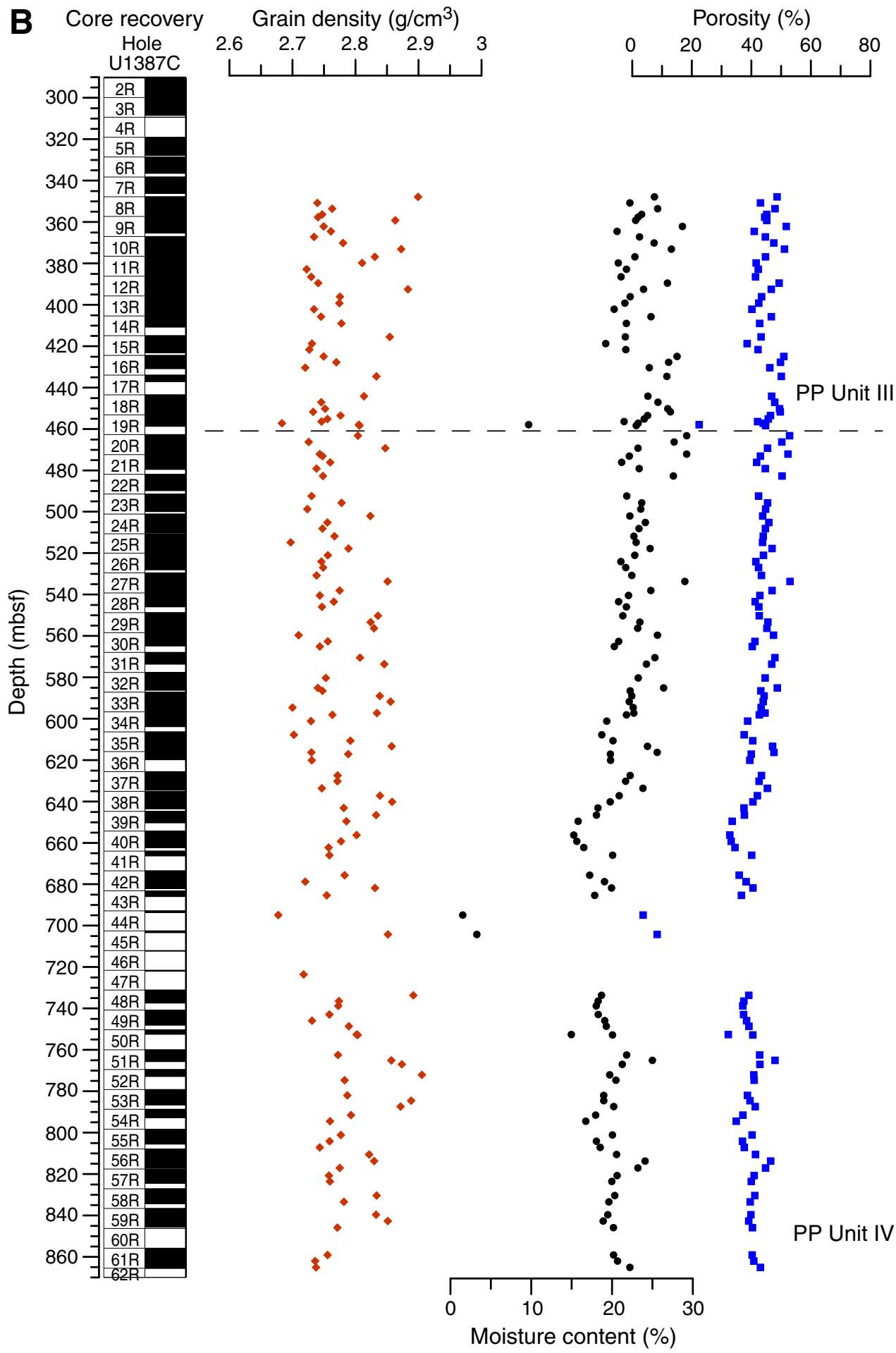


Figure F32. Plot of headspace gas analyses for volatile hydrocarbons, Holes U1387A and U1387C.

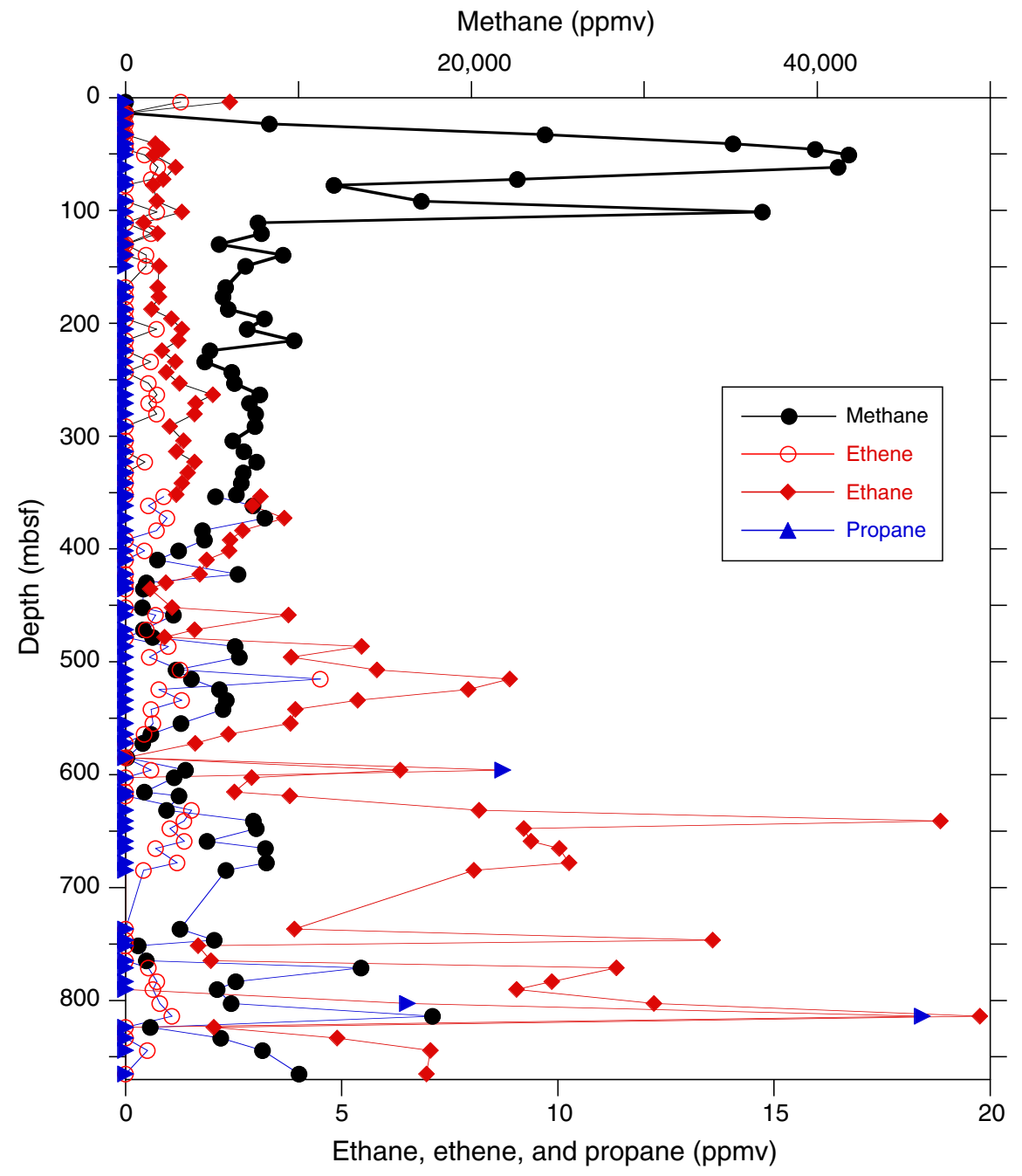


Figure F33. Plot of calcium carbonate, Holes U1387A (solid circles) and U1387C (open circles).

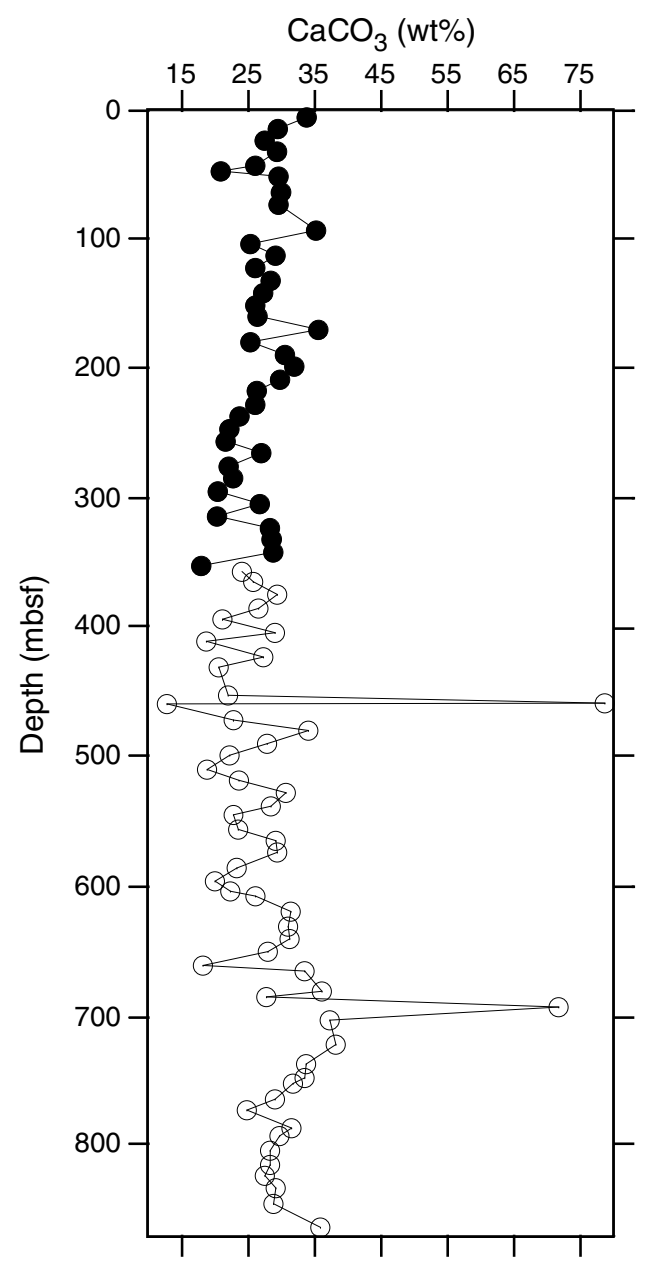


Figure F34. A-C. Plots of calculated total organic carbon (TOC), total nitrogen (TN), and C/N ratio, Holes U1387A (solid circles) and U1387C (open circles).

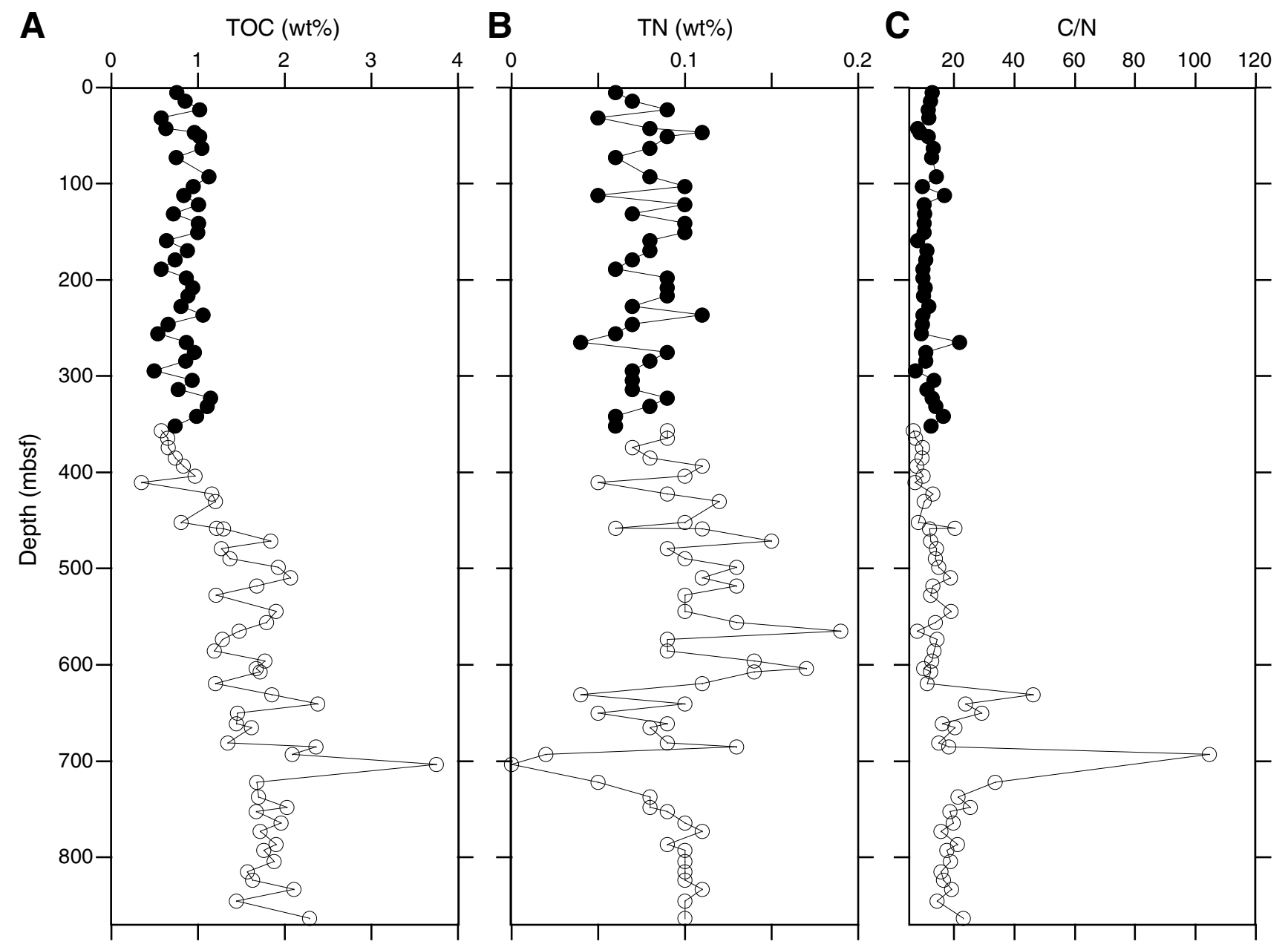


Figure F35. Plots of interstitial water (A, B) sulfate, alkalinity, ammonium, and (C) methane, Holes U1387A (red) and U1386A (blue).

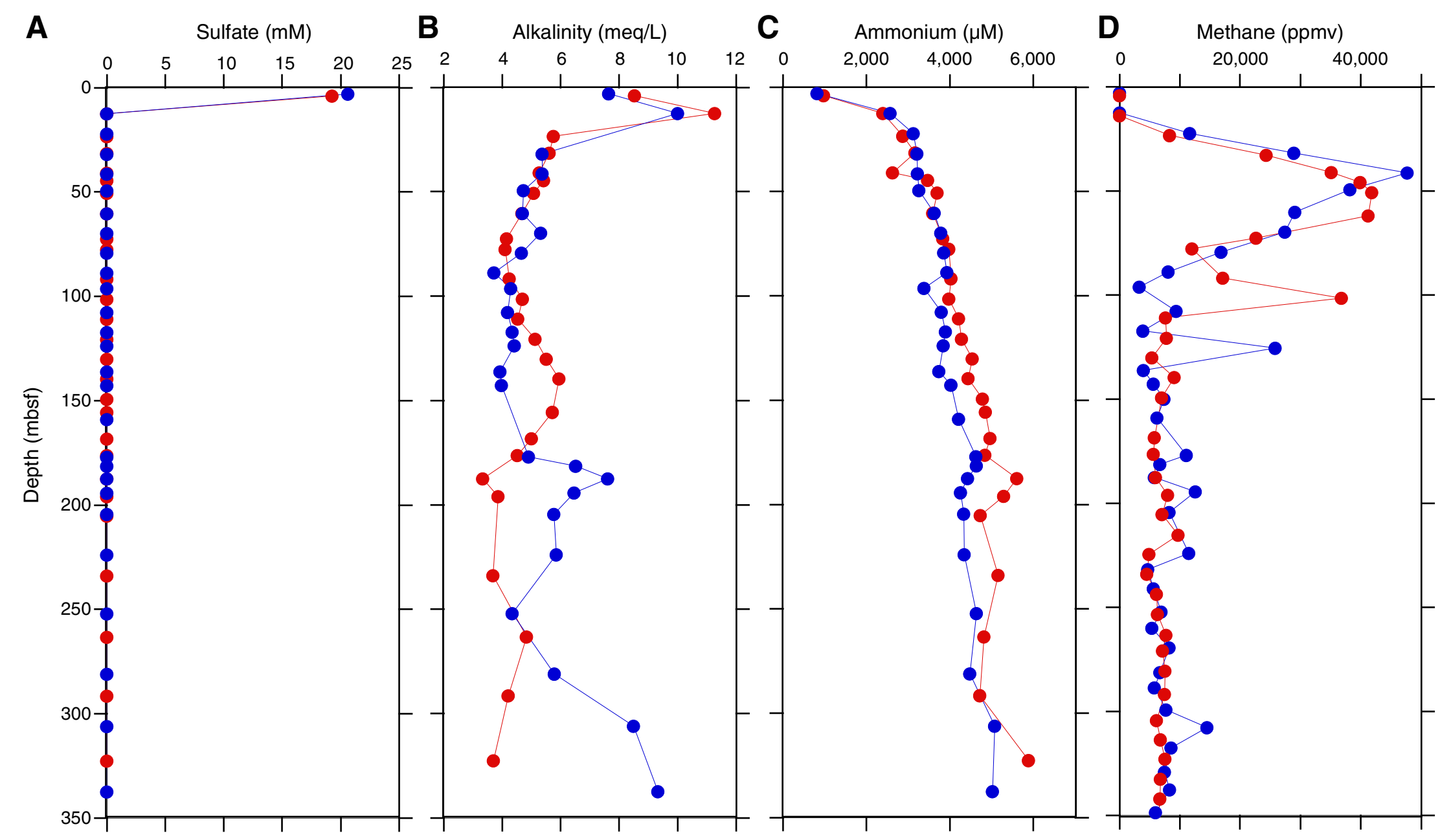


Figure F36. A-D. Plots of interstitial water calcium, magnesium, potassium, and sodium, Holes U1387A (red) and U1386A (blue).

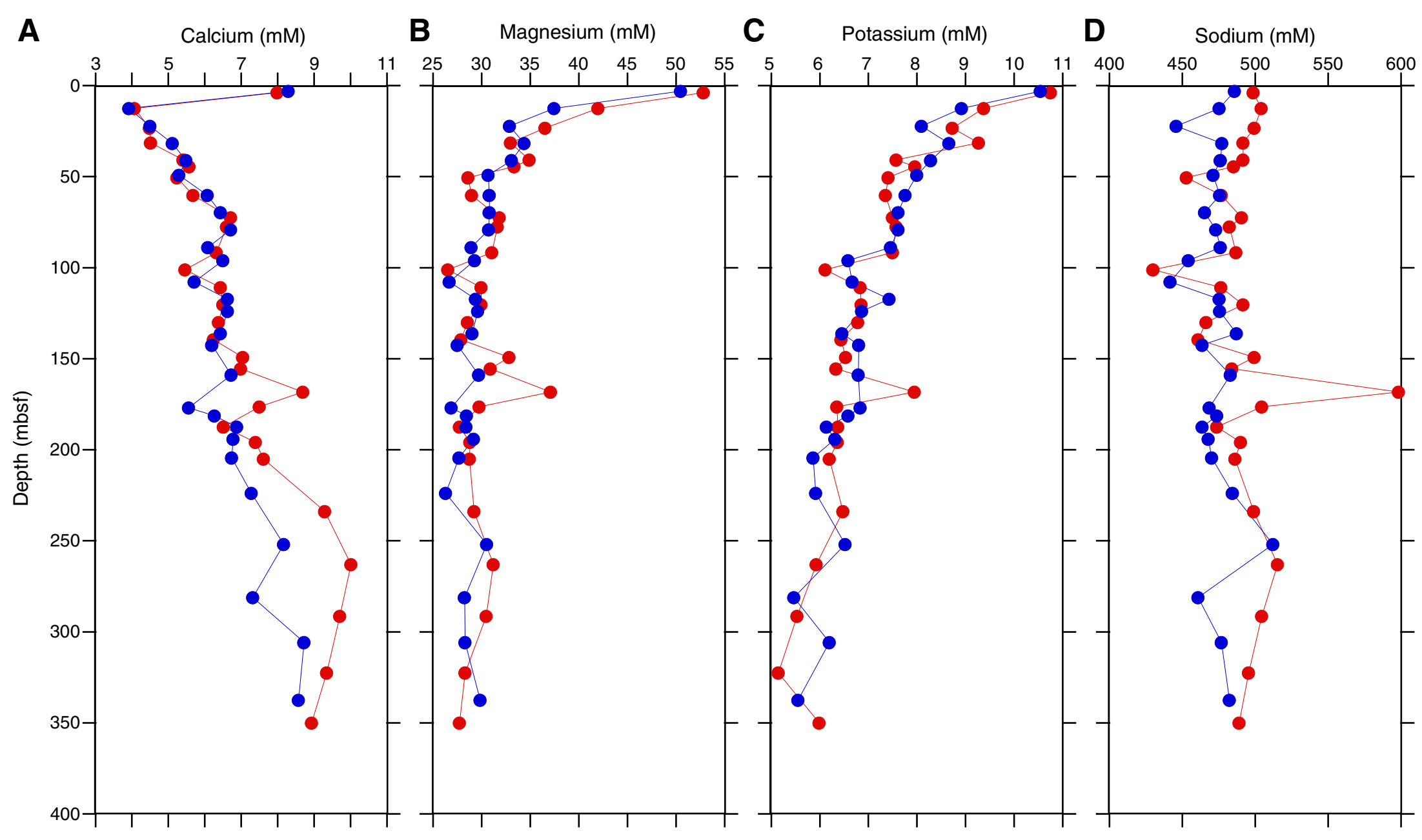


Figure F37. Plots of interstitial water chloride and $\mathrm{Na}^{+} / \mathrm{Cl}^{-}$ratio, Holes U1387A (red) and U1386A (blue).

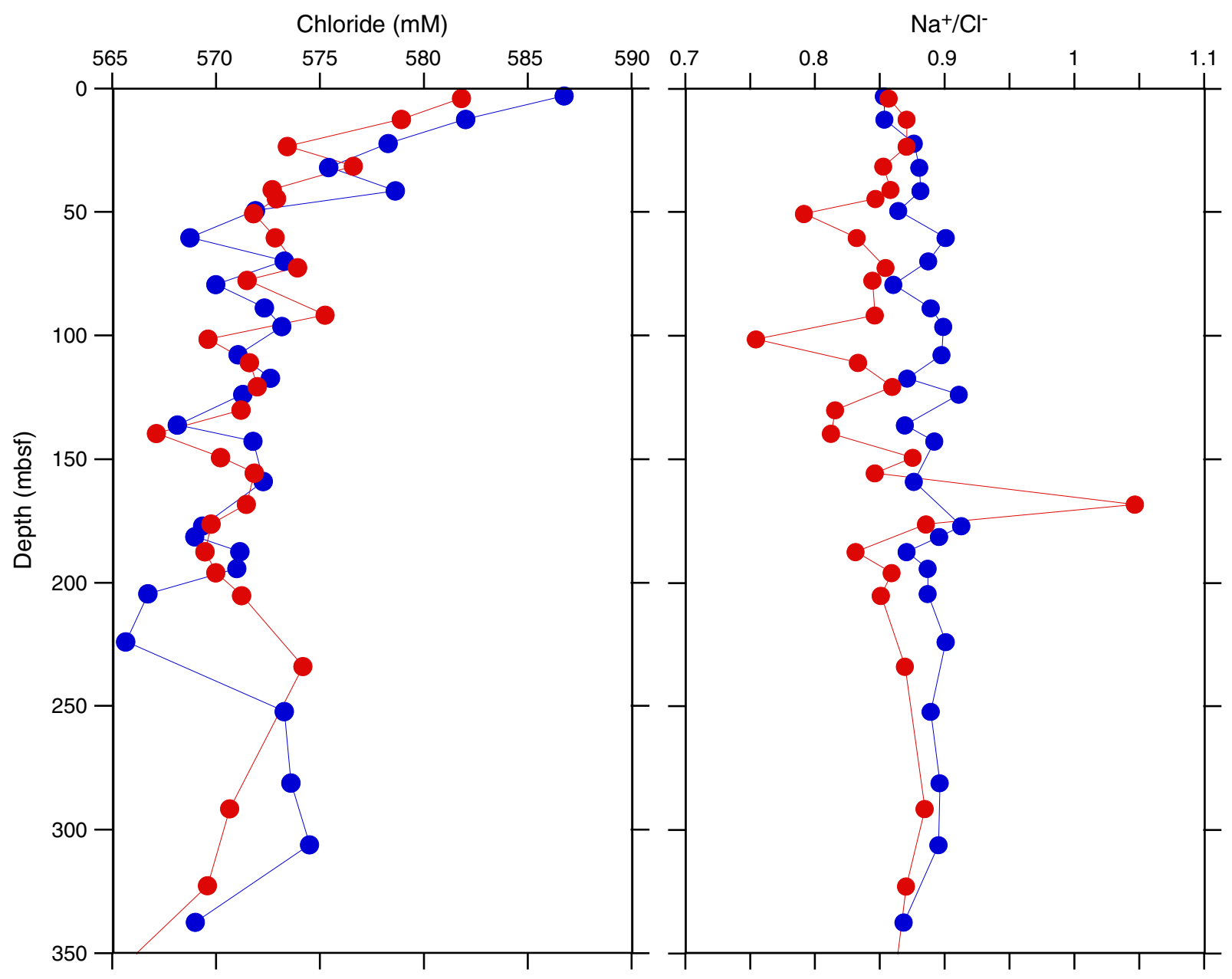




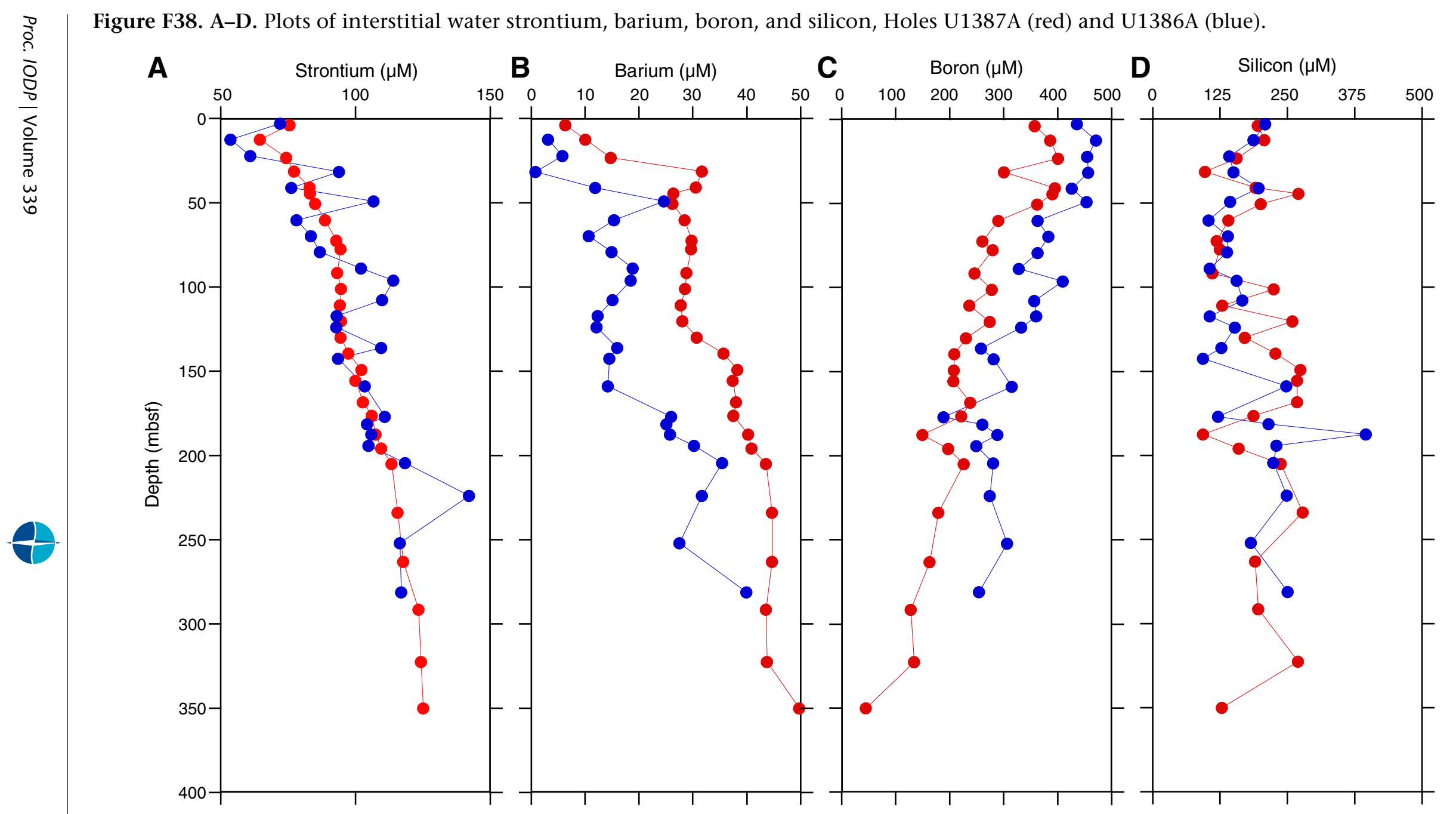


Figure F39. Plot of interstitial water strontium (black) and barium (blue) vs. calcium, Hole U1387A. Strontium and barium were measured by inductively coupled plasma-atomic emission spectrometry.

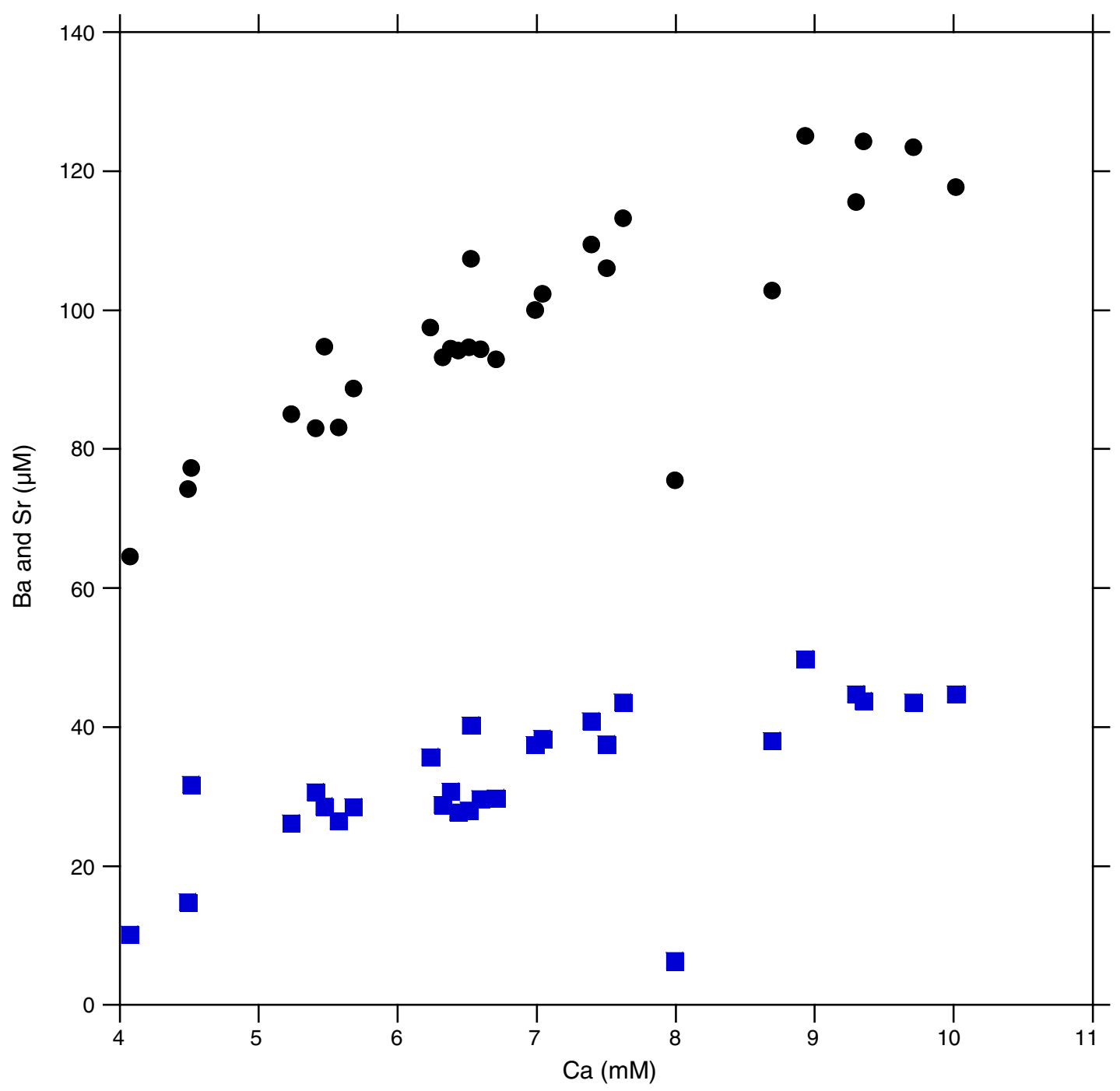


Figure F40. Logging operations summary diagram, Site U1387. VSP = vertical seismic profile, FMS = Formation MicroScanner.

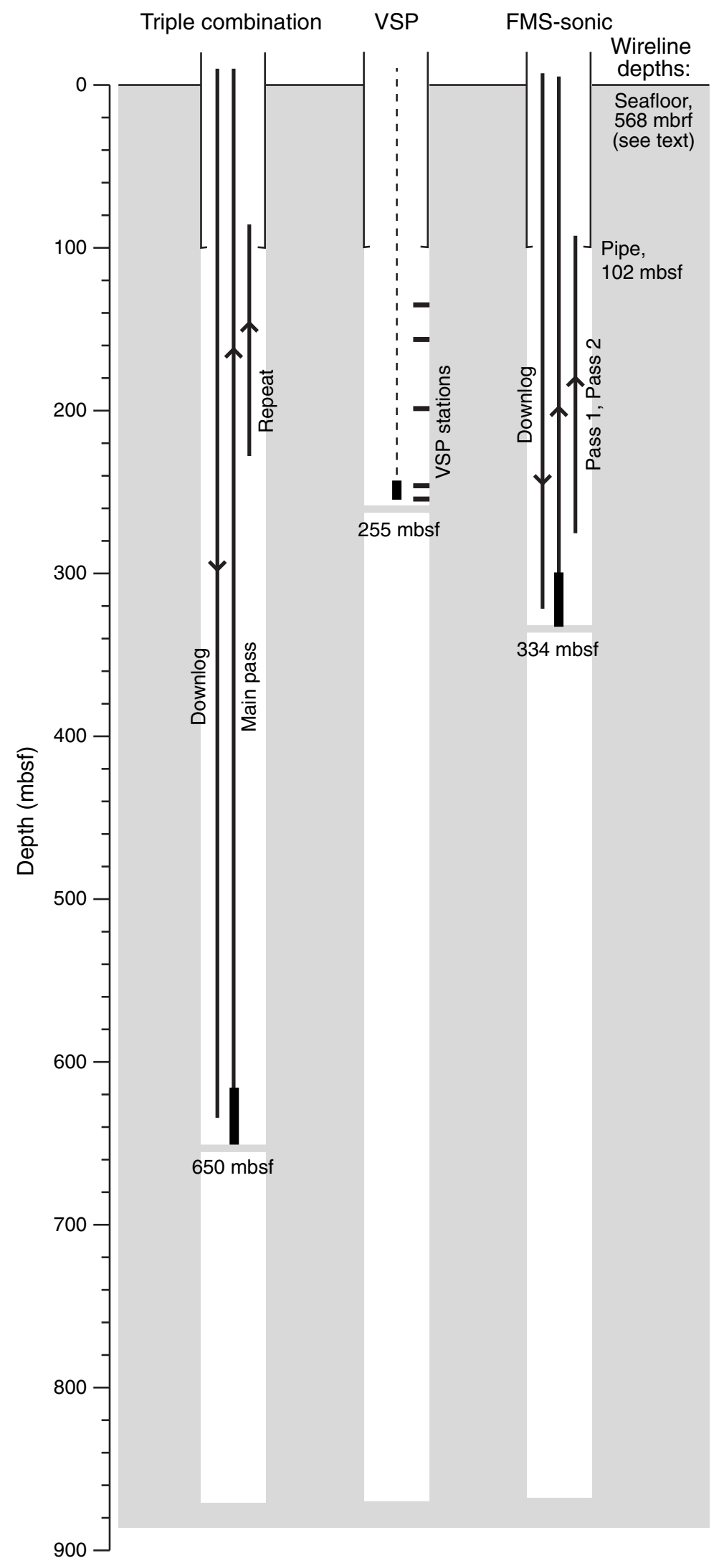


Figure F41. Plots of tides and ship heave, Site U1387. Tides were calculated using Tide Model Driver, a Matlab front-end for the Oregon State University Tidal Data Inversion (Egbert and Erofeeva, 2002). Ship heave was derived from acceleration measured by the motion reference unit in the moonpool area. APCT-3 = advanced piston corer temperature tool, FMS = Formation MicroScanner, RMS = root-mean square.

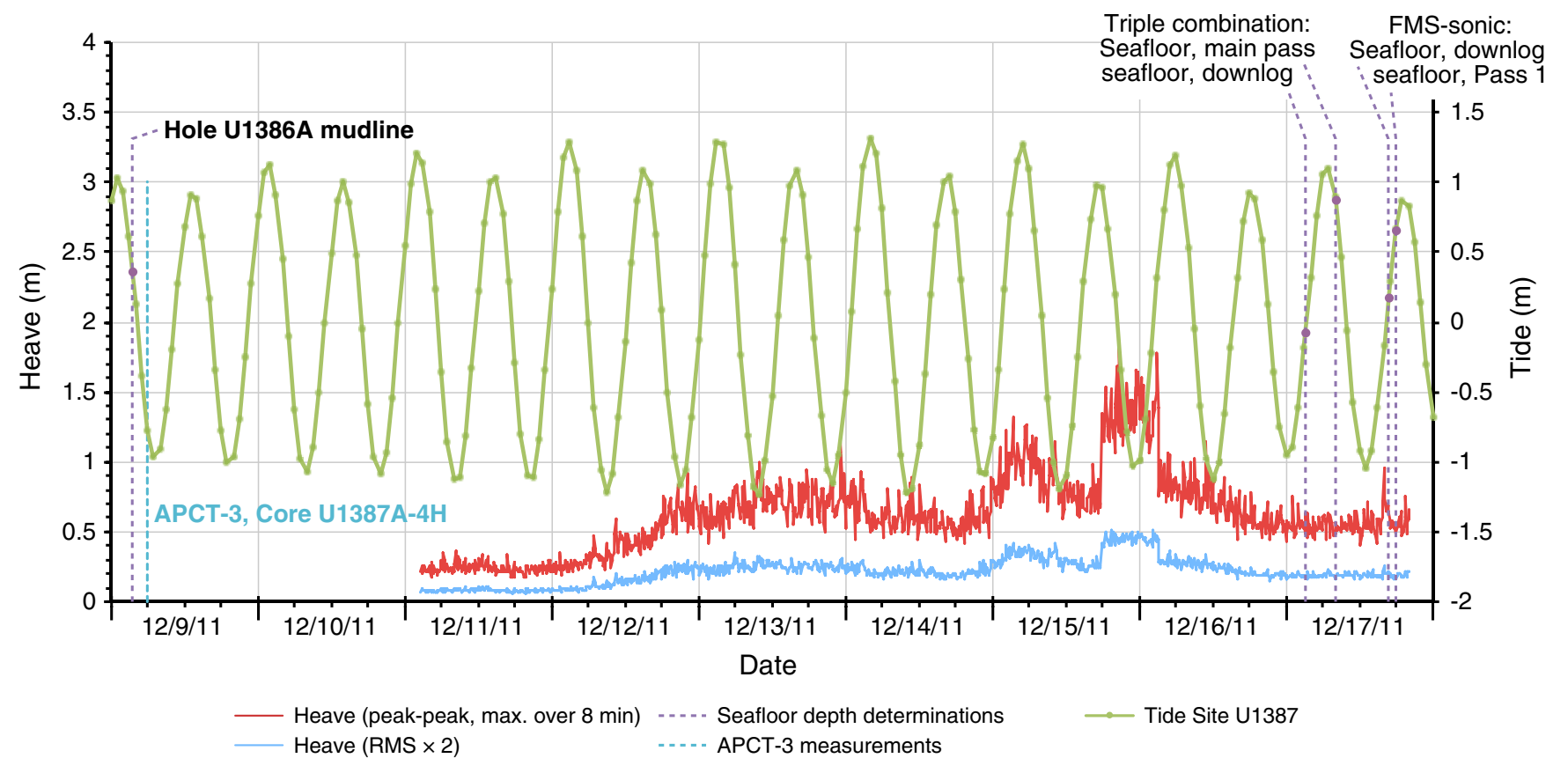


Figure F42. Downhole logs and logging units, Hole U1387C. HSGR = standard (total) gamma radiation, MAD $=$ moisture and density discrete samples, RT $=$ "true" resistivity, RLA5 = deep apparent resistivity, PWC $=P$-wave caliper.

Hole U1387C

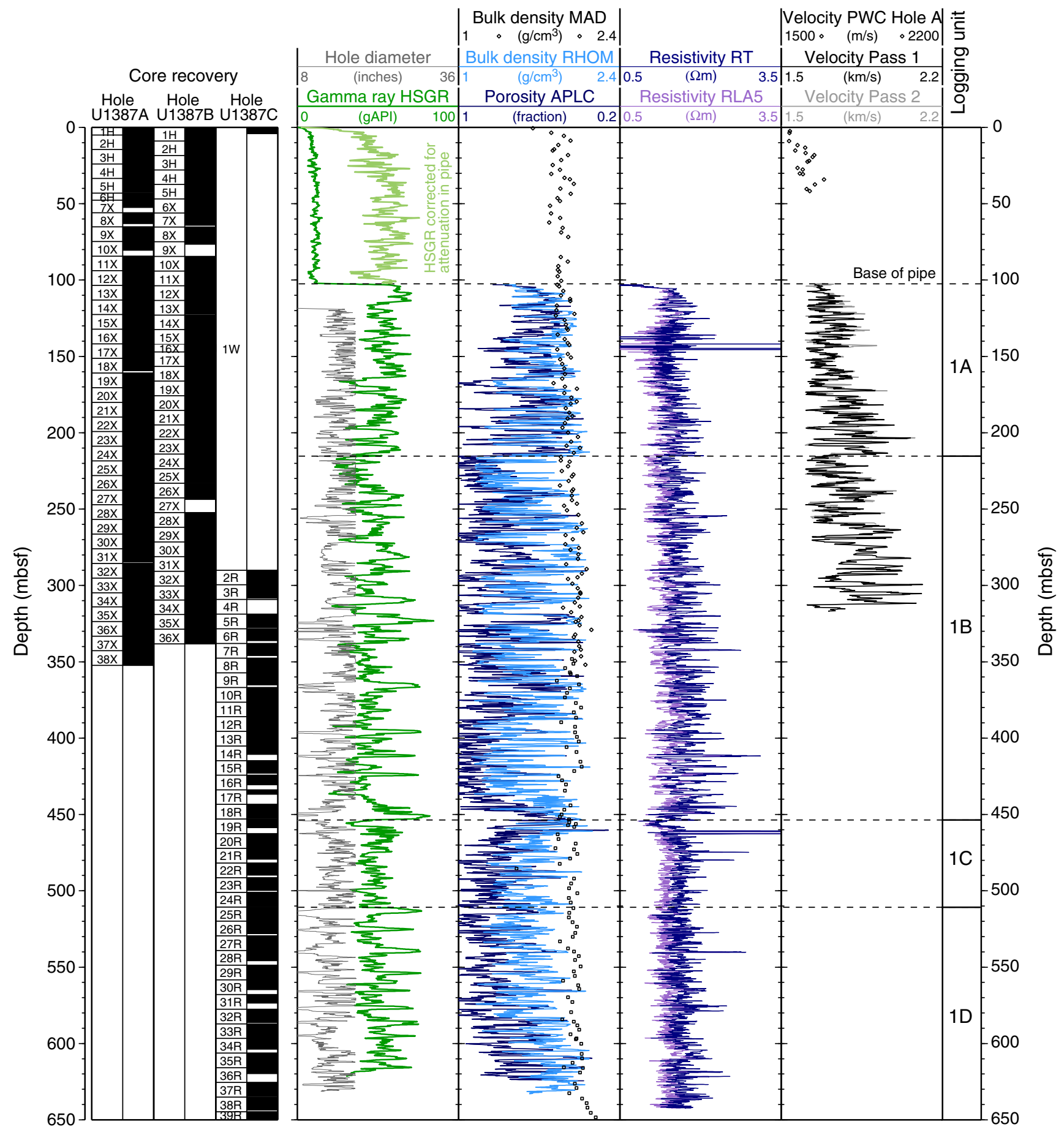


Figure F43. Natural gamma radiation logs and logging units, Hole U1387C. Logs are uncorrected for variations in hole diameter. HSGR = standard (total) gamma radiation.

Hole U1387C
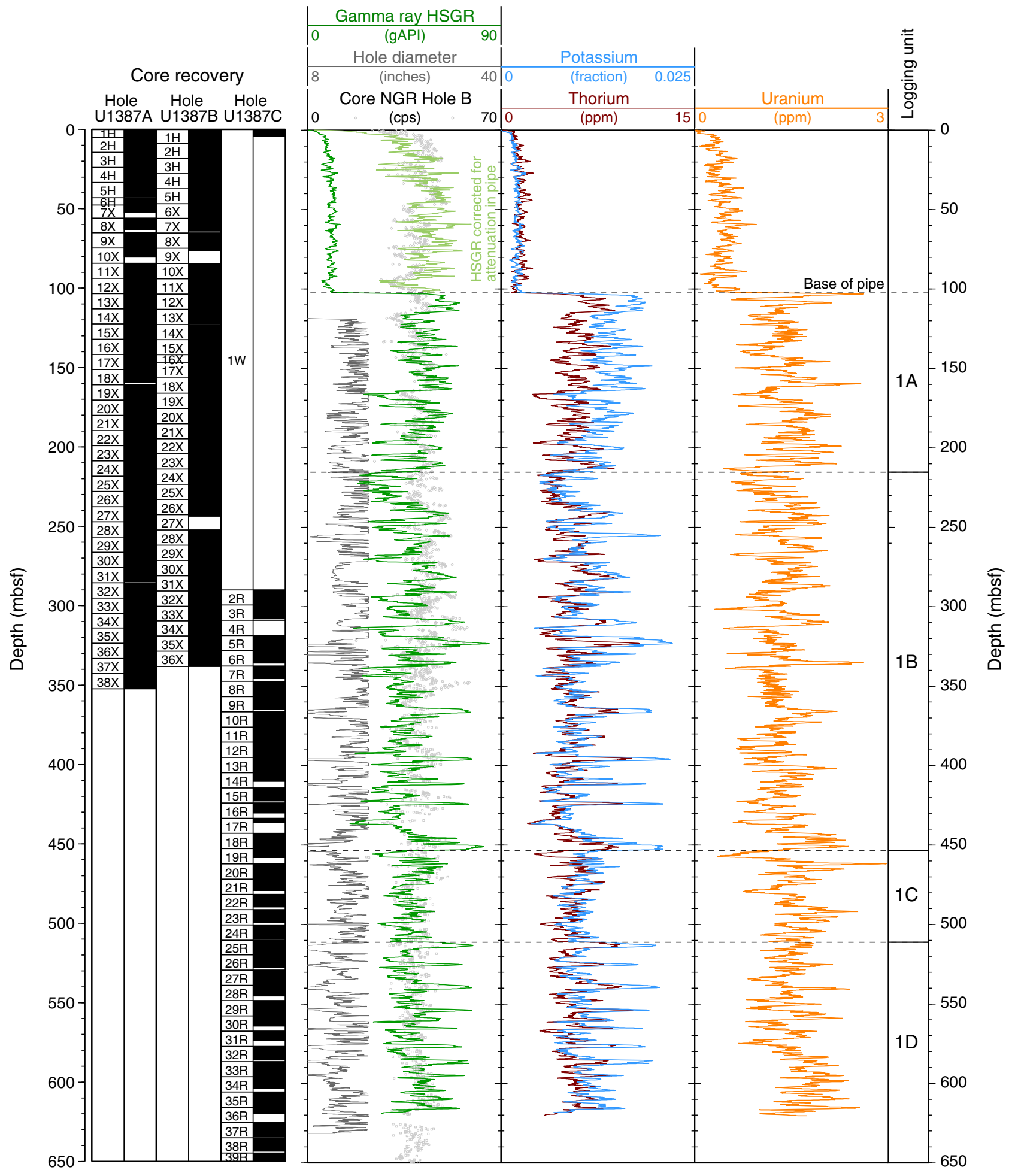
Figure F44. Lithology and downhole logs of example intervals in Holes U1387A and U1387C with cyclic alternations and their correlation with sand/clay-rich alternations (see "Lithostratigraphy"). NGR = natural gamma radiation, HSGR = standard (total) gamma radiation. n.m. = nannofossil mud, s.m. = silty mud, s.s. = silty sand, d.n.m. = very dark greenish gray nannofossil mud.
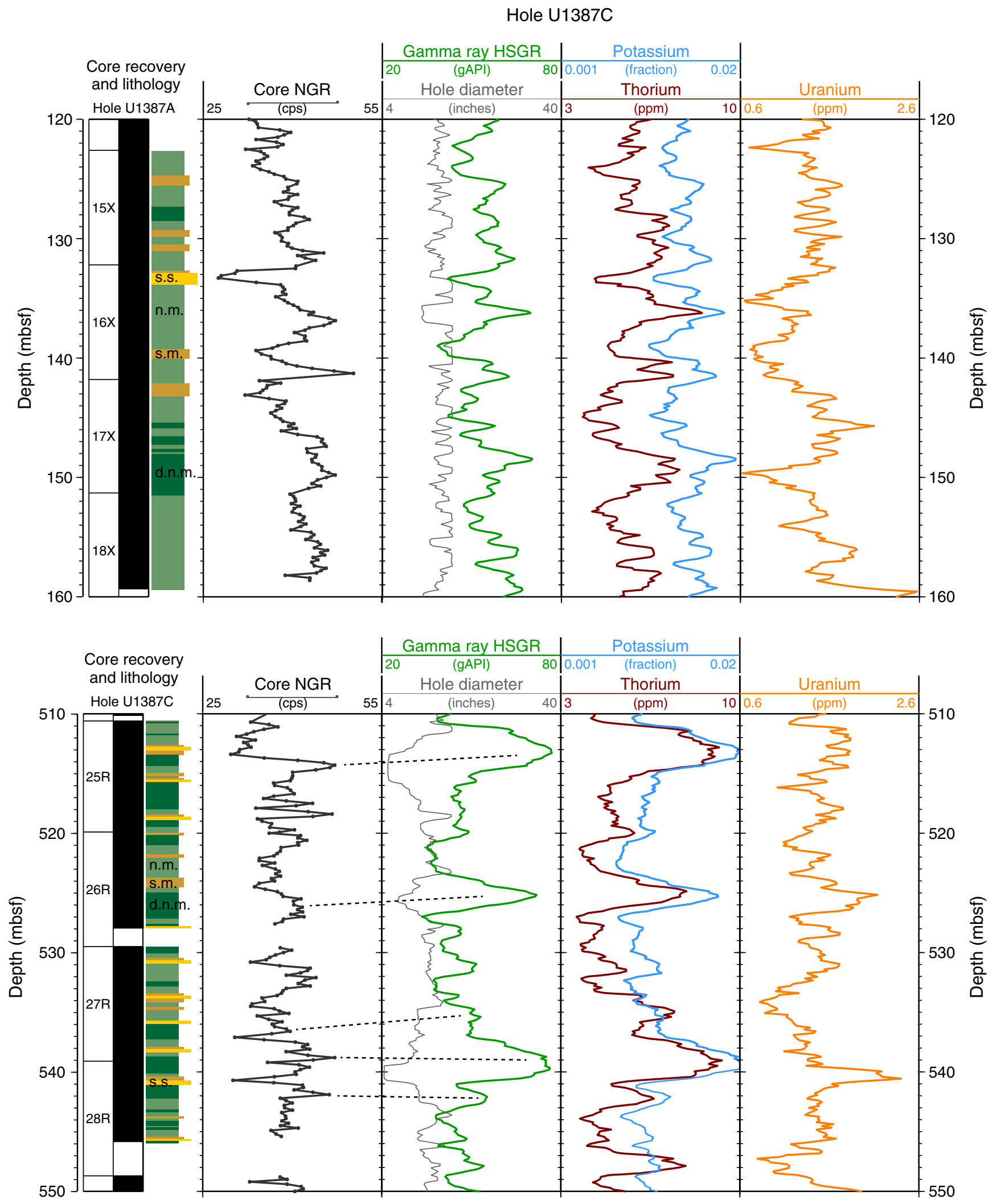
Figure F45. Comparison of downhole logs from Hole U1387C and lithology from Hole U1387A. The wide hole made it difficult for the Formation MicroScanner (FMS) pads to have good contact with the borehole wall, and the images often appear out of focus as a result. HSGR = standard (total) gamma radiation, RLA5 = deep apparent resistivity. n.m. $=$ nannofossil mud, s.m. $=$ silty mud, s.s. $=$ silty sand.

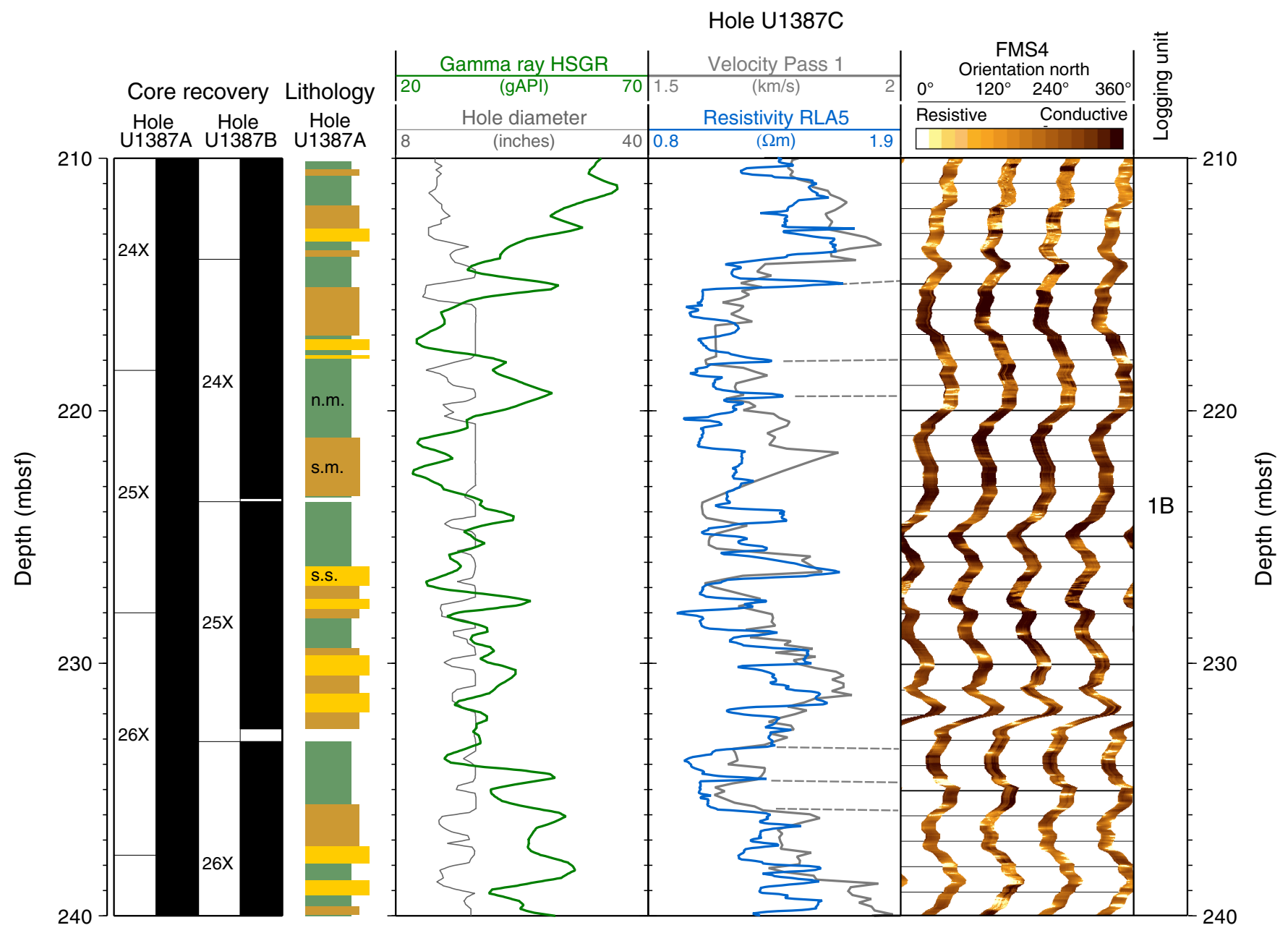


Figure F46. Plots of vertical seismic profile waveforms and one-way traveltime picks, Hole U1387C.

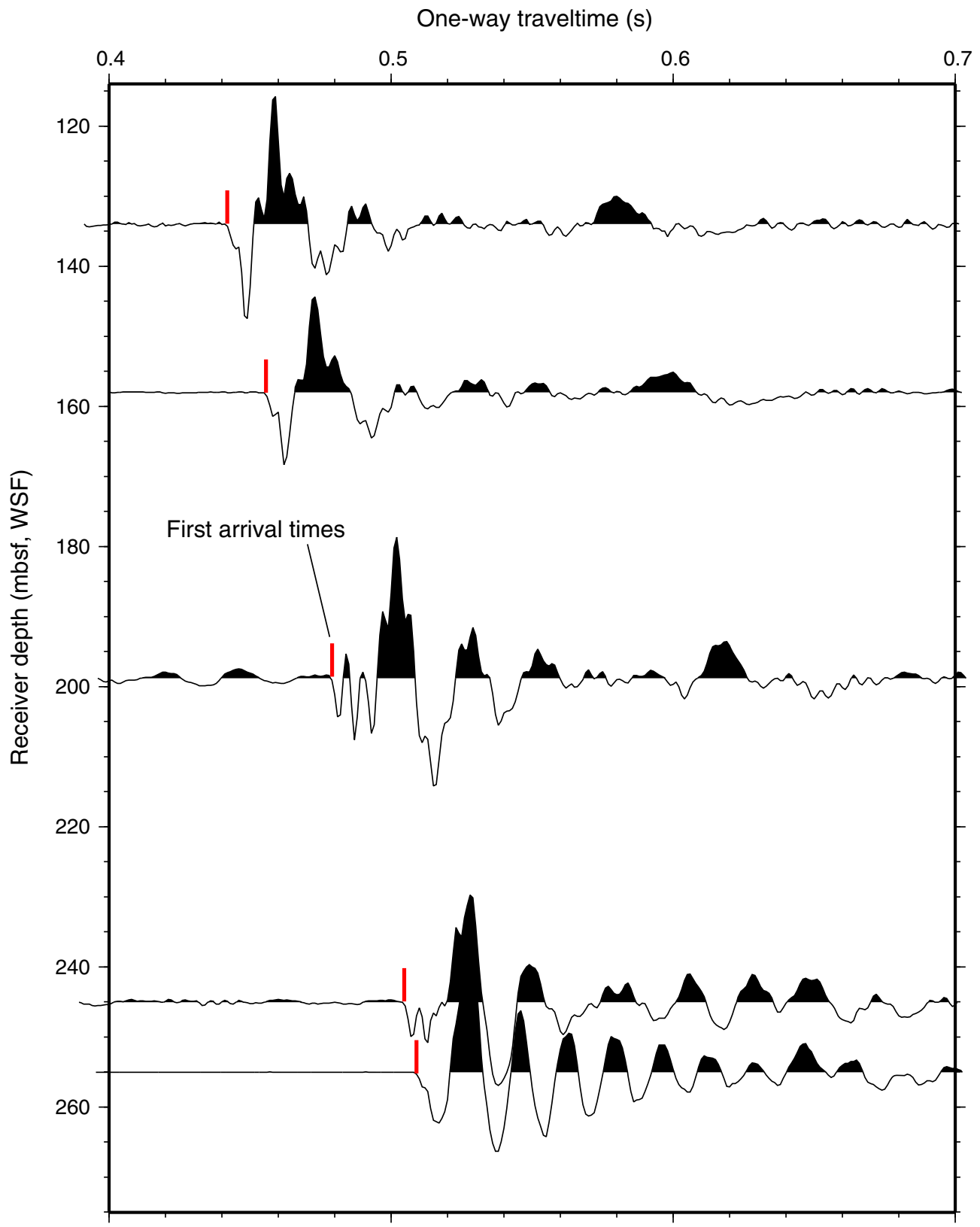


Figure F47. Plots of magnetic susceptibility vs. composite depth, Site U1387. Susceptibility values for Holes U1387B and U1387C are shifted in the lower panels for display purposes. A. 0-80 mcd. (Continued on next four pages.)

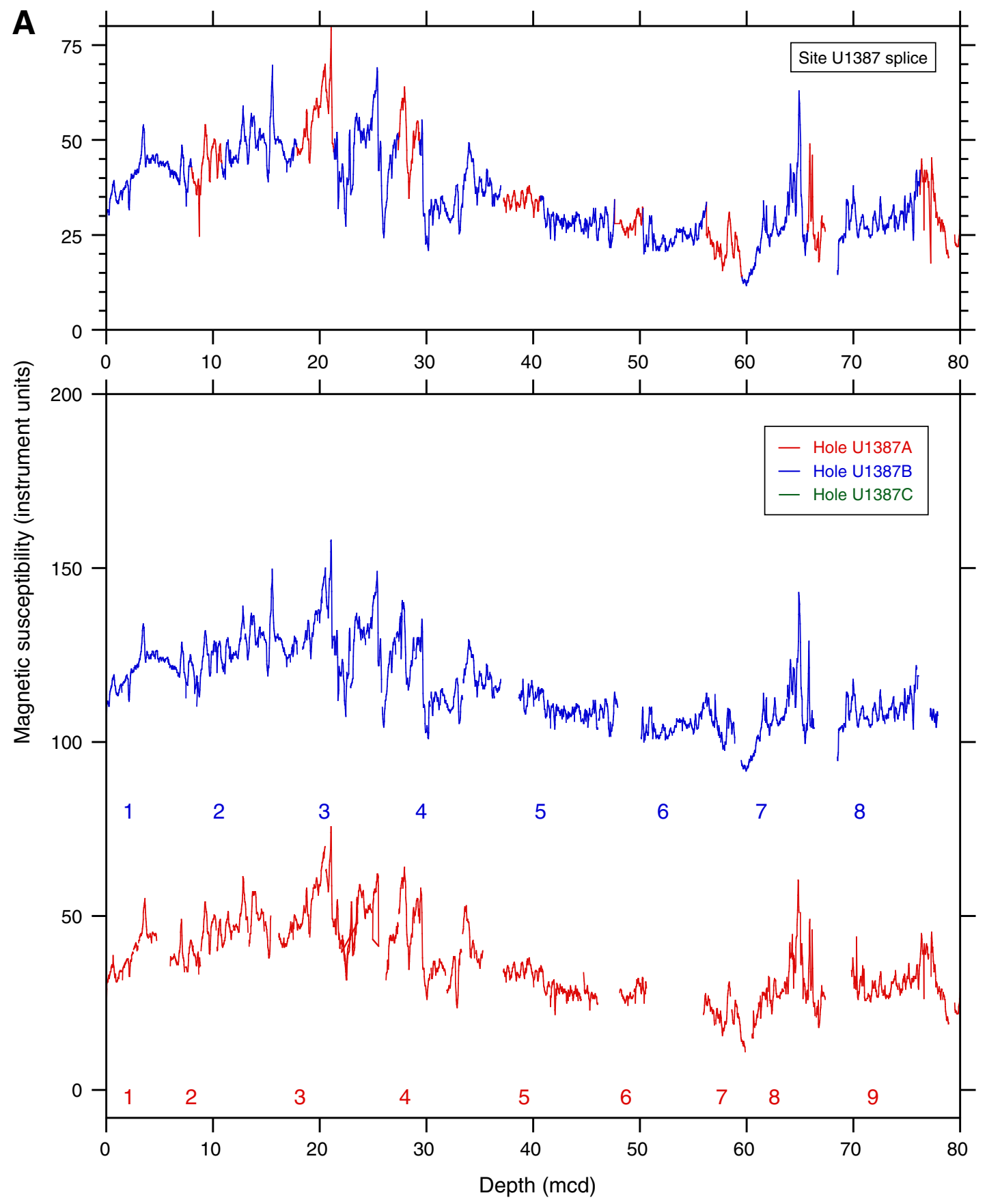


Figure F47 (continued). B. 80-160 mcd. (Continued on next page.)

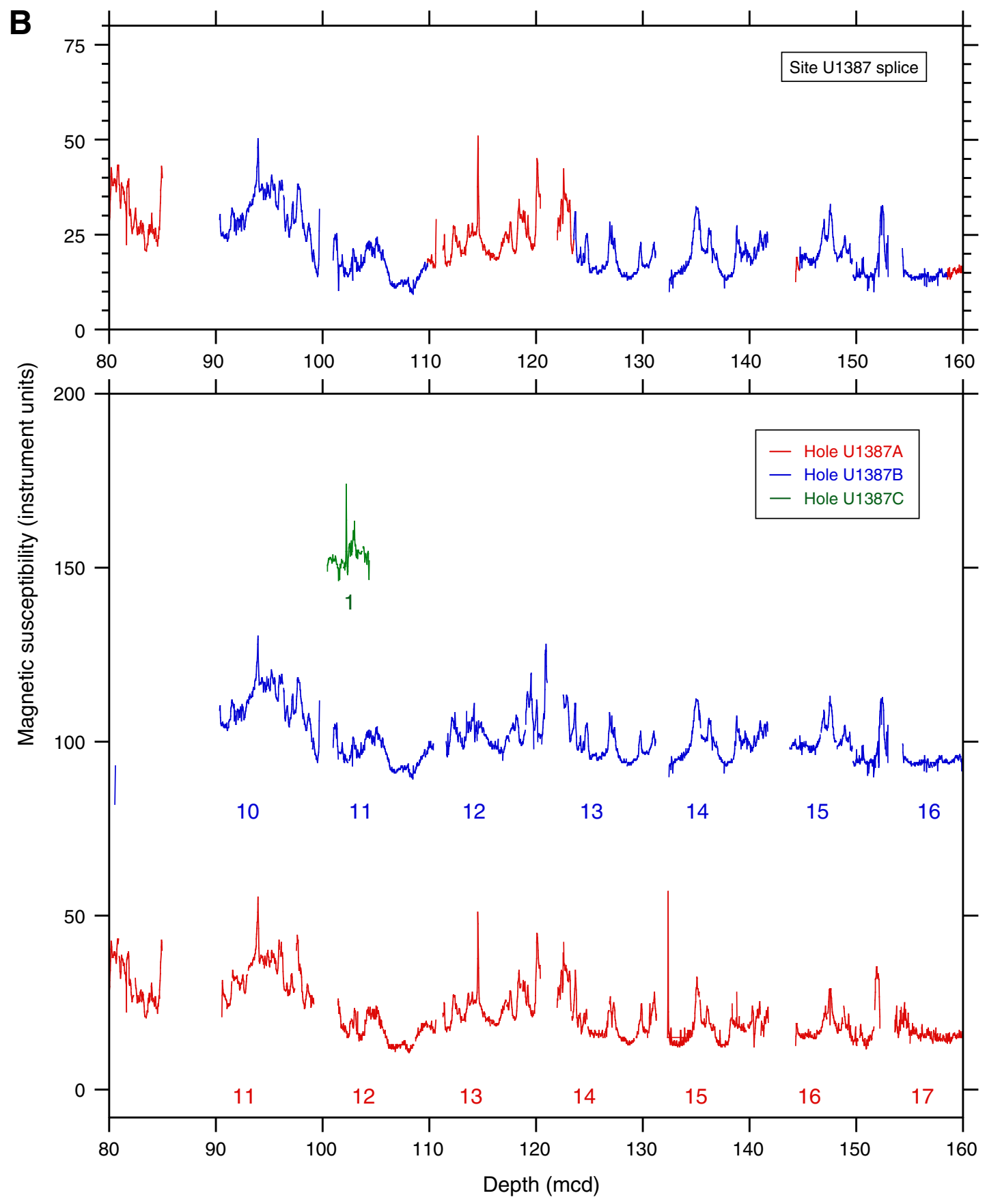


Figure F47 (continued). C. 160-240 mcd. (Continued on next page.)

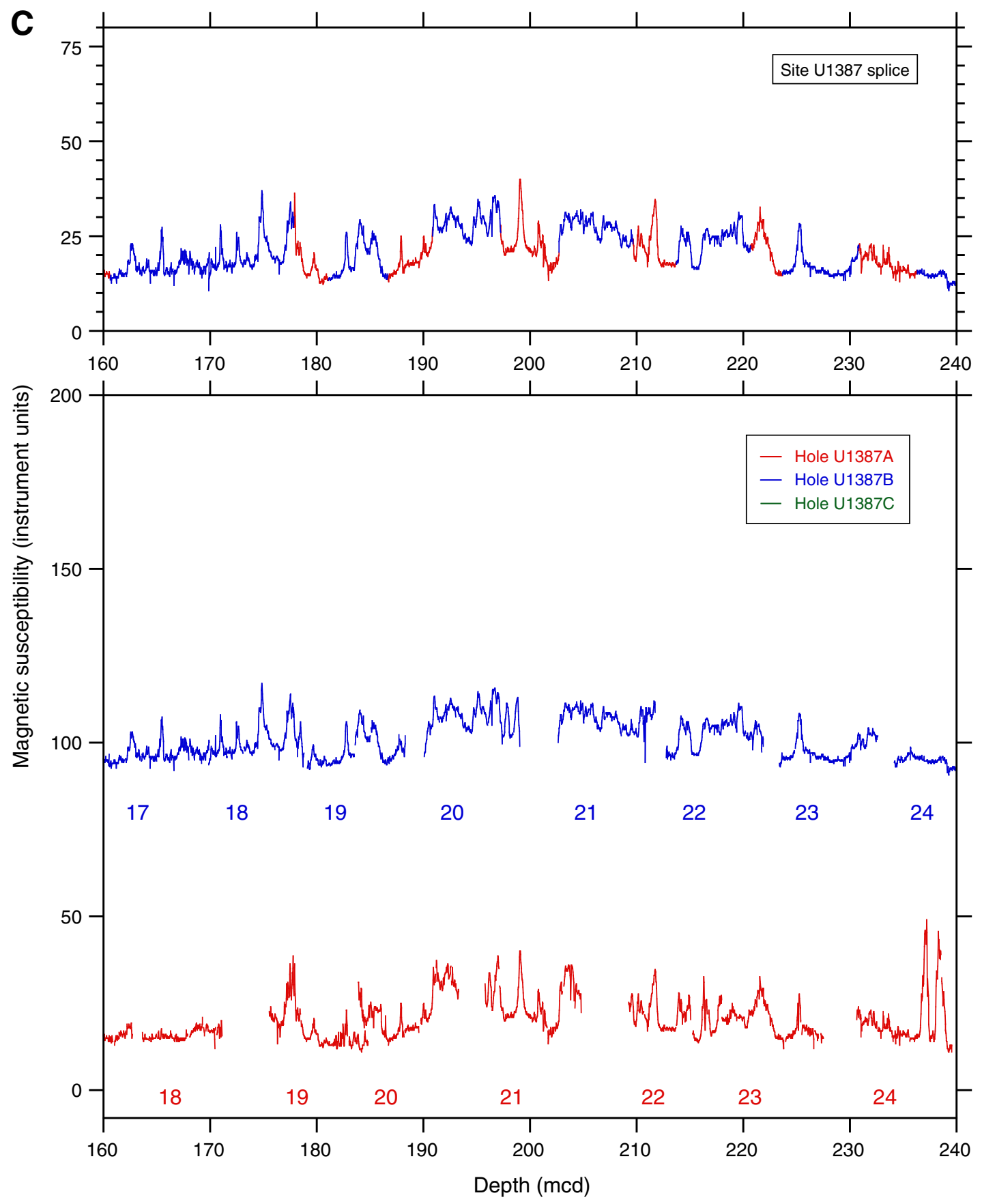


Figure F47 (continued). D. 240-320 mcd. (Continued on next page.)

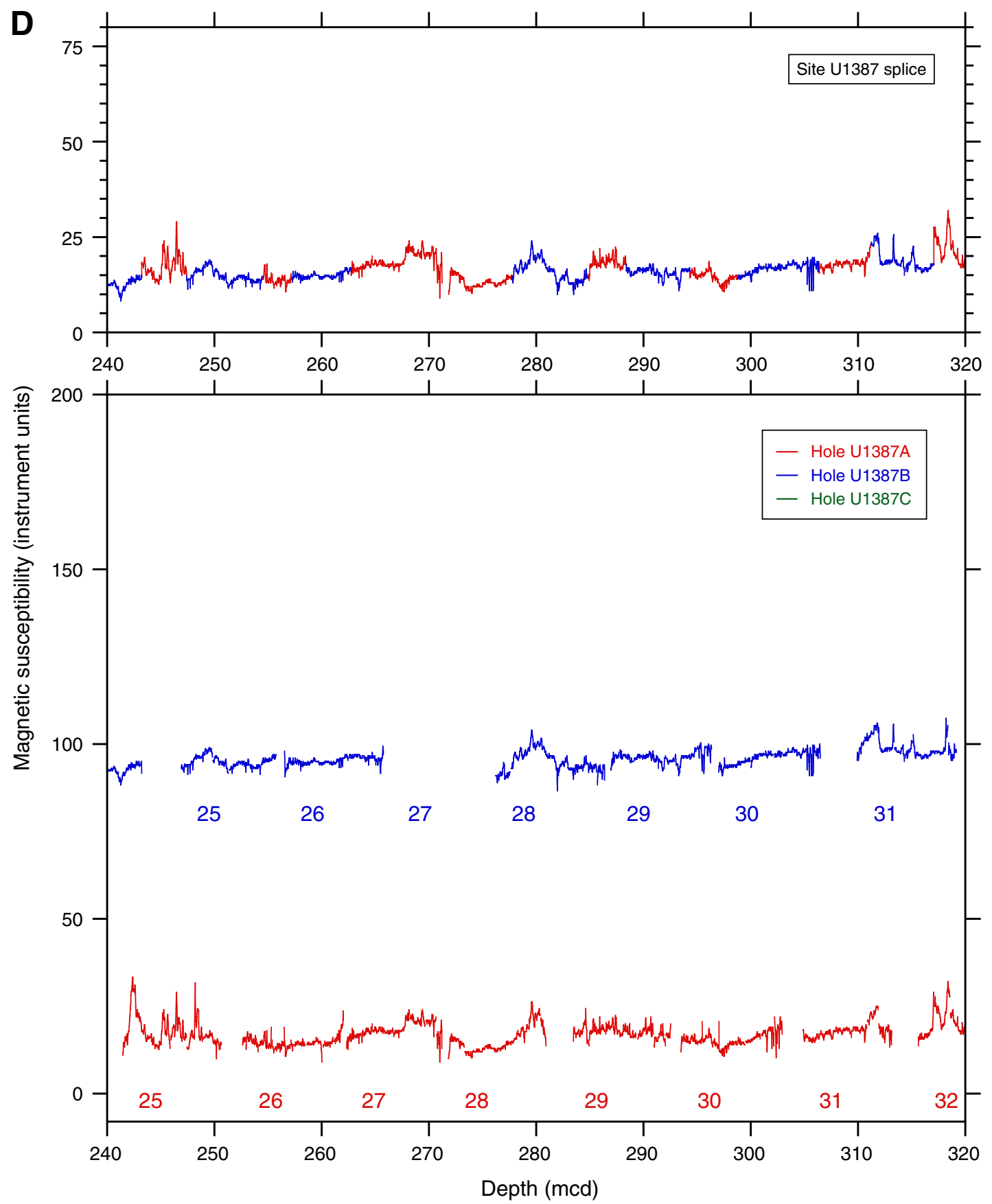


Figure F47 (continued). E. 320-400 mcd.

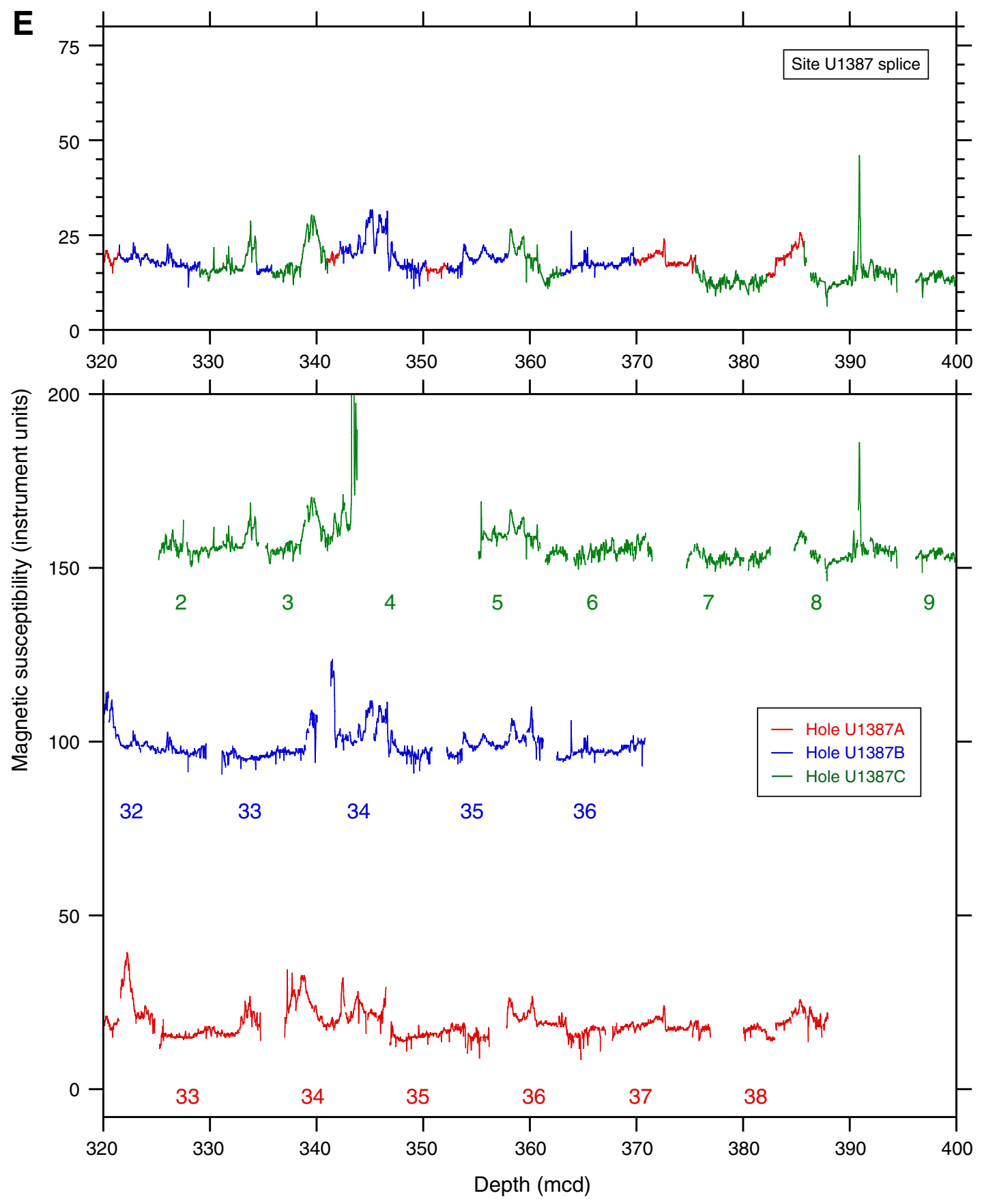


Figure F48. Natural gamma radiation (NGR) vs. composite depth, Site U1387. NGR values for Holes U1387B and U1387C are shifted in the lower panels for display purposes. Data are shown only for the multi-cored intervals. A. $0-80 \mathrm{mcd}$. (Continued on next four pages.)

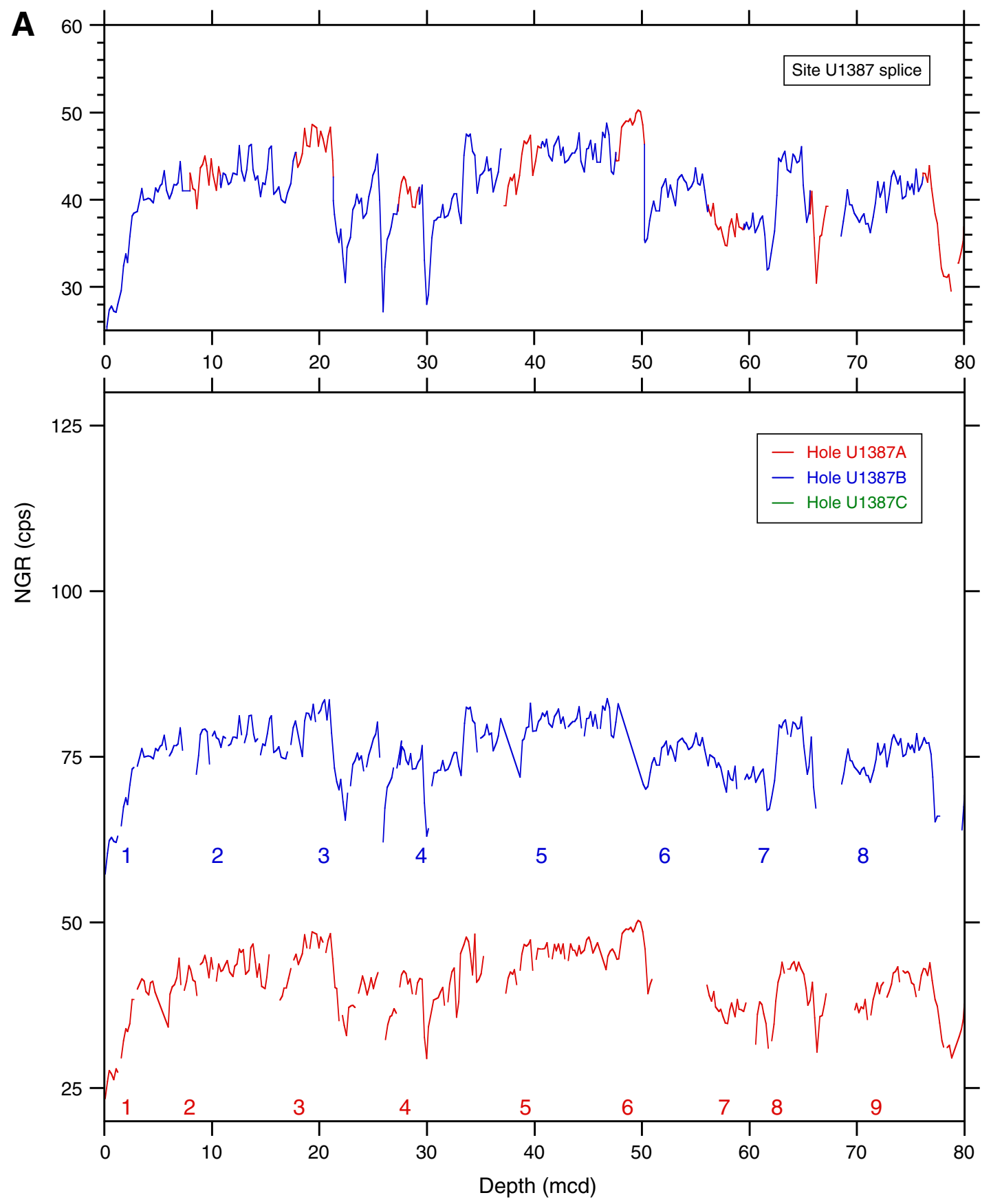


Figure F48 (continued). B. 80-160 mcd. (Continued on next page.)




Figure F48 (continued). C. 160-240 mcd. (Continued on next page.)
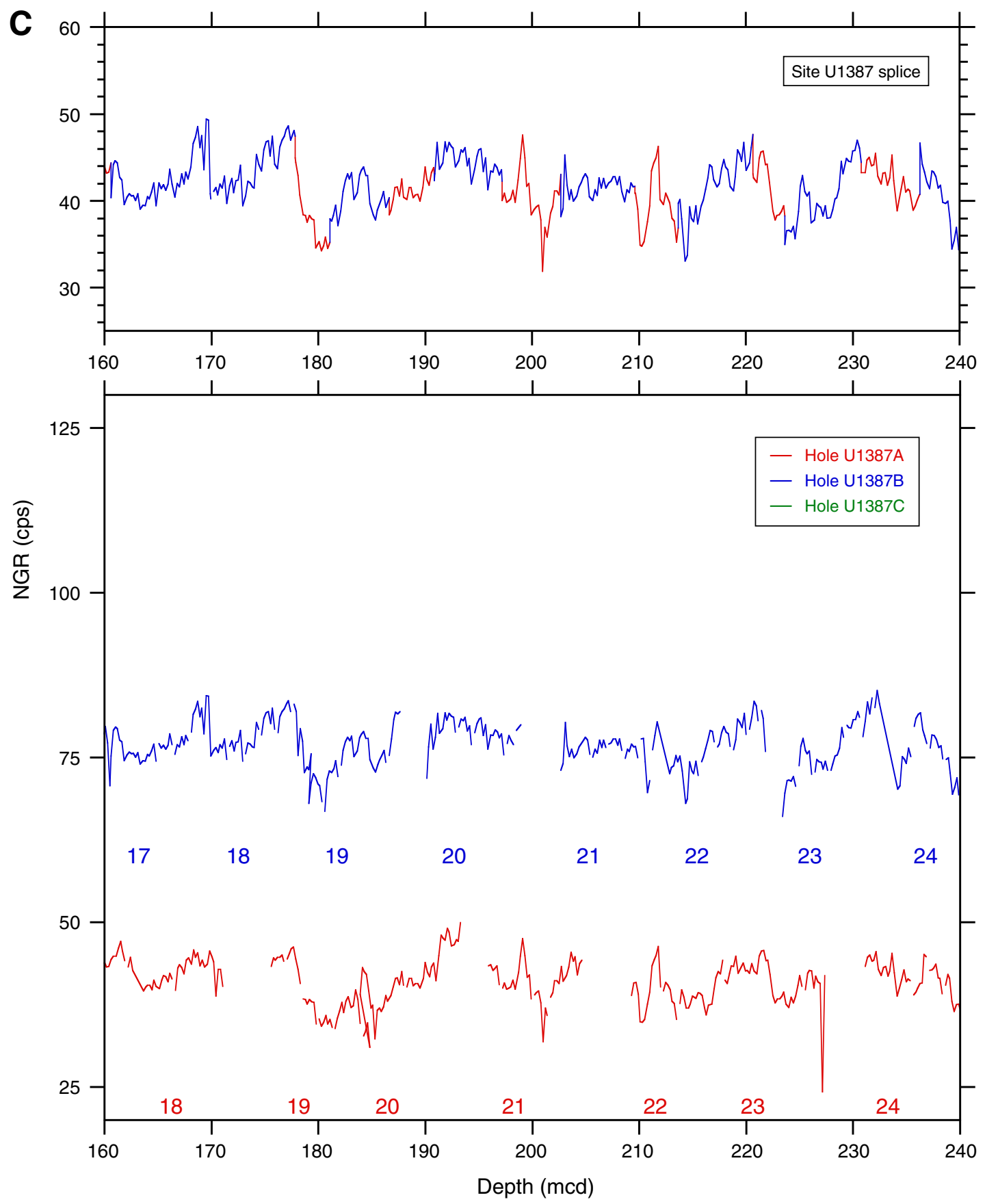
Figure F48 (continued). D. 240-320 mcd. (Continued on next page.)

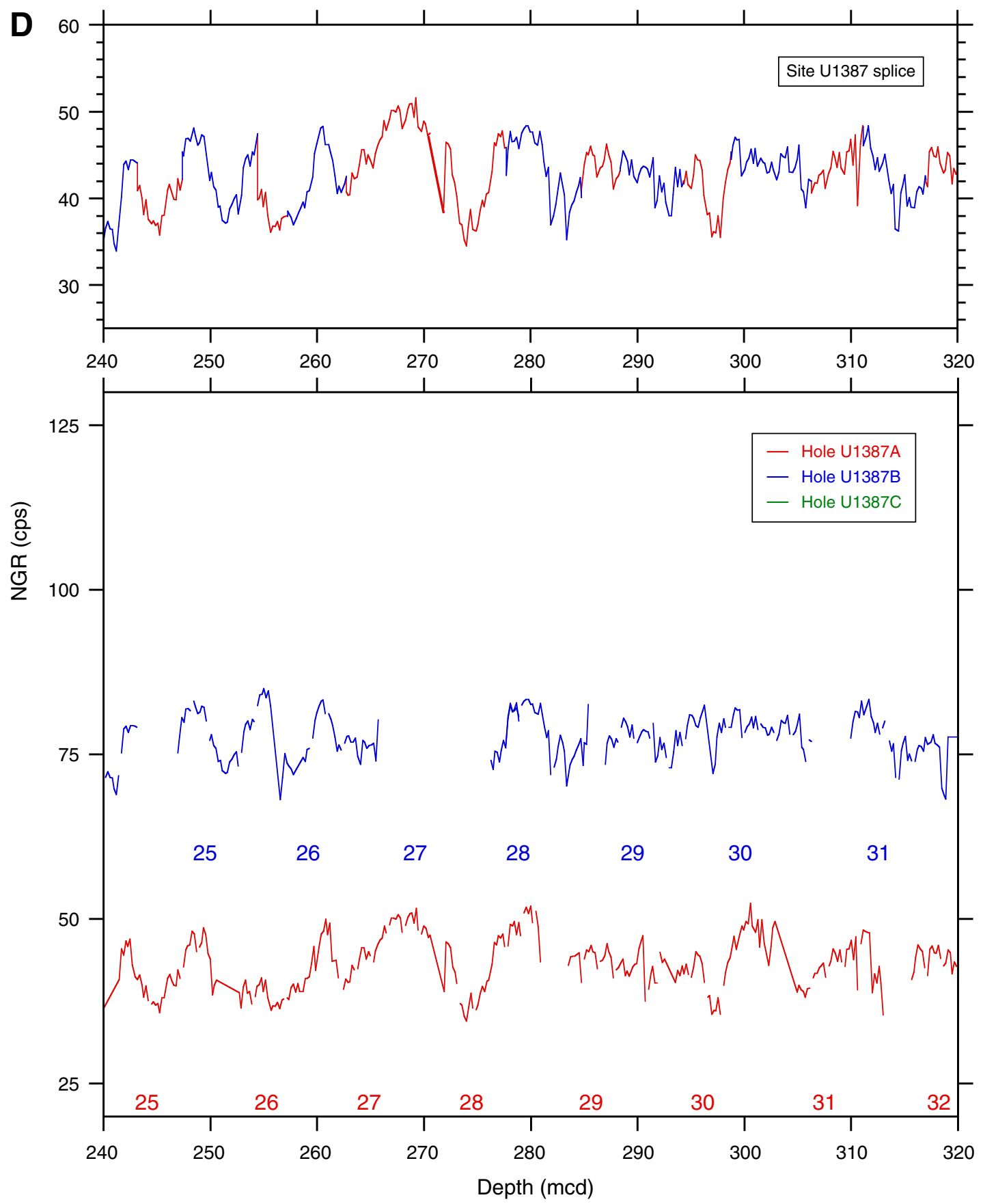


Figure F48 (continued). E. 320-400 mcd.

Figure F49. Plot of core top depths for mbsf vs. mcd. The best-fit line (not shown) is for $10.5 \%$ expansion.

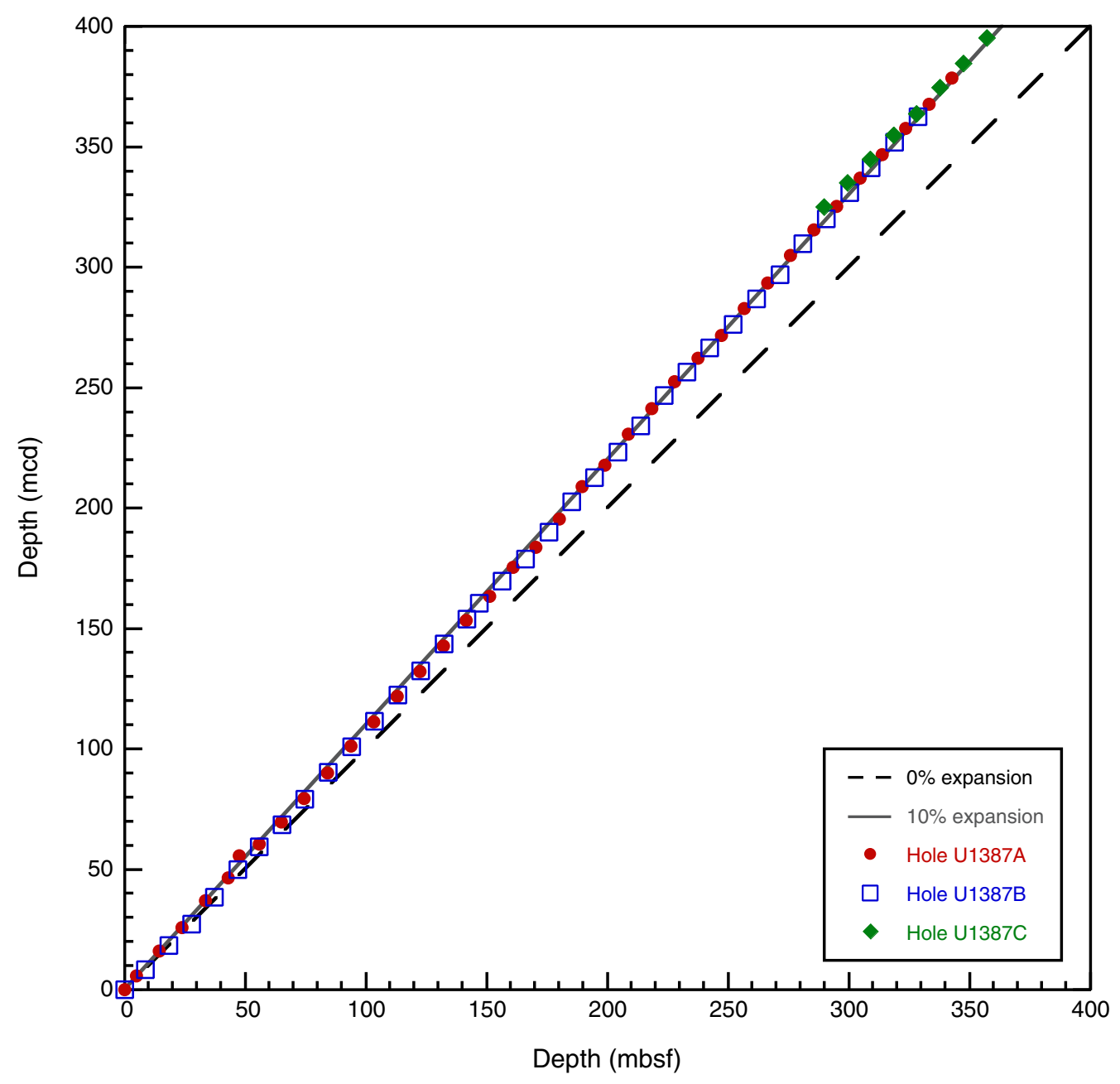


Table T1. Coring summary, Site U1387. (Continued on next two pages.)

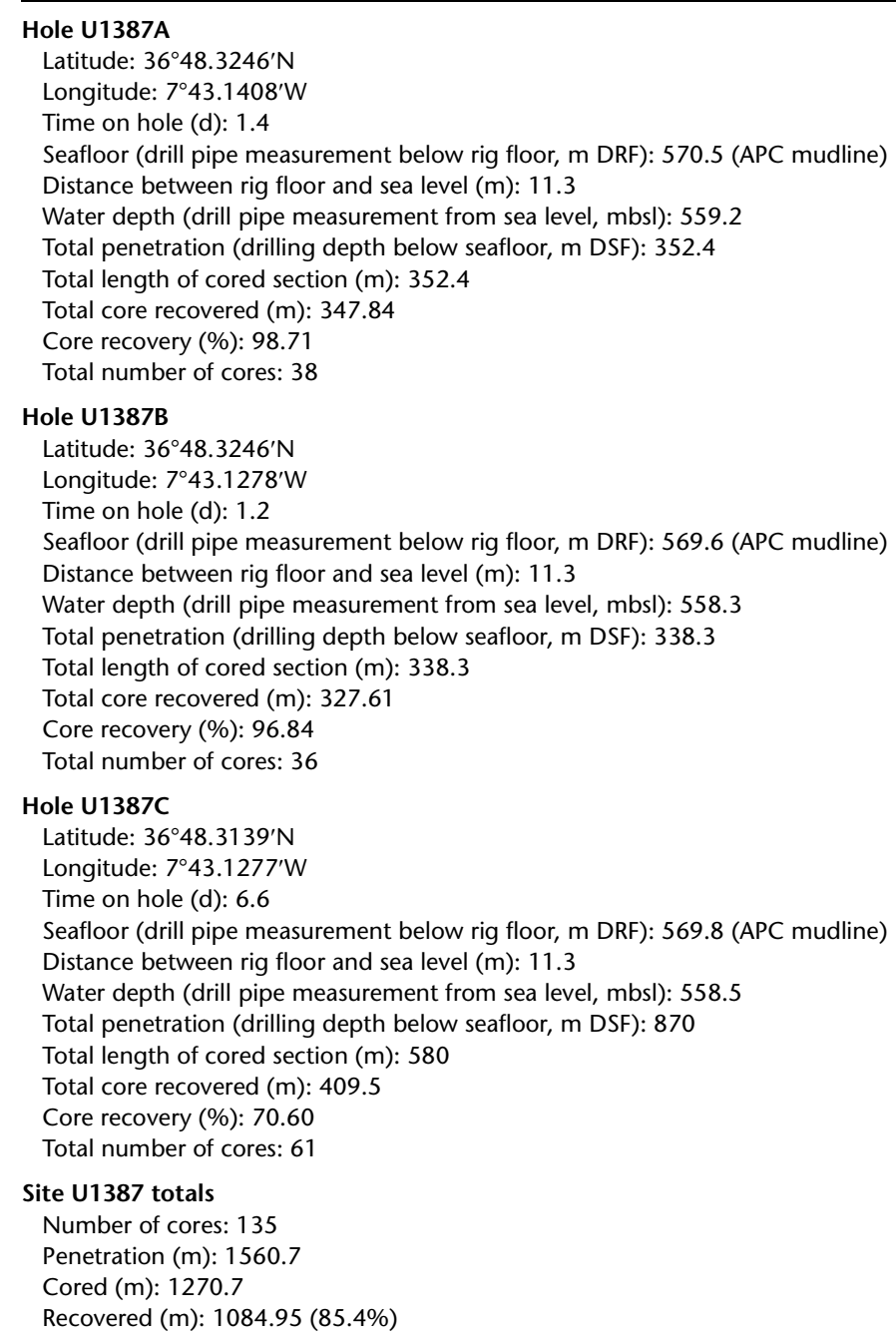

\begin{tabular}{|c|c|c|c|c|c|c|c|c|c|c|}
\hline \multirow[b]{2}{*}{ Core } & \multirow[b]{2}{*}{$\begin{array}{l}\text { Date } \\
(2011)\end{array}$} & \multirow[b]{2}{*}{$\begin{array}{l}\text { Time } \\
\text { (h) }\end{array}$} & \multicolumn{2}{|c|}{ Depth DSF (m) } & \multirow[b]{2}{*}{$\begin{array}{c}\text { Interval } \\
\text { advanced (m) }\end{array}$} & \multicolumn{2}{|c|}{ Depth CSF (m) } & \multirow[b]{2}{*}{$\begin{array}{l}\text { Length of core } \\
\text { recovered }(m)\end{array}$} & \multirow[b]{2}{*}{$\begin{array}{l}\text { Curated } \\
\text { length }(\mathrm{m})\end{array}$} & \multirow[b]{2}{*}{$\begin{array}{l}\text { Recovery } \\
\text { (\%) }\end{array}$} \\
\hline & & & $\begin{array}{l}\text { Top of cored } \\
\text { interval }\end{array}$ & $\begin{array}{l}\text { Bottom of } \\
\text { cored interval }\end{array}$ & & $\begin{array}{c}\text { Top of } \\
\text { recovered core }\end{array}$ & $\begin{array}{l}\text { Bottom of } \\
\text { recovered core }\end{array}$ & & & \\
\hline \multicolumn{11}{|c|}{ 339-U1387A- } \\
\hline $1 \mathrm{H}$ & $9 \mathrm{Dec}$ & 0335 & 0.0 & 5.0 & 5.0 & 0.0 & 5.07 & 5.07 & 5.07 & 102 \\
\hline $2 \mathrm{H}$ & $9 \mathrm{Dec}$ & 0435 & 5.0 & 14.5 & 9.5 & 5.0 & 14.92 & 9.92 & 9.92 & 103 \\
\hline $3 \mathrm{H}$ & $9 \mathrm{Dec}$ & 0510 & 14.5 & 24.0 & 9.5 & 14.5 & 24.31 & 9.81 & 9.81 & 105 \\
\hline $4 \mathrm{H}$ & $9 \mathrm{Dec}$ & 0615 & 24.0 & 33.5 & 9.5 & 24.0 & 34.08 & 10.08 & 10.08 & 109 \\
\hline $5 \mathrm{H}$ & $9 \mathrm{Dec}$ & 0705 & 33.5 & 43.0 & 9.5 & 33.5 & 42.69 & 9.19 & 9.19 & 104 \\
\hline $6 \mathrm{H}$ & $9 \mathrm{Dec}$ & 0800 & 43.0 & 47.7 & 4.7 & 43.0 & 47.76 & 4.76 & 4.76 & 89 \\
\hline $7 X$ & $9 \mathrm{Dec}$ & 1045 & 47.7 & 55.9 & 8.2 & 47.7 & 52.56 & 4.86 & 4.86 & 105 \\
\hline $8 X$ & $9 \mathrm{Dec}$ & 1135 & 55.9 & 65.1 & 9.2 & 55.9 & 63.17 & 7.27 & 7.27 & 103 \\
\hline $9 X$ & $9 \mathrm{Dec}$ & 1210 & 65.1 & 74.7 & 9.6 & 65.1 & 74.76 & 9.66 & 9.66 & 103 \\
\hline $10 x$ & $9 \mathrm{Dec}$ & 1235 & 74.7 & 84.3 & 9.6 & 74.7 & 80.53 & 5.83 & 5.83 & 108 \\
\hline $11 x$ & $9 \mathrm{Dec}$ & 1305 & 84.3 & 93.9 & 9.6 & 84.3 & 94.12 & 9.82 & 9.82 & 83 \\
\hline $12 X$ & $9 \mathrm{Dec}$ & 1330 & 93.9 & 103.5 & 9.6 & 93.9 & 103.71 & 9.81 & 9.81 & 104 \\
\hline $13 x$ & $9 \mathrm{Dec}$ & 1355 & 103.5 & 113.1 & 9.6 & 103.5 & 113.39 & 9.89 & 9.89 & 105 \\
\hline $14 X$ & $9 \mathrm{Dec}$ & 1420 & 113.1 & 122.6 & 9.5 & 113.1 & 122.99 & 9.87 & 9.89 & 96 \\
\hline $15 X$ & $9 \mathrm{Dec}$ & 1445 & 122.6 & 132.2 & 9.6 & 122.6 & 132.43 & 9.83 & 9.83 & 102 \\
\hline $16 X$ & $9 \mathrm{Dec}$ & 1515 & 132.2 & 141.8 & 9.6 & 132.2 & 141.81 & 9.61 & 9.61 & 99 \\
\hline $17 x$ & $9 \mathrm{Dec}$ & 1545 & 141.8 & 151.3 & 9.5 & 141.8 & 151.33 & 9.53 & 9.53 & 101 \\
\hline $18 \mathrm{X}$ & $9 \mathrm{Dec}$ & 1610 & 151.3 & 160.9 & 9.6 & 151.3 & 159.35 & 8.05 & 8.05 & 101 \\
\hline $19 x$ & $9 \mathrm{Dec}$ & 1635 & 160.9 & 170.5 & 9.6 & 160.9 & 170.65 & 9.75 & 9.75 & 101 \\
\hline $20 x$ & $9 \mathrm{Dec}$ & 1705 & 170.5 & 180.1 & 9.6 & 170.5 & 180.44 & 9.94 & 9.94 & 114 \\
\hline $21 X$ & $9 \mathrm{Dec}$ & 1745 & 180.1 & 189.7 & 9.6 & 180.1 & 189.69 & 9.59 & 9.59 & 100 \\
\hline $22 X$ & $9 \mathrm{Dec}$ & 1815 & 189.7 & 199.2 & 9.5 & 189.7 & 199.21 & 9.51 & 9.51 & 162 \\
\hline $23 x$ & $9 \mathrm{Dec}$ & 1840 & 199.2 & 208.8 & 9.6 & 199.2 & 209.09 & 9.89 & 9.89 & 103 \\
\hline
\end{tabular}


Table T1 (continued). (Continued on next page.)

\begin{tabular}{|c|c|c|c|c|c|c|c|c|c|c|}
\hline \multirow[b]{2}{*}{ Core } & \multirow[b]{2}{*}{$\begin{array}{l}\text { Date } \\
\text { (2011) }\end{array}$} & \multirow[b]{2}{*}{$\begin{array}{c}\text { Time } \\
\text { (h) }\end{array}$} & \multicolumn{2}{|c|}{ Depth DSF $(m)$} & \multirow[b]{2}{*}{$\begin{array}{c}\text { Interval } \\
\text { advanced (m) }\end{array}$} & \multicolumn{2}{|c|}{ Depth CSF (m) } & \multirow[b]{2}{*}{$\begin{array}{l}\text { Length of core } \\
\text { recovered }(\mathrm{m})\end{array}$} & \multirow[b]{2}{*}{$\begin{array}{l}\text { Curated } \\
\text { length }(m)\end{array}$} & \multirow[b]{2}{*}{$\begin{array}{l}\text { Recovery } \\
(\%)\end{array}$} \\
\hline & & & $\begin{array}{c}\text { Top of cored } \\
\text { interval }\end{array}$ & $\begin{array}{c}\text { Bottom of } \\
\text { cored interval }\end{array}$ & & $\begin{array}{c}\text { Top of } \\
\text { recovered core }\end{array}$ & $\begin{array}{l}\text { Bottom of } \\
\text { recovered core }\end{array}$ & & & \\
\hline $24 X$ & $9 \mathrm{Dec}$ & 1910 & 208.8 & 218.4 & 9.6 & 208.8 & 218.71 & 9.91 & 9.91 & 98 \\
\hline $25 x$ & $9 \mathrm{Dec}$ & 1945 & 218.4 & 228.0 & 9.6 & 218.4 & 228.09 & 9.69 & 9.69 & 101 \\
\hline $26 \mathrm{X}$ & $9 \mathrm{Dec}$ & 2010 & 228.0 & 237.6 & 9.6 & 228.0 & 237.83 & 9.83 & 9.83 & 100 \\
\hline $27 X$ & $9 \mathrm{Dec}$ & 2045 & 237.6 & 247.2 & 9.6 & 237.6 & 247.04 & 9.44 & 9.44 & 103 \\
\hline $28 \mathrm{X}$ & $9 \mathrm{Dec}$ & 2120 & 247.2 & 256.8 & 9.6 & 247.2 & 256.74 & 9.54 & 9.54 & 104 \\
\hline $29 x$ & $9 \mathrm{Dec}$ & 2150 & 256.8 & 266.4 & 9.6 & 256.8 & 266.86 & 10.06 & 10.06 & 102 \\
\hline $30 x$ & $9 \mathrm{Dec}$ & 2225 & 266.4 & 276.0 & 9.6 & 266.4 & 276.29 & 9.89 & 9.89 & 104 \\
\hline $31 x$ & $9 \mathrm{Dec}$ & 2255 & 276.0 & 285.6 & 9.6 & 276.0 & 284.81 & 8.81 & 8.81 & 107 \\
\hline $32 x$ & $9 \mathrm{Dec}$ & 2330 & 285.6 & 295.2 & 9.6 & 285.6 & 295.29 & 9.69 & 9.69 & 103 \\
\hline $33 x$ & $10 \mathrm{Dec}$ & 0030 & 295.2 & 304.8 & 9.6 & 295.2 & 305.05 & 9.85 & 9.85 & 102 \\
\hline $34 X$ & $10 \mathrm{Dec}$ & 0125 & 304.8 & 314.0 & 9.2 & 304.8 & 315.02 & 10.22 & 10.22 & 101 \\
\hline $35 x$ & $10 \mathrm{Dec}$ & 0225 & 314.0 & 323.6 & 9.6 & 314.0 & 323.85 & 9.85 & 9.85 & 97 \\
\hline $36 x$ & $10 \mathrm{Dec}$ & 0330 & 323.6 & 333.2 & 9.6 & 323.6 & 333.49 & 9.89 & 9.89 & 105 \\
\hline $37 x$ & $10 \mathrm{Dec}$ & 0420 & 333.2 & 342.8 & 9.6 & 333.2 & 342.88 & 9.68 & 9.68 & 101 \\
\hline $38 \mathrm{X}$ & $10 \mathrm{Dec}$ & 0520 & 342.8 & 352.4 & 9.6 & 342.8 & 352.75 & 9.95 & 9.95 & 89 \\
\hline & & & & vanced total: & 352.4 & & & & & \\
\hline & & & Total in & terval cored: & 347.84 & & & & & \\
\hline $339-U 138$ & & & & & & & & & & \\
\hline $1 \mathrm{H}$ & $10 \mathrm{Dec}$ & 1100 & 0.0 & 8.9 & 8.9 & 0.0 & 8.92 & 8.92 & 8.92 & 100 \\
\hline $2 \mathrm{H}$ & $10 \mathrm{Dec}$ & 1205 & 8.9 & 18.4 & 9.5 & 8.9 & 18.71 & 9.81 & 9.81 & 103 \\
\hline $3 \mathrm{H}$ & $10 \mathrm{Dec}$ & 1235 & 18.4 & 27.9 & 9.5 & 18.4 & 28.14 & 9.74 & 9.74 & 103 \\
\hline $4 \mathrm{H}$ & $10 \mathrm{Dec}$ & 1310 & 27.9 & 37.4 & 9.5 & 27.9 & 37.81 & 9.91 & 9.91 & 104 \\
\hline $5 \mathrm{H}$ & $10 \mathrm{Dec}$ & 1345 & 37.4 & 46.9 & 9.5 & 37.4 & 47.22 & 9.82 & 9.82 & 103 \\
\hline $6 \mathrm{X}$ & $10 \mathrm{Dec}$ & 1435 & 46.9 & 56.1 & 9.2 & 46.9 & 56.14 & 9.24 & 9.24 & 100 \\
\hline $7 X$ & $10 \mathrm{Dec}$ & 1500 & 56.1 & 65.3 & 9.2 & 56.1 & 64.18 & 8.08 & 8.08 & 88 \\
\hline $8 X$ & $10 \mathrm{Dec}$ & 1530 & 65.3 & 74.9 & 9.6 & 65.3 & 75.09 & 9.79 & 9.79 & 102 \\
\hline $9 x$ & $10 \mathrm{Dec}$ & 1555 & 74.9 & 84.5 & 9.6 & 74.9 & 76.60 & 1.70 & 1.70 & 18 \\
\hline $10 x$ & $10 \mathrm{Dec}$ & 1605 & 84.5 & 94.1 & 9.6 & 84.5 & 94.26 & 9.76 & 9.76 & 102 \\
\hline $11 x$ & $10 \mathrm{Dec}$ & 1650 & 94.1 & 103.7 & 9.6 & 94.1 & 104.16 & 10.06 & 10.06 & 105 \\
\hline $12 x$ & $10 \mathrm{Dec}$ & 1720 & 103.7 & 113.3 & 9.6 & 103.7 & 113.54 & 9.84 & 9.84 & 103 \\
\hline $13 x$ & $10 \mathrm{Dec}$ & 1745 & 113.3 & 122.9 & 9.6 & 113.3 & 122.45 & 9.15 & 9.15 & 95 \\
\hline $14 X$ & $10 \mathrm{Dec}$ & 1810 & 122.9 & 132.4 & 9.5 & 122.9 & 132.51 & 9.61 & 9.61 & 101 \\
\hline $15 X$ & $10 \mathrm{Dec}$ & 1840 & 132.4 & 142.0 & 9.6 & 132.4 & 142.07 & 9.67 & 9.67 & 101 \\
\hline $16 x$ & $10 \mathrm{Dec}$ & 1905 & 142.0 & 147.0 & 5.0 & 142.0 & 148.80 & 6.80 & 6.80 & 136 \\
\hline $17 X$ & $10 \mathrm{Dec}$ & 1935 & 147.0 & 156.6 & 9.6 & 147.0 & 156.78 & 9.78 & 9.78 & 102 \\
\hline $18 x$ & $10 \mathrm{Dec}$ & 2005 & 156.6 & 166.2 & 9.6 & 156.6 & 166.62 & 10.02 & 10.02 & 104 \\
\hline $19 x$ & $10 \mathrm{Dec}$ & 2035 & 166.2 & 175.8 & 9.6 & 166.2 & 175.86 & 9.66 & 9.66 & 101 \\
\hline $20 x$ & $10 \mathrm{Dec}$ & 2115 & 175.8 & 185.4 & 9.6 & 175.8 & 185.37 & 9.57 & 9.57 & 100 \\
\hline $21 x$ & $10 \mathrm{Dec}$ & 2150 & 185.4 & 194.9 & 9.5 & 185.4 & 194.93 & 9.53 & 9.53 & 100 \\
\hline $22 x$ & $10 \mathrm{Dec}$ & 2230 & 194.9 & 204.4 & 9.5 & 194.9 & 204.46 & 9.56 & 9.56 & 101 \\
\hline $23 x$ & $10 \mathrm{Dec}$ & 2300 & 204.4 & 214.0 & 9.6 & 204.4 & 214.09 & 9.69 & 9.69 & 101 \\
\hline $24 X$ & $10 \mathrm{Dec}$ & 2335 & 214.0 & 223.6 & 9.6 & 214.0 & 223.48 & 9.48 & 9.48 & 99 \\
\hline $25 x$ & $11 \mathrm{Dec}$ & 0025 & 223.6 & 233.1 & 9.5 & 223.6 & 232.6 & 9.00 & 9.00 & 95 \\
\hline $26 \mathrm{X}$ & $11 \mathrm{Dec}$ & 0110 & 233.1 & 242.7 & 9.6 & 233.1 & 242.74 & 9.64 & 9.64 & 100 \\
\hline $27 x$ & $11 \mathrm{Dec}$ & 0145 & 242.7 & 252.3 & 9.6 & 242.7 & 243.70 & 1.00 & 1.00 & 10 \\
\hline $28 \mathrm{X}$ & $11 \mathrm{Dec}$ & 0225 & 252.3 & 261.9 & 9.6 & 252.3 & 262.57 & 10.27 & 10.27 & 107 \\
\hline $29 x$ & $11 \mathrm{Dec}$ & 0305 & 261.9 & 271.5 & 9.6 & 261.9 & 271.78 & 9.88 & 9.88 & 103 \\
\hline $30 x$ & $11 \mathrm{Dec}$ & 0345 & 271.5 & 281.1 & 9.6 & 271.5 & 281.35 & 9.85 & 9.85 & 103 \\
\hline $31 x$ & $11 \mathrm{Dec}$ & 0425 & 281.1 & 290.7 & 9.6 & 281.1 & 290.87 & 9.77 & 9.77 & 102 \\
\hline $32 x$ & $11 \mathrm{Dec}$ & 0505 & 290.7 & 300.3 & 9.6 & 290.7 & 300.76 & 10.06 & 10.06 & 105 \\
\hline $33 x$ & $11 \mathrm{Dec}$ & 0550 & 300.3 & 309.5 & 9.2 & 300.3 & 310.17 & 9.87 & 9.87 & 107 \\
\hline $34 X$ & $11 \mathrm{Dec}$ & 0630 & 309.5 & 319.1 & 9.6 & 309.5 & 319.42 & 9.92 & 9.92 & 103 \\
\hline $35 x$ & $11 \mathrm{Dec}$ & 0710 & 319.1 & 328.7 & 9.6 & 319.1 & 328.97 & 9.87 & 9.87 & 103 \\
\hline $36 x$ & $11 \mathrm{Dec}$ & 0815 & 328.7 & 338.3 & 9.6 & 328.7 & 337.99 & 9.29 & 9.29 & 97 \\
\hline & & & & vanced total: & 338.3 & & & & & \\
\hline & & & Total in & terval cored: & 327.61 & & & & & \\
\hline $339-U 138$ & & & & & & & & & & \\
\hline $1 \mathrm{~W}$ & $12 \mathrm{Dec}$ & 0745 & & & $\star \star \star \star *$ Drilled & from 0 to 290. & m DSF without & t coring ${ }^{\star \star \star *}$ & & \\
\hline $2 \mathrm{R}$ & $12 \mathrm{Dec}$ & 0845 & 290.0 & 299.6 & 9.6 & 290.0 & 299.59 & 9.59 & 9.59 & 100 \\
\hline $3 R$ & $12 \mathrm{Dec}$ & 0945 & 299.6 & 309.2 & 9.6 & 299.6 & 308.36 & 8.76 & 8.76 & 91 \\
\hline $4 \mathrm{R}$ & $12 \mathrm{Dec}$ & 1045 & 309.2 & 318.8 & 9.6 & 309.2 & 309.20 & 0.00 & 0.00 & 0 \\
\hline $5 R$ & $12 \mathrm{Dec}$ & 1150 & 318.8 & 328.4 & 9.6 & 318.8 & 327.69 & 8.89 & 8.89 & 93 \\
\hline $6 \mathrm{R}$ & $12 \mathrm{Dec}$ & 1330 & 328.4 & 338.0 & 9.6 & 328.4 & 336.30 & 7.90 & 7.90 & 82 \\
\hline $7 \mathrm{R}$ & $12 \mathrm{Dec}$ & 1450 & 338.0 & 347.6 & 9.6 & 338.0 & 346.05 & 8.05 & 8.05 & 84 \\
\hline $8 \mathrm{R}$ & $12 \mathrm{Dec}$ & 1625 & 347.6 & 357.2 & 9.6 & 347.6 & 357.52 & 9.92 & 9.92 & 103 \\
\hline $9 \mathrm{R}$ & $12 \mathrm{Dec}$ & 1800 & 357.2 & 366.8 & 9.6 & 357.2 & 365.25 & 8.05 & 8.05 & 84 \\
\hline $10 \mathrm{R}$ & $12 \mathrm{Dec}$ & 1930 & 366.8 & 376.4 & 9.6 & 366.8 & 376.54 & 9.74 & 9.74 & 101 \\
\hline
\end{tabular}


Table T1 (continued).

\begin{tabular}{|c|c|c|c|c|c|c|c|c|c|c|}
\hline \multirow[b]{2}{*}{ Core } & \multirow[b]{2}{*}{$\begin{array}{l}\text { Date } \\
(2011)\end{array}$} & \multirow[b]{2}{*}{$\begin{array}{l}\text { Time } \\
(\mathrm{h})\end{array}$} & \multicolumn{2}{|c|}{ Depth DSF $(\mathrm{m})$} & \multirow[b]{2}{*}{$\begin{array}{c}\text { Interval } \\
\text { advanced (m) }\end{array}$} & \multicolumn{2}{|c|}{ Depth CSF $(\mathrm{m})$} & \multirow[b]{2}{*}{$\begin{array}{l}\text { Length of core } \\
\text { recovered }(m)\end{array}$} & \multirow[b]{2}{*}{$\begin{array}{l}\text { Curated } \\
\text { length }(m)\end{array}$} & \multirow[b]{2}{*}{$\begin{array}{c}\text { Recovery } \\
\text { (\%) }\end{array}$} \\
\hline & & & $\begin{array}{l}\text { Top of cored } \\
\text { interval }\end{array}$ & $\begin{array}{l}\text { Bottom of } \\
\text { cored interval }\end{array}$ & & $\begin{array}{c}\text { Top of } \\
\text { recovered core }\end{array}$ & $\begin{array}{l}\text { Bottom of } \\
\text { recovered core }\end{array}$ & & & \\
\hline $11 \mathrm{R}$ & $12 \mathrm{Dec}$ & 2100 & 376.4 & 386.0 & 9.6 & 376.4 & 386.13 & 9.73 & 9.73 & 101 \\
\hline $12 \mathrm{R}$ & $12 \mathrm{Dec}$ & 2220 & 386.0 & 395.6 & 9.6 & 386.0 & 395.46 & 9.46 & 9.46 & 99 \\
\hline $13 \mathrm{R}$ & $13 \mathrm{Dec}$ & 2355 & 395.6 & 405.2 & 9.6 & 395.6 & 404.91 & 9.31 & 9.31 & 97 \\
\hline $14 \mathrm{R}$ & $13 \mathrm{Dec}$ & 0120 & 405.2 & 414.8 & 9.6 & 405.2 & 410.68 & 5.48 & 5.48 & 57 \\
\hline $15 \mathrm{R}$ & $13 \mathrm{Dec}$ & 0240 & 414.8 & 424.3 & 9.5 & 414.8 & 422.98 & 8.18 & 8.18 & 86 \\
\hline $16 \mathrm{R}$ & $13 \mathrm{Dec}$ & 0355 & 424.3 & 433.9 & 9.6 & 424.3 & 430.69 & 6.39 & 6.39 & 67 \\
\hline $17 \mathrm{R}$ & $13 \mathrm{Dec}$ & 0500 & 433.9 & 443.4 & 9.5 & 433.9 & 436.86 & 2.96 & 2.96 & 31 \\
\hline $18 \mathrm{R}$ & $13 \mathrm{Dec}$ & 0615 & 443.4 & 453.0 & 9.6 & 443.4 & 452.62 & 9.22 & 9.22 & 96 \\
\hline $19 \mathrm{R}$ & $13 \mathrm{Dec}$ & 0800 & 453.0 & 462.6 & 9.6 & 453.0 & 458.59 & 5.59 & 5.59 & 58 \\
\hline $20 \mathrm{R}$ & $13 \mathrm{Dec}$ & 0950 & 462.6 & 472.2 & 9.6 & 462.6 & 472.36 & 9.76 & 9.76 & 102 \\
\hline $21 \mathrm{R}$ & $13 \mathrm{Dec}$ & 1100 & 472.2 & 481.8 & 9.6 & 472.2 & 479.42 & 7.22 & 7.22 & 75 \\
\hline $22 \mathrm{R}$ & $13 \mathrm{Dec}$ & 1230 & 481.8 & 491.4 & 9.6 & 481.8 & 489.75 & 7.95 & 7.95 & 83 \\
\hline $23 \mathrm{R}$ & $13 \mathrm{Dec}$ & 1400 & 491.4 & 501.0 & 9.6 & 491.4 & 499.84 & 8.44 & 8.44 & 88 \\
\hline $24 \mathrm{R}$ & $13 \mathrm{Dec}$ & 1525 & 501.0 & 510.6 & 9.6 & 501.0 & 510.15 & 9.15 & 9.15 & 95 \\
\hline $25 \mathrm{R}$ & $13 \mathrm{Dec}$ & 1705 & 510.6 & 519.9 & 9.3 & 510.6 & 520.25 & 9.65 & 9.65 & 104 \\
\hline $26 \mathrm{R}$ & $13 \mathrm{Dec}$ & 1825 & 519.9 & 529.5 & 9.6 & 519.9 & 527.96 & 8.06 & 8.06 & 84 \\
\hline $27 \mathrm{R}$ & $13 \mathrm{Dec}$ & 2005 & 529.5 & 539.1 & 9.6 & 529.5 & 539.45 & 9.95 & 9.95 & 104 \\
\hline $28 \mathrm{R}$ & $13 \mathrm{Dec}$ & 2125 & 539.1 & 548.7 & 9.6 & 539.1 & 545.85 & 6.75 & 6.75 & 70 \\
\hline $29 \mathrm{R}$ & $13 \mathrm{Dec}$ & 2300 & 548.7 & 558.3 & 9.6 & 548.7 & 558.61 & 9.91 & 9.91 & 103 \\
\hline $30 \mathrm{R}$ & $14 \mathrm{Dec}$ & 0025 & 558.3 & 567.9 & 9.6 & 558.3 & 564.88 & 6.58 & 6.58 & 69 \\
\hline $31 \mathrm{R}$ & $14 \mathrm{Dec}$ & 0205 & 567.9 & 577.5 & 9.6 & 567.9 & 573.59 & 5.69 & 5.69 & 59 \\
\hline $32 \mathrm{R}$ & $14 \mathrm{Dec}$ & 0405 & 577.5 & 587.1 & 9.6 & 577.5 & 586.28 & 8.78 & 8.78 & 91 \\
\hline $33 \mathrm{R}$ & $14 \mathrm{Dec}$ & 0535 & 587.1 & 596.7 & 9.6 & 587.1 & 597.01 & 9.91 & 9.91 & 103 \\
\hline $34 \mathrm{R}$ & $14 \mathrm{Dec}$ & 0735 & 596.7 & 606.3 & 9.6 & 596.7 & 603.82 & 7.12 & 7.12 & 74 \\
\hline $35 \mathrm{R}$ & $14 \mathrm{Dec}$ & 0945 & 606.3 & 615.9 & 9.6 & 606.3 & 616.30 & 10.00 & 10.00 & 104 \\
\hline $36 \mathrm{R}$ & $14 \mathrm{Dec}$ & 1100 & 615.9 & 625.5 & 9.6 & 615.9 & 619.86 & 3.96 & 3.96 & 41 \\
\hline $37 \mathrm{R}$ & $14 \mathrm{Dec}$ & 1300 & 625.5 & 635.1 & 9.6 & 625.5 & 634.54 & 9.04 & 9.04 & 94 \\
\hline $38 \mathrm{R}$ & $14 \mathrm{Dec}$ & 1425 & 635.1 & 644.7 & 9.6 & 635.1 & 643.59 & 8.49 & 8.49 & 88 \\
\hline $39 \mathrm{R}$ & $14 \mathrm{Dec}$ & 1525 & 644.7 & 654.3 & 9.6 & 644.7 & 650.36 & 5.66 & 5.66 & 59 \\
\hline $40 R$ & $14 \mathrm{Dec}$ & 1645 & 654.3 & 663.9 & 9.6 & 654.3 & 662.37 & 8.07 & 8.07 & 84 \\
\hline $41 \mathrm{R}$ & $14 \mathrm{Dec}$ & 1815 & 663.9 & 673.5 & 9.6 & 663.9 & 666.32 & 2.42 & 2.42 & 25 \\
\hline $42 \mathrm{R}$ & $14 \mathrm{Dec}$ & 2010 & 673.5 & 683.2 & 9.7 & 673.5 & 682.20 & 8.70 & 8.70 & 90 \\
\hline $43 R$ & $14 \mathrm{Dec}$ & 2110 & 683.2 & 692.9 & 9.7 & 683.2 & 686.02 & 2.82 & 2.82 & 29 \\
\hline $44 \mathrm{R}$ & $14 \mathrm{Dec}$ & 2220 & 692.9 & 702.5 & 9.6 & 692.9 & 693.66 & 0.76 & 0.76 & 8 \\
\hline $45 \mathrm{R}$ & $15 \mathrm{Dec}$ & 2350 & 702.5 & 712.0 & 9.5 & 702.5 & 703.39 & 0.89 & 0.89 & 9 \\
\hline $46 \mathrm{R}$ & $15 \mathrm{Dec}$ & 0105 & 712.0 & 721.6 & 9.6 & 712.0 & 712.30 & 0.30 & 0.30 & 3 \\
\hline $47 \mathrm{R}$ & $15 \mathrm{Dec}$ & 0220 & 721.6 & 731.2 & 9.6 & 721.6 & 722.09 & 0.49 & 0.49 & 5 \\
\hline $48 \mathrm{R}$ & $15 \mathrm{Dec}$ & 0445 & 731.2 & 740.8 & 9.6 & 731.2 & 737.50 & 6.30 & 6.30 & 66 \\
\hline $49 \mathrm{R}$ & $15 \mathrm{Dec}$ & 0630 & 740.8 & 750.4 & 9.6 & 740.8 & 748.19 & 7.39 & 7.39 & 77 \\
\hline $50 \mathrm{R}$ & $15 \mathrm{Dec}$ & 0815 & 750.4 & 760.0 & 9.6 & 750.4 & 752.48 & 2.08 & 2.08 & 22 \\
\hline $51 \mathrm{R}$ & $15 \mathrm{Dec}$ & 1025 & 760.0 & 769.6 & 9.6 & 760.0 & 765.74 & 5.74 & 5.74 & 60 \\
\hline $52 \mathrm{R}$ & $15 \mathrm{Dec}$ & 1205 & 769.6 & 779.2 & 9.6 & 769.6 & 772.98 & 3.38 & 3.38 & 35 \\
\hline $53 \mathrm{R}$ & $15 \mathrm{Dec}$ & 1435 & 779.2 & 788.8 & 9.6 & 779.2 & 786.70 & 7.50 & 7.50 & 78 \\
\hline $54 \mathrm{R}$ & $15 \mathrm{Dec}$ & 1640 & 788.8 & 798.4 & 9.6 & 788.8 & 792.81 & 4.01 & 4.01 & 42 \\
\hline $55 \mathrm{R}$ & $15 \mathrm{Dec}$ & 1930 & 798.4 & 808.0 & 9.6 & 798.4 & 805.68 & 7.28 & 7.28 & 76 \\
\hline $56 \mathrm{R}$ & $15 \mathrm{Dec}$ & 2145 & 808.0 & 817.6 & 9.6 & 808.0 & 817.18 & 9.18 & 9.18 & 96 \\
\hline $57 \mathrm{R}$ & $16 \mathrm{Dec}$ & 0020 & 817.6 & 827.2 & 9.6 & 817.6 & 824.63 & 7.03 & 7.03 & 73 \\
\hline $58 \mathrm{R}$ & $16 \mathrm{Dec}$ & 0230 & 827.2 & 836.8 & 9.6 & 827.2 & 834.38 & 7.18 & 7.18 & 75 \\
\hline $59 \mathrm{R}$ & $16 \mathrm{Dec}$ & 0440 & 836.8 & 846.4 & 9.6 & 836.8 & 845.61 & 8.81 & 8.81 & 92 \\
\hline $60 \mathrm{R}$ & $16 \mathrm{Dec}$ & 0600 & 846.4 & 856.0 & 9.6 & 846.4 & 846.43 & 0.03 & 0.03 & 0 \\
\hline $61 \mathrm{R}$ & $16 \mathrm{Dec}$ & 0800 & 856.0 & 865.6 & 9.6 & 856.0 & 865.85 & 9.85 & 9.85 & 103 \\
\hline \multirow[t]{3}{*}{$62 \mathrm{R}$} & $16 \mathrm{Dec}$ & 0910 & 865.6 & 870.0 & 4.4 & 865.6 & 865.60 & 0.00 & 0.00 & 0 \\
\hline & & & Ad & vanced total: & 870.0 & & & & & \\
\hline & \multicolumn{4}{|c|}{ Total interval cored: } & 413.66 & & & & & \\
\hline
\end{tabular}

$\mathrm{DRF}=$ drilling depth below rig floor, $\mathrm{DSF}=$ drilling depth below seafloor, CSF = core depth below seafloor. $\mathrm{H}=$ hydraulic piston coring system, $\mathrm{X}$ = extended core barrel system, $\mathrm{R}=$ rotary core barrel system, $\mathrm{W}=$ washed interval. Time is Universal Time Coordinated. 
Table T2. Lithology and number of beds, Site U1387. (Continued on next page.)

\begin{tabular}{|c|c|c|c|c|c|c|c|}
\hline \multirow[b]{2}{*}{ Core } & \multicolumn{3}{|c|}{ Number of beds } & \multicolumn{4}{|c|}{ Bed lithology (\%) } \\
\hline & Sandy & Silty mud & Dolostone & Sandy & Silty mud & Nannofossil mud & Dolostone \\
\hline \multicolumn{8}{|c|}{ 339-U1387A- } \\
\hline $1 \mathrm{H}$ & 2 & 2 & & 31 & 43 & 27 & \\
\hline $2 \mathrm{H}$ & 11 & 5 & & 31 & 31 & 38 & \\
\hline $3 \mathrm{H}$ & 10 & 11 & & 45 & 47 & 8 & \\
\hline $4 \mathrm{H}$ & 5 & 7 & & 11 & 22 & 67 & \\
\hline $5 \mathrm{H}$ & 6 & 5 & & 10 & 25 & 65 & \\
\hline $6 \mathrm{H}$ & 1 & 2 & & 1 & 21 & 78 & \\
\hline $7 X$ & 1 & 2 & & 3 & 35 & 62 & \\
\hline $8 \mathrm{X}$ & 8 & 7 & & 18 & 19 & 63 & \\
\hline $9 \mathrm{X}$ & 1 & 1 & & 2 & 1 & 98 & \\
\hline $10 x$ & 1 & 2 & & 3 & 3 & 94 & \\
\hline $11 x$ & 1 & 3 & & 3 & 40 & 58 & \\
\hline $12 \mathrm{X}$ & & & & 0 & 0 & 100 & \\
\hline $13 x$ & & & & 0 & 0 & 100 & \\
\hline $14 \mathrm{X}$ & 1 & 4 & & 2 & 16 & 82 & \\
\hline $15 X$ & & 3 & & 0 & 11 & 89 & \\
\hline $16 X$ & 1 & 2 & & 11 & 8 & 81 & \\
\hline $17 X$ & 1 & & & 10 & 0 & 90 & \\
\hline $18 X$ & & & & 0 & 0 & 100 & \\
\hline $19 \mathrm{X}$ & 2 & 1 & & 6 & 7 & 86 & \\
\hline $20 x$ & 4 & 4 & & 3 & 22 & 75 & \\
\hline $21 x$ & 3 & 5 & & 7 & 5 & 88 & \\
\hline $22 x$ & 6 & 15 & & 10 & 12 & 78 & \\
\hline $23 x$ & 2 & 4 & & 9 & 22 & 69 & \\
\hline $24 X$ & 3 & 10 & & 6 & 36 & 58 & \\
\hline $25 x$ & 2 & 3 & & 4 & 39 & 58 & \\
\hline $26 \mathrm{X}$ & 4 & 5 & & 20 & 26 & 54 & \\
\hline $27 X$ & 2 & 5 & & 7 & 11 & 82 & \\
\hline $28 \mathrm{X}$ & 1 & 3 & & 1 & 11 & 88 & \\
\hline $29 X$ & 2 & 5 & & 9 & 18 & 74 & \\
\hline $30 x$ & 1 & 3 & & 4 & 7 & 88 & \\
\hline $31 x$ & 1 & & & 4 & 0 & 96 & \\
\hline $32 x$ & 1 & 6 & & 1 & 19 & 80 & \\
\hline $33 x$ & 2 & 4 & & 6 & 7 & 86 & \\
\hline $34 X$ & & 4 & & 0 & 35 & 65 & \\
\hline $35 \mathrm{X}$ & & 1 & & 0 & 16 & 84 & \\
\hline $36 x$ & 1 & 3 & & 5 & 27 & 68 & \\
\hline $37 x$ & 1 & 2 & & 3 & 8 & 89 & \\
\hline $38 x$ & 1 & 2 & & 0 & 10 & 90 & \\
\hline \multicolumn{8}{|c|}{ 339-U1387B- } \\
\hline $1 \mathrm{H}$ & 5 & 8 & & 7 & 25 & 68 & \\
\hline $2 \mathrm{H}$ & 11 & 17 & & 13 & 43 & 44 & \\
\hline $3 \mathrm{H}$ & 7 & 12 & & 18 & 26 & 56 & \\
\hline $4 \mathrm{H}$ & 5 & 10 & & 13 & 24 & 64 & \\
\hline $5 \mathrm{H}$ & & 5 & & 0 & 8 & 92 & \\
\hline $6 \mathrm{X}$ & 3 & 6 & & 2 & 22 & 76 & \\
\hline $7 X$ & 2 & 5 & & 10 & 10 & 80 & \\
\hline $8 \mathrm{X}$ & 2 & 10 & & 2 & 39 & 60 & \\
\hline $9 \mathrm{X}$ & 1 & 2 & & 1 & 7 & 92 & \\
\hline $10 x$ & 5 & 10 & & 7 & 29 & 64 & \\
\hline $11 x$ & 3 & 4 & & 6 & 9 & 86 & \\
\hline $12 \mathrm{X}$ & & 2 & & 0 & 21 & 79 & \\
\hline $13 x$ & 2 & 8 & & 7 & 27 & 66 & \\
\hline $14 \mathrm{X}$ & & 1 & & 0 & 9 & 91 & \\
\hline $15 X$ & & 1 & & 0 & 1 & 99 & \\
\hline $16 \mathrm{X}$ & & 1 & & 0 & 6 & 94 & \\
\hline $17 X$ & & & & 0 & 0 & 100 & \\
\hline $18 \mathrm{X}$ & & 2 & & 0 & 4 & 96 & \\
\hline $19 x$ & & 5 & & 0 & 21 & 79 & \\
\hline $20 x$ & & 5 & & 0 & 11 & 89 & \\
\hline $21 x$ & & 6 & & 0 & 26 & 74 & \\
\hline $22 x$ & 1 & 3 & & 1 & 56 & 44 & \\
\hline $23 x$ & & 2 & & 0 & 8 & 92 & \\
\hline $24 X$ & 1 & 1 & & 2 & 2 & 97 & \\
\hline $25 X$ & 2 & 5 & & 7 & 14 & 79 & \\
\hline $26 X$ & 2 & 4 & & 0 & 14 & 86 & \\
\hline $27 X$ & & & & Disturbed & & & \\
\hline $28 \mathrm{X}$ & 2 & 7 & & 3 & 30 & 67 & \\
\hline $29 x$ & 5 & 9 & & 21 & 25 & 54 & \\
\hline
\end{tabular}


Table T2 (continued).

\begin{tabular}{|c|c|c|c|c|c|c|c|}
\hline \multirow[b]{2}{*}{ Core } & \multicolumn{3}{|c|}{ Number of beds } & \multicolumn{4}{|c|}{ Bed lithology (\%) } \\
\hline & Sandy & Silty mud & Dolostone & Sandy & Silty mud & Nannofossil mud & Dolostone \\
\hline $30 x$ & 1 & 5 & & 2 & 11 & 87 & \\
\hline $31 x$ & 5 & 7 & & 17 & 24 & 58 & \\
\hline $32 x$ & 1 & 6 & & 5 & 24 & 71 & \\
\hline $33 x$ & & 1 & & 0 & 20 & 80 & \\
\hline $34 X$ & 1 & 3 & & 3 & 15 & 82 & \\
\hline $35 x$ & & 4 & & 0 & 15 & 85 & \\
\hline $36 x$ & & 3 & & 0 & 7 & 93 & \\
\hline \multicolumn{8}{|c|}{ 339-U1387C- } \\
\hline $1 \mathrm{~W}$ & & & & 0 & 0 & 100 & \\
\hline $2 \mathrm{R}$ & 3 & 2 & & 6 & 3 & 92 & \\
\hline $3 \mathrm{R}$ & 1 & 2 & & 1 & 22 & 77 & \\
\hline $5 \mathrm{R}$ & 1 & & & 5 & 0 & 95 & \\
\hline $6 \mathrm{R}$ & & & & 0 & 0 & 100 & \\
\hline $7 R$ & 1 & 4 & & 5 & 16 & 79 & \\
\hline $8 \mathrm{R}$ & 4 & 7 & & 7 & 8 & 85 & \\
\hline $9 \mathrm{R}$ & & 1 & & 0 & 60 & 40 & \\
\hline $10 \mathrm{R}$ & 3 & 7 & & 8 & 35 & 56 & \\
\hline $11 \mathrm{R}$ & 3 & 6 & & 18 & 39 & 43 & \\
\hline $12 \mathrm{R}$ & 2 & 4 & & 8 & 10 & 83 & \\
\hline $13 \mathrm{R}$ & 4 & 7 & & 9 & 44 & 48 & \\
\hline $14 \mathrm{R}$ & 3 & 4 & & 16 & 28 & 56 & \\
\hline $15 \mathrm{R}$ & 1 & 3 & & 0 & 21 & 79 & \\
\hline $16 \mathrm{R}$ & 1 & 1 & & 5 & 6 & 89 & \\
\hline $17 \mathrm{R}$ & 1 & 2 & & 40 & 18 & 42 & \\
\hline $18 \mathrm{R}$ & 2 & 5 & & 2 & 7 & 91 & \\
\hline $19 \mathrm{R}$ & 3 & 1 & 1 & 3 & 0 & 86 & 11 \\
\hline $20 \mathrm{R}$ & 6 & & 1 & 8 & 0 & 92 & 1 \\
\hline $21 \mathrm{R}$ & & 4 & & 0 & 4 & 96 & \\
\hline $22 \mathrm{R}$ & & 3 & & 0 & 15 & 85 & \\
\hline $23 \mathrm{R}$ & 3 & 4 & & 4 & 17 & 79 & \\
\hline $24 \mathrm{R}$ & 3 & 4 & & 2 & 14 & 84 & \\
\hline $25 \mathrm{R}$ & 3 & 5 & & 4 & 8 & 87 & \\
\hline $26 \mathrm{R}$ & 1 & 4 & & 1 & 15 & 84 & \\
\hline $27 \mathrm{R}$ & 4 & 6 & & 4 & 5 & 91 & \\
\hline $28 \mathrm{R}$ & 2 & 4 & & 5 & 3 & 92 & \\
\hline $29 \mathrm{R}$ & 2 & 5 & & 1 & 7 & 93 & \\
\hline $30 \mathrm{R}$ & 4 & & & 7 & 0 & 93 & \\
\hline $31 R$ & 2 & 2 & & 2 & 3 & 95 & \\
\hline $32 \mathrm{R}$ & 3 & & & 3 & 0 & 97 & \\
\hline $33 \mathrm{R}$ & 1 & 4 & & 1 & 6 & 93 & \\
\hline $34 \mathrm{R}$ & & & & 0 & 0 & 100 & \\
\hline $35 \mathrm{R}$ & 2 & 4 & & 0 & 7 & 92 & \\
\hline $36 \mathrm{R}$ & & 2 & & 0 & 11 & 89 & \\
\hline $37 R$ & 16 & 10 & & 24 & 15 & 60 & \\
\hline $38 \mathrm{R}$ & 22 & 16 & & 20 & 15 & 65 & \\
\hline $39 R$ & 11 & 5 & & 49 & 8 & 42 & \\
\hline $40 \mathrm{R}$ & 4 & 4 & & 17 & 6 & 77 & \\
\hline $41 R$ & 1 & 4 & & 6 & 87 & 6 & \\
\hline $42 \mathrm{R}$ & 3 & 11 & & 9 & 58 & 33 & \\
\hline $43 \mathrm{R}$ & 1 & 1 & & 7 & 53 & 40 & \\
\hline $44 \mathrm{R}$ & 3 & 2 & & 74 & 26 & 0 & \\
\hline $45 \mathrm{R}$ & 1 & & & 100 & 0 & 0 & \\
\hline $46 \mathrm{R}$ & 1 & & & 100 & 0 & 0 & \\
\hline $47 R$ & 1 & 1 & & 73 & 27 & 0 & \\
\hline $48 \mathrm{R}$ & & 7 & & 0 & 15 & 85 & \\
\hline $49 \mathrm{R}$ & 3 & 1 & & 14 & 1 & 85 & \\
\hline $50 \mathrm{R}$ & 3 & 3 & & 27 & 45 & 28 & \\
\hline $51 \mathrm{R}$ & 1 & 1 & & 1 & 1 & 98 & \\
\hline $52 \mathrm{R}$ & 1 & 2 & & 1 & 36 & 64 & \\
\hline $53 \mathrm{R}$ & & 1 & & 0 & 0 & 100 & \\
\hline $54 \mathrm{R}$ & 1 & 4 & & 0 & 15 & 85 & \\
\hline $55 \mathrm{R}$ & & 2 & & 0 & 24 & 76 & \\
\hline $56 \mathrm{R}$ & & & & 0 & 0 & 100 & \\
\hline $57 R$ & & & & 0 & 0 & 100 & \\
\hline $58 \mathrm{R}$ & & & & 0 & 0 & 100 & \\
\hline $59 \mathrm{R}$ & & & & 0 & 0 & 100 & \\
\hline $60 \mathrm{R}$ & & & & 0 & 0 & 100 & \\
\hline $61 \mathrm{R}$ & & & & 0 & 0 & 100 & \\
\hline
\end{tabular}




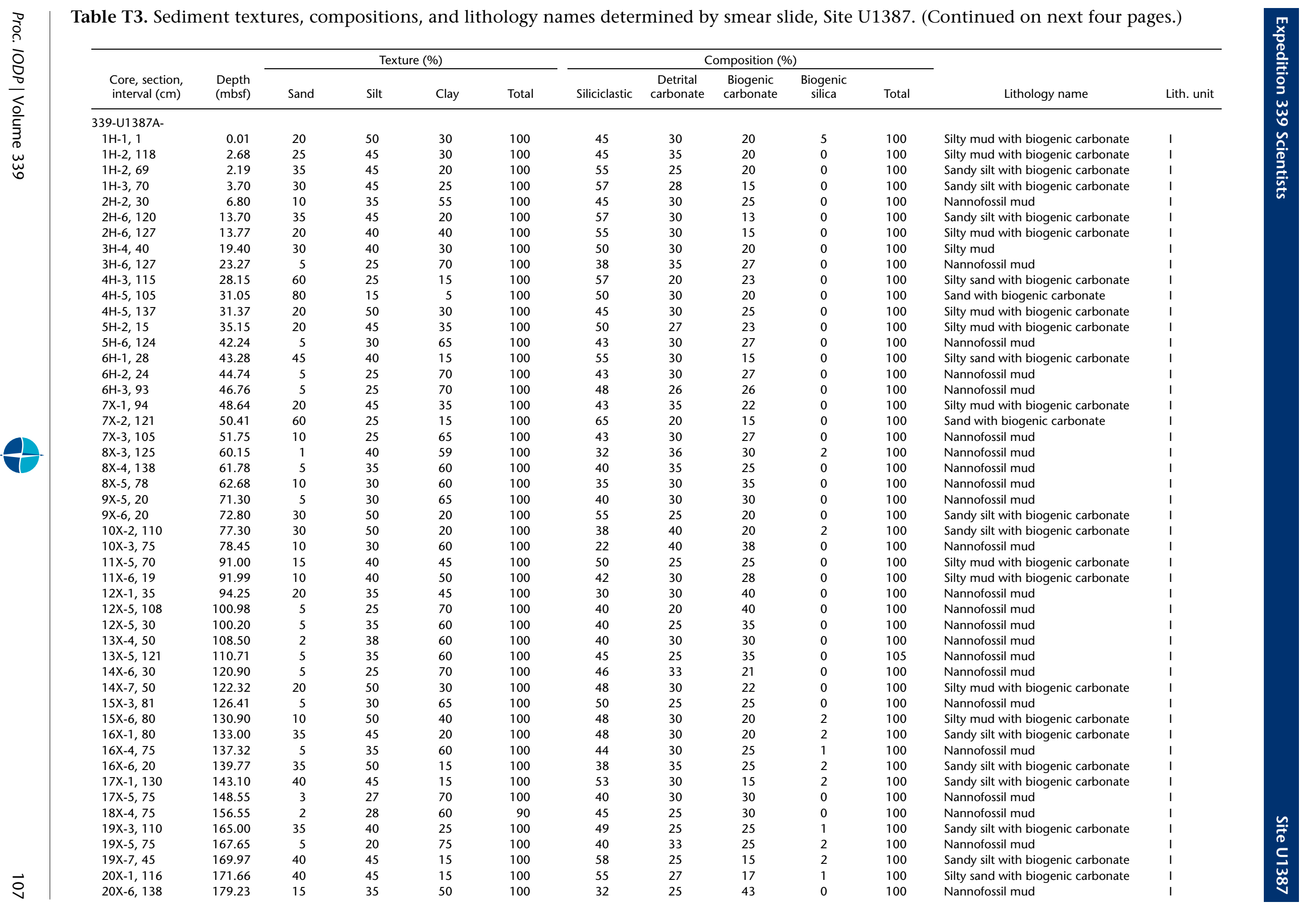


궁 Table T3 (continued). (Continued on next page.)

\begin{tabular}{|c|c|c|c|c|c|c|c|c|c|c|c|c|}
\hline \multirow[b]{2}{*}{$\begin{array}{l}\text { Core, section, } \\
\text { interval }(\mathrm{cm})\end{array}$} & \multirow[b]{2}{*}{$\begin{array}{l}\text { Depth } \\
\text { (mbsf) }\end{array}$} & \multicolumn{4}{|c|}{ Texture (\%) } & \multicolumn{5}{|c|}{ Composition (\%) } & \multirow[b]{2}{*}{ Lithology name } & \multirow[b]{2}{*}{ Lith. unit } \\
\hline & & Sand & Silt & Clay & Total & Siliciclastic & $\begin{array}{l}\text { Detrital } \\
\text { carbonate }\end{array}$ & $\begin{array}{l}\text { Biogenic } \\
\text { carbonate }\end{array}$ & $\begin{array}{l}\text { Biogenic } \\
\text { silica }\end{array}$ & Total & & \\
\hline $21 X-2,94$ & 182.54 & 10 & 25 & 65 & 100 & 23 & 27 & 49 & 1 & 100 & Nannofossil mud & I \\
\hline $21 X-4,94$ & 185.54 & 45 & 35 & 20 & 100 & 41 & 19 & 40 & 0 & 100 & Calcareous silty sand & 1 \\
\hline $22 X-4,60$ & 193.62 & 10 & 25 & 65 & 100 & 71 & 15 & 14 & 0 & 100 & Mud with biogenic carbonate & 1 \\
\hline $22 \mathrm{X}-5,113$ & 195.65 & 50 & 40 & 10 & 100 & 45 & 35 & 20 & 0 & 100 & Silty sand with biogenic carbonate & I \\
\hline $22 X-6,121$ & 197.23 & 60 & 30 & 10 & 100 & 38 & 27 & 35 & 0 & 100 & Calcareous silty sand & 1 \\
\hline $23 X-3,147$ & 203.67 & 50 & 35 & 15 & 100 & 65 & 20 & 15 & 0 & 100 & Silty sand with biogenic carbonate & I \\
\hline $23 X-5,70$ & 205.90 & 10 & 30 & 60 & 100 & 53 & 22 & 25 & 0 & 100 & Nannofossil mud & 1 \\
\hline $24 X-3,110$ & 211.84 & 20 & 50 & 30 & 100 & 60 & 20 & 20 & 0 & 100 & Silty mud with biogenic carbonate & 1 \\
\hline $24 X-7,70$ & 217.44 & 50 & 35 & 15 & 100 & 70 & 20 & 10 & 0 & 100 & Silty sand with biogenic carbonate & I \\
\hline $25 X-3,10$ & 221.50 & 20 & 50 & 30 & 100 & 60 & 25 & 15 & 0 & 100 & Silty mud with biogenic carbonate & 1 \\
\hline $25 X-5,73$ & 225.13 & 5 & 30 & 65 & 100 & 43 & 27 & 30 & 0 & 100 & Nannofossil mud & 1 \\
\hline $25 X-5,90$ & 225.30 & 5 & 35 & 60 & 100 & 50 & 30 & 20 & 0 & 100 & Mud with biogenic carbonate & 1 \\
\hline $26 \mathrm{X}-3,100$ & 232.00 & 0 & 30 & 70 & 100 & 45 & 25 & 30 & 0 & 100 & Nannofossil mud & 1 \\
\hline $26 X-6,60$ & 236.10 & 30 & 40 & 30 & 100 & 50 & 30 & 20 & 0 & 100 & Sandy silt with biogenic carbonate & I \\
\hline $27 X-1,140$ & 239.00 & 35 & 45 & 20 & 100 & 38 & 35 & 25 & 2 & 100 & Sandy silt with biogenic carbonate & 1 \\
\hline $27 X-4,70$ & 242.80 & 0 & 25 & 75 & 100 & 45 & 30 & 25 & 0 & 100 & Nannofossil mud & 1 \\
\hline $28 X-2,43$ & 249.13 & 35 & 45 & 20 & 100 & 43 & 30 & 25 & 2 & 100 & Sandy silt with biogenic carbonate & 1 \\
\hline $28 X-4,73$ & 252.43 & 5 & 25 & 70 & 100 & 50 & 20 & 30 & 0 & 100 & Nannofossil mud & 1 \\
\hline $29 X-5,110$ & 262.85 & 2 & 30 & 68 & 100 & 42 & 28 & 30 & 0 & 100 & Nannofossil mud & 1 \\
\hline $29 X-7,85$ & 265.60 & 50 & 30 & 20 & 100 & 60 & 25 & 15 & 0 & 100 & Silty sand with biogenic carbonate & 1 \\
\hline $30 X-3,60$ & 270.00 & 15 & 30 & 55 & 100 & 45 & 35 & 20 & 0 & 100 & Silty mud with biogenic carbonate & 1 \\
\hline $30 X-6,70$ & 274.60 & 5 & 40 & 55 & 100 & 43 & 30 & 27 & 0 & 100 & Nannofossil mud & 1 \\
\hline $31 X-5,75$ & 282.75 & 5 & 45 & 50 & 100 & 50 & 25 & 25 & 0 & 100 & Nannofossil mud & 1 \\
\hline $31 X-6,114$ & 284.23 & 30 & 45 & 25 & 100 & 50 & 28 & 20 & 2 & 100 & Sandy silt with biogenic carbonate & 1 \\
\hline $32 X-3,115$ & 289.75 & 5 & 40 & 55 & 100 & 49 & 25 & 25 & 1 & 100 & Nannofossil mud & 1 \\
\hline $32 X-3,8$ & 288.68 & 30 & 50 & 20 & 100 & 50 & 30 & 20 & 0 & 100 & Sandy silt with biogenic carbonate & 1 \\
\hline $33 X-5,73$ & 301.93 & 3 & 37 & 60 & 100 & 50 & 30 & 20 & 0 & 100 & Nannofossil mud & 1 \\
\hline $33 X-6,80$ & 303.50 & 60 & 25 & 15 & 100 & 70 & 15 & 15 & 0 & 100 & Silty sand with biogenic carbonate & 1 \\
\hline $35 X-4,33$ & 318.83 & 3 & 37 & 60 & 100 & 50 & 25 & 25 & 0 & 100 & Nannofossil mud & 1 \\
\hline $35 X-5,100$ & 321.00 & 5 & 55 & 40 & 100 & 53 & 25 & 20 & 2 & 100 & Silty mud with biogenic carbonate & I \\
\hline $36 X-2,81$ & 324.85 & 5 & 55 & 40 & 100 & 50 & 35 & 25 & 0 & 110 & Nannofossil silty mud & I \\
\hline $36 \mathrm{X}-5,90$ & 329.44 & 50 & 30 & 20 & 100 & 48 & 30 & 20 & 2 & 100 & Silty sand with biogenic carbonate & 1 \\
\hline $37 X-3,80$ & 337.00 & 5 & 25 & 70 & 100 & 40 & 30 & 30 & 0 & 100 & Nannofossil mud & 1 \\
\hline $37 X-6,60$ & 341.30 & 15 & 40 & 45 & 100 & 45 & 33 & 22 & 0 & 100 & Silty mud with biogenic carbonate & 1 \\
\hline $38 X-2,94$ & 345.23 & 2 & 28 & 70 & 100 & 50 & 20 & 30 & 0 & 100 & Nannofossil mud & 1 \\
\hline $38 \mathrm{X}-3,117$ & 346.96 & 20 & 45 & 35 & 100 & 42 & 33 & 22 & 3 & 100 & Silty mud with biogenic carbonate & 1 \\
\hline \multicolumn{13}{|l|}{ 339-U1387B- } \\
\hline $1 \mathrm{H}-2,65$ & 2.15 & 80 & 15 & 5 & 100 & 75 & 13 & 12 & 0 & 100 & Sand with biogenic carbonate & 1 \\
\hline $3 \mathrm{H}-3,103$ & 22.43 & 65 & 20 & 15 & 100 & 60 & 25 & 10 & 5 & 100 & Silty sand with biogenic carbonate & 1 \\
\hline $3 \mathrm{H}-3,37$ & 21.77 & 60 & 25 & 15 & 100 & 63 & 25 & 10 & 2 & 100 & Silty sand with biogenic carbonate & 1 \\
\hline $11 X-6,19$ & 101.58 & 10 & 35 & 55 & 100 & 50 & 30 & 20 & 0 & 100 & Silty mud with biogenic carbonate & 1 \\
\hline $14 X-2,108$ & 125.48 & 20 & 50 & 30 & 100 & 45 & 35 & 20 & 0 & 100 & Silty mud with biogenic carbonate & 1 \\
\hline $14 X-5,80$ & 129.70 & 5 & 45 & 50 & 100 & 50 & 30 & 20 & 0 & 100 & Silty mud with biogenic carbonate & 1 \\
\hline $16 X-1,20$ & 142.20 & 30 & 40 & 30 & 100 & 62 & 20 & 15 & 3 & 100 & Silty mud with biogenic carbonate & 1 \\
\hline $16 X-3,75$ & 145.75 & 18 & 48 & 34 & 100 & 48 & 30 & 20 & 2 & 100 & Silty mud with biogenic carbonate & 1 \\
\hline 18X-3, 91 & 159.31 & 20 & 50 & 30 & 100 & 53 & 25 & 20 & 2 & 100 & Silty mud with biogenic carbonate & 1 \\
\hline $18 X-6,75$ & 163.65 & 2 & 38 & 60 & 100 & 45 & 30 & 25 & 0 & 100 & Nannofossil mud & 1 \\
\hline $20 X-3,64$ & 179.44 & 2 & 38 & 60 & 100 & 50 & 30 & 20 & 0 & 100 & Mud with biogenic carbonate & 1 \\
\hline $20 X-5,66$ & 182.46 & 30 & 30 & 40 & 100 & 60 & 25 & 15 & 0 & 100 & Silty mud with biogenic carbonate & 1 \\
\hline $22 X-2,25$ & 196.65 & 20 & 45 & 35 & 100 & 45 & 30 & 25 & 0 & 100 & Nannofossil silty mud & 1 \\
\hline
\end{tabular}




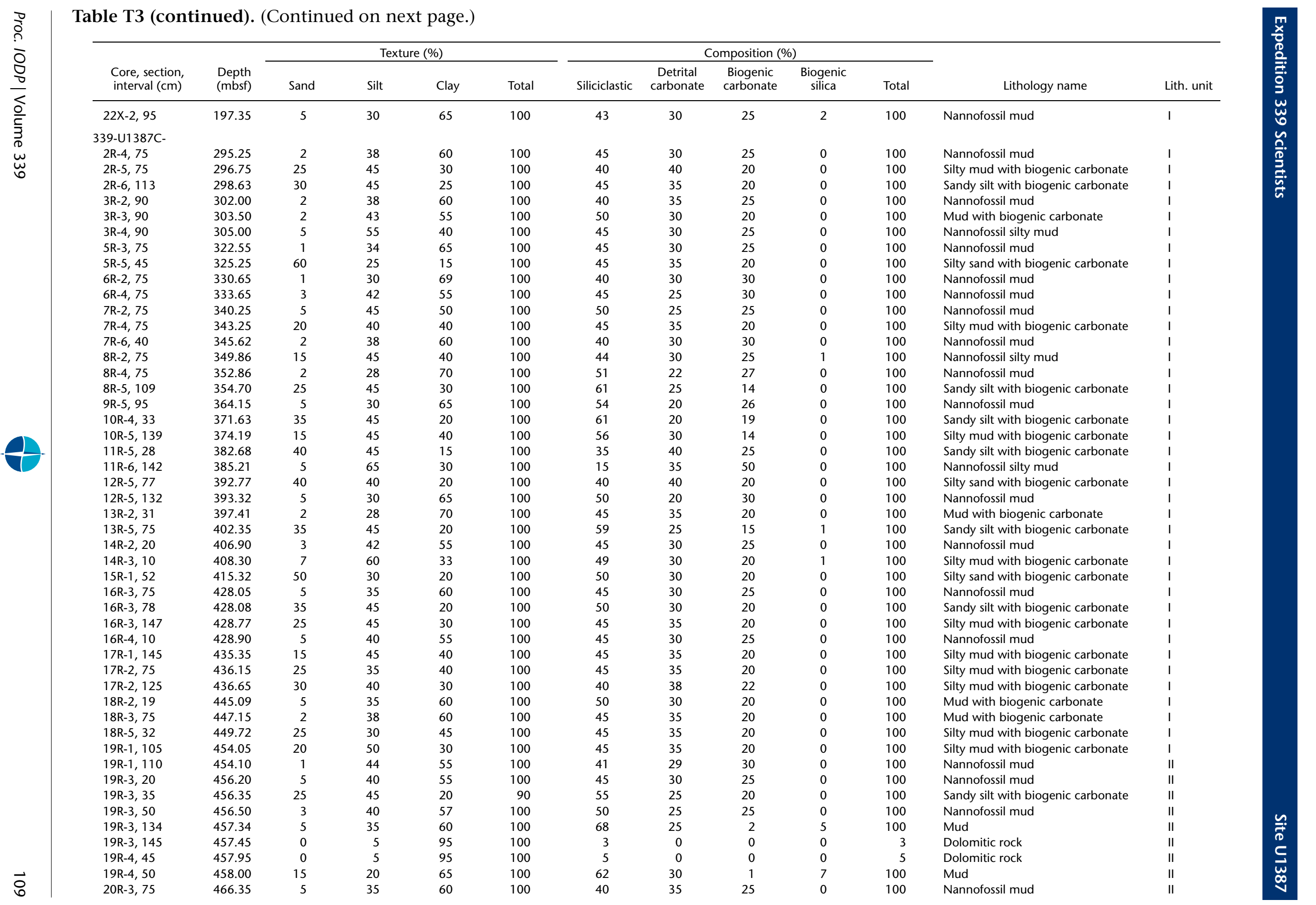




\begin{tabular}{|c|c|c|c|c|c|c|c|c|c|c|c|c|}
\hline \multirow[b]{2}{*}{$\begin{array}{l}\text { Core, section, } \\
\text { interval }(\mathrm{cm})\end{array}$} & \multirow[b]{2}{*}{$\begin{array}{l}\text { Depth } \\
\text { (mbsf) }\end{array}$} & \multicolumn{4}{|c|}{ Texture (\%) } & \multicolumn{5}{|c|}{ Composition (\%) } & \multirow[b]{2}{*}{ Lithology name } & \multirow[b]{2}{*}{ Lith. unit } \\
\hline & & Sand & Silt & Clay & Total & Siliciclastic & $\begin{array}{c}\text { Detrital } \\
\text { carbonate }\end{array}$ & $\begin{array}{c}\text { Biogenic } \\
\text { carbonate }\end{array}$ & $\begin{array}{l}\text { Biogenic } \\
\text { silica }\end{array}$ & Total & & \\
\hline $21 \mathrm{R}-1,72$ & 472.92 & 25 & 45 & 30 & 100 & 50 & 30 & 20 & 0 & 100 & Silty mud with biogenic carbonate & ॥ \\
\hline $21 \mathrm{R}-3,75$ & 475.95 & 0 & 35 & 65 & 100 & 40 & 30 & 30 & 0 & 100 & Nannofossil mud & ॥ \\
\hline $22 \mathrm{R}-1,96$ & 482.76 & 20 & 50 & 30 & 100 & 60 & 20 & 20 & 0 & 100 & Silty mud with biogenic carbonate & ॥ \\
\hline $22 \mathrm{R}-1,112$ & 482.92 & 35 & 30 & 35 & 100 & 40 & 35 & 25 & 0 & 100 & Nannofossil sandy mud & ॥ \\
\hline $22 \mathrm{R}-4,75$ & 487.05 & 0 & 30 & 70 & 100 & 40 & 30 & 30 & 0 & 100 & Nannofossil mud & ॥ \\
\hline $22 \mathrm{R}-4,110$ & 487.40 & 5 & 25 & 70 & 100 & 50 & 24 & 26 & 0 & 100 & Nannofossil mud & ॥ \\
\hline $23 \mathrm{R}-3,120$ & 495.60 & 5 & 40 & 55 & 100 & 30 & 30 & 40 & 0 & 100 & Nannofossil mud & ॥ \\
\hline $23 \mathrm{R}-4,38$ & 496.28 & 55 & 30 & 15 & 100 & 35 & 35 & 30 & 0 & 100 & Calcareous silty sand & ॥ \\
\hline $23 R-4,50$ & 496.40 & 50 & 30 & 20 & 100 & 40 & 30 & 28 & 2 & 100 & Calcareous silty sand & ॥ \\
\hline $23 R-4,80$ & 496.70 & 5 & 30 & 65 & 100 & 60 & 15 & 20 & 5 & 100 & Calcareous mud & ॥ \\
\hline $23 \mathrm{R}-4,108$ & 496.98 & 55 & 25 & 20 & 100 & 38 & 29 & 28 & 5 & 100 & Calcareous silty sand & ॥ \\
\hline $24 \mathrm{R}-3,50$ & 504.50 & 5 & 45 & 50 & 100 & 40 & 35 & 25 & 0 & 100 & Calcareous mud & II \\
\hline $24 R-6,66$ & 509.16 & 50 & 35 & 15 & 100 & 20 & 30 & 50 & 0 & 100 & Calcareous silty sand & ॥ \\
\hline $25 \mathrm{R}-7,25$ & 519.67 & 5 & 36 & 60 & 101 & 50 & 20 & 27 & 3 & 100 & Nannofossil mud & ॥ \\
\hline $25 \mathrm{R}-7,70$ & 520.12 & 5 & 40 & 55 & 100 & 27 & 25 & 48 & 0 & 100 & Nannofossil mud & ॥ \\
\hline $26 \mathrm{R}-6,3$ & 527.13 & 3 & 37 & 60 & 100 & 50 & 22 & 25 & 3 & 100 & Nannofossil mud & II \\
\hline $26 \mathrm{R}-6,72$ & 527.82 & 15 & 25 & 60 & 100 & 55 & 17 & 15 & 3 & 90 & Mud with biogenic carbonate & ॥ \\
\hline $27 R-5,47$ & 535.97 & 45 & 35 & 20 & 100 & 55 & 30 & 15 & 0 & 100 & Silty sand with biogenic carbonate & II \\
\hline $27 R-5,55$ & 536.05 & 20 & 40 & 40 & 100 & 45 & 30 & 25 & 0 & 100 & Nannofossil mud & ॥ \\
\hline $28 \mathrm{R}-4,90$ & 544.50 & 0 & 20 & 80 & 100 & 35 & 15 & 50 & 0 & 100 & Muddy nannofossil ooze & ॥ \\
\hline $29 \mathrm{R}-5,10$ & 554.80 & 5 & 45 & 50 & 100 & 40 & 30 & 30 & 0 & 100 & Nannofossil mud & ॥ \\
\hline $29 \mathrm{R}-5,43$ & 555.13 & 65 & 20 & 15 & 100 & 55 & 30 & 15 & 0 & 100 & Silty sand with biogenic carbonate & II \\
\hline $29 \mathrm{R}-5,55$ & 555.25 & 10 & 40 & 50 & 100 & 49 & 30 & 20 & 1 & 100 & Nannofossil mud & II \\
\hline $29 \mathrm{R}-5,135$ & 556.05 & 10 & 30 & 60 & 100 & 47 & 25 & 25 & 3 & 100 & Nannofossil mud & ॥ \\
\hline $30 \mathrm{R}-4,5$ & 562.85 & 5 & 25 & 70 & 100 & 45 & 30 & 25 & 0 & 100 & Nannofossil mud & ॥ \\
\hline $30 \mathrm{R}-4,27$ & 563.07 & 25 & 45 & 30 & 100 & 45 & 30 & 25 & 0 & 100 & Nannofossil silty mud & ॥ \\
\hline $30 \mathrm{R}-4,40$ & 563.20 & 0 & 40 & 60 & 100 & 40 & 30 & 30 & 0 & 100 & Nannofossil mud & ॥ \\
\hline $31 \mathrm{R}-1,86$ & 568.76 & 60 & 20 & 20 & 100 & 55 & 30 & 15 & 0 & 100 & Silty sand with biogenic carbonate & ॥ \\
\hline $31 \mathrm{R}-1,99$ & 568.89 & 0 & 45 & 55 & 100 & 40 & 30 & 30 & 0 & 100 & Nannofossil mud & ॥ \\
\hline $32 \mathrm{R}-2,140$ & 580.40 & 3 & 45 & 52 & 100 & 45 & 30 & 25 & 0 & 100 & Nannofossil mud & ॥ \\
\hline $32 \mathrm{R}-3,10$ & 580.60 & 35 & 30 & 35 & 100 & 45 & 30 & 25 & 0 & 100 & Nannofossil sandy mud & ॥ \\
\hline $32 \mathrm{R}-3,18$ & 580.68 & 2 & 38 & 60 & 100 & 50 & 25 & 25 & 0 & 100 & Nannofossil mud & II \\
\hline $32 \mathrm{R}-5,30$ & 583.80 & 3 & 27 & 70 & 100 & 40 & 30 & 30 & 0 & 100 & Nannofossil mud & II \\
\hline $32 \mathrm{R}-5,57$ & 584.07 & 40 & 40 & 20 & 100 & 45 & 35 & 20 & 0 & 100 & Silty sand with biogenic carbonate & ॥ \\
\hline $32 \mathrm{R}-5,75$ & 584.25 & 3 & 37 & 60 & 100 & 58 & 20 & 20 & 2 & 100 & Mud with biogenic carbonate & II \\
\hline $33 R-5,30$ & 593.40 & 15 & 45 & 40 & 100 & 40 & 35 & 25 & 0 & 100 & Nannofossil silty mud & ॥ \\
\hline $33 R-5,35$ & 593.45 & 3 & 37 & 60 & 100 & 35 & 30 & 35 & 0 & 100 & Nannofossil mud & ॥ \\
\hline $35 R-5,10$ & 612.40 & 3 & 37 & 60 & 100 & 40 & 30 & 30 & 0 & 100 & Nannofossil mud & III \\
\hline $35 \mathrm{R}-5,47$ & 612.77 & 40 & 30 & 30 & 100 & 45 & 35 & 20 & 0 & 100 & Sandy mud with biogenic carbonate & III \\
\hline $35 R-5,60$ & 612.90 & 2 & 33 & 65 & 100 & 40 & 35 & 25 & 0 & 100 & Nannofossil mud & IIII \\
\hline $37 R-3,50$ & 629.00 & 5 & 25 & 70 & 100 & 62 & 18 & 20 & 0 & 100 & Mud with biogenic carbonate & III \\
\hline $37 R-3,110$ & 629.60 & 3 & 27 & 70 & 100 & 50 & 20 & 30 & 0 & 100 & Nannofossil mud & III \\
\hline $38 \mathrm{R}-2,15$ & 636.75 & 10 & 35 & 55 & 100 & 60 & 15 & 25 & 0 & 100 & Nannofossil mud & III \\
\hline $38 \mathrm{R}-2,18$ & 636.78 & 3 & 27 & 70 & 100 & 45 & 20 & 35 & 0 & 100 & Nannofossil mud & III \\
\hline $38 \mathrm{R}-3,78$ & 638.88 & 3 & 37 & 60 & 100 & 50 & 25 & 25 & 0 & 100 & Nannofossil mud & III \\
\hline $38 \mathrm{R}-3,100$ & 639.10 & 10 & 45 & 45 & 100 & 40 & 35 & 25 & 0 & 100 & Nannofossil silty mud & III \\
\hline $38 \mathrm{R}-3,130$ & 639.40 & 5 & 40 & 55 & 100 & 40 & 30 & 50 & 0 & 120 & Nannofossil mud & III \\
\hline $40 \mathrm{R}-4,30$ & 659.10 & 5 & 35 & 60 & 100 & 45 & 35 & 20 & 0 & 100 & Mud with biogenic carbonate & III \\
\hline $42 \mathrm{R}-6,90$ & 681.90 & 55 & 30 & 15 & 100 & 50 & 30 & 20 & 0 & 100 & Silty sand with biogenic carbonate & IIII \\
\hline $48 \mathrm{R}-2,40$ & 733.10 & 5 & 35 & 60 & 100 & 45 & 30 & 25 & 0 & 100 & Nannofossil mud & III \\
\hline
\end{tabular}

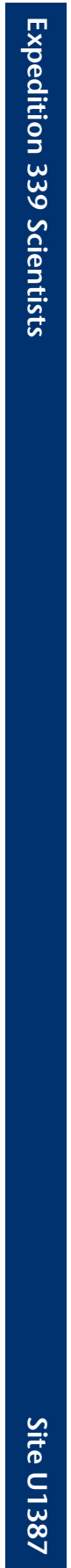




\begin{tabular}{|c|c|c|c|c|c|c|c|c|c|c|c|c|}
\hline \multirow[b]{2}{*}{$\begin{array}{l}\text { Core, section, } \\
\text { interval }(\mathrm{cm})\end{array}$} & \multirow[b]{2}{*}{$\begin{array}{l}\text { Depth } \\
\text { (mbsf) }\end{array}$} & \multicolumn{4}{|c|}{ Texture (\%) } & \multicolumn{5}{|c|}{ Composition (\%) } & \multirow[b]{2}{*}{ Lithology name } & \multirow[b]{2}{*}{ Lith. unit } \\
\hline & & Sand & Silt & Clay & Total & Siliciclastic & $\begin{array}{l}\text { Detrital } \\
\text { carbonate }\end{array}$ & $\begin{array}{l}\text { Biogenic } \\
\text { carbonate }\end{array}$ & $\begin{array}{l}\text { Biogenic } \\
\text { silica }\end{array}$ & Total & & \\
\hline $48 \mathrm{R}-4,35$ & 736.05 & 7 & 33 & 60 & 100 & 40 & 25 & 35 & 0 & 100 & Nannofossil mud & IIII \\
\hline $48 \mathrm{R}-4,82$ & 736.52 & 50 & 20 & 30 & 100 & 50 & 30 & 20 & 0 & 100 & Silty sand with biogenic carbonate & III \\
\hline $49 \mathrm{R}-4,100$ & 746.30 & 2 & 28 & 70 & 100 & 30 & 20 & 50 & 0 & 100 & Muddy nannofossil ooze & III \\
\hline $49 \mathrm{R}-5,30$ & 747.10 & 40 & 30 & 30 & 100 & 45 & 30 & 25 & 0 & 100 & Nannofossil sandy mud & III \\
\hline $51 \mathrm{R}-3,100$ & 763.64 & 40 & 30 & 30 & 100 & 50 & 25 & 25 & 0 & 100 & Nannofossil sandy mud & IV \\
\hline $53 \mathrm{R}-3,75$ & 782.78 & 2 & 38 & 60 & 100 & 50 & 20 & 30 & 0 & 100 & Nannofossil mud & IV \\
\hline $54 \mathrm{R}-3,50$ & 792.23 & 5 & 30 & 65 & 100 & 60 & 15 & 25 & 0 & 100 & Nannofossil mud & IV \\
\hline $55 \mathrm{R}-3,50$ & 801.90 & 15 & 40 & 45 & 100 & 70 & 15 & 15 & 0 & 100 & Silty mud with biogenic carbonate & IV \\
\hline $55 R-5,35$ & 804.75 & 5 & 30 & 65 & 100 & 60 & 15 & 25 & 0 & 100 & Nannofossil mud & IV \\
\hline 56R-1, 111 & 809.11 & 5 & 30 & 65 & 100 & 50 & 20 & 30 & 0 & 100 & Nannofossil mud & IV \\
\hline $56 \mathrm{R}-5,20$ & 814.20 & 5 & 30 & 65 & 100 & 50 & 20 & 30 & 0 & 100 & Nannofossil mud & IV \\
\hline $57 R-4,10$ & 822.23 & 5 & 30 & 65 & 100 & 55 & 15 & 30 & 0 & 100 & Nannofossil mud & IV \\
\hline $59 \mathrm{R}-3,24$ & 840.04 & 0 & 25 & 75 & 100 & 30 & 20 & 50 & 0 & 100 & Muddy nannofossil ooze & IV \\
\hline $59 \mathrm{R}-3,110$ & 840.90 & 0 & 20 & 80 & 100 & 30 & 20 & 50 & 0 & 100 & Clayey nannofossil ooze & IV \\
\hline $59 \mathrm{R}-3,145$ & 841.25 & 2 & 28 & 70 & 100 & 25 & 20 & 55 & 0 & 100 & Muddy nannofossil ooze & IV \\
\hline $61 \mathrm{R}-6,5$ & 863.57 & 0 & 25 & 75 & 100 & 20 & 20 & 60 & 0 & 100 & Muddy nannofossil ooze & IV \\
\hline $61 \mathrm{R}-6,110$ & 864.62 & 1 & 24 & 75 & 100 & 20 & 30 & 50 & 0 & 100 & Muddy nannofossil ooze & IV \\
\hline $61 \mathrm{R}-\mathrm{CC}, 5$ & 865.74 & 0 & 25 & 75 & 100 & 30 & 20 & 50 & 0 & 100 & Muddy nannofossil ooze & IV \\
\hline
\end{tabular}

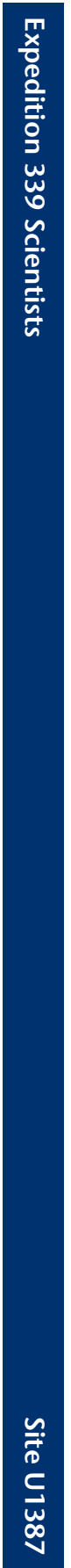




\begin{tabular}{|c|c|c|c|c|c|c|c|c|c|c|c|c|c|c|c|}
\hline $\begin{array}{l}\text { Core, section, } \\
\text { interval }(\mathrm{cm})\end{array}$ & $\begin{array}{l}\text { Depth } \\
\text { (mbsf) }\end{array}$ & $\begin{array}{c}\text { Total } \\
\text { intensity } \\
\text { (counts) }\end{array}$ & $\begin{array}{c}\text { Quartz } \\
\text { (counts) }\end{array}$ & $\begin{array}{l}\text { Calcite } \\
\text { (counts) }\end{array}$ & $\begin{array}{l}\text { K-feldspar } \\
\text { (counts) }\end{array}$ & $\begin{array}{l}\text { Plagioclase } \\
\text { (counts) }\end{array}$ & $\begin{array}{l}\text { Dolomite } \\
\text { (counts) }\end{array}$ & $\begin{array}{l}\text { Chlorite } \\
\text { (counts) }\end{array}$ & $\begin{array}{l}\text { Kaolinite } \\
\text { (counts) }\end{array}$ & $\begin{array}{c}\text { Illite } \\
\text { (counts) }\end{array}$ & $\begin{array}{l}\text { Smectite } \\
\text { (counts) }\end{array}$ & $\begin{array}{l}\text { Hornblende } \\
\text { (counts) }\end{array}$ & $\begin{array}{l}\text { Augite } \\
\text { (counts) }\end{array}$ & $\begin{array}{c}\text { Pyrite } \\
\text { (counts) }\end{array}$ & $\begin{array}{c}\text { Aragonite } \\
\text { (counts) }\end{array}$ \\
\hline \multicolumn{16}{|l|}{$339-$} \\
\hline U1387A-1H-4, 69-70 & 4.72 & 80,565 & 29,677 & 16,120 & 1,108 & 3,216 & 9,490 & 1,764 & 3,196 & 15,254 & 336 & 404 & NA & NA & NA \\
\hline U1387A-2H-6, 134-135 & 13.84 & 54,618 & 32,164 & 12,257 & NA & 1,460 & 3,020 & 615 & 1,114 & 2,995 & 263 & 159 & NA & NA & 571 \\
\hline U1387A-3H-6, 127-128 & 23.27 & 58,459 & 22,408 & 14,780 & 671 & 1,710 & 2,665 & 1,695 & 3,332 & 10,451 & 531 & 216 & NA & NA & NA \\
\hline U1387A-4H-5, 136-137 & 31.36 & 73,682 & 38,780 & 13,809 & 1,597 & 2,223 & 4,493 & 1,113 & 2,080 & 8,478 & 152 & 301 & 656 & NA & NA \\
\hline U1387A-5H-6, 0-1 & 41.00 & 43,000 & 19,215 & 13,145 & 481 & 1,037 & 1,371 & 723 & 1,397 & 4,484 & 431 & 151 & 565 & NA & NA \\
\hline U1387A-6H-3, 93-94 & 46.76 & 59,757 & 29,583 & 10,017 & 911 & 2,353 & 2,942 & 1,553 & 2,400 & 8,588 & 466 & 275 & 669 & NA & NA \\
\hline U1387A-7X-2, 134-135 & 50.54 & 62,998 & 27,065 & 16,008 & 872 & 2,562 & 5,407 & 1,194 & 1,968 & 6,598 & 476 & 286 & NA & NA & 562 \\
\hline U1387A-8X-5, 78-79 & 62.68 & 49,455 & 23,462 & 14,862 & 561 & 1,398 & 2,016 & 689 & 1,503 & 4,160 & 290 & 76 & NA & 438 & NA \\
\hline U1387A-9X-5, 131-132 & 72.41 & 58,313 & 25,980 & 13,778 & 5,071 & 1,407 & 3,058 & 897 & 1,563 & 5,323 & 390 & 133 & 713 & NA & NA \\
\hline U1387A-11X-6, 100-101 & 92.80 & 53,869 & 24,361 & 19,543 & 428 & 1,777 & 1,432 & 690 & 1,490 & 3,575 & 398 & 175 & NA & NA & NA \\
\hline U1387A-12X-6, 121-122 & 102.61 & 38,105 & 14,872 & 12,818 & 554 & 898 & 1,393 & 455 & 1,211 & 3,179 & 409 & 115 & 480 & 1,721 & NA \\
\hline U1387A-13X-6, 102-103 & 112.02 & 50,713 & 23,511 & 14,632 & 448 & 1,154 & 2,286 & 863 & 1,644 & 4,867 & 301 & 417 & 590 & NA & NA \\
\hline U1387A-14X-6, 105-106 & 121.65 & 48,219 & 25,048 & 14,232 & 518 & 1,100 & 1,054 & 664 & 1,141 & 2,651 & 440 & 110 & 455 & 302 & 504 \\
\hline U1387A-15X-6, 115-116 & 131.25 & 57,612 & 31,453 & 14,370 & NA & 2,862 & 2,034 & 782 & 1,377 & 3,582 & 209 & 291 & NA & NA & 652 \\
\hline U1387A-16X-6, 135-136 & 140.92 & 42,101 & 18,301 & 14,087 & 411 & 1,059 & 1,381 & 731 & 1,406 & 3,221 & 438 & NA & 496 & 570 & NA \\
\hline U1387A-17X-6, 100-100 & 150.30 & 44,638 & 20,310 & 13,085 & 440 & 1,184 & 2,311 & 705 & 1,677 & 3,422 & 528 & 38 & 547 & 391 & NA \\
\hline U1387A-18X-6, 48-49 & 158.80 & 47,923 & 25,543 & 12,802 & 552 & 1,928 & 1,264 & 532 & 1,250 & 2,806 & 409 & 254 & 583 & NA & NA \\
\hline U1387A-19X-6, 103-104 & 169.43 & 59,190 & 29,998 & 17,008 & 535 & 1,757 & 2,603 & 821 & 1,750 & 3,259 & 473 & 137 & NA & NA & 849 \\
\hline U1387A-20X-6, 137-138 & 179.22 & 52,797 & 27,157 & 11,261 & 933 & 2,132 & 3,470 & 829 & 1,691 & 3,959 & 343 & 145 & 877 & NA & NA \\
\hline U1387A-21X-6, 92-93 & 188.52 & 51,648 & 28,741 & 13,045 & 410 & 1,147 & 2,242 & 605 & 1,196 & 2,702 & 301 & 169 & 587 & NA & 503 \\
\hline U1387A-22X-6, 135-136 & 197.37 & 51,212 & 19,525 & 17,151 & 479 & 1,320 & 2,748 & 1,106 & 2,215 & 5,560 & 511 & 152 & NA & NA & 445 \\
\hline U1387A-23X-6, 109-110 & 207.79 & 52,478 & 26,250 & 14,937 & NA & 1,304 & 3,119 & 741 & 1,669 & 3,215 & 365 & 232 & NA & NA & 646 \\
\hline U1387A-24X-6, 136-137 & 216.60 & 55,071 & 22,833 & 14,358 & 597 & 3,171 & 2,375 & 1,242 & 2,268 & 6,992 & 600 & 169 & NA & 466 & NA \\
\hline U1387A-25X-6, 111-112 & 227.01 & 75,246 & 35,182 & 13,877 & 1,136 & 3,279 & 8,211 & 1,471 & 2,543 & 8,778 & 534 & 235 & NA & NA & NA \\
\hline U1387A-26X-6, 110-111 & 236.60 & 47,463 & 20,458 & 14,000 & 532 & 1,883 & 1,229 & 1,003 & 1,976 & 4,398 & 686 & 192 & 582 & 524 & NA \\
\hline U1387A-27X-6, 93-94 & 246.03 & 68,810 & 34,202 & 10,108 & 948 & 3,862 & 4,151 & 1,645 & 2,554 & 9,833 & 586 & 354 & 567 & NA & NA \\
\hline U1387A-28X-6, 98-99 & 255.68 & 56,034 & 29,565 & 8,985 & 1,003 & 2,675 & 1,405 & 1,356 & 2,086 & 6,905 & 448 & 782 & 626 & 198 & NA \\
\hline U1387A-29X-6, 137-138 & 264.62 & 93,926 & 51,267 & 17,199 & 2,048 & 3,734 & 9,258 & 1,191 & 2,077 & 5,209 & 276 & 649 & NA & NA & 1,018 \\
\hline U1387A-30X-6, 110-111 & 275.00 & 55,151 & 26,427 & 11,607 & 595 & 1,751 & 2,467 & 1,541 & 2,606 & 6,707 & 796 & 135 & NA & 519 & NA \\
\hline U1387A-31X-6, 94-95 & 284.03 & 54,777 & 29,151 & 11,071 & 949 & 1,687 & 2,688 & 1,219 & 2,343 & 4,960 & 485 & 224 & NA & NA & NA \\
\hline U1387A-32X-6, 110-111 & 294.20 & 58,431 & 37,164 & 9,873 & 877 & 1,948 & 1,468 & 779 & 1,452 & 3,501 & 317 & 434 & 618 & NA & NA \\
\hline U1387A-33X-6, 137-138 & 304.07 & 63,147 & 38,365 & 13,755 & 995 & 1,840 & 1,948 & 867 & 1,713 & 3,133 & 433 & 97 & NA & NA & NA \\
\hline U1387A-34X-6, 137-138 & 313.41 & 52,280 & 23,380 & 10,467 & 1,258 & 1,405 & 2,921 & 1,298 & 2,327 & 7,324 & 582 & 226 & 672 & 420 & NA \\
\hline U1387A-35X-6, 104-105 & 322.54 & 66,003 & 33,228 & 13,917 & 706 & 2,387 & 3,945 & 1,436 & 2,618 & 6,111 & 581 & 359 & NA & NA & 715 \\
\hline U1387A-36X-6, 140-141 & 331.44 & 61,219 & 31,042 & 16,405 & 931 & 1,475 & 2,520 & 1,272 & 2,170 & 4,785 & 380 & 239 & NA & NA & NA \\
\hline U1387A-37X-6, 98-99 & 341.68 & 60,585 & 33,229 & 14,601 & 446 & 2,411 & 3,006 & 834 & 1,683 & 3,179 & 414 & 170 & NA & NA & 612 \\
\hline U1387A-38X-6, 130-131 & 351.59 & 58,782 & 35,766 & 9,141 & 723 & 2,079 & 2,049 & 930 & 1,647 & 5,211 & 436 & 136 & 664 & NA & NA \\
\hline U1387C-8R-6, 137-138 & 356.48 & 47,450 & 24,265 & 11,938 & 551 & 1,579 & 2,573 & 821 & 1,655 & 3,000 & 499 & 81 & 488 & NA & NA \\
\hline U1387C-9R-5, 110-111 & 364.30 & 61,209 & 27,691 & 13,375 & 703 & 2,552 & 3,682 & 1,558 & 2,696 & 7,830 & 567 & 162 & NA & 393 & NA \\
\hline U1387C-10R-5, 139-140 & 374.19 & 60,819 & 25,957 & 12,410 & 1,729 & 4,126 & 7,291 & 996 & 2,269 & 4,497 & 549 & 70 & NA & NA & 925 \\
\hline U1387C-11R-6, 142-143 & 385.21 & 79,764 & 31,920 & 12,686 & 1,419 & 2,082 & 15,686 & 1,898 & 3,852 & 8,383 & 650 & 475 & NA & NA & 713 \\
\hline U1387C-12R-5, 132-133 & 393.32 & 61,225 & 23,513 & 11,524 & 1,204 & 1,984 & 5,378 & 1,726 & 2,538 & 11,925 & 595 & 203 & 635 & NA & NA \\
\hline U1387C-13R-6, 89-90 & 403.99 & 48,611 & 24,157 & 14,621 & NA & 1,049 & 2,453 & 759 & 1,819 & 2,892 & 436 & NA & NA & 425 & NA \\
\hline U1387C-14R-4, 70-71 & 410.40 & 96,758 & 64,348 & 8,858 & 925 & 6,902 & 4,093 & 1,275 & 2,072 & 6,830 & 351 & 315 & 547 & 242 & NA \\
\hline U1387C-15R-5, 127-128 & 422.07 & 51,474 & 24,360 & 15,648 & NA & 1,327 & 3,422 & 751 & 1,559 & 3,430 & 549 & 57 & NA & 371 & NA \\
\hline U1387C-16R-5, 59-60 & 430.49 & 53,774 & 21,069 & 13,566 & 712 & 1,409 & 3,696 & 1,424 & 2,818 & 7,683 & 867 & NA & NA & 530 & NA \\
\hline U1387C-18R-6, 88-89 & 451.78 & 50,818 & 22,450 & 12,340 & 694 & 1,418 & 1,915 & 1,286 & 2,298 & 6,713 & 639 & 38 & 577 & 450 & NA \\
\hline U1387C-19R-4, 39-41 & 457.89 & 47,736 & 7,351 & NA & 185 & 563 & 38,364 & NA & 171 & 999 & 71 & 31 & NA & NA & NA \\
\hline U1387C-19R-4, 90-91 & 458.40 & 46,726 & 30,172 & 7,394 & 704 & 1,572 & 2,358 & NA & 732 & 2,698 & 484 & 107 & 505 & NA & NA \\
\hline
\end{tabular}


Table T4 (continued).

\begin{tabular}{|c|c|c|c|c|c|c|c|c|c|c|c|c|c|c|c|}
\hline $\begin{array}{l}\text { Core, section, } \\
\text { interval }(\mathrm{cm})\end{array}$ & $\begin{array}{l}\text { Depth } \\
\text { (mbsf) }\end{array}$ & $\begin{array}{c}\text { Total } \\
\text { intensity } \\
\text { (counts) }\end{array}$ & $\begin{array}{c}\text { Quartz } \\
\text { (counts) }\end{array}$ & $\begin{array}{c}\text { Calcite } \\
\text { (counts) }\end{array}$ & $\begin{array}{l}\text { K-feldspar } \\
\text { (counts) }\end{array}$ & $\begin{array}{l}\text { Plagioclase } \\
\text { (counts) }\end{array}$ & $\begin{array}{l}\text { Dolomite } \\
\text { (counts) }\end{array}$ & $\begin{array}{l}\text { Chlorite } \\
\text { (counts) }\end{array}$ & $\begin{array}{l}\text { Kaolinite } \\
\text { (counts) }\end{array}$ & $\begin{array}{c}\text { Illite } \\
\text { (counts) }\end{array}$ & $\begin{array}{l}\text { Smectite } \\
\text { (counts) }\end{array}$ & $\begin{array}{l}\text { Hornblende } \\
\text { (counts) }\end{array}$ & $\begin{array}{c}\text { Augite } \\
\text { (counts) }\end{array}$ & $\begin{array}{c}\text { Pyrite } \\
\text { (counts) }\end{array}$ & $\begin{array}{l}\text { Aragonite } \\
\text { (counts) }\end{array}$ \\
\hline U1387C-20R-6, 140-141 & 471.50 & 48,340 & 21,450 & 13,358 & 718 & 1,399 & 1,627 & 829 & 1,301 & 5,324 & 697 & 53 & 493 & 1,091 & NA \\
\hline U1387C-21R-5, 92-93 & 479.12 & 51,581 & 26,146 & 18,506 & 400 & 1,748 & 871 & 520 & 1,185 & 1,779 & 392 & 34 & NA & NA & NA \\
\hline U1387C-22R-6, 39-40 & 489.40 & 55,967 & 28,273 & 16,545 & 573 & 1,507 & 2,401 & 869 & 1,674 & 3,477 & 600 & 48 & NA & NA & NA \\
\hline U1387C-23R-5, 97-98 & 498.37 & 43,440 & 21,846 & 14,261 & 414 & 846 & 1,039 & 380 & 667 & 2,894 & 598 & NA & 495 & NA & NA \\
\hline U1387C-24R-6, 101-102 & 509.51 & 45,721 & 22,591 & 15,635 & 449 & 1,400 & 418 & NA & 810 & 3,305 & 440 & NA & 498 & 175 & NA \\
\hline U1387C-25R-5, 140-141 & 518.00 & 47,369 & 19,220 & 15,064 & 624 & 1,270 & 1,949 & 704 & 843 & 5,585 & 759 & NA & 519 & 832 & NA \\
\hline U1387C-26R-6, 46-47 & 527.56 & 43,397 & 18,507 & 18,861 & 469 & 1,199 & 530 & 281 & 642 & 1,972 & 516 & 48 & NA & 372 & NA \\
\hline U1387C-27R-6, 69-70 & 537.69 & 40,440 & 18,665 & 16,172 & 434 & 767 & 575 & 418 & 919 & 1,869 & 570 & 50 & NA & NA & NA \\
\hline U1387C-28R-4, 123-125 & 544.83 & 41,577 & 18,667 & 16,176 & 425 & 955 & 581 & 333 & 760 & 2,165 & 429 & 40 & 459 & 587 & NA \\
\hline U1387C-29R-5, 107-108 & 555.77 & 43,112 & 19,712 & 14,518 & 470 & 1,282 & 1,060 & NA & 777 & 3,032 & 723 & 62 & 557 & 919 & NA \\
\hline U1387C-30R-5, 55-56 & 564.60 & 47,335 & 23,364 & 17,124 & 336 & 1,348 & 752 & 550 & 1,301 & 1,923 & 586 & 51 & NA & NA & NA \\
\hline U1387C-30R-5, 58-59 & 564.63 & 45,730 & 23,550 & 16,254 & 477 & 912 & 946 & NA & 984 & 1,987 & 419 & 47 & NA & 154 & NA \\
\hline U1387C-31R-4, 107-108 & 573.47 & 55,554 & 27,527 & 17,671 & 472 & 1,413 & 1,115 & 962 & 1,813 & 3,925 & 645 & 10 & NA & NA & NA \\
\hline U1387C-32R-6, 91-92 & 585.91 & 51,217 & 17,864 & 14,194 & 1,717 & 1,707 & 1,309 & 1,344 & 1,584 & 9,675 & 1,066 & 75 & 574 & 108 & NA \\
\hline U1387C-33R-6, 134-135 & 595.94 & 40,343 & 17,698 & 12,081 & 510 & 1,134 & 978 & 598 & 715 & 3,503 & 677 & NA & 442 & 2,007 & NA \\
\hline U1387C-34R-5, 79-80 & 603.49 & 47,159 & 24,006 & 12,407 & 696 & 1,688 & 1,488 & 578 & 883 & 4,113 & 628 & 79 & 593 & NA & NA \\
\hline U1387C-35R-1, 137-138 & 607.67 & 50,581 & 20,943 & 15,754 & 615 & 1,677 & 1,596 & 933 & 1,379 & 6,185 & 816 & 153 & 530 & NA & NA \\
\hline U1387C-36R-3, 78-79 & 619.68 & 62,536 & 26,148 & 17,561 & 847 & 1,867 & 1,704 & 1,604 & 3,716 & 7,565 & 770 & 47 & NA & 706 & NA \\
\hline U1387C-37R-4, 54-56 & 630.54 & 43,981 & 19,001 & 17,881 & NA & 1,002 & 673 & 597 & 1,267 & 2,444 & 743 & NA & NA & 373 & NA \\
\hline U1387C-38R-4, 124-125 & 640.84 & 41,890 & 17,364 & 18,327 & 387 & 613 & 1,338 & 384 & 643 & 1,484 & 468 & NA & NA & 882 & NA \\
\hline U1387C-39R-4, 69-70 & 649.89 & 56,092 & 30,801 & 15,497 & 852 & 1,342 & 2,697 & 453 & 667 & 2,376 & 622 & NA & 432 & 353 & NA \\
\hline U1387C-40R-5, 87-89 & 661.17 & 66,369 & 45,566 & 10,718 & 620 & 2,019 & 1,439 & 452 & 737 & 3,844 & 382 & 55 & 537 & NA & NA \\
\hline U1387C-41R-1, 130-131 & 665.20 & 47,349 & 20,485 & 18,914 & 1,390 & 776 & 2,085 & NA & 1,155 & 1,968 & 576 & NA & NA & NA & NA \\
\hline U1387C-42R-5, 139-140 & 680.89 & 46,795 & 18,931 & 22,063 & 270 & 697 & 1,058 & 414 & 824 & 1,702 & 672 & NA & NA & 164 & NA \\
\hline U1387C-43R-2, 71-72 & 685.39 & 56,862 & 29,428 & 14,092 & 865 & 1,688 & 3,903 & 450 & 676 & 4,338 & 679 & 45 & NA & 698 & NA \\
\hline U1387C-44R-1, 37-38 & 693.27 & 59,104 & 15,382 & 39,623 & 2,128 & 560 & 240 & NA & 70 & 384 & 97 & NA & NA & 229 & 392 \\
\hline U1387C-45R-1, 76-77 & 703.26 & 208,689 & 85,395 & 89,414 & 24,979 & 5,913 & 1,520 & NA & NA & 1,298 & 170 & NA & NA & NA & NA \\
\hline U1387C-47R-1, 37-38 & 721.97 & 68,209 & 34,851 & 15,329 & 4,545 & 1,143 & 8,827 & 265 & 787 & 1,401 & 372 & 63 & NA & NA & 626 \\
\hline U1387C-48R-5, 49-50 & 737.30 & 55,383 & 29,241 & 19,330 & 1,131 & 970 & 1,234 & NA & 1,080 & 1,823 & 574 & NA & NA & NA & NA \\
\hline U1387C-49R-5, 121-122 & 748.01 & 65,656 & 35,651 & 19,901 & 1,627 & 1,199 & 1,627 & 392 & 835 & 3,084 & 633 & 84 & NA & NA & 623 \\
\hline U1387C-50R-2, 71-72 & 752.30 & 59,259 & 29,899 & 20,435 & 1,018 & 1,444 & 1,462 & 590 & 1,517 & 2,242 & 568 & 84 & NA & NA & NA \\
\hline U1387C-51R-4, 53-54 & 764.55 & 47,423 & 23,482 & 17,450 & NA & 816 & 948 & 573 & 1,152 & 2,108 & 758 & 136 & NA & NA & NA \\
\hline U1387C-52R-3, 74-75 & 772.81 & 50,444 & 23,637 & 14,785 & 2,145 & 3,962 & 1,012 & NA & 594 & 2,307 & 818 & 68 & 471 & 645 & NA \\
\hline U1387C-53R-6, 57-58 & 786.57 & 46,671 & 20,831 & 18,146 & 485 & 606 & 1,146 & 586 & 1,462 & 2,530 & 762 & 117 & NA & NA & NA \\
\hline U1387C-54R-3, 96-97 & 792.69 & 48,557 & 25,272 & 17,070 & NA & 719 & 777 & 589 & 1,330 & 1,788 & 658 & NA & NA & 354 & NA \\
\hline U1387C-55R-4, 134-135 & 804.24 & 49,121 & 25,844 & 15,043 & 577 & 1,319 & 1,007 & 688 & 1,935 & 2,004 & 617 & 87 & NA & NA & NA \\
\hline U1387C-56R-5, 131-132 & 815.31 & 46,020 & 23,301 & 15,153 & 407 & 680 & 2,235 & 420 & 1,540 & 1,398 & 764 & 122 & NA & NA & NA \\
\hline U1387C-57R-4, 125-126 & 823.38 & 47,214 & 23,878 & 15,602 & 340 & 962 & 767 & 738 & 1,949 & 2,370 & 608 & NA & NA & NA & NA \\
\hline U1387C-58R-4, 131-132 & 833.01 & 39,999 & 16,800 & 18,289 & NA & 584 & 562 & 346 & 977 & 1,614 & 515 & 84 & NA & 228 & NA \\
\hline U1387C-59R-6, 106-107 & 845.36 & 38,126 & 15,077 & 17,726 & 301 & 493 & 620 & 312 & 1,133 & 1,616 & 681 & NA & NA & 167 & NA \\
\hline U1387C-61R-5, 132-133 & 863.33 & 47,935 & 15,588 & 23,716 & 296 & 819 & 262 & 757 & 1,670 & 3,887 & 568 & 74 & NA & 298 & NA \\
\hline
\end{tabular}

$\mathrm{NA}=$ no peak detected 
Table T5. Biostratigraphic datums, Site U1387.

\begin{tabular}{|c|c|c|c|c|c|c|c|c|c|c|c|}
\hline \multirow[b]{2}{*}{ Event } & \multirow[b]{2}{*}{ Reference } & \multirow[b]{2}{*}{ Age (Ma) } & \multicolumn{3}{|c|}{ Hole U1387A depth (mbsf) } & \multicolumn{3}{|c|}{ Hole U1387B depth (mbsf) } & \multicolumn{3}{|c|}{ Hole U1387C depth (mbsf) } \\
\hline & & & Top & Bottom & Mean & Top & Bottom & Mean & Top & Bottom & Mean \\
\hline LrO Emiliania huxleyi (>4 $\mu \mathrm{m})$ & Flores et al., 2010 & 0.01 & 2.55 & 3.75 & 3.15 & & & & & & \\
\hline FO Emiliania huxleyi & Raffi et al., 2006 & 0.26 & 68.85 & 70.35 & 69.60 & 56.10 & 64.18 & 60.14 & & & \\
\hline LO Pseudoemiliania lacunosa & Raffi et al., 2006 & 0.46 & 111.75 & 112.44 & 112.09 & 104.11 & 113.54 & 108.80 & & & \\
\hline Stilostomella extinction & Hayward, 2002; Kawagata et al., 2005 & $0.58-0.7$ & 122.99 & 132.43 & 127.71 & 122.45 & 132.51 & 127.48 & & & \\
\hline LO Reticulofenestra asanoi & Raffi et al., 2006 & 0.90 & 198.15 & 199.20 & 198.68 & 204.40 & 214.09 & 209.24 & & & \\
\hline FO Reticulofenestra asanoi & Raffi et al., 2006 & 1.07 & 257.90 & 259.40 & 258.65 & 242.74 & 243.54 & 243.14 & & & \\
\hline $\begin{array}{l}\text { T paracme Neogloboquadrina } \\
\text { pachyderma (sin) }\end{array}$ & Lourens et al., 2004 & 1.21 & 284.81 & 295.29 & 290.05 & 281.35 & 290.87 & 286.11 & & & \\
\hline LO large Gephyrocapsa (>5.5 $\mu \mathrm{m})$ & Raffi et al., 2006 & 1.24 & 284.81 & 286.34 & 285.58 & 281.30 & 290.87 & 286.08 & & & \\
\hline LO Helicosphaera sellii & Raffi et al., 2006 & 1.25 & 286.34 & 287.83 & 287.09 & 290.87 & 300.76 & 295.81 & & & \\
\hline $\begin{array}{l}\text { B paracme Neogloboquadrina } \\
\text { pachyderma (sin) }\end{array}$ & Lourens et al., 2004 & 1.37 & & & & 319.42 & 337.99 & 328.44 & & & \\
\hline FO large Gephyrocapsa (>5.5 $\mu \mathrm{m})$ & Raffi et al., 2006 & 1.61 & & & & & & & 346.05 & 357.52 & 351.78 \\
\hline LO Calcidiscus macintyrei & Raffi et al., 2006 & 1.66 & & & & & & & 346.05 & 357.52 & 351.78 \\
\hline LO Discoaster brouweri & Raffi et al., 2006 & 1.95 & & & & & & & 452.62 & 458.59 & 455.61 \\
\hline FO Globorotalia inflata & Lourens et al., 2004 & 2.09 & & & & & & & 456.22 & 458.59 & 457.40 \\
\hline LO Globorotalia puncticulata & Lourens et al., 2004 & 2.41 & & & & & & & 456.22 & 458.59 & 457.40 \\
\hline LO Discoaster pentaradiatus & Raffi et al., 2006 & 2.5 & & & & & & & 452.62 & 458.59 & 455.61 \\
\hline LO Discoaster surculus & Raffi et al., 2006 & 2.53 & & & & & & & 452.62 & 458.59 & 455.61 \\
\hline LO Discoaster tamalis & Raffi et al., 2006 & 2.8 & & & & & & & 452.62 & 458.59 & 455.61 \\
\hline LO Sphaeroidinellopsis semulina & Lourens et al., 2004 & 3.19 & & & & & & & 456.22 & 458.59 & 457.40 \\
\hline $\begin{array}{l}\text { Reappearance Globorotalia } \\
\text { puncticulata }\end{array}$ & Lourens et al., 2004 & 3.31 & & & & & & & 489.75 & 492.01 & 490.88 \\
\hline $\begin{array}{l}\text { Disappearance Globorotalia } \\
\text { puncticulata }\end{array}$ & Lourens et al., 2004 & 3.57 & & & & & & & 520.24 & 520.49 & 520.37 \\
\hline LO Sphenolithus spp. & Raffi et al., 2006 & 3.7 & & & & & & & 573.59 & 586.28 & 579.94 \\
\hline LO Globorotalia margaritae & Lourens et al., 2004 & 3.8 & & & & & & & 558.90 & 561.89 & 560.40 \\
\hline $\begin{array}{l}\text { LO Reticulofenestra pseudoumbilicus } \\
(>7 \mu \mathrm{m})\end{array}$ & Raffi et al., 2006 & 3.83 & & & & & & & 586.28 & 597.01 & 591.64 \\
\hline LO Amaurolithus primus & Raffi et al., 2006 & 4.5 & & & & & & & 650.36 & 661.21 & 655.79 \\
\hline FO Globorotalia puncticulata & Lourens et al., 2004 & 4.52 & & & & & & & 629.12 & 632.52 & 630.82 \\
\hline LO Discoaster quinqueramus & Raffi et al., 2006 & 5.54 & & & & & & & 805.68 & 817.18 & 811.43 \\
\hline
\end{tabular}

$\mathrm{LrO}=$ last regular occurrence, $\mathrm{FO}=$ first occurrence, $\mathrm{LO}=$ last occurrence, $\mathrm{T}=\mathrm{top}, \mathrm{B}=$ bottom. $\sin =$ sinistral. 
Table T6. Abundance of nannofossils, Site U1387. This table is available in an oversized format.

Table T7. Abundance of planktonic foraminifers, Holes U1387A and U1387B. This table is available in an oversized format.

Table T8. Abundance of planktonic foraminifers, Hole U1387C. This table is available in an oversized format.

Table T9. Abundance of benthic foraminifers, Site U1387. This table is available in an oversized format.

Table T10. Distribution of ostracods, Site U1387. This table is available in an oversized format. 
Table T11. Abundance of pollen and spores, Site U1387.

\begin{tabular}{|c|c|c|c|c|c|c|c|c|c|c|c|c|c|c|c|c|c|c|c|c|c|c|c|c|c|c|c|c|}
\hline \multirow{2}{*}{$\begin{array}{l}\text { Core, } \\
\text { section }\end{array}$} & \multicolumn{2}{|c|}{ Depth (mbsf) } & \multirow{2}{*}{ 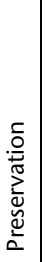 } & \multirow{2}{*}{ 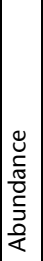 } & \multirow{2}{*}{ 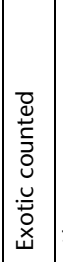 } & \multirow{2}{*}{\multicolumn{2}{|c|}{ 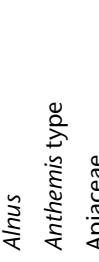 }} & \multirow{2}{*}{\multicolumn{2}{|c|}{ 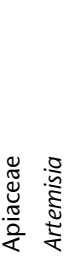 }} & \multirow{2}{*}{$\frac{\stackrel{0}{2}}{\frac{2}{2}}$} & \multirow{2}{*}{$\begin{array}{l}\frac{0}{3} \\
\frac{0}{3} \\
\infty\end{array}$} & \multirow{2}{*}{$=$} & \multirow{2}{*}{ 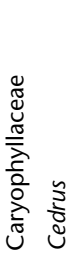 } & \multirow{2}{*}{ 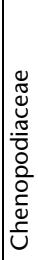 } & \multirow{2}{*}{ 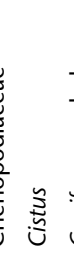 } & & \multirow{2}{*}{ 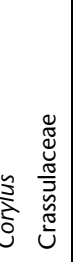 } & \multirow{2}{*}{ 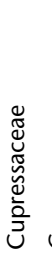 } & \multirow{2}{*}{ 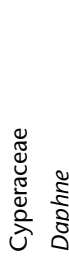 } & \multirow{2}{*}{\multicolumn{2}{|c|}{ 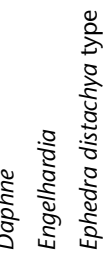 }} & \multirow[t]{2}{*}{ 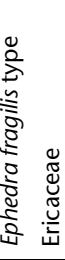 } & \multirow{2}{*}{\multicolumn{2}{|c|}{ 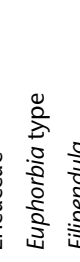 }} & \multirow[t]{2}{*}{ 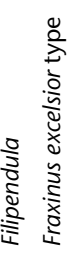 } & \multirow{2}{*}{ 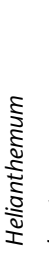 } & \multirow{2}{*}{\multicolumn{2}{|c|}{ 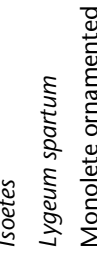 }} \\
\hline & Top & Bottom & & & & & & & & & & & & & & 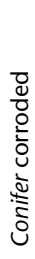 & & & & & & & & & & & & \\
\hline 339-U1387A- & & & & & & & & & & & & & & & & & & & & & & & & & & & & \\
\hline $1 \mathrm{H}-\mathrm{CC}$ & 5.02 & 5.07 & G & A & 53 & $\mathrm{~F}$ & $\mathrm{~F}$ & $\mathrm{~F}$ & C & C & $\mathrm{F}$ & & c & C & $\mathrm{F}$ & $\mathrm{F}$ & $\mathrm{F}$ & $C$ & $\mathrm{~F} \quad \mathrm{~F}$ & $\mathrm{~F}$ & & & A & $\mathrm{F}$ & $\mathrm{F}$ & $\mathrm{F}$ & $\mathrm{F}$ & \\
\hline $10 \mathrm{X}-\mathrm{CC}$ & 80.48 & 80.53 & $G$ & A & 113 & $\mathrm{~F}$ & & & $\mathrm{~F}$ & \begin{tabular}{l|l}
$\mathrm{R}$ & $\mathrm{F}$
\end{tabular} & $\mathrm{R} \quad \mathrm{R}$ & & & C & & $\mathrm{F}$ & $\mathrm{R}$ & $\mathrm{F}$ & $\mathrm{F}$ & & $\mathrm{R}$ & $\mathrm{F}$ & C & $\mathrm{R}$ & $\mathrm{R}$ & & C & \\
\hline $20 \mathrm{X}-\mathrm{CC}$ & 180.39 & 180.44 & $M$ & $A$ & 97 & & $\mathrm{~F}$ & & C & $\mathrm{F}$ & $\mathrm{F}$ & $\mathrm{F}$ & $\mathrm{F}$ & C & & $\mathrm{F}$ & & $\mathrm{F}$ & & & $\mathrm{F}$ & & $\mathrm{F}$ & & & $\mathrm{F}$ & $\mathrm{F}$ & \\
\hline $29 \mathrm{X}-\mathrm{CC}$ & 266.81 & 266.86 & $M$ & A & 153 & & $\mathrm{~F}$ & & $\mathrm{~F}$ & $\mathrm{~F}$ & $\mathrm{~F}$ & & & $\mathrm{~F}$ & & C & & & & & $\mathrm{R}$ & $\mathrm{R}$ & $\mathrm{F}$ & & & & $\mathrm{R}$ & \\
\hline $37 X-C C$ & 342.83 & 342.88 & $M$ & A & 39 & $\mathrm{~F}$ & & & C & $\mathrm{F}$ & & & & C & & A & & & & & & & C & & & & A & \\
\hline 339-U1387C- & & & & & & & & & & & & & & & & & & & & & & & & & & & & \\
\hline 7R-CC & 346.00 & 346.05 & $P$ & A & 90 & & C & & & C & $\mathrm{F}$ & & & C & & C & & & $\mathrm{F}$ & & & $\mathrm{F}$ & $\mathrm{F}$ & & & & $C$ & \\
\hline $10 \mathrm{R}-\mathrm{CC}$ & 376.49 & 376.5 & $\mathrm{P}$ & A & 115 & & & & $\mathrm{R}$ & $\mathrm{F}$ & ᄃ & & $\mathrm{R}$ & $R$ & & C & & & & & & & $\mathrm{R}$ & & & & & \\
\hline $19 \mathrm{R}-\mathrm{CC}$ & 458.54 & 458.59 & $P$ & A & 104 & & $\mathrm{~F}$ & & & $\mathrm{~F}$ & $\mathrm{~F}$ & & & C & & C & & & & & & & $\mathrm{F}$ & & & & & \\
\hline $21 \mathrm{R}-\mathrm{CC}$ & 479.37 & 479.42 & $P$ & A & 105 & $R$ & $\mathrm{~F}$ & & & C & & & & $\mathrm{F}$ & & C & & & & & & $\mathrm{R}$ & & & & & & $\mathrm{r}$ \\
\hline 24R-CC & 510.10 & 510.15 & $\mathrm{P}$ & A & 106 & & $\mathrm{R}$ & $\mathrm{R}$ & & $\mathrm{F}$ & & & $\mathrm{R}$ & $\mathrm{F}$ & & C & & & & & & $\mathrm{R}$ & & & & & $\mathrm{F}$ & \\
\hline $35 \mathrm{R}-\mathrm{CC}$ & 616.22 & 616.30 & $P$ & A & 75 & $\mathrm{~F}$ & $\mathrm{~F}$ & & & C & & & & C & & $\mathrm{F}$ & & & & & & & & & & & $\mathrm{F}$ & $\mathrm{F}$ \\
\hline 48R-CC & 37.45 & 737.50 & $\mathrm{P}$ & A & 112 & & $\mathrm{R}$ & & & $\mathrm{F}$ & & & & $\mathrm{F}$ & & A & & & & & & & & & & & & \\
\hline $61 \mathrm{R}-\mathrm{CC}$ & 865.80 & 865.85 & $P$ & A & 132 & & & & & $\mathrm{~F}$ & & & & $\mathrm{R}$ & & A & & & & $\mathrm{R}$ & & $\mathrm{R}$ & & & & & & \\
\hline
\end{tabular}

Preservation: $\mathrm{G}=$ good, $\mathrm{M}=$ moderate, $\mathrm{P}=$ poor. Abundance: $\mathrm{D}=$ dominant, $\mathrm{A}=$ abundant, $\mathrm{C}=$ common, $\mathrm{F}=$ few, $\mathrm{P}=$ present, $\mathrm{R}=$ rare. See "Biostratigraphy" in the "Methods" chapter (Expedition 339 Scientists, 2013b) for abundance and preservation definitions.

\begin{tabular}{|c|c|c|c|c|c|c|c|c|c|c|c|c|c|c|c|c|c|c|}
\hline \multirow{2}{*}{$\begin{array}{l}\text { Core, } \\
\text { section }\end{array}$} & \multicolumn{2}{|c|}{ Depth (mbsf) } & \multirow{2}{*}{ 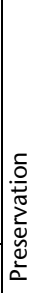 } & \multirow{2}{*}{ 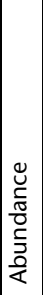 } & \multirow{2}{*}{ 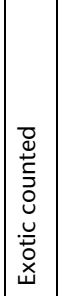 } & \multirow[t]{2}{*}{ 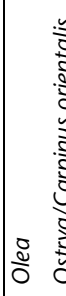 } & \multirow[t]{2}{*}{ 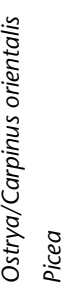 } & \multirow{2}{*}{\multicolumn{2}{|c|}{ 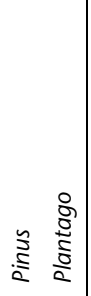 }} & \multirow[t]{2}{*}{. } & \multirow{2}{*}{\multicolumn{2}{|c|}{ 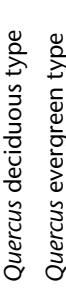 }} & \multirow[t]{2}{*}{ 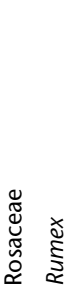 } & \multirow{2}{*}{\multicolumn{2}{|c|}{ 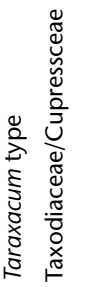 }} & \multirow[t]{2}{*}{ 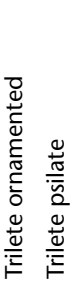 } & \multirow{2}{*}{ 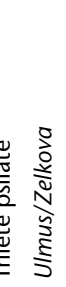 } & \multirow{2}{*}{ 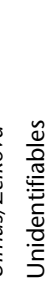 } \\
\hline & Top & Bottom & & & & & & & & & & & & & & & & \\
\hline 339-U1387A- & & & & & & & & & & & & & & & & & & \\
\hline $1 \mathrm{H}-\mathrm{C}$ & 5.02 & 5.07 & G & A & 53 & & & A & & C & C & $\mathrm{F}$ & & C & & & & C \\
\hline $10 \mathrm{X}-\mathrm{CC}$ & 80.48 & 80.53 & G & A & 113 & $\mathrm{~F}$ & & A & $\mathrm{R}$ & $\mathrm{F}$ & $\mathrm{F}$ & & $\mathrm{R}$ & C & & & & C \\
\hline $20 \mathrm{X}-\mathrm{CC}$ & 180.39 & 180.44 & $M$ & A & 97 & & & A & & $\mathrm{F}$ & $\mathrm{F}$ & $\mathrm{F}$ & & C & & & & C \\
\hline $29 X-C C$ & 266.81 & 266.86 & $M$ & A & 153 & & & C & & $\mathrm{F}$ & $\mathrm{R}$ & & $\mathrm{R}$ & C & & & & C \\
\hline $37 X-C C$ & 342.83 & 342.88 & $M$ & A & 39 & C & $\mathrm{F}$ & A & & C & C & C & & A & C & & $\mathrm{F}$ & A \\
\hline 339-U1387C- & & & & & & & & & & & & & & & & & & \\
\hline 7R-CC & 346.00 & 346.05 & $\mathrm{P}$ & A & 90 & $\mathrm{~F}$ & & $\mathrm{~F}$ & C & C & $\mathrm{F}$ & & & A & $\mathrm{F}$ & & $\mathrm{F}$ & A \\
\hline 10R-CC & 376.49 & 376.54 & $P$ & A & 115 & & & & & $\mathrm{~F}$ & & & & A & $\mathrm{R}$ & & & A \\
\hline 19R-CC & 458.54 & 458.59 & $\mathrm{P}$ & A & 104 & & & & & C & $\mathrm{F}$ & $\mathrm{F}$ & & A & & $\mathrm{F}$ & & A \\
\hline $21 \mathrm{R}-\mathrm{CC}$ & 479.37 & 479.42 & $\mathrm{P}$ & A & 105 & $R$ & & $\mathrm{~F}$ & & C & $\mathrm{F}$ & $\mathrm{F}$ & & A & & C & & A \\
\hline 24R-CC & 510.10 & 510.15 & $\mathrm{P}$ & A & 106 & $\mathrm{~F}$ & & $\mathrm{R}$ & & $\mathrm{F}$ & $\mathrm{R}$ & & & A & & $\mathrm{F}$ & $\mathrm{R}$ & A \\
\hline $35 \mathrm{R}-\mathrm{CC}$ & 616.22 & 616.30 & $\mathrm{P}$ & A & 75 & $F$ & $\mathrm{~F}$ & $F \quad F$ & & $\mathrm{~F}$ & $\mathrm{~F}$ & & & A & & C & & A \\
\hline $48 \mathrm{R}-\mathrm{CC}$ & 737.45 & 737.50 & $P$ & A & 112 & & & $\mathrm{R}$ & & $\mathrm{F}$ & & & & C & & $\mathrm{F}$ & & A \\
\hline $61 \mathrm{R}-\mathrm{CC}$ & 865.80 & 865.85 & $\mathrm{P}$ & A & 132 & & & & & $\mathrm{R}$ & & & & C & & $\mathrm{F}$ & & A \\
\hline
\end{tabular}


Table T12. FlexIt tool core orientation data, Site U1387.

\begin{tabular}{lrc}
\hline Core & $\begin{array}{c}\text { Orientation } \\
\text { angle }\left(^{\circ}\right)\end{array}$ & $\begin{array}{c}\text { Orientation } \\
\text { standard } \\
\text { deviation }\left({ }^{\circ}\right)\end{array}$ \\
\hline 339-U1387A- & & \\
4H & 58 & 0.2 \\
$5 \mathrm{H}$ & 5 & 0.0 \\
$6 \mathrm{H}$ & 1 & 0.0 \\
339-U1387B- & & \\
$4 \mathrm{H}$ & 350 & 0.5 \\
$5 \mathrm{H}$ & 146 & 0.9 \\
\hline
\end{tabular}

Table T13. Disturbed intervals, Site U1387. (Continued on next three pages.)

\begin{tabular}{|c|c|c|}
\hline \multirow{2}{*}{$\begin{array}{l}\text { Core, section, } \\
\text { interval }(\mathrm{cm})\end{array}$} & \multicolumn{2}{|r|}{ Drilling disturbance } \\
\hline & Intensity & Comment \\
\hline \multicolumn{3}{|l|}{ 339-U1387A- } \\
\hline $1 \mathrm{H}-1$ & Moderate & Slightly soupy mudline extending downhole to $\sim 2 \mathrm{~cm}$, but do not cull data in this interval. \\
\hline $1 \mathrm{H}-3,96-103$ & High & Whole-round IW sample \\
\hline $2 \mathrm{H}-1,0-1$ & High & Disturbed core top \\
\hline $2 \mathrm{H}-5,145-150$ & High & Whole-round IW sample \\
\hline $3 \mathrm{H}-1,0-10$ & Moderate & Disturbed core top \\
\hline $3 \mathrm{H}-6,136-141$ & High & Whole-round IW sample \\
\hline $4 \mathrm{H}-1,0-15$ & Moderate & Disturbed core top \\
\hline $4 \mathrm{H}-5,144-150$ & High & Whole-round IW sample \\
\hline $4 \mathrm{H}-6,116-121$ & High & $\mathrm{MBIO}$ \\
\hline $5 \mathrm{H}-1,0-13$ & Moderate & Disturbed core top \\
\hline $5 \mathrm{H}-5,145-150$ & High & Whole-round IW sample \\
\hline $6 \mathrm{H}-1$ & Negligible & Undisturbed core top \\
\hline $6 \mathrm{H}-1,145-150$ & High & Whole-round IW sample \\
\hline $7 X-1,0-35$ & Moderate & Disturbed core top \\
\hline $7 X-2,144-150$ & High & Whole-round IW sample \\
\hline $8 X-3,145-150$ & High & Whole-round IW sample \\
\hline $8 X-4,145-150$ & High & $\mathrm{MBIO}$ \\
\hline $9 X-1,0-8$ & High & Disturbed core top \\
\hline $9 X-5,140-150$ & High & Whole-round IW sample \\
\hline $10 X-2,140-150$ & High & Whole-round IW sample \\
\hline $10 X-3,145-150$ & High & $\mathrm{MBIO}$ \\
\hline $11 X-1,0-53$ & High & Disturbed core top \\
\hline $11 X-5,140-150$ & High & Whole-round IW sample \\
\hline $12 X-1,0-25$ & Moderate & Disturbed core top \\
\hline $12 X-5,140-150$ & High & Whole-round IW sample \\
\hline $12 X-6,126-131$ & High & $\mathrm{MBIO}$ \\
\hline $13 X-1,0-4$ & High & Disturbed core top \\
\hline $13 X-5,140-150$ & High & Whole-round IW sample \\
\hline $14 X-1,0-13$ & High & Disturbed core top \\
\hline $14 X-5,140-150$ & High & Whole-round IW sample \\
\hline $14 X-6,116-121$ & High & $\mathrm{MBIO}$ \\
\hline $14 X-7,74-79$ & Void & Void \\
\hline $15 X-5,140-150$ & High & Whole-round IW sample \\
\hline $16 X-5,140-150$ & High & Whole-round IW sample \\
\hline $17 X-1,0-9$ & Moderate & Disturbed core top \\
\hline $17 X-5,140-150$ & High & Whole-round IW sample \\
\hline $18 X-1,0-5$ & High & Disturbed core top \\
\hline $18 X-3,140-150$ & High & Whole-round IW sample \\
\hline $18 X-4,145-150$ & High & $\mathrm{MBIO}$ \\
\hline $19 X-5,140-150$ & High & Whole-round IW sample \\
\hline $20 X-1,0-7$ & High & Disturbed core top \\
\hline $20 X-4,140-150$ & High & Whole-round IW sample \\
\hline $21 X-1,0-14$ & High & Disturbed core top \\
\hline $21 X-5,140-150$ & High & Whole-round IW sample \\
\hline $22 X-1,0-3$ & High & Disturbed core top \\
\hline $22 X-1,3-30$ & Moderate & Whole section is labeled "Caution Disturbed"; probably dropped on the drill floor \\
\hline $22 X-5,140-150$ & High & Whole-round IW sample \\
\hline $22 X-6,145-150$ & High & $\mathrm{MBIO}$ \\
\hline $23 X-1,0-3$ & High & Disturbed core top \\
\hline $23 X-4,139-150$ & High & Whole-round IW sample \\
\hline
\end{tabular}


Table T13 (continued). (Continued on next page.)

\begin{tabular}{|c|c|c|}
\hline \multirow{2}{*}{$\begin{array}{l}\text { Core, section, } \\
\text { interval }(\mathrm{cm})\end{array}$} & \multicolumn{2}{|r|}{ Drilling disturbance } \\
\hline & Intensity & Comment \\
\hline $23 X-7,54-60$ & Void & Void \\
\hline $25 X-1,0-3$ & High & Disturbed core top \\
\hline $26 X-4,140-150$ & High & Whole-round IW sample \\
\hline $26 X-5,143-150$ & High & $\mathrm{MBIO}$ \\
\hline $27 X-1,0-10$ & High & Disturbed core top \\
\hline $29 X-5,140-150$ & High & Whole-round IW sample \\
\hline $31 X-1,0-3$ & High & Disturbed core top \\
\hline $32 X-4,139-150$ & High & Whole-round IW sample \\
\hline $32 X-7,57-61$ & Void & Void \\
\hline $33 X-7,26-29$ & Void & Void \\
\hline $34 X-1,0-3$ & High & Disturbed core top \\
\hline $34 X-4,53-55$ & Void & Void \\
\hline $34 X-6,52-59$ & Void & Void \\
\hline $34 X-6,141-145$ & High & IW tube sample \\
\hline $34 X-6,145-150$ & High & $\mathrm{MBIO}$ \\
\hline $35 X-5,115-129$ & Void & Void \\
\hline $35 X-6,114-124$ & High & Whole-round IW sample \\
\hline $36 X-1,0-8$ & High & Disturbed core top \\
\hline $36 X-6,65-71$ & Void & Void \\
\hline $38 X-5,140-150$ & High & Whole-round IW sample \\
\hline $38 X-6,140-145$ & High & $\mathrm{MBIO}$ \\
\hline \multicolumn{3}{|l|}{ 339-U1387B- } \\
\hline $1 \mathrm{H}-1$ & Moderate & Slightly soupy mudline extending downhole to $\sim 11 \mathrm{~cm}$, but do not cull data in this interval. \\
\hline $3 \mathrm{H}-1,0-5$ & Moderate & Disturbed core top \\
\hline $5 \mathrm{H}-1,0-5$ & Moderate & Disturbed core top \\
\hline $6 \mathrm{X}-1,0-3$ & Moderate & Disturbed core top \\
\hline $7 X-1,0-21$ & High & Disturbed core top \\
\hline $7 X-6,0-61$ & Moderate & Disturbed \\
\hline $9 X-1,0-68$ & High & Disturbed core top \\
\hline $10 X-1,0-2$ & High & Disturbed core top \\
\hline $11 X-1,0-5$ & Moderate & Disturbed core top \\
\hline $12 X-1,0-5$ & Moderate & Disturbed core top \\
\hline $12 X-6,79-85$ & Void & Void \\
\hline $12 X-6,116-120$ & Void & Void \\
\hline $15 X-1,0-10$ & Moderate & Disturbed core top \\
\hline $15 X-7,59-63$ & Void & Void \\
\hline $16 X-1,0-16$ & High & Disturbed core top \\
\hline $16 X-6,17-26$ & Void & Void \\
\hline $17 X-1,0-3$ & High & Disturbed core top \\
\hline $18 X-1,0-2$ & High & Disturbed core top \\
\hline $19 X-1,0-4$ & High & Disturbed core top \\
\hline $21 X-1,0-3$ & High & Disturbed core top \\
\hline $24 X-1,0-3$ & High & Disturbed core top \\
\hline $25 X-1,0-5$ & Moderate & Disturbed core top \\
\hline $27 X-1,0-80$ & High & Disturbed core top \\
\hline $28 X-1$ & Possibly high & $\begin{array}{l}\text { Entire section displays typical biscuit disturbance but is labeled "Caution Disturbed"; possibly } \\
\text { ejected onto the drill floor }\end{array}$ \\
\hline $29 X-1$ & Possibly high & $\begin{array}{l}\text { Entire section displays typical biscuit disturbance but is labeled "Caution Disturbed"; possibly } \\
\text { ejected onto the drill floor }\end{array}$ \\
\hline $31 X-3,47-50$ & Void & Void \\
\hline $32 X-7,74-82$ & Void & Void \\
\hline $35 X-1,0-150$ & High & Virtually entire section is void \\
\hline \multicolumn{3}{|l|}{ 339-U1387C- } \\
\hline $1 W-3,29-36$ & Void & Void \\
\hline $2 \mathrm{R}-2,83-114$ & High & Disturbed \\
\hline $3 R-3,75-90$ & High & Disturbed \\
\hline $5 R-1,0-30$ & High & Disturbed core top \\
\hline $5 R-5,10-59$ & High & Disturbed \\
\hline $6 \mathrm{R}-1,0-35$ & High & Disturbed core top \\
\hline $6 \mathrm{R}-2,0-14$ & High & Disturbed \\
\hline $6 \mathrm{R}-6,0-15$ & High & Disturbed \\
\hline $7 R-1,55-70$ & High & Disturbed \\
\hline 7R-1, 84-94 & High & Disturbed \\
\hline 7R-1, 135-150 & High & Disturbed \\
\hline $7 R-4,90-130$ & High & Disturbed \\
\hline $8 \mathrm{R}-1,120-140$ & High & Disturbed \\
\hline $8 R-2,100-140$ & High & Disturbed \\
\hline $8 R-5,100-115$ & High & Disturbed \\
\hline
\end{tabular}


Table T13 (continued). (Continued on next page.)

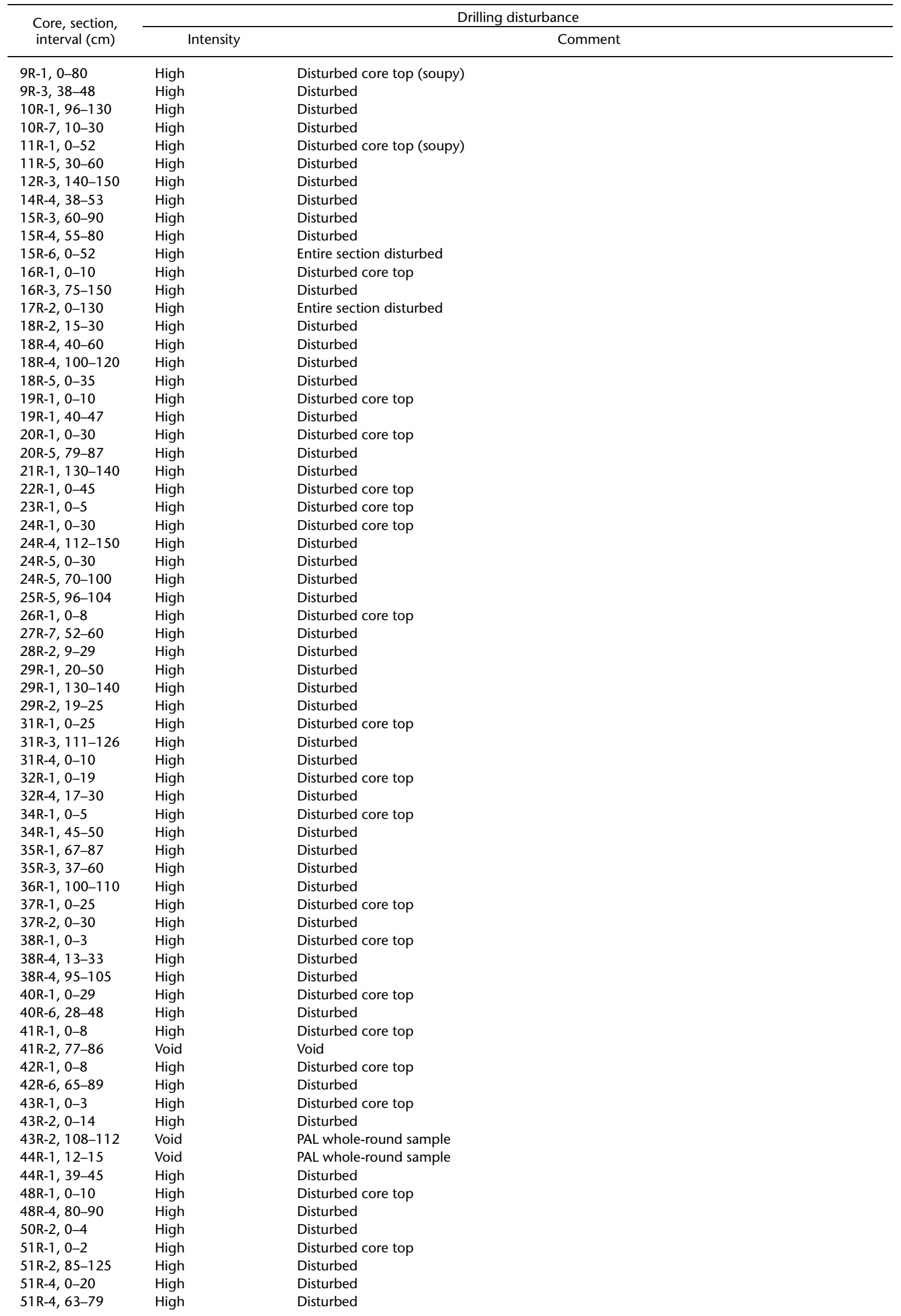


Table T13 (continued).

\begin{tabular}{|c|c|c|}
\hline \multirow{2}{*}{$\begin{array}{l}\text { Core, section, } \\
\text { interval }(\mathrm{cm})\end{array}$} & \multicolumn{2}{|r|}{ Drilling disturbance } \\
\hline & Intensity & Comment \\
\hline $52 \mathrm{R}-1,0-11$ & High & Disturbed core top \\
\hline $53 R-1,0-47$ & High & Disturbed core top \\
\hline $53 R-6,64-69$ & High & $\mathrm{MBIO}$ \\
\hline $54 \mathrm{R}-3,103-110$ & High & PAL whole-round sample \\
\hline $55 \mathrm{R}-2,0-19$ & High & Disturbed \\
\hline $55 R-4,60-70$ & High & Disturbed \\
\hline $55 R-5,32-35$ & High & Disturbed \\
\hline $56 \mathrm{R}-1,0-16$ & High & Disturbed \\
\hline $56 \mathrm{R}-7,52-57$ & Void & PAL whole-round sample \\
\hline $57 R-1$ & Moderate to high & $\begin{array}{l}150 \mathrm{~cm} \text { section is labeled "Caution Disturbed." Given the rare recovery, the section is not culled } \\
\text { but may be anomalous. }\end{array}$ \\
\hline $57 \mathrm{R}-2$ & Moderate to high & $\begin{array}{l}150 \mathrm{~cm} \text { section is labeled "Caution Disturbed." Given the rare recovery, the section is not culled } \\
\text { but may be anomalous. }\end{array}$ \\
\hline $57 R-2,30-55$ & Void & Void \\
\hline $57 R-3$ & Moderate to high & $\begin{array}{l}150 \mathrm{~cm} \text { section is labeled "Caution Disturbed." Given the rare recovery, the section is not culled } \\
\text { but may be anomalous. }\end{array}$ \\
\hline $57 R-3,0-5$ & Void & Void \\
\hline $57 R-4$ & Moderate to high & $\begin{array}{l}150 \mathrm{~cm} \text { section is labeled "Caution Disturbed." Given the rare recovery, the section is not culled } \\
\text { but may be anomalous. }\end{array}$ \\
\hline $57 R-5$ & Moderate to high & $\begin{array}{l}24 \mathrm{~cm} \text { section is labeled "Caution Disturbed." Given the rare recovery, the section is not culled } \\
\text { but may be anomalous. }\end{array}$ \\
\hline $57 R-6$ & Moderate to high & $\begin{array}{l}73 \mathrm{~cm} \text { section is labeled "Caution Disturbed." Given the rare recovery, the section is not culled } \\
\text { but may be anomalous. }\end{array}$ \\
\hline $57 R-6,0-75$ & Moderate to high & $\begin{array}{l}150 \mathrm{~cm} \text { section is labeled "Caution Disturbed." Given the rare recovery, the section is not culled } \\
\text { but may be anomalous. }\end{array}$ \\
\hline $58 \mathrm{R}-1,11-17$ & High & Disturbed \\
\hline $59 \mathrm{R}-1,0-5$ & High & Disturbed \\
\hline $61 \mathrm{R}-1,0-55$ & High & Disturbed \\
\hline $61 \mathrm{R}-3,30-37$ & High & Disturbed \\
\hline
\end{tabular}

$\mathrm{IW}=$ interstitial water, $\mathrm{MBIO}=$ microbiology sample, $\mathrm{PAL}=$ paleontology. 
Table T14. NRM inclination, declination, and intensity data after $20 \mathrm{mT}$ peak field AF demagnetization, Hole U1387A.

\begin{tabular}{|c|c|c|c|c|c|}
\hline $\begin{array}{l}\text { Core, section, } \\
\text { interval }(\mathrm{cm})\end{array}$ & $\begin{array}{l}\text { Depth } \\
\text { (mbsf) }\end{array}$ & $\begin{array}{c}\text { Inclination } \\
\left({ }^{\circ}\right)\end{array}$ & $\begin{array}{l}\text { Declination } \\
\left({ }^{\circ}\right)\end{array}$ & $\begin{array}{c}\text { Flexlt- } \\
\text { corrected } \\
\text { declination } \\
\left(^{\circ}\right)\end{array}$ & $\begin{array}{l}\text { Intensity } \\
(\mathrm{A} / \mathrm{m})\end{array}$ \\
\hline \multicolumn{6}{|l|}{ 339-U1387A- } \\
\hline $1 \mathrm{H}-1$ & 0.00 & & & & \\
\hline $1 \mathrm{H}-1,5$ & 0.05 & & & & \\
\hline $1 \mathrm{H}-1,10$ & 0.10 & & & & \\
\hline $1 \mathrm{H}-1,15$ & 0.15 & 50.9 & 51.1 & & 0.017776 \\
\hline $1 \mathrm{H}-1,20$ & 0.20 & 59 & 42.1 & & 0.018962 \\
\hline $1 \mathrm{H}-1,25$ & 0.25 & 63.1 & 53.7 & & 0.017082 \\
\hline $1 \mathrm{H}-1,30$ & 0.30 & 58.9 & 55.7 & & 0.01835 \\
\hline $1 \mathrm{H}-1,35$ & 0.35 & 56 & 45.7 & & 0.020396 \\
\hline $1 \mathrm{H}-1,40$ & 0.40 & 55.8 & 47 & & 0.021035 \\
\hline $1 \mathrm{H}-1,45$ & 0.45 & 55.7 & 44.9 & & 0.022109 \\
\hline $1 \mathrm{H}-1,50$ & 0.50 & 53.2 & 49.5 & & 0.022993 \\
\hline $1 \mathrm{H}-1,55$ & 0.55 & 51.9 & 47.5 & & 0.021801 \\
\hline $1 \mathrm{H}-1,60$ & 0.60 & 48.7 & 52.8 & & 0.02165 \\
\hline $1 \mathrm{H}-1,65$ & 0.65 & 54.7 & 121.2 & & 0.016566 \\
\hline $1 \mathrm{H}-1,70$ & 0.70 & 85.5 & 123.1 & & 0.015481 \\
\hline $1 \mathrm{H}-1,75$ & 0.75 & 47.8 & 52.6 & & 0.021426 \\
\hline $1 \mathrm{H}-1,80$ & 0.80 & 52.4 & 63 & & 0.019881 \\
\hline $1 \mathrm{H}-1,85$ & 0.85 & 57.9 & 65.5 & & 0.020847 \\
\hline $1 \mathrm{H}-1,90$ & 0.90 & 57.8 & 65.3 & & 0.023903 \\
\hline $1 \mathrm{H}-1,95$ & 0.95 & 56.3 & 61.9 & & 0.026963 \\
\hline $1 \mathrm{H}-1,100$ & 1.00 & 57.7 & 62.3 & & 0.028532 \\
\hline $1 \mathrm{H}-1,105$ & 1.05 & 57.7 & 60.4 & & 0.029895 \\
\hline $1 \mathrm{H}-1,110$ & 1.10 & 57.4 & 58.4 & & 0.03046 \\
\hline $1 \mathrm{H}-1,115$ & 1.15 & 58.3 & 60.6 & & 0.027021 \\
\hline $1 \mathrm{H}-1,120$ & 1.20 & 54.9 & 60.9 & & 0.023706 \\
\hline $1 \mathrm{H}-1,125$ & 1.25 & 45.4 & 55.2 & & 0.024106 \\
\hline $1 \mathrm{H}-1,130$ & 1.30 & 41.6 & 53.5 & & 0.023753 \\
\hline $1 \mathrm{H}-1,135$ & 1.35 & 41.1 & 52.2 & & 0.023396 \\
\hline $1 \mathrm{H}-1,140$ & 1.40 & & & & \\
\hline $1 \mathrm{H}-1,145$ & 1.45 & & & & \\
\hline $1 \mathrm{H}-1,150$ & 1.50 & & & & \\
\hline $1 \mathrm{H}-2$ & 1.50 & & & & \\
\hline $1 \mathrm{H}-2,5$ & 1.55 & & & & \\
\hline $1 \mathrm{H}-2,10$ & 1.60 & & & & \\
\hline $1 \mathrm{H}-2,15$ & 1.65 & 43.3 & 49.5 & & 0.025401 \\
\hline $1 \mathrm{H}-2,20$ & 1.70 & 45.1 & 50 & & 0.024732 \\
\hline $1 \mathrm{H}-2,25$ & 1.75 & 47.2 & 49.9 & & 0.024145 \\
\hline $1 \mathrm{H}-2,30$ & 1.80 & 48.8 & 48.3 & & 0.023688 \\
\hline $1 \mathrm{H}-2,35$ & 1.85 & 49.8 & 48.2 & & 0.022584 \\
\hline $1 \mathrm{H}-2,40$ & 1.90 & 50.9 & 47.8 & & 0.021353 \\
\hline $1 \mathrm{H}-2,45$ & 1.95 & 51.3 & 45.6 & & 0.019905 \\
\hline $1 \mathrm{H}-2,50$ & 2.00 & 53.2 & 47.2 & & 0.017969 \\
\hline $1 \mathrm{H}-2,55$ & 2.05 & 53 & 49.3 & & 0.015944 \\
\hline $1 \mathrm{H}-2,60$ & 2.10 & 54.4 & 54.1 & & 0.013538 \\
\hline $1 \mathrm{H}-2,65$ & 2.15 & 55.5 & 65 & & 0.01071 \\
\hline $1 \mathrm{H}-2,70$ & 2.20 & 61 & 67.4 & & 0.008813 \\
\hline $1 \mathrm{H}-2,75$ & 2.25 & 60.1 & 75.7 & & 0.008298 \\
\hline $1 \mathrm{H}-2,80$ & 2.30 & 58.2 & 75.1 & & 0.009396 \\
\hline $1 \mathrm{H}-2,85$ & 2.35 & 63.6 & 66.8 & & 0.011733 \\
\hline $1 \mathrm{H}-2,90$ & 2.40 & 58.1 & 66.2 & & 0.014659 \\
\hline $1 \mathrm{H}-2,95$ & 2.45 & 52.7 & 66 & & 0.01599 \\
\hline $1 \mathrm{H}-2,100$ & 2.50 & 52.2 & 67.1 & & 0.015072 \\
\hline $1 \mathrm{H}-2,105$ & 2.55 & 50 & 67.3 & & 0.01442 \\
\hline $1 \mathrm{H}-2,110$ & 2.60 & 49.7 & 67 & & 0.014062 \\
\hline $1 \mathrm{H}-2,115$ & 2.65 & 54.6 & 65.1 & & 0.012141 \\
\hline $1 \mathrm{H}-2,120$ & 2.70 & 52.5 & 67.4 & & 0.012244 \\
\hline $1 \mathrm{H}-2,125$ & 2.75 & 47.5 & 68.4 & & 0.014126 \\
\hline $1 \mathrm{H}-2,130$ & 2.80 & 50 & 68.5 & & 0.012186 \\
\hline $1 \mathrm{H}-2,135$ & 2.85 & 54.8 & 71.5 & & 0.01002 \\
\hline
\end{tabular}

Blank cells indicate depth levels where data were either not available (i.e., Flexlt-corrected declination data for nonoriented cores) or removed because of disturbance, voids, or measurement edge effects. Only a portion of this table appears here. The complete table is available in ASCII. 
Table T15. NRM inclination, declination, and intensity data after $20 \mathrm{mT}$ peak field AF demagnetization, Hole U1387B.

\begin{tabular}{|c|c|c|c|c|c|}
\hline $\begin{array}{l}\text { Core, section, } \\
\text { interval }(\mathrm{cm})\end{array}$ & $\begin{array}{l}\text { Depth } \\
\text { (mbsf) }\end{array}$ & $\begin{array}{c}\text { Inclination } \\
\left({ }^{\circ}\right)\end{array}$ & $\begin{array}{c}\text { Declination } \\
\left({ }^{\circ}\right)\end{array}$ & $\begin{array}{c}\text { Flexlt- } \\
\text { corrected } \\
\text { declination } \\
\left(^{\circ}\right)\end{array}$ & $\begin{array}{c}\text { Intensity } \\
(\mathrm{A} / \mathrm{m})\end{array}$ \\
\hline \multicolumn{6}{|l|}{ 339-U1387B- } \\
\hline $1 \mathrm{H}-1$ & 0.00 & & & & \\
\hline $1 \mathrm{H}-1,5$ & 0.05 & & & & \\
\hline $1 \mathrm{H}-1,10$ & 0.10 & & & & \\
\hline $1 \mathrm{H}-1,15$ & 0.15 & 54.6 & 185.5 & & 0.012148 \\
\hline $1 \mathrm{H}-1,20$ & 0.20 & 59.3 & 181.1 & & 0.013186 \\
\hline $1 \mathrm{H}-1,25$ & 0.25 & 61.6 & 186.6 & & 0.012683 \\
\hline $1 \mathrm{H}-1,30$ & 0.30 & 64.8 & 184.3 & & 0.014069 \\
\hline $1 \mathrm{H}-1,35$ & 0.35 & 67.2 & 180.8 & & 0.017428 \\
\hline $1 \mathrm{H}-1,40$ & 0.40 & 65.3 & 181.1 & & 0.018264 \\
\hline $1 \mathrm{H}-1,45$ & 0.45 & 64.7 & 173.6 & & 0.018216 \\
\hline $1 \mathrm{H}-1,50$ & 0.50 & 64.8 & 175.3 & & 0.018354 \\
\hline $1 \mathrm{H}-1,55$ & 0.55 & 64 & 174.5 & & 0.019108 \\
\hline $1 \mathrm{H}-1,60$ & 0.60 & 61.4 & 175 & & 0.021209 \\
\hline $1 \mathrm{H}-1,65$ & 0.65 & 60.1 & 176.6 & & 0.022709 \\
\hline $1 \mathrm{H}-1,70$ & 0.70 & 59 & 178.4 & & 0.023423 \\
\hline $1 \mathrm{H}-1,75$ & 0.75 & 60.8 & 175.9 & & 0.022599 \\
\hline $1 \mathrm{H}-1,80$ & 0.80 & 62.1 & 182.3 & & 0.02208 \\
\hline $1 \mathrm{H}-1,85$ & 0.85 & 60.4 & 183.1 & & 0.023922 \\
\hline $1 \mathrm{H}-1,90$ & 0.90 & 61.3 & 181.5 & & 0.02471 \\
\hline $1 \mathrm{H}-1,95$ & 0.95 & 61.9 & 178.6 & & 0.024852 \\
\hline $1 \mathrm{H}-1,100$ & 1.00 & 62.7 & 177.6 & & 0.025062 \\
\hline $1 \mathrm{H}-1,105$ & 1.05 & 64.1 & 179.1 & & 0.025381 \\
\hline $1 \mathrm{H}-1,110$ & 1.10 & 64.1 & 177.9 & & 0.027181 \\
\hline $1 \mathrm{H}-1,115$ & 1.15 & 63.8 & 175.6 & & 0.028824 \\
\hline $1 \mathrm{H}-1,120$ & 1.20 & 62.5 & 175.1 & & 0.029526 \\
\hline $1 \mathrm{H}-1,125$ & 1.25 & 60.4 & 175 & & 0.02916 \\
\hline $1 \mathrm{H}-1,130$ & 1.30 & 58.8 & 174.4 & & 0.028286 \\
\hline $1 \mathrm{H}-1,135$ & 1.35 & 57.7 & 169.5 & & 0.027327 \\
\hline $1 \mathrm{H}-1,140$ & 1.40 & & & & \\
\hline $1 \mathrm{H}-1,145$ & 1.45 & & & & \\
\hline $1 \mathrm{H}-1,150$ & 1.50 & & & & \\
\hline $1 \mathrm{H}-2$ & 1.50 & & & & \\
\hline $1 \mathrm{H}-2,5$ & 1.55 & & & & \\
\hline $1 \mathrm{H}-2,10$ & 1.60 & & & & \\
\hline $1 \mathrm{H}-2,15$ & 1.65 & 59.7 & 172 & & 0.029271 \\
\hline $1 \mathrm{H}-2,20$ & 1.70 & 61 & 171.4 & & 0.02836 \\
\hline $1 \mathrm{H}-2,25$ & 1.75 & 62.5 & 170.7 & & 0.026324 \\
\hline $1 \mathrm{H}-2,30$ & 1.80 & 62.5 & 172.5 & & 0.025369 \\
\hline $1 \mathrm{H}-2,35$ & 1.85 & 62.5 & 173.9 & & 0.024473 \\
\hline $1 \mathrm{H}-2,40$ & 1.90 & 62.5 & 173.2 & & 0.023505 \\
\hline $1 \mathrm{H}-2,45$ & 1.95 & 64.5 & 170 & & 0.021879 \\
\hline $1 \mathrm{H}-2,50$ & 2.00 & 63.1 & 169.3 & & 0.019939 \\
\hline $1 \mathrm{H}-2,55$ & 2.05 & 62.7 & 172.9 & & 0.016525 \\
\hline $1 \mathrm{H}-2,60$ & 2.10 & 61.7 & 180.1 & & 0.012539 \\
\hline $1 \mathrm{H}-2,65$ & 2.15 & 62.9 & 169 & & 0.008976 \\
\hline $1 \mathrm{H}-2,70$ & 2.20 & 65.3 & 157.9 & & 0.008416 \\
\hline $1 \mathrm{H}-2,75$ & 2.25 & 66.7 & 167.5 & & 0.010576 \\
\hline $1 \mathrm{H}-2,80$ & 2.30 & 62.8 & 168.1 & & 0.015254 \\
\hline $1 \mathrm{H}-2,85$ & 2.35 & 61 & 166 & & 0.017752 \\
\hline $1 \mathrm{H}-2,90$ & 2.40 & 59.3 & 173.9 & & 0.01835 \\
\hline $1 \mathrm{H}-2,95$ & 2.45 & 57.5 & 175.7 & & 0.018698 \\
\hline $1 \mathrm{H}-2,100$ & 2.50 & 57.2 & 173.2 & & 0.018212 \\
\hline $1 \mathrm{H}-2,105$ & 2.55 & 60.3 & 174.5 & & 0.016567 \\
\hline $1 \mathrm{H}-2,110$ & 2.60 & 58.9 & 178.8 & & 0.016481 \\
\hline $1 \mathrm{H}-2,115$ & 2.65 & 57.2 & 181.6 & & 0.016476 \\
\hline $1 \mathrm{H}-2,120$ & 2.70 & 60.9 & 179.2 & & 0.013583 \\
\hline $1 \mathrm{H}-2,125$ & 2.75 & 59.8 & 176.3 & & 0.011519 \\
\hline $1 \mathrm{H}-2,130$ & 2.80 & 58.1 & 180.4 & & 0.010408 \\
\hline
\end{tabular}

Blank cells indicate depth levels where data were either not available (i.e., Flexlt-corrected declination data for nonoriented cores) or removed because of disturbance, voids, or measurement edge effects. Only a portion of this table appears here. The complete table is available in ASCII. 
Table T16. NRM inclination, declination, and intensity data after $20 \mathrm{mT}$ peak field AF demagnetization, Hole U1387C.

\begin{tabular}{|c|c|c|c|c|c|}
\hline $\begin{array}{l}\text { Core, section, } \\
\text { interval }(\mathrm{cm})\end{array}$ & $\begin{array}{l}\text { Depth } \\
\text { (mbsf) }\end{array}$ & $\begin{array}{c}\text { Inclination } \\
\left({ }^{\circ}\right)\end{array}$ & $\begin{array}{l}\text { Declination } \\
\left({ }^{\circ}\right)\end{array}$ & $\begin{array}{c}\text { Flexlt- } \\
\text { corrected } \\
\text { declination } \\
\left(^{\circ}\right)\end{array}$ & $\begin{array}{l}\text { Intensity } \\
(\mathrm{A} / \mathrm{m})\end{array}$ \\
\hline \multicolumn{6}{|l|}{ 339-U1387C- } \\
\hline $2 \mathrm{R}-1,0$ & 290.00 & & & & \\
\hline $2 \mathrm{R}-1,5$ & 290.05 & & & & \\
\hline $2 \mathrm{R}-1,10$ & 290.10 & & & & \\
\hline $2 \mathrm{R}-1,15$ & 290.15 & -59.6 & 276.4 & & 0.0004747 \\
\hline $2 \mathrm{R}-1,20$ & 290.20 & -17.9 & 272.8 & & 0.001326 \\
\hline $2 \mathrm{R}-1,25$ & 290.25 & -25.7 & 326.9 & & 0.001462 \\
\hline $2 \mathrm{R}-1,30$ & 290.30 & -35.9 & 352.2 & & 0.001557 \\
\hline $2 \mathrm{R}-1,35$ & 290.35 & -27.1 & 220.2 & & 0.002201 \\
\hline $2 \mathrm{R}-1,40$ & 290.40 & -43.3 & 241.7 & & 0.002181 \\
\hline $2 \mathrm{R}-1,45$ & 290.45 & -41.2 & 263.6 & & 0.002828 \\
\hline $2 \mathrm{R}-1,50$ & 290.50 & -73 & 295.6 & & 0.00166 \\
\hline $2 \mathrm{R}-1,55$ & 290.55 & -50.6 & 273.8 & & 0.0009214 \\
\hline $2 \mathrm{R}-1,60$ & 290.60 & -28.9 & 253.1 & & 0.001461 \\
\hline $2 \mathrm{R}-1,65$ & 290.65 & -30.3 & 262.5 & & 0.001829 \\
\hline $2 \mathrm{R}-1,70$ & 290.70 & -38.4 & 289.3 & & 0.002036 \\
\hline $2 \mathrm{R}-1,75$ & 290.75 & -33.1 & 312.3 & & 0.001855 \\
\hline $2 \mathrm{R}-1,80$ & 290.80 & -19.7 & 279.8 & & 0.001205 \\
\hline $2 \mathrm{R}-1,85$ & 290.85 & -32 & 225 & & 0.0008337 \\
\hline $2 \mathrm{R}-1,90$ & 290.90 & -41.1 & 252 & & 0.0008708 \\
\hline $2 \mathrm{R}-1,95$ & 290.95 & -24.3 & 263.5 & & 0.0007995 \\
\hline $2 \mathrm{R}-1,100$ & 291.00 & -30.8 & 292.4 & & 0.0009586 \\
\hline $2 \mathrm{R}-1,105$ & 291.05 & -6.8 & 308.4 & & 0.001411 \\
\hline $2 \mathrm{R}-1,110$ & 291.10 & -10.2 & 278.5 & & 0.0008774 \\
\hline $2 \mathrm{R}-1,115$ & 291.15 & -7.4 & 272.4 & & 0.0007937 \\
\hline $2 \mathrm{R}-1,120$ & 291.20 & -20.6 & 266.3 & & 0.0006805 \\
\hline $2 \mathrm{R}-1,125$ & 291.25 & -26.2 & 246.8 & & 0.0007341 \\
\hline $2 \mathrm{R}-1,130$ & 291.30 & -19.8 & 261.6 & & 0.0009323 \\
\hline $2 \mathrm{R}-1,135$ & 291.35 & -25.3 & 292.5 & & 0.0009116 \\
\hline $2 \mathrm{R}-1,140$ & 291.40 & & & & \\
\hline $2 \mathrm{R}-1,145$ & 291.45 & & & & \\
\hline $2 \mathrm{R}-1,150$ & 291.50 & & & & \\
\hline $2 \mathrm{R}-2,0$ & 291.50 & & & & \\
\hline $2 \mathrm{R}-2,5$ & 291.55 & & & & \\
\hline $2 \mathrm{R}-2,10$ & 291.60 & & & & \\
\hline $2 \mathrm{R}-2,15$ & 291.65 & -29.6 & 177.9 & & 0.0003279 \\
\hline $2 \mathrm{R}-2,20$ & 291.70 & 19.4 & 170.2 & & 0.001382 \\
\hline $2 \mathrm{R}-2,25$ & 291.75 & 8.4 & 159.8 & & 0.00103 \\
\hline $2 \mathrm{R}-2,30$ & 291.80 & -71.8 & 33.2 & & 0.0003965 \\
\hline $2 \mathrm{R}-2,35$ & 291.85 & -84 & 68.3 & & 0.0004376 \\
\hline $2 \mathrm{R}-2,40$ & 291.90 & -59.7 & 180.9 & & 0.0005003 \\
\hline $2 \mathrm{R}-2,45$ & 291.95 & -66.3 & 52.8 & & 0.0003893 \\
\hline $2 \mathrm{R}-2,50$ & 292.00 & -80.2 & 291 & & 0.0004611 \\
\hline $2 \mathrm{R}-2,55$ & 292.05 & -74.7 & 185.6 & & 0.0009753 \\
\hline $2 \mathrm{R}-2,60$ & 292.10 & -73.5 & 24.6 & & 0.0008929 \\
\hline $2 \mathrm{R}-2,65$ & 292.15 & -49.5 & 27.9 & & 0.0006283 \\
\hline $2 \mathrm{R}-2,70$ & 292.20 & -50.4 & 115.2 & & 0.0005596 \\
\hline $2 \mathrm{R}-2,75$ & 292.25 & -43.6 & 123.3 & & 0.0007262 \\
\hline $2 \mathrm{R}-2,80$ & 292.30 & & & & \\
\hline $2 \mathrm{R}-2,85$ & 292.35 & & & & \\
\hline $2 \mathrm{R}-2,90$ & 292.40 & & & & \\
\hline $2 R-2,95$ & 292.45 & & & & \\
\hline $2 \mathrm{R}-2,100$ & 292.50 & & & & \\
\hline $2 \mathrm{R}-2,105$ & 292.55 & & & & \\
\hline $2 \mathrm{R}-2,110$ & 292.60 & & & & \\
\hline $2 \mathrm{R}-2,115$ & 292.65 & -29.8 & 148.3 & & 0.0002537 \\
\hline $2 \mathrm{R}-2,120$ & 292.70 & 29.6 & 127.8 & & 0.002499 \\
\hline $2 \mathrm{R}-2,125$ & 292.75 & 61.6 & 173 & & 0.001619 \\
\hline $2 \mathrm{R}-2,130$ & 292.80 & 19.7 & 69.2 & & 0.001119 \\
\hline $2 \mathrm{R}-2,135$ & 292.85 & 12.2 & 105.2 & & 0.0005521 \\
\hline
\end{tabular}

Blank cells indicate depth levels where data were either not available (i.e., Flexlt-corrected declination data for nonoriented cores) or removed because of disturbance, voids, or measurement edge effects. Only a portion of this table appears here. The complete table is available in ASCII. 
Table T17. Headspace sample hydrocarbon concentrations, Holes U1387A and U1387C. (Continued on next page.)

\begin{tabular}{|c|c|c|c|c|c|}
\hline \multirow{2}{*}{$\begin{array}{c}\text { Core, } \\
\text { section }\end{array}$} & \multirow{2}{*}{$\begin{array}{l}\text { Depth } \\
\text { (mbsf) }\end{array}$} & \multicolumn{4}{|c|}{ Concentration (ppmv) } \\
\hline & & Methane & Ethene & Ethane & Propane \\
\hline \multicolumn{6}{|l|}{ 339-U1387A- } \\
\hline $1 \mathrm{H}-4$ & 4.03 & 6.29 & 1.28 & 2.41 & - \\
\hline $2 \mathrm{H}-7$ & 14.00 & 19.68 & - & - & - \\
\hline $3 \mathrm{H}-7$ & 23.41 & $8,325.81$ & - & - & - \\
\hline $4 \mathrm{H}-7$ & 32.70 & $24,284.58$ & - & - & - \\
\hline $5 \mathrm{H}-6$ & 41.00 & $35,145.86$ & - & 0.69 & - \\
\hline $6 \mathrm{H}-3$ & 45.83 & $39,894.36$ & - & 0.84 & - \\
\hline $7 X-3$ & 50.70 & $41,831.39$ & 0.44 & 0.65 & - \\
\hline $8 X-5$ & 61.90 & $41,219.69$ & 0.75 & 1.16 & - \\
\hline $9 X-6$ & 72.60 & $22,657.08$ & 0.6 & 0.87 & - \\
\hline $10 X-3$ & 77.70 & $12,063.99$ & - & 0.64 & - \\
\hline $11 X-6$ & 91.80 & $17,120.88$ & - & 0.72 & - \\
\hline $12 X-6$ & 101.40 & $36,832.83$ & 0.73 & 1.3 & - \\
\hline $13 X-6$ & 111.00 & $7,675.13$ & - & 0.42 & - \\
\hline $14 X-6$ & 120.60 & $7,863.61$ & 0.59 & 0.74 & - \\
\hline $15 X-6$ & 130.10 & $5,417.50$ & - & - & - \\
\hline $16 X-6$ & 139.57 & $9,123.00$ & 0.48 & - & - \\
\hline $17 X-6$ & 149.30 & $6,956.58$ & 0.47 & 0.78 & - \\
\hline $19 X-6$ & 168.40 & $5,800.91$ & - & 0.74 & - \\
\hline $20 X-5$ & 176.39 & $5,652.99$ & - & 0.77 & - \\
\hline $21 X-6$ & 187.60 & $5,956.83$ & - & 0.6 & - \\
\hline $22 X-6$ & 196.02 & $8,038.69$ & - & 1.06 & - \\
\hline $23 X-5$ & 205.20 & $7,047.00$ & 0.72 & 1.3 & - \\
\hline $24 X-6$ & 215.24 & $9,767.75$ & - & 1.22 & - \\
\hline $25 X-5$ & 224.40 & $4,892.02$ & - & 0.84 & - \\
\hline $26 X-5$ & 234.00 & $4,590.35$ & 0.58 & 1.15 & - \\
\hline $27 X-5$ & 243.60 & $6,152.62$ & - & 0.94 & - \\
\hline $28 X-5$ & 253.20 & $6,304.52$ & 0.53 & 1.25 & - \\
\hline $29 X-6$ & 263.25 & $7,781.56$ & 0.73 & 2.02 & - \\
\hline $30 X-4$ & 270.90 & $7,188.73$ & 0.54 & 1.62 & - \\
\hline $31 X-4$ & 280.50 & $7,537.51$ & 0.72 & 1.59 & - \\
\hline $32 X-5$ & 291.60 & $7,494.80$ & - & 1.02 & - \\
\hline $33 X-7$ & 304.20 & $6,209.83$ & - & 1.34 & - \\
\hline $34 X-7$ & 313.54 & $6,858.81$ & - & 1.17 & - \\
\hline $35 X-7$ & 322.74 & $7,587.59$ & 0.45 & 1.6 & - \\
\hline $36 X-8$ & 332.52 & $6,806.71$ & - & 1.44 & - \\
\hline $37 X-7$ & 341.78 & $6,713.03$ & - & 1.3 & - \\
\hline $38 X-7$ & 351.75 & $6,432.03$ & - & 1.17 & - \\
\hline \multicolumn{6}{|c|}{ 339-U1387C- } \\
\hline $8 R-5$ & 353.61 & $5,206.31$ & 0.89 & 3.12 & - \\
\hline $9 R-4$ & 361.70 & $7,389.15$ & 0.53 & 2.93 & - \\
\hline $10 R-5$ & 372.80 & $8,054.09$ & 0.96 & 3.67 & - \\
\hline $11 R-6$ & 383.79 & $4,459.89$ & 0.72 & 2.7 & - \\
\hline $12 R-5$ & 392.00 & $4,586.16$ & - & 2.42 & - \\
\hline $13 R-5$ & 401.60 & $3,087.04$ & 0.44 & 2.4 & - \\
\hline $14 R-4$ & 409.70 & $1,864.57$ & - & 1.87 & - \\
\hline $15 \mathrm{R}-6$ & 422.30 & $6,531.16$ & - & 1.71 & - \\
\hline $16 \mathrm{R}-5$ & 429.90 & $1,217.91$ & - & 0.93 & - \\
\hline $17 R-2$ & 435.40 & $1,053.21$ & - & 0.57 & - \\
\hline $18 \mathrm{R}-7$ & 451.92 & 985.52 & - & 1.08 & - \\
\hline $19 R-4$ & 458.44 & $2,778.71$ & 0.7 & 3.77 & - \\
\hline 20R-7 & 471.60 & $1,051.47$ & 0.49 & 1.6 & - \\
\hline $21 R-5$ & 478.20 & $1,574.03$ & - & 0.9 & - \\
\hline $22 R-4$ & 486.30 & $6,352.14$ & 0.99 & 5.46 & - \\
\hline $23 R-4$ & 495.90 & $6,591.08$ & 0.56 & 3.83 & - \\
\hline $24 R-5$ & 507.00 & $2,932.36$ & 1.26 & 5.81 & - \\
\hline $25 R-4$ & 515.10 & $3,804.61$ & 4.51 & 8.89 & - \\
\hline $26 R-4$ & 524.40 & $5,439.01$ & 0.77 & 7.93 & - \\
\hline $27 R-4$ & 534.00 & $5,838.54$ & 1.3 & 5.37 & - \\
\hline $28 \mathrm{R}-3$ & 542.10 & $5,658.66$ & 0.59 & 3.93 & - \\
\hline $29 R-5$ & 554.70 & $3,213.68$ & 0.64 & 3.81 & - \\
\hline $30 R-5$ & 564.05 & $1,484.70$ & 0.43 & 2.38 & - \\
\hline $31 R-4$ & 572.40 & $1,003.81$ & - & 1.61 & - \\
\hline $32 R-6$ & 585.00 & 73.63 & - & - & - \\
\hline $33 R-7$ & 596.10 & $3,477.37$ & 0.59 & 6.35 & 8.73 \\
\hline $34 R-5$ & 602.70 & $2,820.63$ & - & 2.92 & - \\
\hline $35 \mathrm{R}-7$ & 615.30 & $1,093.04$ & - & 2.52 & - \\
\hline
\end{tabular}


Table T17 (continued).

\begin{tabular}{|c|c|c|c|c|c|}
\hline \multirow{2}{*}{$\begin{array}{l}\text { Core, } \\
\text { section }\end{array}$} & \multirow{2}{*}{$\begin{array}{l}\text { Depth } \\
\text { (mbsf) }\end{array}$} & \multicolumn{4}{|c|}{ Concentration (ppmv) } \\
\hline & & Methane & Ethene & Ethane & Propane \\
\hline $36 \mathrm{R}-3$ & 618.90 & $3,108.09$ & - & 3.8 & - \\
\hline $37 R-5$ & 631.50 & $2,375.27$ & 1.53 & 8.18 & - \\
\hline $38 \mathrm{R}-5$ & 641.10 & $7,402.68$ & 1.35 & 18.85 & - \\
\hline $39 R-3$ & 647.70 & $7,569.26$ & 1.03 & 9.21 & - \\
\hline $40 \mathrm{R}-4$ & 658.80 & $4,730.59$ & 1.36 & 9.38 & - \\
\hline $41 \mathrm{R}-2$ & 665.40 & $8,093.09$ & 0.7 & 10.03 & - \\
\hline $42 \mathrm{R}-4$ & 678.00 & $8,150.32$ & 1.2 & 10.26 & - \\
\hline $43 \mathrm{R}-2$ & 684.68 & $5,817.39$ & 0.42 & 8.06 & - \\
\hline $48 \mathrm{R}-5$ & 736.81 & $3,155.65$ & - & 3.91 & - \\
\hline $49 \mathrm{R}-5$ & 746.80 & $5,142.44$ & - & 13.58 & - \\
\hline 50R-2 & 751.59 & 742.83 & - & 1.68 & - \\
\hline 51R-5 & 764.90 & $1,220.62$ & - & 1.97 & - \\
\hline 52R-2 & 770.99 & $13,634.46$ & 0.53 & 11.35 & - \\
\hline $53 R-4$ & 783.36 & $6,377.92$ & 0.73 & 9.86 & - \\
\hline 54R-2 & 790.26 & $5,309.70$ & 0.64 & 9.05 & - \\
\hline $55 \mathrm{R}-4$ & 802.90 & $6,126.85$ & 0.8 & 12.22 & 6.52 \\
\hline $56 \mathrm{R}-5$ & 814.00 & $17,762.29$ & 1.07 & 19.76 & 18.43 \\
\hline 57R-6 & 823.87 & $1,430.20$ & - & 2.04 & - \\
\hline 58R-5 & 833.20 & $5,518.16$ & - & 4.89 & - \\
\hline $59 \mathrm{R}-6$ & 844.30 & $7,933.80$ & 0.51 & 7.05 & - \\
\hline 61R-7 & 865.05 & $10,042.83$ & - & 6.96 & - \\
\hline
\end{tabular}

$-=$ no data.

Table T18. Results from coulometric and CHNS analysis on whole-round squeezecake samples, Holes U1387A and U1387C. (Continued on next page.)

\begin{tabular}{|c|c|c|c|c|c|c|c|}
\hline $\begin{array}{l}\text { Core, } \\
\text { section }\end{array}$ & $\begin{array}{l}\text { Depth } \\
\text { (mbsf) }\end{array}$ & $\begin{array}{c}\text { Calcium } \\
\text { carbonate } \\
(w t \%)\end{array}$ & $\begin{array}{c}\text { Inorganic } \\
\text { carbon } \\
\text { (wt\%) }\end{array}$ & $\begin{array}{c}\text { Total } \\
\text { carbon } \\
\text { (wt\%) }\end{array}$ & $\begin{array}{c}\text { Nitrogen } \\
(w t \%)\end{array}$ & $\begin{array}{c}\text { Organic } \\
\text { carbon } \\
\text { (wt\%) }\end{array}$ & $\mathrm{C} / \mathrm{N}$ \\
\hline \multicolumn{8}{|l|}{ 339-U1387A- } \\
\hline $1 \mathrm{H}-4$ & 4.72 & 33.874 & 4.061 & 4.82 & 0.06 & 0.76 & 12.67 \\
\hline $2 \mathrm{H}-6$ & 13.84 & 29.535 & 3.541 & 4.39 & 0.07 & 0.85 & 12.14 \\
\hline $3 \mathrm{H}-6$ & 23.27 & 27.553 & 3.304 & 4.32 & 0.09 & 1.02 & 11.33 \\
\hline $4 \mathrm{H}-5$ & 31.36 & 29.438 & 3.53 & 4.11 & 0.05 & 0.58 & 11.60 \\
\hline $5 \mathrm{H}-6$ & 42.24 & 26.096 & 3.129 & 3.76 & 0.08 & 0.63 & 7.88 \\
\hline $6 \mathrm{H}-3$ & 46.76 & 20.911 & 2.507 & 3.47 & 0.11 & 0.96 & 8.73 \\
\hline $7 X-2$ & 50.54 & 29.682 & 3.559 & 4.58 & 0.09 & 1.02 & 11.33 \\
\hline $8 X-5$ & 62.68 & 29.963 & 3.592 & 4.64 & 0.08 & 1.05 & 13.13 \\
\hline $9 X-5$ & 72.41 & 29.608 & 3.550 & 4.30 & 0.06 & 0.75 & 12.50 \\
\hline $11 X-6$ & 92.80 & 35.281 & 4.230 & 5.36 & 0.08 & 1.13 & 14.13 \\
\hline $12 X-6$ & 102.61 & 25.338 & 3.038 & 3.99 & 0.10 & 0.95 & 9.50 \\
\hline $13 X-6$ & 112.02 & 29.114 & 3.491 & 4.33 & 0.05 & 0.84 & 16.80 \\
\hline $14 X-6$ & 121.65 & 26.175 & 3.138 & 4.15 & 0.10 & 1.01 & 10.10 \\
\hline $15 X-6$ & 131.25 & 28.408 & 3.406 & 4.13 & 0.07 & 0.72 & 10.29 \\
\hline $16 X-6$ & 140.92 & 27.309 & 3.274 & 4.28 & 0.10 & 1.01 & 10.10 \\
\hline $17 X-6$ & 150.30 & 26.115 & 3.131 & 4.13 & 0.10 & 1.00 & 10.00 \\
\hline $18 X-6$ & 158.80 & 26.515 & 3.179 & 3.82 & 0.08 & 0.64 & 8.00 \\
\hline $19 X-6$ & 169.43 & 35.593 & 4.268 & 5.15 & 0.08 & 0.88 & 11.00 \\
\hline $20 X-6$ & 179.22 & 25.341 & 3.038 & 3.78 & 0.07 & 0.74 & 10.57 \\
\hline $21 X-6$ & 188.52 & 30.627 & 3.672 & 4.25 & 0.06 & 0.58 & 9.67 \\
\hline $22 X-6$ & 197.37 & 32.006 & 3.837 & 4.71 & 0.09 & 0.87 & 9.67 \\
\hline $23 X-6$ & 207.79 & 29.875 & 3.582 & 4.52 & 0.09 & 0.94 & 10.44 \\
\hline $24 X-6$ & 216.60 & 26.350 & 3.159 & 4.05 & 0.09 & 0.89 & 9.89 \\
\hline $25 X-6$ & 227.01 & 26.099 & 3.129 & 3.94 & 0.07 & 0.81 & 11.57 \\
\hline $26 X-6$ & 236.60 & 23.736 & 2.846 & 3.91 & 0.11 & 1.06 & 9.64 \\
\hline $27 X-6$ & 246.03 & 22.194 & 2.661 & 3.32 & 0.07 & 0.66 & 9.43 \\
\hline $28 X-6$ & 255.68 & 21.657 & 2.597 & 3.14 & 0.06 & 0.54 & 9.00 \\
\hline $29 X-6$ & 264.62 & 27.116 & 3.251 & 4.12 & 0.04 & 0.87 & 21.75 \\
\hline $30 X-6$ & 275.00 & 22.154 & 2.656 & 3.62 & 0.09 & 0.96 & 10.67 \\
\hline $31 X-6$ & 284.03 & 22.883 & 2.744 & 3.60 & 0.08 & 0.86 & 10.75 \\
\hline $32 X-6$ & 294.20 & 20.508 & 2.459 & 2.96 & 0.07 & 0.50 & 7.14 \\
\hline $33 X-6$ & 304.07 & 26.780 & 3.211 & 4.14 & 0.07 & 0.93 & 13.29 \\
\hline $34 X-6$ & 313.41 & 20.377 & 2.443 & 3.21 & 0.07 & 0.77 & 11.00 \\
\hline $35 X-6$ & 322.54 & 28.352 & 3.399 & 4.55 & 0.09 & 1.15 & 12.78 \\
\hline
\end{tabular}


Table T18 (continued).

\begin{tabular}{|c|c|c|c|c|c|c|c|}
\hline $\begin{array}{l}\text { Core, } \\
\text { section }\end{array}$ & $\begin{array}{l}\text { Depth } \\
\text { (mbsf) }\end{array}$ & $\begin{array}{l}\text { Calcium } \\
\text { carbonate } \\
(w t \%)\end{array}$ & $\begin{array}{c}\text { Inorganic } \\
\text { carbon } \\
\text { (wt\%) }\end{array}$ & $\begin{array}{c}\text { Total } \\
\text { carbon } \\
\text { (wt\%) }\end{array}$ & $\begin{array}{c}\text { Nitrogen } \\
\text { (wt\%) }\end{array}$ & $\begin{array}{c}\text { Organic } \\
\text { carbon } \\
(w t \%)\end{array}$ & $\mathrm{C} / \mathrm{N}$ \\
\hline $36 X-6$ & 331.44 & 28.611 & 3.430 & 4.54 & 0.08 & 1.11 & 13.88 \\
\hline $37 X-6$ & 341.68 & 28.860 & 3.460 & 4.45 & 0.06 & 0.99 & 16.50 \\
\hline $38 X-6$ & 351.59 & 18.017 & 2.160 & 2.90 & 0.06 & 0.74 & 12.33 \\
\hline \multicolumn{8}{|l|}{ 339-U1387C- } \\
\hline $8 R-6$ & 356.48 & 24.096 & 2.889 & 3.47 & 0.09 & 0.58 & 6.44 \\
\hline $9 R-5$ & 364.30 & 25.753 & 3.088 & 3.74 & 0.09 & 0.65 & 7.22 \\
\hline $10 R-5$ & 374.19 & 29.389 & 3.524 & 4.18 & 0.07 & 0.66 & 9.43 \\
\hline $11 R-6$ & 385.21 & 26.620 & 3.192 & 3.93 & 0.08 & 0.74 & 9.25 \\
\hline $12 R-5$ & 393.32 & 21.106 & 2.531 & 3.36 & 0.11 & 0.83 & 7.55 \\
\hline $13 R-6$ & 403.99 & 29.060 & 3.484 & 4.45 & 0.1 & 0.97 & 9.70 \\
\hline $14 R-4$ & 410.40 & 18.727 & 2.245 & 2.60 & 0.05 & 0.35 & 7.00 \\
\hline $15 R-5$ & 422.07 & 27.234 & 3.265 & 4.43 & 0.09 & 1.16 & 12.89 \\
\hline $16 R-5$ & 430.49 & 20.571 & 2.466 & 3.67 & 0.12 & 1.20 & 10.00 \\
\hline $18 R-6$ & 451.78 & 22.001 & 2.638 & 3.45 & 0.10 & 0.81 & 8.10 \\
\hline $19 R-4$ & 457.89 & 78.637 & 9.428 & 10.65 & 0.06 & 1.22 & 20.33 \\
\hline $19 R-4$ & 458.40 & 12.883 & 1.545 & 2.84 & 0.11 & 1.30 & 11.82 \\
\hline $20 R-6$ & 471.50 & 22.802 & 2.734 & 4.57 & 0.15 & 1.84 & 12.27 \\
\hline $21 R-5$ & 479.12 & 34.068 & 4.085 & 5.35 & 0.09 & 1.27 & 14.11 \\
\hline $22 \mathrm{R}-6$ & 489.40 & 27.814 & 3.335 & 4.70 & 0.10 & 1.37 & 13.70 \\
\hline $23 R-5$ & 498.37 & 22.200 & 2.662 & 4.59 & 0.13 & 1.93 & 14.85 \\
\hline $24 R-6$ & 509.51 & 18.862 & 2.262 & 4.33 & 0.11 & 2.07 & 18.82 \\
\hline $25 R-5$ & 518.00 & 23.626 & 2.833 & 4.51 & 0.13 & 1.68 & 12.92 \\
\hline $26 \mathrm{R}-6$ & 527.56 & 30.648 & 3.675 & 4.88 & 0.10 & 1.21 & 12.10 \\
\hline $27 R-6$ & 537.69 & 28.451 & 3.411 & & & & \\
\hline $28 \mathrm{R}-4$ & 544.83 & 22.846 & 2.739 & 4.64 & 0.10 & 1.90 & 19.00 \\
\hline $29 R-5$ & 555.77 & 23.573 & 2.826 & 4.62 & 0.13 & 1.79 & 13.77 \\
\hline $30 R-5$ & 564.60 & 29.214 & 3.503 & & & & \\
\hline $30 R-5$ & 564.63 & 30.933 & 3.709 & 5.19 & 0.19 & 1.48 & 7.79 \\
\hline $31 R-4$ & 573.47 & 29.407 & 3.526 & 4.81 & 0.09 & 1.28 & 14.22 \\
\hline $32 R-6$ & 585.91 & 23.333 & 2.798 & 3.99 & 0.09 & 1.19 & 13.22 \\
\hline $33 R-6$ & 595.94 & 19.958 & 2.393 & 4.16 & 0.14 & 1.77 & 12.64 \\
\hline $34 R-5$ & 603.49 & 22.383 & 2.684 & 4.35 & 0.17 & 1.67 & 9.82 \\
\hline $35 \mathrm{R}-1$ & 607.67 & 26.125 & 3.132 & 4.85 & 0.14 & 1.72 & 12.29 \\
\hline $36 \mathrm{R}-3$ & 619.68 & 31.426 & 3.768 & 4.97 & 0.11 & 1.20 & 10.91 \\
\hline $37 R-4$ & 630.54 & 31.086 & 3.727 & 5.58 & 0.04 & 1.85 & 46.25 \\
\hline $38 R-4$ & 640.84 & 31.291 & 3.752 & 6.13 & 0.10 & 2.38 & 23.80 \\
\hline $39 R-4$ & 649.89 & 27.975 & 3.354 & 4.81 & 0.05 & 1.46 & 29.20 \\
\hline $40 R-5$ & 661.17 & 18.232 & 2.186 & 3.63 & 0.09 & 1.44 & 16.00 \\
\hline $41 \mathrm{R}-1$ & 665.20 & 33.504 & 4.017 & 5.64 & 0.08 & 1.62 & 20.25 \\
\hline $42 R-5$ & 680.89 & 36.078 & 4.326 & 5.67 & 0.09 & 1.34 & 14.89 \\
\hline $43 R-2$ & 685.39 & 27.732 & 3.325 & 5.68 & 0.13 & 2.36 & 18.15 \\
\hline $44 \mathrm{R}-1$ & 693.27 & 71.692 & 8.596 & 10.69 & 0.02 & 2.09 & 104.50 \\
\hline $45 \mathrm{R}-1$ & 703.26 & 37.229 & 4.464 & 8.21 & 0.00 & 3.75 & \\
\hline $47 \mathrm{R}-1$ & 721.97 & 38.203 & 4.580 & 6.26 & 0.05 & 1.68 & 33.60 \\
\hline $48 R-5$ & 737.30 & 33.778 & 4.050 & 5.75 & 0.08 & 1.70 & 21.25 \\
\hline $49 R-5$ & 748.01 & 33.521 & 4.019 & 6.05 & 0.08 & 2.03 & 25.36 \\
\hline $50 \mathrm{R}-2$ & 752.30 & 31.740 & 3.805 & 5.48 & 0.09 & 1.67 & 18.56 \\
\hline $51 R-4$ & 764.55 & 29.067 & 3.485 & 5.45 & 0.10 & 1.96 & 19.60 \\
\hline $52 \mathrm{R}-3$ & 772.81 & 24.838 & 2.978 & 4.70 & 0.11 & 1.72 & 15.63 \\
\hline $53 \mathrm{R}-6$ & 786.57 & 31.567 & 3.785 & 5.68 & 0.09 & 1.90 & 21.11 \\
\hline $54 \mathrm{R}-3$ & 792.69 & 29.735 & 3.565 & 5.33 & 0.10 & 1.76 & 17.60 \\
\hline $55 R-4$ & 804.24 & 28.338 & 3.398 & 5.28 & 0.10 & 1.88 & 18.80 \\
\hline $56 \mathrm{R}-5$ & 815.31 & 28.355 & 3.400 & 4.97 & 0.10 & 1.57 & 15.70 \\
\hline $57 R-4$ & 823.38 & 27.568 & 3.305 & 4.94 & 0.10 & 1.63 & 16.30 \\
\hline $58 R-4$ & 833.01 & 29.125 & 3.492 & 5.60 & 0.11 & 2.11 & 19.18 \\
\hline $59 R-6$ & 845.36 & 28.843 & 3.458 & 4.90 & 0.10 & 1.44 & 14.40 \\
\hline $61 R-5$ & 863.33 & 35.907 & 4.305 & 6.60 & 0.10 & 2.29 & 22.90 \\
\hline
\end{tabular}


Table T19. Interstitial water major and trace elements, Hole U1387A.

\begin{tabular}{|c|c|c|c|c|c|c|c|c|c|c|c|c|c|c|}
\hline $\begin{array}{l}\text { Core, section, } \\
\text { interval (cm) }\end{array}$ & $\begin{array}{l}\text { Depth } \\
\text { (mbsf) }\end{array}$ & $\begin{array}{c}\text { Alkalinity } \\
\text { (meq/L) } \\
\text { TITRA_AUTO }\end{array}$ & $\begin{array}{c}\mathrm{NH}_{4}{ }^{+}(\mu \mathrm{M}) \\
\text { SPEC }\end{array}$ & $\begin{array}{c}\mathrm{Ca}^{2+}(\mathrm{mM}) \\
393.4 \mathrm{~nm} \\
\text { ICPAES }\end{array}$ & $\begin{array}{c}\mathrm{Cl}^{-}(\mathrm{mM}) \\
\text { TITRA-AUTO }\end{array}$ & $\begin{array}{c}\mathrm{K}^{+}(\mathrm{mM}) \\
769.9 \mathrm{~nm} \\
\text { ICPAES }\end{array}$ & $\begin{array}{c}\mathrm{Mg}^{2+}(\mathrm{mM}) \\
279.6 \mathrm{~nm} \\
\text { ICPAES }\end{array}$ & $\begin{array}{c}\mathrm{Na}^{+}(\mathrm{mM}) \\
589.6 \mathrm{~nm} \\
\text { ICPAES }\end{array}$ & $\mathrm{Na}^{+} / \mathrm{Cl}^{-}$ & $\begin{array}{c}\mathrm{B}(\mu \mathrm{M}) \\
208.9 \mathrm{~nm} \\
\text { ICPSAES }\end{array}$ & $\begin{array}{c}\mathrm{Ba}(\mu \mathrm{M}) \\
455.4 \mathrm{~nm} \\
\text { ICPAES }\end{array}$ & $\begin{array}{c}\mathrm{Si}(\mu \mathrm{M}) \\
251.6 \mathrm{~nm} \\
\text { ICPAES }\end{array}$ & $\begin{array}{c}\mathrm{SO}_{4}{ }^{2-} \\
(\mathrm{mM}) \\
\mathrm{IC}\end{array}$ & $\begin{array}{c}\mathrm{Sr}(\mu \mathrm{M}) \\
421.6 \mathrm{~nm} \\
\text { ICPAES }\end{array}$ \\
\hline \multicolumn{15}{|l|}{ 339-U1387A- } \\
\hline $1 \mathrm{H}-3,98-103$ & 3.98 & 8.529 & 971 & 7.994 & 581.81 & 10.75 & 52.83 & 498.65 & 0.857 & 357.8 & 6.316 & 195.1 & 19.30 & 75.58 \\
\hline $2 \mathrm{H}-5,145-150$ & 12.45 & 11.274 & 2402 & 4.068 & 578.95 & 9.381 & 41.97 & 504.19 & 0.871 & 386.1 & 10.08 & 207.2 & 0.00 & 64.57 \\
\hline $3 \mathrm{H}-6,136-141$ & 23.36 & 5.747 & 2871 & 4.486 & 573.45 & 8.730 & 36.50 & 499.38 & 0.871 & 401.3 & 14.79 & 156.0 & 0.00 & 74.31 \\
\hline $4 \mathrm{H}-5,145-150$ & 31.45 & 5.608 & 3156 & 4.511 & 576.62 & 9.277 & 32.97 & 491.71 & 0.853 & 300.4 & 31.72 & 97.6 & 0.00 & 77.31 \\
\hline $5 \mathrm{H}-5,145-150$ & 40.95 & 5.261 & 2631 & 5.409 & 572.71 & 7.576 & 34.90 & 491.62 & 0.858 & 395.1 & 30.61 & 190.9 & 0.00 & 83.06 \\
\hline $6 \mathrm{H}-1,145-150$ & 44.45 & 5.419 & 3464 & 5.570 & 572.91 & 7.958 & 33.32 & 485.16 & 0.847 & 391.0 & 26.45 & 271.2 & 0.00 & 83.15 \\
\hline $7 X-2,145-150$ & 50.65 & 5.083 & 3701 & 5.233 & 571.83 & 7.407 & 28.62 & 452.84 & 0.792 & 362.0 & 26.21 & 200.9 & 0.00 & 85.07 \\
\hline $8 X-3,145-150$ & 60.35 & 4.683 & 3586 & 5.678 & 572.86 & 7.354 & 28.98 & 476.80 & 0.832 & 290.3 & 28.47 & 140.8 & 0.00 & 88.78 \\
\hline $9 X-5,140-150$ & 72.50 & 4.151 & 3834 & 6.702 & 573.94 & 7.499 & 31.82 & 490.59 & 0.855 & 261.1 & 29.75 & 118.7 & 0.00 & 92.91 \\
\hline $10 X-2,140-150$ & 77.60 & 4.108 & 3973 & 6.591 & 571.51 & 7.569 & 31.63 & 482.49 & 0.844 & 280.0 & 29.72 & 125.1 & 0.00 & 94.41 \\
\hline $11 X-5,140-150$ & 91.70 & 4.254 & 4027 & 6.318 & 575.26 & 7.507 & 31.08 & 486.93 & 0.847 & 245.9 & 28.83 & 111.2 & 0.00 & 93.20 \\
\hline $12 X-5,140-150$ & 101.30 & 4.692 & 3970 & 5.468 & 569.61 & 6.112 & 26.50 & 429.90 & 0.755 & 278.1 & 28.60 & 224.8 & 0.00 & 94.75 \\
\hline $13 X-5,140-150$ & 110.90 & 4.543 & 4210 & 6.433 & 571.62 & 6.835 & 29.93 & 476.45 & 0.834 & 236.3 & 27.75 & 129.8 & 0.00 & 94.21 \\
\hline $14 X-5,140-150$ & 120.50 & 5.136 & 4284 & 6.510 & 572.00 & 6.857 & 29.93 & 491.86 & 0.860 & 274.8 & 28.05 & 259.7 & 0.00 & 94.74 \\
\hline $15 X-5,140-150$ & 130.00 & 5.512 & 4532 & 6.377 & 571.22 & 6.784 & 28.52 & 466.18 & 0.816 & 230.3 & 30.76 & 171.6 & 0.00 & 94.55 \\
\hline $16 X-5,140-150$ & 139.47 & 5.943 & 4436 & 6.233 & 567.16 & 6.439 & 27.85 & 460.93 & 0.813 & 208.8 & 35.67 & 228.0 & 0.00 & 97.47 \\
\hline $17 X-5,140-150$ & 149.20 & NA & 4773 & 7.041 & 570.24 & 6.538 & 32.84 & 499.33 & 0.876 & 208.1 & 38.33 & 274.5 & 0.00 & 102.36 \\
\hline $18 X-3,140-150$ & 155.70 & 5.713 & 4850 & 6.985 & 571.86 & 6.334 & 30.87 & 484.06 & 0.847 & 207.2 & 37.44 & 268.7 & 0.00 & 100.06 \\
\hline $19 X-5,140-150$ & 168.30 & 5.011 & 4957 & 8.695 & 571.48 & 7.953 & 37.11 & 598.24 & 1.047 & 238.2 & 38.05 & 268.7 & 0.00 & 102.88 \\
\hline $20 X-4,140-150$ & 176.29 & 4.530 & 4842 & 7.501 & 569.76 & 6.359 & 29.73 & 504.60 & 0.886 & 221.8 & 37.52 & 188.0 & 0.00 & 106.10 \\
\hline $21 X-5,140-150$ & 187.50 & 3.346 & 5606 & 6.523 & 569.47 & 6.372 & 27.74 & 473.58 & 0.832 & 150.2 & 40.25 & 93.4 & 0.00 & 107.47 \\
\hline $22 X-5,140-150$ & 195.92 & 3.864 & 5290 & 7.389 & 570.01 & 6.362 & 28.84 & 489.83 & 0.860 & 197.6 & 40.85 & 160.2 & 0.00 & 109.52 \\
\hline $23 X-4,140-150$ & 205.10 & NA & 4730 & 7.620 & 571.26 & 6.199 & 28.78 & 486.21 & 0.851 & 226.3 & 43.58 & 238.1 & 0.00 & 113.33 \\
\hline $26 X-4,140-150$ & 233.90 & 3.685 & 5158 & 9.297 & 574.20 & 6.487 & 29.22 & 499.21 & 0.869 & 179.2 & 44.73 & 279.0 & 0.00 & 115.63 \\
\hline $32 X-4,140-150$ & 263.15 & 4.826 & 4820 & 10.02 & NA & 5.930 & 31.22 & 515.43 & NA & 163.0 & 44.69 & 190.2 & 0.00 & 117.72 \\
\hline $35 X-6,114-124$ & 291.50 & 4.213 & 4715 & 9.709 & 570.66 & 5.536 & 30.51 & 504.76 & 0.885 & 128.7 & 43.57 & 196.6 & 0.00 & 123.52 \\
\hline $35 X-6,114-124$ & 322.64 & 3.701 & 5885 & 9.347 & 569.59 & 5.151 & 28.28 & 495.68 & 0.870 & 134.0 & 43.77 & 270.2 & 0.00 & 124.40 \\
\hline $38 X-5,140-150$ & 350.19 & NA & NA & 8.929 & 566.14 & 5.991 & 27.71 & 488.80 & 0.863 & 44.65 & 49.75 & 128.7 & NA & 125.18 \\
\hline
\end{tabular}

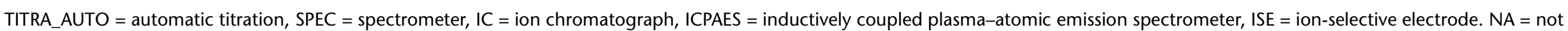
available. 
Table T20. Vertical seismic profile station and traveltime information, Site U1387.

\begin{tabular}{cccccc}
\hline $\begin{array}{c}\text { Depth WSF* } \\
(\mathrm{m})\end{array}$ & $\begin{array}{c}\text { Water depth } \\
(\mathrm{mbsl})\end{array}$ & $\begin{array}{c}\text { One-way } \\
\text { traveltime } \\
(\mathrm{ms})\end{array}$ & $\begin{array}{c}\text { One-way } \\
\text { traveltime, } \\
\text { corrected } \\
(\mathrm{ms})\end{array}$ & $\begin{array}{c}\text { Two-way } \\
\text { traveltime } \\
(\mathrm{ms})\end{array}$ & $\begin{array}{c}\text { Two-way } \\
\text { traveltime } \\
\text { below seabed } \\
(\mathrm{ms})\end{array}$ \\
\hline 135.0 & 693.0 & 442.0 & 451.0 & 902.0 & 164.4 \\
159.0 & 717.0 & 455.5 & 464.5 & 929.0 & 191.4 \\
199.8 & 757.8 & 479.0 & 488.0 & 976.0 & 238.4 \\
246.0 & 804.0 & 504.0 & 513.0 & 1026.0 & 288.4 \\
256.1 & 814.1 & 509.0 & 518.0 & 1036.0 & 298.4 \\
\hline
\end{tabular}

* = seafloor at $558 \mathrm{mbsl}$, two-way traveltime of $737.6 \mathrm{~ms}$ by precision depth recorder. $\dagger=$ between the near field hydrophone and the Versatile Seismic Imager geophone. $\ddagger=$ a correction of $9 \mathrm{~ms}$ is added to the one-way traveltime to adjust to sea level datum.

Table T21. Meters composite depth scale, Site U1387. (Continued on next page.)

\begin{tabular}{|c|c|c|c|c|}
\hline \multirow[b]{2}{*}{ Core } & \multicolumn{2}{|c|}{ Top depth } & \multirow[b]{2}{*}{ Shift (m) } & \multirow[b]{2}{*}{ Offset (m) } \\
\hline & (mbsf) & $(\mathrm{mcd})$ & & \\
\hline \multicolumn{5}{|c|}{ 339-U1387A- } \\
\hline $1 \mathrm{H}$ & 0.00 & 0.00 & 0.00 & 0.00 \\
\hline $2 \mathrm{H}$ & 5.00 & 5.86 & 0.86 & 0.86 \\
\hline $3 \mathrm{H}$ & 14.50 & 16.06 & 1.56 & 0.70 \\
\hline $4 \mathrm{H}$ & 24.00 & 25.88 & 1.88 & 0.32 \\
\hline $5 \mathrm{H}$ & 33.50 & 37.08 & 3.58 & 1.70 \\
\hline $6 \mathrm{H}$ & 43.00 & 46.58 & 3.58 & 0.00 \\
\hline $7 X$ & 47.70 & 55.59 & 7.89 & 4.31 \\
\hline $8 \mathrm{X}$ & 55.90 & 60.49 & 4.59 & -3.30 \\
\hline $9 X$ & 65.10 & 69.72 & 4.62 & 0.03 \\
\hline $10 x$ & 74.70 & 79.42 & 4.72 & 0.10 \\
\hline $11 x$ & 84.30 & 90.02 & 5.72 & 1.00 \\
\hline $12 x$ & 93.90 & 101.16 & 7.26 & 1.54 \\
\hline $13 x$ & 103.50 & 111.23 & 7.73 & 0.47 \\
\hline $14 X$ & 113.10 & 121.83 & 8.73 & 1.00 \\
\hline $15 X$ & 122.60 & 132.33 & 9.73 & 1.00 \\
\hline $16 X$ & 132.20 & 142.93 & 10.73 & 1.00 \\
\hline $17 X$ & 141.80 & 153.53 & 11.73 & 1.00 \\
\hline $18 \mathrm{X}$ & 151.30 & 163.56 & 12.26 & 0.53 \\
\hline $19 x$ & 160.90 & 175.51 & 14.61 & 2.35 \\
\hline $20 x$ & 170.50 & 183.83 & 13.33 & -1.28 \\
\hline $21 x$ & 180.10 & 195.64 & 15.54 & 2.21 \\
\hline $22 x$ & 189.70 & 208.90 & 19.20 & 3.66 \\
\hline $23 x$ & 199.20 & 217.96 & 18.76 & -0.44 \\
\hline $24 X$ & 208.80 & 230.64 & 21.84 & 3.08 \\
\hline $25 X$ & 218.40 & 241.41 & 23.01 & 1.17 \\
\hline $26 x$ & 228.00 & 252.61 & 24.61 & 1.60 \\
\hline $27 X$ & 237.60 & 262.21 & 24.61 & 0.00 \\
\hline $28 \mathrm{X}$ & 247.20 & 271.81 & 24.61 & 0.00 \\
\hline $29 x$ & 256.80 & 283.01 & 26.21 & 1.60 \\
\hline $30 x$ & 266.40 & 293.49 & 27.09 & 0.88 \\
\hline $31 x$ & 276.00 & 304.85 & 28.85 & 1.76 \\
\hline $32 x$ & 285.60 & 315.60 & 30.00 & 1.15 \\
\hline $33 x$ & 295.20 & 325.27 & 30.07 & 0.07 \\
\hline $34 X$ & 304.80 & 336.97 & 32.17 & 2.10 \\
\hline $35 x$ & 314.00 & 346.85 & 32.85 & 0.68 \\
\hline $36 x$ & 323.60 & 357.73 & 34.13 & 1.28 \\
\hline $37 X$ & 333.20 & 367.73 & 34.53 & 0.40 \\
\hline $38 \mathrm{X}$ & 342.80 & 378.53 & 35.73 & 1.20 \\
\hline \multicolumn{5}{|c|}{ 339-U1387B- } \\
\hline $1 \mathrm{H}$ & 0.00 & 0.00 & 0.00 & 0.00 \\
\hline $2 \mathrm{H}$ & 8.90 & 8.48 & -0.42 & -0.42 \\
\hline $3 \mathrm{H}$ & 18.40 & 18.34 & -0.06 & 0.36 \\
\hline $4 \mathrm{H}$ & 27.90 & 27.40 & -0.50 & -0.44 \\
\hline $5 \mathrm{H}$ & 37.40 & 38.59 & 1.19 & 1.69 \\
\hline $6 \mathrm{X}$ & 46.90 & 50.07 & 3.17 & 1.98 \\
\hline $7 X$ & 56.10 & 59.29 & 3.19 & 0.02 \\
\hline $8 \mathrm{x}$ & 65.30 & 68.49 & 3.19 & 0.00 \\
\hline
\end{tabular}

\begin{tabular}{|c|c|c|c|c|}
\hline \multirow[b]{2}{*}{ Core } & \multicolumn{2}{|c|}{ Top depth } & \multirow[b]{2}{*}{ Shift (m) } & \multirow[b]{2}{*}{ Offset (m) } \\
\hline & (mbsf) & (mcd) & & \\
\hline $9 X$ & 74.90 & 79.09 & 4.19 & 1.00 \\
\hline $10 x$ & 84.50 & 90.32 & 5.82 & 1.63 \\
\hline $11 x$ & 94.10 & 100.92 & 6.82 & 1.00 \\
\hline $12 x$ & 103.70 & 111.52 & 7.82 & 1.00 \\
\hline $13 x$ & 113.30 & 122.53 & 9.23 & 1.41 \\
\hline $14 X$ & 122.90 & 132.45 & 9.55 & 0.32 \\
\hline $15 X$ & 132.40 & 143.68 & 11.28 & 1.73 \\
\hline $16 x$ & 142.00 & 154.14 & 12.14 & 0.86 \\
\hline $17 X$ & 147.00 & 160.54 & 13.54 & 1.40 \\
\hline $18 \mathrm{X}$ & 156.60 & 169.84 & 13.24 & -0.30 \\
\hline $19 X$ & 166.20 & 179.06 & 12.86 & -0.38 \\
\hline $20 x$ & 175.80 & 190.06 & 14.26 & 1.40 \\
\hline $21 X$ & 185.40 & 202.61 & 17.21 & 2.95 \\
\hline $22 x$ & 194.90 & 212.75 & 17.85 & 0.64 \\
\hline $23 x$ & 204.40 & 223.35 & 18.95 & 1.10 \\
\hline $24 X$ & 214.00 & 234.13 & 20.13 & 1.18 \\
\hline $25 x$ & 223.60 & 246.85 & 23.25 & 3.12 \\
\hline $26 x$ & 233.10 & 256.50 & 23.40 & 0.15 \\
\hline $27 X$ & 242.70 & 266.54 & 23.84 & 0.44 \\
\hline $28 \mathrm{X}$ & 252.30 & 276.19 & 23.89 & 0.05 \\
\hline $29 x$ & 261.90 & 286.91 & 25.01 & 1.12 \\
\hline $30 x$ & 271.50 & 296.99 & 25.49 & 0.48 \\
\hline $31 x$ & 281.10 & 309.91 & 28.81 & 3.32 \\
\hline $32 x$ & 290.70 & 320.01 & 29.31 & 0.50 \\
\hline $33 x$ & 300.30 & 331.11 & 30.81 & 1.50 \\
\hline $34 X$ & 309.50 & 341.31 & 31.81 & 1.00 \\
\hline $35 x$ & 319.10 & 351.91 & 32.81 & 1.00 \\
\hline $36 x$ & 328.70 & 362.51 & 33.81 & 1.00 \\
\hline \multicolumn{5}{|c|}{ 339-U1387C- } \\
\hline $1 \mathrm{~W}$ & 0.00 & 100.43 & 100.43 & 0.00 \\
\hline $2 \mathrm{R}$ & 290.00 & 325.20 & 35.20 & 0.00 \\
\hline $3 R$ & 299.60 & 335.20 & 35.60 & 0.40 \\
\hline $4 \mathrm{R}$ & 309.20 & 344.80 & 35.60 & 0.00 \\
\hline $5 \mathrm{R}$ & 318.80 & 354.87 & 36.07 & 0.47 \\
\hline $6 \mathrm{R}$ & 328.40 & 363.77 & 35.37 & -0.70 \\
\hline $7 \mathrm{R}$ & 338.00 & 374.67 & 36.67 & 1.30 \\
\hline $8 \mathrm{R}$ & 347.60 & 384.77 & 37.17 & 0.50 \\
\hline $9 \mathrm{R}$ & 357.20 & 395.37 & 38.17 & 1.00 \\
\hline $10 \mathrm{R}$ & 366.80 & 405.97 & 39.17 & 1.00 \\
\hline $11 \mathrm{R}$ & 376.40 & 416.57 & 40.17 & 1.00 \\
\hline $12 \mathrm{R}$ & 386.00 & 427.17 & 41.17 & 1.00 \\
\hline $13 \mathrm{R}$ & 395.60 & 437.77 & 42.17 & 1.00 \\
\hline $14 \mathrm{R}$ & 405.20 & 448.37 & 43.17 & 1.00 \\
\hline $15 R$ & 414.80 & 458.97 & 44.17 & 1.00 \\
\hline $16 \mathrm{R}$ & 424.30 & 469.47 & 45.17 & 1.00 \\
\hline $17 R$ & 433.90 & 480.07 & 46.17 & 1.00 \\
\hline $18 \mathrm{R}$ & 443.40 & 490.57 & 47.17 & 1.00 \\
\hline $19 \mathrm{R}$ & 453.00 & 501.17 & 48.17 & 1.00 \\
\hline
\end{tabular}


Table T21 (continued).

\begin{tabular}{|c|c|c|c|c|}
\hline \multirow[b]{2}{*}{ Core } & \multicolumn{2}{|c|}{ Top depth } & \multirow[b]{2}{*}{ Shift (m) } & \multirow[b]{2}{*}{ Offset (m) } \\
\hline & (mbsf) & (mcd) & & \\
\hline $20 \mathrm{R}$ & 462.60 & 511.77 & 49.17 & 1.00 \\
\hline $21 R$ & 472.20 & 522.37 & 50.17 & 1.00 \\
\hline $22 \mathrm{R}$ & 481.80 & 532.97 & 51.17 & 1.00 \\
\hline $23 R$ & 491.40 & 543.57 & 52.17 & 1.00 \\
\hline $24 \mathrm{R}$ & 501.00 & 554.17 & 53.17 & 1.00 \\
\hline $25 \mathrm{R}$ & 510.60 & 564.77 & 54.17 & 1.00 \\
\hline $26 \mathrm{R}$ & 519.90 & 575.07 & 55.17 & 1.00 \\
\hline $27 \mathrm{R}$ & 529.50 & 585.67 & 56.17 & 1.00 \\
\hline $28 \mathrm{R}$ & 539.10 & 596.27 & 57.17 & 1.00 \\
\hline $29 R$ & 548.70 & 606.87 & 58.17 & 1.00 \\
\hline $30 \mathrm{R}$ & 558.30 & 617.47 & 59.17 & 1.00 \\
\hline $31 \mathrm{R}$ & 567.90 & 628.07 & 60.17 & 1.00 \\
\hline $32 \mathrm{R}$ & 577.50 & 638.67 & 61.17 & 1.00 \\
\hline $33 R$ & 587.10 & 649.27 & 62.17 & 1.00 \\
\hline $34 \mathrm{R}$ & 596.70 & 659.87 & 63.17 & 1.00 \\
\hline $35 \mathrm{R}$ & 606.30 & 670.47 & 64.17 & 1.00 \\
\hline $36 \mathrm{R}$ & 615.90 & 681.07 & 65.17 & 1.00 \\
\hline $37 R$ & 625.50 & 691.67 & 66.17 & 1.00 \\
\hline $38 \mathrm{R}$ & 635.10 & 702.27 & 67.17 & 1.00 \\
\hline $39 R$ & 644.70 & 712.87 & 68.17 & 1.00 \\
\hline $40 \mathrm{R}$ & 654.30 & 723.47 & 69.17 & 1.00 \\
\hline $41 \mathrm{R}$ & 663.90 & 734.07 & 70.17 & 1.00 \\
\hline $42 \mathrm{R}$ & 673.50 & 744.67 & 71.17 & 1.00 \\
\hline $43 R$ & 683.20 & 755.37 & 72.17 & 1.00 \\
\hline $44 \mathrm{R}$ & 692.90 & 766.07 & 73.17 & 1.00 \\
\hline $45 \mathrm{R}$ & 702.50 & 776.67 & 74.17 & 1.00 \\
\hline $46 \mathrm{R}$ & 712.00 & 787.17 & 75.17 & 1.00 \\
\hline $47 R$ & 721.60 & 797.77 & 76.17 & 1.00 \\
\hline $48 \mathrm{R}$ & 731.20 & 808.37 & 77.17 & 1.00 \\
\hline $49 \mathrm{R}$ & 740.80 & 818.97 & 78.17 & 1.00 \\
\hline $50 \mathrm{R}$ & 750.40 & 829.57 & 79.17 & 1.00 \\
\hline $51 \mathrm{R}$ & 760.00 & 840.17 & 80.17 & 1.00 \\
\hline $52 \mathrm{R}$ & 769.60 & 850.77 & 81.17 & 1.00 \\
\hline $53 R$ & 779.20 & 861.37 & 82.17 & 1.00 \\
\hline $54 \mathrm{R}$ & 788.80 & 871.97 & 83.17 & 1.00 \\
\hline $55 \mathrm{R}$ & 798.40 & 882.57 & 84.17 & 1.00 \\
\hline $56 \mathrm{R}$ & 808.00 & 893.17 & 85.17 & 1.00 \\
\hline $57 R$ & 817.60 & 903.77 & 86.17 & 1.00 \\
\hline $58 \mathrm{R}$ & 827.20 & 914.37 & 87.17 & 1.00 \\
\hline $59 R$ & 836.80 & 924.97 & 88.17 & 1.00 \\
\hline $60 \mathrm{R}$ & 846.40 & 935.57 & 89.17 & 1.00 \\
\hline $61 \mathrm{R}$ & 856.00 & 946.17 & 90.17 & 1.00 \\
\hline $62 \mathrm{R}$ & 865.60 & 956.77 & 91.17 & 1.00 \\
\hline
\end{tabular}


Table T22. Splice tie points, Site U1387. (Continued on next page.)

\begin{tabular}{|c|c|c|c|c|c|c|}
\hline \multirow{2}{*}{$\begin{array}{l}\text { Hole, core, section, } \\
\text { interval }(\mathrm{cm})\end{array}$} & \multicolumn{2}{|c|}{ Depth } & & \multirow{2}{*}{$\begin{array}{l}\text { Hole, core, section, } \\
\text { interval }(\mathrm{cm})\end{array}$} & \multicolumn{2}{|c|}{ Depth } \\
\hline & (mbsf) & $(\mathrm{mcd})$ & & & (mbsf) & $(\mathrm{mcd})$ \\
\hline \multirow[t]{2}{*}{$339-$} & & & & $339-$ & & \\
\hline & & & & U1387B-1H-1, 0 & 0.00 & 0.00 \\
\hline U1387B-1H-6, 49 & 7.99 & 7.99 & Tie to & U1387A-2H-2, 63 & 7.13 & 7.99 \\
\hline U1387A-2H-4, 46 & 9.96 & 10.82 & Tie to & U1387B-2H-2, 84 & 11.24 & 10.82 \\
\hline U1387B-2H-7, 57 & 18.28 & 17.86 & Tie to & U1387A-3H-2, 30 & 16.30 & 17.86 \\
\hline U1387A-3H-4, 79 & 19.79 & 21.35 & Tie to & U1387B-3H-2, 151 & 21.41 & 21.35 \\
\hline U1387B-3H-7, 22 & 27.43 & 27.37 & Tie to & U1387A-4H-1, 149 & 25.49 & 27.37 \\
\hline U1387A-4H-3, 46 & 27.45 & 29.33 & Tie to & U1 387B-4H-2, 43 & 29.83 & 29.33 \\
\hline U1387B-4H-7, 56 & 37.46 & 36.96 & Append to & U1387A-5H-1, 15 & 33.65 & 37.23 \\
\hline U1387A-5H-3, 62 & 37.13 & 40.71 & Tie to & U1387B-5H-2, 61 & 39.52 & 40.71 \\
\hline U1387B-5H-7, 32 & 46.44 & 47.63 & Tie to & U1387A-6H-1, 105 & 44.05 & 47.63 \\
\hline U1387A-6H-3, 87 & 46.70 & 50.28 & Tie to & U1387B-6X-1, 21 & 47.11 & 50.28 \\
\hline U1387B-6X-5, 16 & 53.06 & 56.23 & Tie to & U1387A-7X-1, 64 & 48.34 & 56.23 \\
\hline U1387A-7X-3, 100 & 51.70 & 59.59 & Tie to & U1387B-7X-1, 30 & 56.40 & 59.59 \\
\hline U1387B-7X-5, 41 & 62.51 & 65.70 & Tie to & U1387A-8X-4, 71 & 61.11 & 65.70 \\
\hline U1387A-8X-5, 87 & 62.77 & 67.36 & Append to & U1387B-8X-1, 0 & 65.30 & 68.49 \\
\hline U1387B-8X-6, 25 & 73.05 & 76.24 & Tie to & U1387A-9X-5, 52 & 71.62 & 76.24 \\
\hline U1387A-9X-7, 60 & 74.32 & 78.94 & Append to & U1387A-10X-1, 3 & 74.73 & 79.45 \\
\hline U1387A-10X-4, 105 & 80.25 & 84.97 & Append to & U1387B-10X-1, 4 & 84.54 & 90.36 \\
\hline U1387B-10X-7, 68 & 93.89 & 99.71 & Append to & U1387B-11X-1, 8 & 94.18 & 101.00 \\
\hline U1387B-11X-7, 14 & 103.03 & 109.85 & Tie to & U1387A-12X-6, 119 & 102.59 & 109.85 \\
\hline U1387A-12X-7, 66 & 103.37 & 110.63 & Append to & U1387A-13X-1, 5 & 103.55 & 111.28 \\
\hline U1387A-13X-7, 58 & 112.69 & 120.42 & Append to & U1387A-14X-1, 15 & 113.25 & 121.98 \\
\hline U1387A-14X-2, 22 & 114.82 & 123.55 & Tie to & U1387B-13X-1, 102 & 114.32 & 123.55 \\
\hline U1387B-13X-6, 117 & 121.97 & 131.20 & Append to & U1387B-14X-1, 3 & 122.93 & 132.48 \\
\hline U1387B-14X-7, 55 & 132.16 & 141.71 & Append to & U1387A-16X-2, 3 & 133.60 & 144.33 \\
\hline U1387A-16X-2, 42 & 133.99 & 144.72 & Tie to & U1387B-15X-1, 104 & 133.44 & 144.72 \\
\hline U1387B-15X-7, 59 & 141.70 & 152.98 & Append to & U1387B-16X-1, 16 & 142.16 & 154.30 \\
\hline U1387B-16X-3, 135 & 146.35 & 158.49 & Tie to & U1387A-17X-4, 46 & 146.76 & 158.49 \\
\hline U1387A-17X-5, 112 & 148.92 & 160.65 & Tie to & U1387B-17X-1, 11 & 147.11 & 160.65 \\
\hline U1387B-17X-7, 69 & 156.40 & 169.94 & Append to & U1387B-18X-1, 3 & 156.63 & 169.87 \\
\hline U1387B-18X-7, 22 & 164.62 & 177.86 & Tie to & U1387A-19X-2, 85 & 163.25 & 177.86 \\
\hline U1387A-19X-4, 108 & 166.48 & 181.09 & Tie to & U1387B-19X-2, 53 & 168.23 & 181.09 \\
\hline U1387B-19X-6, 10 & 173.80 & 186.66 & Tie to & U1387A-20X-2, 144 & 173.33 & 186.66 \\
\hline U1387A-20X-5, 116 & 177.55 & 190.88 & Tie to & U1387B-20X-1, 82 & 176.62 & 190.88 \\
\hline U1387B-20X-5, 118 & 182.98 & 197.24 & Tie to & U1387A-21X-2, 10 & 181.70 & 197.24 \\
\hline U1387A-21X-5, 109 & 187.18 & 202.72 & Tie to & U1387B-21X-1, 11 & 185.51 & 202.72 \\
\hline U1387B-21X-5, 107 & 192.47 & 209.68 & Tie to & U1387A-22X-2, 46 & 190.48 & 209.68 \\
\hline U1387A-22X-4, 150 & 194.52 & 213.72 & Tie to & U1387B-22X-1, 97 & 195.87 & 213.72 \\
\hline U1387B-22X-6, 43 & 202.83 & 220.68 & Tie to & U1387A-23X-2, 122 & 201.92 & 220.68 \\
\hline U1387A-23X-4, 123 & 204.93 & 223.69 & Tie to & U1387B-23X-1, 34 & 204.74 & 223.69 \\
\hline U1387B-23X-5, 149 & 211.89 & 230.84 & Tie to & U1387A-24X-1, 20 & 209.00 & 230.84 \\
\hline U1387A-24X-5, 77 & 214.50 & 236.34 & Tie to & U1387B-24X-2, 71 & 216.21 & 236.34 \\
\hline U1387B-24X-7, 57 & 223.09 & 243.22 & Tie to & U1387A-25X-2, 31 & 220.21 & 243.22 \\
\hline U1387A-25X-4, 150 & 224.40 & 247.41 & Tie to & U1387B-25X-1, 56 & 224.16 & 247.41 \\
\hline U1387B-25X-6, 11 & 231.21 & 254.46 & Tie to & U1387A-26X-2, 35 & 229.85 & 254.46 \\
\hline U1387A-26X-4, 18 & 232.68 & 257.29 & Tie to & U1387B-26X-1, 79 & 233.89 & 257.29 \\
\hline U1387B-26X-5, 26 & 239.36 & 262.76 & Tie to & U1387A-27X-1, 55 & 238.15 & 262.76 \\
\hline U1387A-27X-6, 90 & 246.00 & 270.61 & Append to & U1387A-28X-1, 10 & 247.30 & 271.91 \\
\hline U1387A-28X-4, 146 & 253.16 & 277.77 & Tie to & U1387B-28X-2, 16 & 253.88 & 277.77 \\
\hline U1387B-28X-6, 121 & 260.93 & 284.82 & Tie to & U1387A-29X-2, 136 & 258.61 & 284.82 \\
\hline U1387A-29X-5, 46 & 262.21 & 288.42 & Tie to & U1387B-29X-1, 151 & 263.41 & 288.42 \\
\hline U1387B-29X-5, 143 & 269.33 & 294.34 & Tie to & U1387A-30X-1, 85 & 267.25 & 294.34 \\
\hline U1387A-30X-4, 84 & 271.74 & 298.83 & Tie to & U1387B-30X-2, 34 & 273.34 & 298.83 \\
\hline U1387B-30X-7, 38 & 280.88 & 306.37 & Tie to & U1387A-31X-1, 152 & 277.52 & 306.37 \\
\hline U1387A-31X-5, 37 & 282.37 & 311.22 & Tie to & U1387B-31X-1, 131 & 282.41 & 311.22 \\
\hline U1387B-31X-5, 117 & 288.27 & 317.08 & Tie to & U1387A-32X-1, 148 & 287.08 & 317.08 \\
\hline U1387A-32X-4, 143 & 291.53 & 321.53 & Tie to & U1387B-32X-2, 100 & 292.22 & 321.53 \\
\hline U1387B-32X-7, 105 & 299.74 & 329.05 & Tie to & U1387C-2R-3, 85 & 293.85 & 329.05 \\
\hline U1387C-2R-7, 28 & 299.19 & 334.39 & Tie to & U1387B-33X-3, 138 & 303.58 & 334.39 \\
\hline U1387B-33X-4, 128 & 304.98 & 335.79 & Tie to & U1387C-3R-1, 59 & 300.19 & 335.79 \\
\hline U1387C-3R-4, 135 & 305.45 & 341.05 & Tie to & U1387A-34X-3, 134 & 308.88 & 341.05 \\
\hline U1387A-34X-4, 100 & 310.04 & 342.21 & Tie to & U1387B-34X-1, 90 & 310.40 & 342.21 \\
\hline U1387B-34X-7, 66 & 318.47 & 350.28 & Tie to & U1387A-35X-3, 43 & 317.43 & 350.28 \\
\hline U1387A-35X-4, 95 & 319.45 & 352.30 & Tie to & U1387B-35X-2, 11 & 319.49 & 352.30 \\
\hline U1387B-35X-5, 127 & 325.15 & 357.96 & Tie to & U1387C-5R-3, 9 & 321.89 & 357.96 \\
\hline U1387C-5R-6, 63 & 326.93 & 363.00 & Tie to & U1387B-36X-1, 49 & 329.19 & 363.00 \\
\hline U1387B-36X-5, 143 & 336.13 & 369.94 & Tie to & U1387A-37X-2, 71 & 335.41 & 369.94 \\
\hline
\end{tabular}


Table T22 (continued).

\begin{tabular}{|c|c|c|c|c|c|c|}
\hline \multirow{2}{*}{$\begin{array}{l}\text { Hole, core, section, } \\
\text { interval }(\mathrm{cm})\end{array}$} & \multicolumn{2}{|c|}{ Depth } & & \multirow{2}{*}{$\begin{array}{l}\text { Hole, core, section, } \\
\text { interval }(\mathrm{cm})\end{array}$} & \multicolumn{2}{|c|}{ Depth } \\
\hline & (mbsf) & (mcd) & & & (mbsf) & (mcd) \\
\hline U1387A-37X-6, 33 & 341.02 & 375.55 & Tie to & U1387C-7R-1, 88 & 338.88 & 375.55 \\
\hline U1387C-7R-6, 36 & 345.58 & 382.25 & Tie to & U1387A-38X-3, 73 & 346.52 & 382.25 \\
\hline U1387A-38X-5, 121 & 349.99 & 385.72 & Tie to & U1387C-8R-1, 95 & 348.55 & 385.72 \\
\hline U1387C-8R-7, 66 & 357.27 & 394.44 & & & & \\
\hline
\end{tabular}


Table T23. Magnetic susceptibility splice, Site U1387.

\begin{tabular}{|c|c|c|c|c|}
\hline \multirow{2}{*}{$\begin{array}{l}\text { Core, section, } \\
\text { interval }(\mathrm{cm})\end{array}$} & \multicolumn{2}{|c|}{ Depth } & \multirow[b]{2}{*}{ Offset (m) } & \multirow{2}{*}{$\begin{array}{c}\text { Magnetic } \\
\text { susceptibility }\end{array}$} \\
\hline & (mbsf) & (mcd) & & \\
\hline \multicolumn{5}{|l|}{ 339-U1387B- } \\
\hline $1 \mathrm{H}-1,2.5$ & 0.025 & 0.025 & 0 & 26.67 \\
\hline $1 \mathrm{H}-1,5$ & 0.050 & 0.050 & 0 & 30.67 \\
\hline $1 \mathrm{H}-1,7.5$ & 0.075 & 0.075 & 0 & 31.00 \\
\hline $1 \mathrm{H}-1,10$ & 0.100 & 0.100 & 0 & 31.00 \\
\hline $1 \mathrm{H}-1,12.5$ & 0.125 & 0.125 & 0 & 31.67 \\
\hline $1 \mathrm{H}-1,15$ & 0.150 & 0.150 & 0 & 31.67 \\
\hline $1 \mathrm{H}-1,17.5$ & 0.175 & 0.175 & 0 & 31.67 \\
\hline $1 \mathrm{H}-1,20$ & 0.200 & 0.200 & 0 & 31.33 \\
\hline $1 \mathrm{H}-1,22.5$ & 0.225 & 0.225 & 0 & 31.00 \\
\hline $1 \mathrm{H}-1,25$ & 0.250 & 0.250 & 0 & 30.33 \\
\hline $1 \mathrm{H}-1,27.5$ & 0.275 & 0.275 & 0 & 30.33 \\
\hline $1 \mathrm{H}-1,30$ & 0.300 & 0.300 & 0 & 31.33 \\
\hline $1 \mathrm{H}-1,32.5$ & 0.325 & 0.325 & 0 & 33.67 \\
\hline $1 \mathrm{H}-1,35$ & 0.350 & 0.350 & 0 & 34.33 \\
\hline $1 \mathrm{H}-1,37.5$ & 0.375 & 0.375 & 0 & 34.67 \\
\hline $1 \mathrm{H}-1,40$ & 0.400 & 0.400 & 0 & 34.67 \\
\hline $1 \mathrm{H}-1,42.5$ & 0.425 & 0.425 & 0 & 35.33 \\
\hline $1 \mathrm{H}-1,45$ & 0.450 & 0.450 & 0 & 35.67 \\
\hline $1 \mathrm{H}-1,47.5$ & 0.475 & 0.475 & 0 & 36.00 \\
\hline $1 \mathrm{H}-1,50$ & 0.500 & 0.500 & 0 & 35.67 \\
\hline $1 \mathrm{H}-1,52.5$ & 0.525 & 0.525 & 0 & 36.00 \\
\hline $1 \mathrm{H}-1,55$ & 0.550 & 0.550 & 0 & 36.67 \\
\hline $1 \mathrm{H}-1,57.5$ & 0.575 & 0.575 & 0 & 37.67 \\
\hline $1 \mathrm{H}-1,60$ & 0.600 & 0.600 & 0 & 38.33 \\
\hline $1 \mathrm{H}-1,62.5$ & 0.625 & 0.625 & 0 & 38.33 \\
\hline $1 \mathrm{H}-1,65$ & 0.650 & 0.650 & 0 & 38.00 \\
\hline $1 \mathrm{H}-1,67.5$ & 0.675 & 0.675 & 0 & 38.67 \\
\hline $1 \mathrm{H}-1,70$ & 0.700 & 0.700 & 0 & 39.00 \\
\hline $1 \mathrm{H}-1,72.5$ & 0.725 & 0.725 & 0 & 39.33 \\
\hline $1 \mathrm{H}-1,75$ & 0.750 & 0.750 & 0 & 38.67 \\
\hline $1 \mathrm{H}-1,77.5$ & 0.775 & 0.775 & 0 & 37.67 \\
\hline $1 \mathrm{H}-1,80$ & 0.800 & 0.800 & 0 & 36.33 \\
\hline $1 \mathrm{H}-1,82.5$ & 0.825 & 0.825 & 0 & 36.33 \\
\hline $1 \mathrm{H}-1,85$ & 0.850 & 0.850 & 0 & 36.00 \\
\hline $1 \mathrm{H}-1,87.5$ & 0.875 & 0.875 & 0 & 35.33 \\
\hline $1 \mathrm{H}-1,90$ & 0.900 & 0.900 & 0 & 35.00 \\
\hline $1 \mathrm{H}-1,92.5$ & 0.925 & 0.925 & 0 & 34.33 \\
\hline $1 \mathrm{H}-1,95$ & 0.950 & 0.950 & 0 & 34.00 \\
\hline $1 \mathrm{H}-1,97.5$ & 0.975 & 0.975 & 0 & 33.67 \\
\hline $1 \mathrm{H}-1,100$ & 1.000 & 1.000 & 0 & 33.67 \\
\hline $1 \mathrm{H}-1,102.5$ & 1.025 & 1.025 & 0 & 34.00 \\
\hline $1 \mathrm{H}-1,105$ & 1.050 & 1.050 & 0 & 34.00 \\
\hline $1 \mathrm{H}-1,107.5$ & 1.075 & 1.075 & 0 & 33.33 \\
\hline $1 \mathrm{H}-1,110$ & 1.100 & 1.100 & 0 & 33.33 \\
\hline $1 \mathrm{H}-1,112.5$ & 1.125 & 1.125 & 0 & 33.67 \\
\hline $1 \mathrm{H}-1,115$ & 1.150 & 1.150 & 0 & 33.33 \\
\hline $1 \mathrm{H}-1,117.5$ & 1.175 & 1.175 & 0 & 34.33 \\
\hline $1 \mathrm{H}-1,120$ & 1.200 & 1.200 & 0 & 34.33 \\
\hline $1 \mathrm{H}-1,122.5$ & 1.225 & 1.225 & 0 & 35.00 \\
\hline $1 \mathrm{H}-1,125$ & 1.250 & 1.250 & 0 & 35.00 \\
\hline $1 \mathrm{H}-1,127.5$ & 1.275 & 1.275 & 0 & 35.67 \\
\hline $1 \mathrm{H}-1,130$ & 1.300 & 1.300 & 0 & 36.00 \\
\hline $1 \mathrm{H}-1,132.5$ & 1.325 & 1.325 & 0 & 36.33 \\
\hline $1 \mathrm{H}-1,135$ & 1.350 & 1.350 & 0 & 36.33 \\
\hline $1 \mathrm{H}-1,137.5$ & 1.375 & 1.375 & 0 & 36.67 \\
\hline $1 \mathrm{H}-1,140$ & 1.400 & 1.400 & 0 & 36.67 \\
\hline $1 \mathrm{H}-1,142.5$ & 1.425 & 1.425 & 0 & 36.67 \\
\hline $1 \mathrm{H}-1,145$ & 1.450 & 1.450 & 0 & 36.00 \\
\hline $1 \mathrm{H}-1,147.5$ & 1.475 & 1.475 & 0 & 34.33 \\
\hline
\end{tabular}

Only a portion of this table appears here. The complete table is available in ASCII. 
Table T24. Natural gamma radiation (NGR) splice, Site U1387.

\begin{tabular}{|c|c|c|c|c|}
\hline \multirow{2}{*}{$\begin{array}{l}\text { Core, section, } \\
\text { interval }(\mathrm{cm})\end{array}$} & \multicolumn{2}{|c|}{ Depth } & \multirow[b]{2}{*}{ Offset (m) } & \multirow[b]{2}{*}{ NGR (cps) } \\
\hline & (mbsf) & $(\mathrm{mcd})$ & & \\
\hline \multicolumn{5}{|l|}{ 339-U1387B- } \\
\hline $1 \mathrm{H}-1,10$ & 0.100 & 0.100 & 0.000 & 22.28 \\
\hline $1 \mathrm{H}-1,30$ & 0.300 & 0.300 & 0.000 & 25.45 \\
\hline $1 \mathrm{H}-1,50$ & 0.500 & 0.500 & 0.000 & 27.30 \\
\hline $1 \mathrm{H}-1,70$ & 0.700 & 0.700 & 0.000 & 27.79 \\
\hline $1 \mathrm{H}-1,90$ & 0.900 & 0.900 & 0.000 & 27.17 \\
\hline $1 \mathrm{H}-1,110$ & 1.100 & 1.100 & 0.000 & 27.09 \\
\hline $1 \mathrm{H}-1,130$ & 1.300 & 1.300 & 0.000 & 27.99 \\
\hline $1 \mathrm{H}-2,10$ & 1.600 & 1.600 & 0.000 & 29.53 \\
\hline $1 \mathrm{H}-2,30$ & 1.800 & 1.800 & 0.000 & 32.39 \\
\hline $1 \mathrm{H}-2,50$ & 2.000 & 2.000 & 0.000 & 33.77 \\
\hline $1 \mathrm{H}-2,70$ & 2.200 & 2.200 & 0.000 & 32.79 \\
\hline $1 \mathrm{H}-2,90$ & 2.400 & 2.400 & 0.000 & 35.71 \\
\hline $1 \mathrm{H}-2,110$ & 2.600 & 2.600 & 0.000 & 38.08 \\
\hline $1 \mathrm{H}-2,130$ & 2.800 & 2.800 & 0.000 & 38.41 \\
\hline $1 \mathrm{H}-3,10$ & 3.100 & 3.100 & 0.000 & 38.61 \\
\hline $1 \mathrm{H}-3,30$ & 3.300 & 3.300 & 0.000 & 39.85 \\
\hline $1 \mathrm{H}-3,50$ & 3.500 & 3.500 & 0.000 & 41.25 \\
\hline $1 \mathrm{H}-3,70$ & 3.700 & 3.700 & 0.000 & 39.89 \\
\hline $1 \mathrm{H}-3,90$ & 3.900 & 3.900 & 0.000 & 40.01 \\
\hline $1 \mathrm{H}-3,110$ & 4.100 & 4.100 & 0.000 & 40.10 \\
\hline $1 \mathrm{H}-3,130$ & 4.300 & 4.300 & 0.000 & 40.04 \\
\hline $1 \mathrm{H}-4,10$ & 4.600 & 4.600 & 0.000 & 39.63 \\
\hline $1 \mathrm{H}-4,30$ & 4.800 & 4.800 & 0.000 & 41.28 \\
\hline $1 \mathrm{H}-4,50$ & 5.000 & 5.000 & 0.000 & 40.84 \\
\hline $1 \mathrm{H}-4,70$ & 5.200 & 5.200 & 0.000 & 41.54 \\
\hline $1 \mathrm{H}-4,90$ & 5.400 & 5.400 & 0.000 & 41.73 \\
\hline $1 \mathrm{H}-4,110$ & 5.600 & 5.600 & 0.000 & 43.25 \\
\hline $1 \mathrm{H}-4,130$ & 5.800 & 5.800 & 0.000 & 41.07 \\
\hline $1 \mathrm{H}-5,10$ & 6.100 & 6.100 & 0.000 & 40.09 \\
\hline $1 \mathrm{H}-5,30$ & 6.300 & 6.300 & 0.000 & 40.73 \\
\hline $1 \mathrm{H}-5,50$ & 6.500 & 6.500 & 0.000 & 41.70 \\
\hline $1 \mathrm{H}-5,70$ & 6.700 & 6.700 & 0.000 & 41.67 \\
\hline $1 \mathrm{H}-5,90$ & 6.900 & 6.900 & 0.000 & 41.90 \\
\hline $1 \mathrm{H}-5,110$ & 7.100 & 7.100 & 0.000 & 44.34 \\
\hline $1 \mathrm{H}-5,130$ & 7.300 & 7.300 & 0.000 & 40.99 \\
\hline $1 \mathrm{H}-5,48.7$ & 7.987 & 7.987 & 0.000 & 40.99 \\
\hline $2 \mathrm{H}-2,62.6$ & 7.127 & 7.987 & 0.860 & 40.99 \\
\hline $2 \mathrm{H}-2,62.6$ & 7.127 & 7.987 & 0.860 & 43.04 \\
\hline $2 \mathrm{H}-2,70$ & 7.200 & 8.060 & 0.860 & 42.80 \\
\hline $2 \mathrm{H}-2,90$ & 7.400 & 8.260 & 0.860 & 41.26 \\
\hline $2 \mathrm{H}-2,110$ & 7.600 & 8.460 & 0.860 & 41.04 \\
\hline $2 \mathrm{H}-2,130$ & 7.800 & 8.660 & 0.860 & 38.94 \\
\hline $2 \mathrm{H}-3,10$ & 8.100 & 8.960 & 0.860 & 43.61 \\
\hline $2 \mathrm{H}-3,30$ & 8.300 & 9.160 & 0.860 & 43.98 \\
\hline $2 \mathrm{H}-3,50$ & 8.500 & 9.360 & 0.860 & 44.98 \\
\hline $2 \mathrm{H}-3,70$ & 8.700 & 9.560 & 0.860 & 43.86 \\
\hline $2 \mathrm{H}-3,90$ & 8.900 & 9.760 & 0.860 & 41.65 \\
\hline $2 \mathrm{H}-3,110$ & 9.100 & 9.960 & 0.860 & 44.68 \\
\hline $2 \mathrm{H}-3,130$ & 9.300 & 10.160 & 0.860 & 42.90 \\
\hline $2 \mathrm{H}-4,10$ & 9.600 & 10.460 & 0.860 & 41.08 \\
\hline $2 \mathrm{H}-4,30$ & 9.800 & 10.660 & 0.860 & 43.74 \\
\hline $2 \mathrm{H}-4,46.1$ & 9.962 & 10.822 & 0.860 & 42.79 \\
\hline $2 \mathrm{H}-2,84.2$ & 11.242 & 10.822 & -0.420 & 42.79 \\
\hline $2 \mathrm{H}-2,84.2$ & 11.242 & 10.822 & -0.420 & 41.76 \\
\hline $2 \mathrm{H}-2,90$ & 11.300 & 10.880 & -0.420 & 41.40 \\
\hline $2 \mathrm{H}-2,110$ & 11.500 & 11.080 & -0.420 & 43.01 \\
\hline $2 \mathrm{H}-2,130$ & 11.700 & 11.280 & -0.420 & 42.81 \\
\hline $2 \mathrm{H}-3,10$ & 12.000 & 11.580 & -0.420 & 41.69 \\
\hline $2 \mathrm{H}-3,30$ & 12.200 & 11.780 & -0.420 & 41.98 \\
\hline $2 \mathrm{H}-3,50$ & 12.400 & 11.980 & -0.420 & 43.00 \\
\hline
\end{tabular}

Only a portion of this table appears here. The complete table is available in ASCII. 